\title{
Siting Study for the Remote-Handled Low- Level Waste Disposal Project
}

\author{
Lisa Harvego \\ Joan Connolly \\ Lance Peterson \\ Brennon Orr \\ Bob Starr
}

October 2010

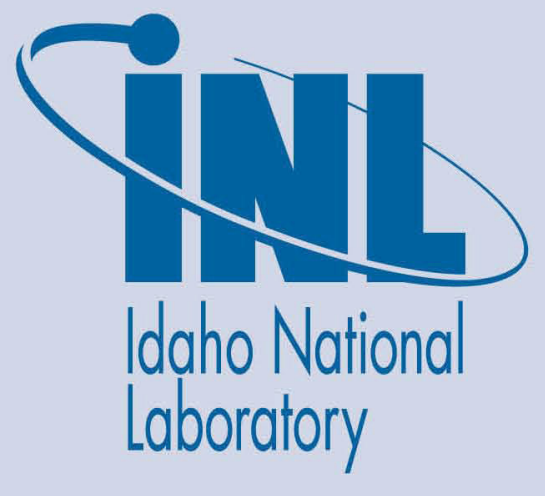

The INL is a U.S. Department of Energy National Laboratory operated by Battelle Energy Alliance 
INL/EXT-07-12902

Rev. 2

\title{
Siting Study for the Remote-Handled Low-Level Waste Disposal Project
}

\author{
Lisa Harvego \\ Joan Connolly ${ }^{1}$ \\ Lance Peterson ${ }^{1}$ \\ Brennon Orr ${ }^{1}$ \\ Bob Starr ${ }^{1}$ \\ ${ }^{1}$ North Wind, Inc.
}

October 2010

\begin{abstract}
Idaho National Laboratory
Idaho Falls, Idaho 83415
\end{abstract}

http://www.inl.gov

Prepared for the

U.S. Department of Energy

Office of Nuclear Energy

Under DOE Idaho Operations Office

Contract DE-AC07-05ID14517 



\section{ABSTRACT}

The U.S. Department of Energy has identified a mission need for continued disposal capacity for remote-handled low-level waste (LLW) generated at the Idaho National Laboratory (INL). An alternatives analysis that was conducted to evaluate strategies to achieve this mission need identified two broad options for disposal of INL generated remote-handled LLW: (1) offsite disposal and (2) onsite disposal. The purpose of this study is to identify candidate sites or locations within INL boundaries for the alternative of an onsite remote-handled LLW disposal facility and recommend the highest-ranked locations for consideration in the National Environmental Policy Act process. The study implements an evaluation based on consideration of five key elements: (1) regulations, (2) key assumptions, (3) conceptual design, (4) facility performance, and (5) previous INL siting study criteria, and uses a five-step process to identify, screen, evaluate, score, and rank 34 separate sites located across INL. The result of the evaluation is identification of two recommended alternative locations for siting an onsite remote-handled LLW disposal facility. The two alternative locations that best meet the evaluation criteria are (1) near the Advanced Test Reactor Complex and (2) west of the Idaho Comprehensive Environmental Response, Compensation, and Liability Act Disposal Facility. 


\section{EXECUTIVE SUMMARY}

The U.S. Department of Energy has identified a mission need for continued disposal capacity for remote-handled low-level waste (LLW) generated at the Idaho National Laboratory (INL). The existing onsite disposal facility at the INL Radioactive Waste Management Complex will not be available after 2017, which forms the basis for the U.S. Department of Energy mission need to select a new alternative for disposal of INL-generated remote-handled LLW. An alternatives analysis that was conducted to evaluate strategies to achieve this mission need identified two broad options for disposal of INL generated remote-handled LLW: (1) offsite disposal and (2) onsite disposal. This siting study was conducted to support evaluation of the onsite disposal alternative. The study identifies candidate locations at INL and evaluates them against technical and programmatic objectives for remote-handled LLW disposal.

The purpose of this document is to present the evaluation that identifies candidate site locations or areas within INL boundaries for further consideration in the National Environmental Policy Act process. Five key areas are identified as primary contributors to the synthesis of information and requirements used for development of a comprehensive set of siting criteria. The key areas are as follows:

\section{(1) Regulations}

(2) Key assumptions

(3) Conceptual design

(4) Facility performance

(5) Previous siting study criteria.

The evaluation process identifies regulations, codes, and directives that may be applicable to siting a facility or that are useful in determining specific evaluation criteria. Siting criteria derived from the five areas address requirements that are important during the operational life of the facility and requirements that give consideration to post-closure performance over longer timeframes. A thorough analysis of the five key areas is provided in Appendix A. 
The Remote-Handled LLW Disposal Project evaluation process implements a methodology derived from the strategies used in previous siting studies. In summary, "Must" (critical features that are needed) and "Want" (important features that may enhance facility performance or reduce its effects on the environment) criteria were established and weighted based on relative significance. The five steps of the process used for this evaluation are as follows:

(1) Identify criteria (both "Must" and "Want")

(2) Identify candidate sites

(3) Apply "Must" screening criteria to all candidate sites

(4) Apply "Want" criteria to sites passing the "Must" screening

(5) Rank candidate sites and recommend the most suitable site(s).

Appendix B presents the analysis used to select the "Must" and "Want" criteria. A total of 53 criteria were identified and evaluated for use on this project. The criteria evaluation resulted in identification of four "Must" criteria and twenty-one "Want" criteria to be used in this siting evaluation.

Appendix $\mathrm{C}$ presents the assessment of the initial set of 34 candidate sites against the established criteria. Two sites are recommended for consideration in the National Environmental Policy Act process. A site walk-down was conducted at the three highest-ranked sites to review site-specific conditions and verify that individual sites were appropriately recommended for further consideration through the National Environmental Policy Act process. The two locations that best meet the evaluation criteria are (1) near the Advanced Test Reactor and (2) west of the Idaho Comprehensive Environmental Response, Compensation, and Liability Act Disposal Facility. 


\section{CONTENTS}

ABSTRACT.

EXECUTIVE SUMMARY

ACRONYMS ix

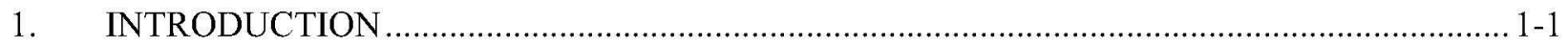

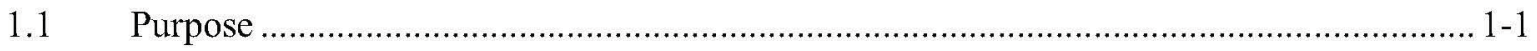

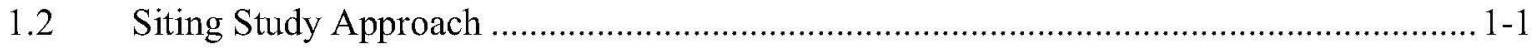

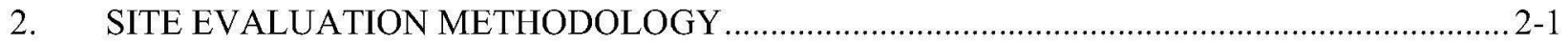

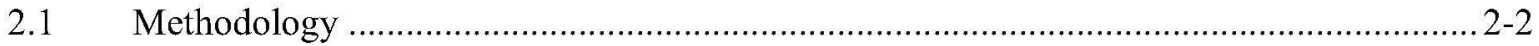

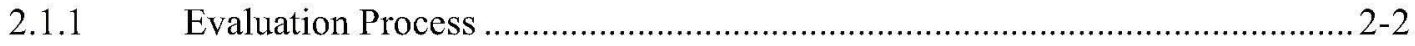

2.1.2 Identification of Potential Siting Criteria ............................................... 2-3

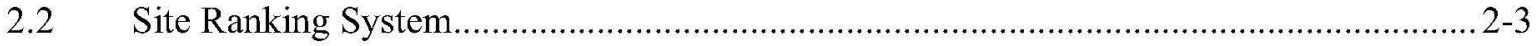

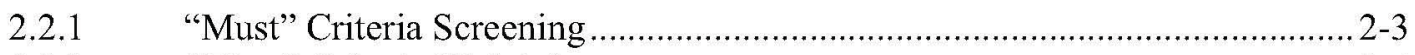

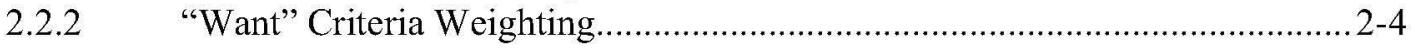

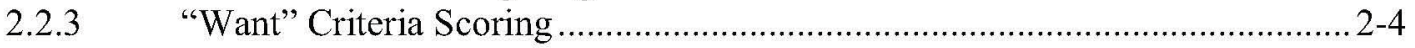

3. REMOTE-HANDLED LOW-LEVEL WASTE DISPOSAL SITE EVALUATION ....................3-1

3.1 Site Evaluation Criteria Identification .........................................................................

3.1.1 Identify "Must" Site Evaluation Criteria .................................................. 3-1

3.1.2 Identify "Want" Site Evaluation Criteria ...................................................... 3-2

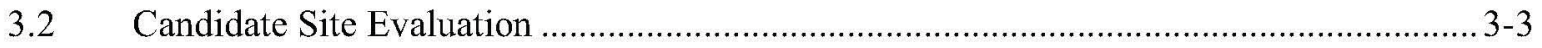

3.2.1 Identify Candidate Sites .......................................................................

3.2.2 Develop Weighting and Scoring Factors.................................................. 3-6

3.2.3 Screen Against "Must" Criteria...................................................................... 3-8

3.2.4 Evaluate Against "Want" Criteria ….......................................................... 3-10

3.3 Remote-Handled Low-Level Waste Disposal Project Site Evaluation Results............... 3-13

3.3.1 Site 5, Near the Advanced Test Reactor Complex ...................................... 3-14

3.3.2 Site 34, Southwest of the Idaho CERCLA Disposal Facility …….................. 3-14

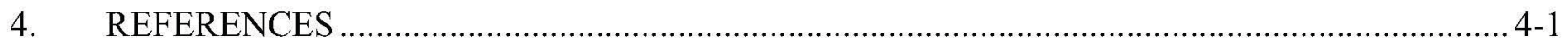




\section{APPENDIXES}

Appendix A, Site Evaluation Requirements ....................................................................................... A-1

Appendix B, Identification of Site Evaluation Criteria................................................................... B-1

Appendix C, Application of Site Evaluation Criteria .............................................................................. C-1

FIGURES

1-1. The overall process for siting, planning, and constructing a remote-handled low-level

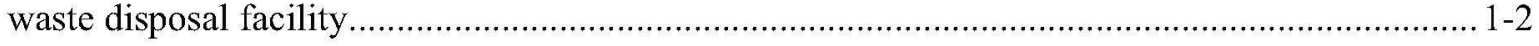

3-1. Location of the 34 candidate sites within the Idaho National Laboratory boundary......................3-4

3-2. Idaho National Laboratory map showing "Must" criteria data ................................................ 3-11

3-3. Distribution of remote-handled low-level waste candidate site scores.................................... 3-13

3-4. Candidate Site 5, near the Advanced Test Reactor Complex ................................................ 3-15

3-5. Candidate Site 34, near the Idaho CERCLA Disposal Facility .............................................. 3-16

\section{TABLES}

1-1. Summary of key evaluation areas for the identification of site selection criteria......................... 1-3

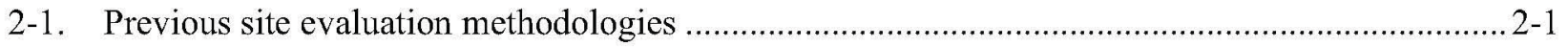

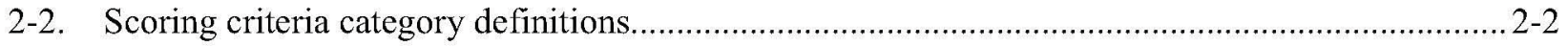

3-1. Remote-handled low-level waste disposal facility "Want" criteria ............................................... 3-2

3-2. Candidate site locations for an onsite remote-handled low-level waste disposal facility...............3-5

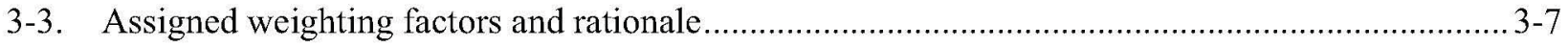

3-4. Criterion scoring definitions, $1=$ Low, 3 = Medium, 5 = High ............................................... 3-9

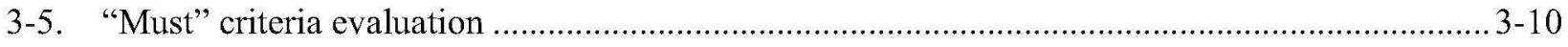

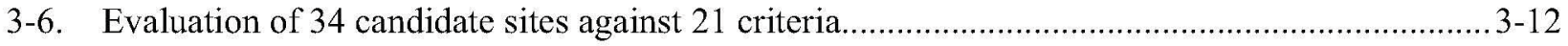




\section{ACRONYMS}

ATR Advanced Test Reactor

CERCLA Comprehensive Environmental Response, Compensation, and Liability Act

DOE Department of Energy

ICDF Idaho CERCLA Disposal Facility

INL Idaho National Laboratory

INTEC Idaho Nuclear Technology and Engineering Center

LLW low-level waste

MLLW mixed low-level waste

NEPA National Environmental Policy Act

NRC Nuclear Regulatory Commission

RWMC Radioactive Waste Management Complex

USGS United States Geological Survey 


\section{Siting Study for the Remote-Handled Low-Level Waste Disposal Project}

\section{INTRODUCTION}

The U.S. Department of Energy (DOE) has identified a mission need for disposal of remote-handled low-level waste (LLW) consisting of activated metals and ion-exchange resins generated at the Idaho National Laboratory (INL). The existing disposal facility at INL's Radioactive Waste Management Complex (RWMC) will not be available after 2017, and a new disposal location must be selected. An alternatives analysis that was conducted to evaluate strategies to achieve this mission need identified two broad options for disposal of INL-generated remote-handled LLW: (1) offsite disposal (most likely at the Nevada Test Site), or (2) onsite at a newly constructed facility. In support of the onsite disposal alternative, this siting study was conducted to identify and recommend a limited number of onsite locations for remote-handled LLW disposal. The recommended sites will be subjected to further evaluation through the National Environmental Policy Act (NEPA) process. Figure 1-1 illustrates the overall process for siting, planning, and constructing remote-handled LLW disposal capacity pursuant to DOE Order 413.3B, "Program and Project Management for Acquisition of Capital Assets."

\subsection{Purpose}

The purpose of this document is to identify candidate site locations or areas within INL boundaries for an onsite remote-handled LLW disposal facility and to recommend one or more sites for consideration in the NEPA process. This evaluation identifies regulations, codes, and procedures that may be applicable to siting such a facility or that are useful in determining specific evaluation criteria. In addition, extensive use was made of previous siting studies conducted over the past 19 years to take advantage of the available INL knowledge base that has been compiled over 50 years of INL operations.

\subsection{Siting Study Approach}

Previous INL siting studies provide examples of various methods used for development and application of evaluation criteria and ranking strategies for site selection. Although these studies were conducted to evaluate sites for different types of facilities, they each identify numerous onsite candidate sites with a range of individual characteristics. Based on the analysis of previous siting studies, five key areas emerge as the primary contributors to development of site evaluation criteria. The criteria are developed from the synthesis of information and requirements from the following areas:

1. Regulations

2. Key assumptions

3. Conceptual design

4. Facility performance

5. Previous siting study criteria. 


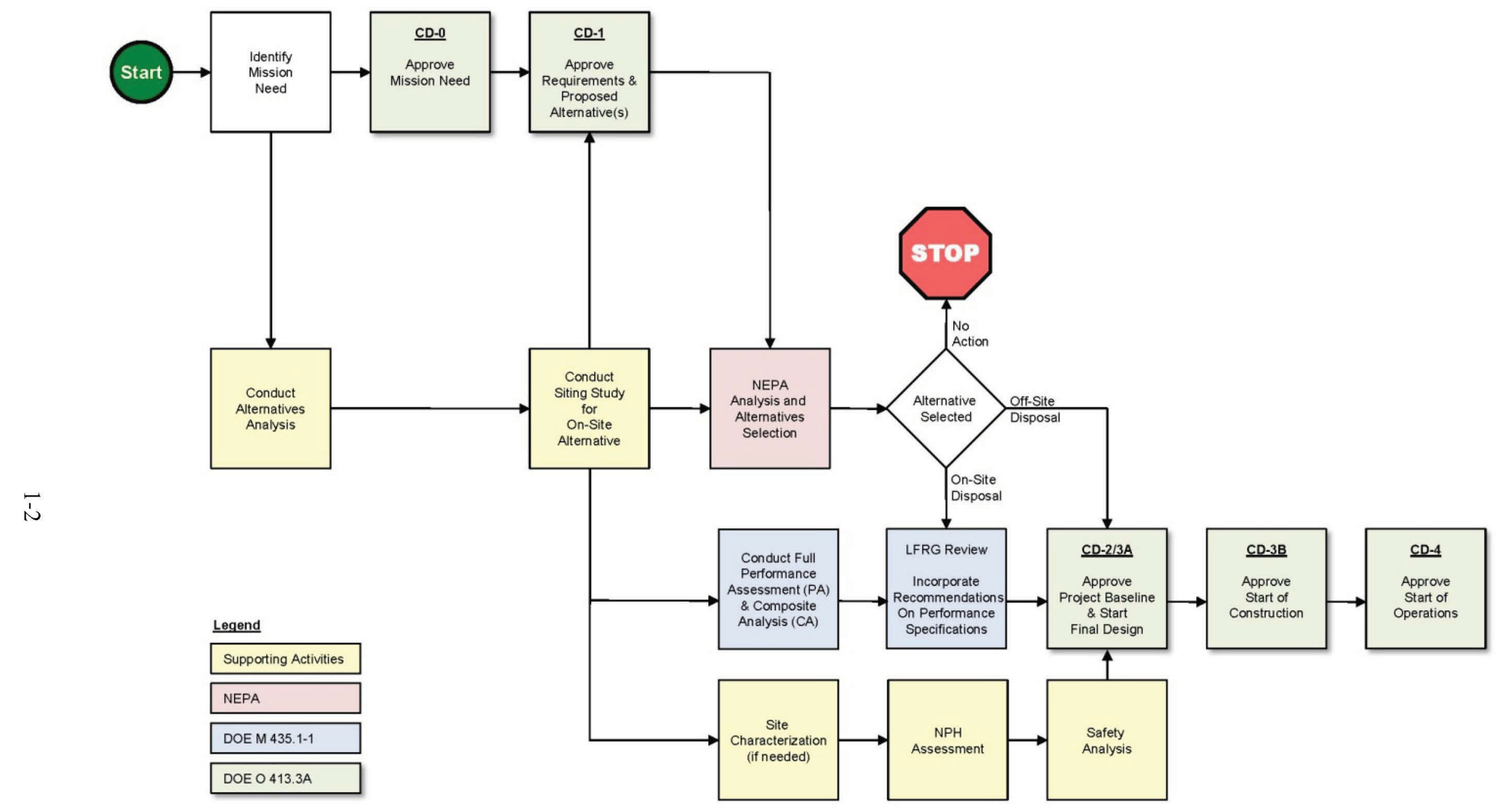

Figure 1-1. The overall process for siting, planning, and constructing a remote-handled low-level waste disposal facility. 
The approach used in this report begins with a review of each of the key evaluation areas to identify critical requirements or important facility performance features that may be used to set criteria for site evaluation and ranking (see Appendix A for the detailed analysis). The evaluation areas are interrelated, leading to a criteria selection process that is iterative in nature and results in identification of criteria that draw from both requirements and facility performance. Section 1 provides a summary description of "Must" criteria and "Want" criteria.

The first key evaluation area (regulations) sets the regulatory framework for siting a LLW disposal facility to meet DOE requirements. The second and third areas (key assumptions and conceptual design) include facility-specific features related to type and volume of waste, geometry of the disposal system (vaults), and facility needs in terms of utilities and support infrastructure. The fourth area (facility performance) draws requirements from regulations and DOE orders and considers, in large part, the physical setting of each location (i.e., geology, hydrology, natural resources, and natural phenomena hazards). The fifth area (previous siting study criteria) provides examples of evaluation criteria developed during the siting of other facilities at INL. The previous studies also identify and provide characterization data for a number of sites across INL that can be considered as candidate locations for a LLW disposal facility. Appendix A provides a detailed analysis of each of the five key site evaluation areas. Table 1-1 summarizes the resultant drivers drawn from review of the five areas.

The approach presented in this report combines the techniques that worked best from each of the studies and simplifies them into a concise sequential process, which includes identifying criteria, identifying sites, applying criteria, and ranking sites. Section 1 presents the evaluation methodology for the onsite Remote-Handled LLW Disposal Project siting study, and Section 1 describes implementation of the process for scoring and ranking sites to identify the most promising candidate sites for location of the facility.

Table 1-1. Summary of key evaluation areas for the identification of site selection criteria.

Key Site

Evaluation Areas

1. Regulations

2. Key assumptions
Contribution to Development of Selection Criteria

- $\quad$ DOE Orders 435.1, 430.1B, and 420.1 (with manuals, guides, and standards)

- 10 Code of Federal Regulations 61.40 and 61.50 (not required for a DOE facility but useful for criteria development)

- Applicable federal laws, executive orders, and implementing regulations (Clean Air Act; Endangered Species Act; and Historical, Tribal, and Cultural Resources).

- Waste generation rate of approximately $3,108 \mathrm{ft}^{3}$ per year

- Waste type (remote-handled LLW activated metals and ion-exchange resins)

- Limitations on waste characteristics resulting from the performance assessment will be no more restrictive than those for the existing onsite remote-handled LLW disposal facility (contributes to conceptual facility design requirements that impact criteria selection)

- A new documented safety analysis and performance assessment will be required for the facility (contributes to a need for evaluation of current site data that impact criteria selection) 
Table 1-1. (continued).

Key Site

Evaluation Areas

Contribution to Development of Selection Criteria

- Facility size requirements (e.g., desired area of 5 acres and surficial soils at a depth of 29 to $39 \mathrm{ft}$ )

- Utilities (beneficial if power and water are available, but not mandatory)

3. Conceptual design - Haul route and access roads (e.g., safe transport of anticipated loads and turning radius)

- Performance Category 1 (seismic design criterion per DOE-STD-11892008 and the International Building Code)

- Protection of the public (specifies three dose limit requirements)

- Facility requirements (e.g., access, power, water resources, and surface features)

4. Facility performance

- Radionuclide Performance Assessment (specifies geological and hydrological conditions that attenuate radionuclide migration and intruder assessments)

- Site characteristics must be such that acceptable results can be obtained for the Natural Phenomena Hazards Assessment (performance category-specific seismic and flooding requirements for 100,500, and 1,000 -year events, with consideration of 10,000-year events)

- Examples of "Must" and "Want" criteria

5. Previous siting studies

- Identification of candidate sites (34 candidate sites identified)

- Evaluation methodology (three separate evaluation strategies identified). 


\section{SITE EVALUATION METHODOLOGY}

Selecting an appropriate evaluation methodology to apply to candidate sites for the Remote-Handled LLW Disposal Project ensures that facility-specific critical and important performance factors are considered in light of both the operational lifetime and post-closure timeframe. The evaluation can be qualitative or quantitative and necessarily involves a significant element of professional judgment on the part of experts in the technical disciplines required to support the site evaluation process. Because of the significant amount of information produced during the development of past siting studies, this report is able to draw upon the strategies developed and implemented for 34 previously identified candidate sites. Each of the previous studies used a different methodology to evaluate candidate sites. Appendix A, Section A-4, provides a summary analysis of each of the four previous studies. Table 2-1 identifies the previous siting study documents by document title, reference identifier, facility type, and the methodology used in the evaluation process.

Table 2-1. Previous site evaluation methodologies.

\begin{tabular}{|c|c|c|}
\hline Previous Study/Reference & Facility Type/Purpose & $\begin{array}{c}\text { Evaluation } \\
\text { Methodology }\end{array}$ \\
\hline $\begin{array}{l}\text { Preliminary Evaluation of Potential Locations on } \\
\text { the Idaho National Engineering and } \\
\text { Environmental Laboratory for a High-Level } \\
\text { Waste Treatment and Interim Storage Facility } \\
\text { and a Low-Level Waste Landfill (Holdren et al. } \\
\text { 1997) }\end{array}$ & $\begin{array}{l}\text { High-level waste treatment and } \\
\text { interim storage facility and LLW } \\
\text { landfill }\end{array}$ & $\begin{array}{l}\text { Professional } \\
\text { judgment }\end{array}$ \\
\hline $\begin{array}{l}\text { Site Selection Report for the New Production } \\
\text { Reactor (NPR) at the Idaho National } \\
\text { Engineering Laboratory } \\
\text { (Spry et al. 1989) }\end{array}$ & New production reactor & Kepner-Tregoe \\
\hline $\begin{array}{l}\text { Preliminary Siting Activities for New Waste } \\
\text { Handling Facilities at the Idaho National } \\
\text { Engineering Laboratory (Taylor et al. 1994) }\end{array}$ & $\begin{array}{l}\text { New waste handling facilities at } \\
\text { INL, includes mixed low-level } \\
\text { waste (MLLW) treatment and } \\
\text { disposal }\end{array}$ & $\begin{array}{l}\text { Professional } \\
\text { judgment }\end{array}$ \\
\hline $\begin{array}{l}\text { Final Record of Decision Idaho Nuclear } \\
\text { Technology and Engineering Center Operable } \\
\text { Unit 3-13 (DOE-ID 1999) }\end{array}$ & $\begin{array}{l}\text { Idaho Comprehensive } \\
\text { Environmental Response, } \\
\text { Compensation, and Liability Act } \\
\text { (CERCLA) Disposal Facility } \\
\text { (ICDF) for MLLW }\end{array}$ & $\begin{array}{l}\text { Analytic } \\
\text { hierarchy } \\
\text { process }\end{array}$ \\
\hline
\end{tabular}

Together, these four siting studies provided an in-depth assessment of geological, hydrological, land use, and natural resource characteristics for the 34 candidate sites. Integrating these approaches into a simplified semi-quantitative methodology takes advantage of the existing knowledge while at the same time overcoming some of the shortfalls of any individual approach. The remainder of this section describes the methodology used to screen candidate sites for the Remote-Handled LLW Disposal Project to eliminate the locations deemed unsuitable and to identify locations warranting further evaluation. 


\subsection{Methodology}

Applicable regulations (i.e., DOE orders and federal, state, and local laws and regulations), key assumptions, design objectives, and performance objectives form the basis or starting point of the Remote-Handled LLW Disposal Project siting study and recommendation process. Each of these four areas provides criteria that may be considered either critical or important. Historically, siting studies have focused on regulatory language that identifies criteria that "Must" be met, those that "Should" be met, or characteristics to be "Avoided."

The most common language used in siting study reports to separate these two groups of criteria are "Must" for the critical features and "Want" for the important features that are "desired" or "to be avoided." Definitions for these two categories of criteria are provided in Table 2-2, with annotations to clarify their usage in this siting study.

Table 2-2. Scoring criteria category definitions.

Criterion

Definition

"Must" A critical site characteristic; the location may not be suitable if not met. DOE Order 435.1 allows the possibility of engineered solutions to "Must" criteria that are not initially met (e.g., location within a 500-year floodplain may be mitigated by engineered barriers).

"Want" An important site characteristic; location may have desirable characteristics (e.g., thicker fine grain interbed matrix provides better attenuation of radionuclides) or undesirable characteristics (e.g., presence of perched water may provide a migration pathway).

The remainder of this section outlines a five-step methodology used to evaluate candidate sites and further describes the application of "Must" and "Want" criteria. This section concludes with a description of the scoring system used to identify the most suitable candidate sites for the location of a remote-handled LLW disposal facility.

\subsubsection{Evaluation Process}

While a facility site evaluation process considers many detailed and often complex criteria, it can be refined into an efficient five-step process that analyzes available data and information in a logical sequence. As presented here, the process makes extensive use of previous siting studies to take full advantage of criteria development and decision analyses or ranking strategies that have proven successful in the past. The five-step process is as follows:

1. Identify criteria (both "Must" and "Want")

2. Identify candidate sites

3. Apply "Must" screening criteria to all candidate sites

4. Apply "Want" criteria to sites passing the "Must" screening

5. Rank candidate sites and recommend the most suitable site(s). 
This process is not formally recommended or driven by regulatory guidance but is presented here as a method to quickly and clearly assess existing information, screen a number of candidate sites, and make a recommendation of the most promising candidate sites for further consideration within the NEPA process.

\subsubsection{Identification of Potential Siting Criteria}

The site evaluation process begins with identification of a broad range of criteria appropriate for a LLW disposal facility and is followed by review and selection of those criteria suitable for this siting study. Onsite and offsite locations for a new remote-handled LLW disposal facility were considered in the Low-Level Waste Disposal Alternatives Analysis Report (INL 2009). For the purposes of this onsite disposal siting study, INL is considered to be the regional location of all potential sites. With the regional location determined, four previous INL siting studies were used to compile an extensive list of criteria. Additional criteria, drawn primarily from regulations or DOE orders, were added for completeness.

An important aspect of the criteria selection process is consideration of site features that are applicable to the operational timeframe for the facility and for the post-closure timeframe. For example, operational timeframe features may include surficial sediment thickness (important for design, construction, and operation) and location of sensitive species or habitat (important for physical location of the facility). Post-closure features, on the other hand, consider longer timeframes (e.g., 100, 500, and 1,000 years) typically associated with radionuclide migration and seismic, flooding, volcanic, or other natural hazards phenomena. While not required by regulation or DOE order, this siting study does include the potential for even longer recurrence interval events (e.g., 10,000 years) in the development of weighting and scoring factors.

Each "Must" criterion compiled from previous studies, regulations, or orders was screened to determine whether it was appropriate for this Remote-Handled LLW Disposal Project siting study. The objective was to reduce the original set to focus on just those criteria that represent the critical features needed for screening candidate sites. Criteria considered for the "Must" category, but not selected, were screened for use in the "Want" category. A similar process was used for compiling and screening "Want" criteria. This screening process is presented in detail in Appendix B and is summarized in Section 1.

\subsection{Site Ranking System}

A common element in all of the siting studies reviewed was application of a numerical ranking system. Using a numerical ranking system is subjective in nature, making use of the professional experience of experts in the technical disciplines required to support the site evaluation process. The four studies reviewed in Appendix A have been used to create a decision analysis and ranking methodology that benefits from combined experience of over 50 professional engineers and scientists with detailed knowledge of INL site characteristics, facility design, and facility safety.

\subsection{1 “Must” Criteria Screening}

DOE Order 435.1, "Radioactive Waste Management," requires that a site "Must" be able to be characterized with respect to a number of features and allows engineered mitigation if, for example, a site is located in a floodplain. DOE Order 420.1B, "Facility Safety" (with sub-tier manuals, guides, and standards) provides a graded approach to evaluation and assessment of natural phenomena hazards based on the performance category of the facility. Consequently, the "Must" criteria developed for a remote-handled LLW disposal facility are selected to meet the performance category requirements of DOE Order 420.1B. All "Must" criteria are stated in the negative (e.g., a site "must not be located..."). If a site satisfies all "Must" criteria, it is retained for further evaluation. On the other hand, if a site fails a 
"Must" criterion, further evaluation will be appropriate only if reasonable measures can be taken to mitigate an undesirable condition (per DOE Order 435.1). For example, Holdren et al. (1997) used this approach with regard to several sites located near, but not in, the 100-year floodplain.

\subsection{2 "Want" Criteria Weighting}

Potential "Want" criteria, including those that were carried over from the "Must" screening, are assessed in detail in Appendix B. Those criteria that were determined to be applicable for screening potential facility sites are identified in Section 3.1.2. The methodology for ranking candidate sites involves assigning a weighting factor to allow relative ranking of the criteria (i.e., how important each criterion is to overall siting). The criterion importance is evaluated based on its relative impact on the design, construction, or operation/performance of a remote-handled LLW disposal facility. A five-tier scale is used to assign a weighting factor to each criterion, as follows:

- 1 = Very low

- $2=$ Low

- $\quad 3=$ Medium

- $\quad 4$ = High

- $5=$ Very high.

See Section 1 for a summary of the "Want" criteria and for the rationale used in assigning weighting factors.

\subsection{3 "Want" Criteria Scoring}

With a weighting factor assigned, each criterion must then be scored to determine how well the site satisfies all of the criteria. Again, a simple scoring approach was used where $1=$ Low, $3=$ Medium, and $5=$ High. The choice of 1,3 , or 5 was made to provide a means of spreading the possible scores over a wider range in an attempt to make groups of similar rank easier to identify. Multiplying the weighting factor with the criterion score produces a numerical value for that criterion, and summing all the criteria values for each site gives a total relative value. A high score indicates a preferential site. Section 1 describes the "Want" criteria and definitions for assigning a 1,3, or 5 score. 


\section{REMOTE-HANDLED LOW-LEVEL WASTE DISPOSAL SITE EVALUATION}

This section describes application of the five-step LLW disposal site evaluation process. Criteria drawn from applicable regulations, desired facility performance features, and previous INL siting studies are screened, and those appropriate for the remote-handled LLW disposal site evaluation process are summarized. A relative ranking system is applied to assess the suitability of each site. Sites with the highest score represent preferred locations. High-scoring sites are recommended for consideration in the NEPA process.

\subsection{Site Evaluation Criteria Identification}

Selection of site evaluation criteria begins with review of applicable regulations and is followed by identification of objectives drawn from desired facility performance features, and the conceptual design developed to meet those performance features. During the site evaluation process, not all detailed requirements are known. As a result, performance assessment objectives and conceptual design objectives, augmented by key assumptions in conjunction with regulatory requirements, provide the basis for developing site evaluation criteria. Appendix A summarizes regulations, objectives, key assumptions, and previous siting studies that were used to provide examples of criteria in actual use.

As noted previously in Section 2.1.2, the criteria identification process considers both the facility operational timeframe and the post-closure timeframe. Operational timeframe features may include surficial sediment thickness (important for design, construction, and operation) and location of sensitive species or habitat (important for physical location of the facility). Post-closure features, on the other hand, consider longer timeframes (e.g., 100, 500, and 1,000 years) typically associated with radionuclide migration and seismic, flooding, volcanic, or other natural hazards phenomena. While not required by regulation or DOE order, this siting study does include the potential for even longer recurrence interval events (e.g., 10,000 years) in the development of weighting and scoring factors.

Step 1 of the evaluation process is to identify the "Must" and "Want" criteria that are appropriate for evaluating potential sites for a remote-handled LLW disposal facility. Consideration of regulations, siting guidance, performance requirements, and previous siting studies performed at INL resulted in a total of 53 potential criteria. The 53 criteria were divided into four technical areas and reviewed by subject matter experts to identify criteria most appropriate for this siting evaluation. Appendix B provides a detailed analysis of the screening process and the resulting identification of "Must" and "Want" siting criteria.

\subsubsection{Identify "Must" Site Evaluation Criteria}

"Must" criteria represent site characteristics that are critical, but may be subject to more detailed evaluation, as defined in DOE Orders 435.1 and 420.1B. A total of 17 "Must" criteria were identified from previous studies and three additional potential criteria were identified for consideration in this evaluation. The resulting 20 criteria were reviewed in the described screening process (see Appendix B for analysis and results). Four criteria were identified as appropriate "Must" criteria for this site evaluation process; seven criteria were identified as appropriate for consideration as "Want" criteria; three criteria were substantive duplicates within the 20; and six criteria were eliminated from further consideration. The four "Must" criteria are as follows:

1. Must not be located within 5 miles of a capable fault

2. Must not be located in the 500 -year floodplain 
3. Must not be located in an area of less than 5 acres

4. Must not be located in a wetland.

The "Must" criteria focus on conditions that would clearly prevent locating a remote-handled LLW disposal facility at a given site. Seismic and flooding hazards are clearly identified in DOE orders and standards, and the projected disposal volume dictates a minimum facility area. The fourth criterion, "must not be located in a wetland," rises to the level of a "Must" criterion because there is one jurisdictional wetland at INL, and the nature of the waste (i.e., activated metals and ion-exchange resins) requires that it be disposed of in a dry environment.

\subsubsection{Identify "Want" Site Evaluation Criteria}

"Want" criteria represent important site characteristics that may be evaluated as "poor," "good," or "very good." They may be derived from regulations and DOE orders and often are driven by performance objectives, conceptual design objectives, land use considerations, facility operations, and other unique site factors. The first source of "Want" criteria are those that were evaluated in the "Must" category and determined to be better applied in the "Want" category. Additional "Want" criteria were drawn from previous siting studies (summarized in Appendix A). Using evaluation criteria from previous studies is reasonable because even though several of the previous facilities may be functionally different from a remote-handled LLW disposal facility, many of the desired site-specific features or characteristics are similar. For instance, no matter what the facility type, avoiding volcanic hazard zones is of concern and will be part of the site evaluation. Another benefit of considering criteria from previous studies is that site-specific information or characterization data were previously collected to address those criteria (e.g., seismic ground motion or geotechnical data).

An evaluation of the above sources yielded a total of 42 "Want" criteria. After duplications were eliminated, 36 criteria remained for use in the site evaluation process. In order to focus the presentation in this project siting study report, the full range of potential criteria are defined and screened for applicability in Appendix B. A total of 21 "Want" criteria passed the screening and are presented in Table 3-1 as criteria best suited to identify candidate locations for a remote-handled LLW disposal facility, while the remaining fifteen "Want" criteria were eliminated from further consideration. In order to further focus the criteria evaluation, the selected 21 "Want" criteria have been divided into four groups: (1) geology, (2) hydrology, (3) land use, and (4) natural resources.

In summary, screening of all potential site evaluation criteria resulted in selection of four "Must" and 21 "Want" criteria for use in this onsite disposal facility siting evaluation. The next step in the evaluation process is to identify candidate sites to be screened, scored, and ranked based on the criteria developed specifically for evaluation of this facility.

Table 3-1. Remote-handled low-level waste disposal facility "Want" criteria.

\section{Geology:}

1. Maximize surficial sediment thickness [18]

2. Maximize sediment thickness continuity [19]

3. Enhance retardation to minimize migration [20]

4. Maximize interbed continuity [21]

5. Minimize impact of earthquakes[22]

6. Maximize distance from volcanic hazard zones [23]

7. Locate to facilitate discriminatory monitoring [24] 


\section{Geology: (continued)}

8. Availability of geotechnical data [25]

9. Availability of characterization data [26].

\section{Hydrology:}

10. Minimize proximity to floodplains [29]

11. Avoid aquifer recharge areas [30]

12. Avoid areas of surface water flooding/ponding [31]

13. Avoid perched water [32]

14. Avoid wellhead protection areas [33].

\section{Land Use:}

15. Locate within core infrastructure area [37]

16. Avoid the explosives test area [38]

17. Locate near utilities and transportation [39]

18. Avoid industrial and controlled areas [40].

\section{Natural Resources:}

19. Avoid the Sagebrush-Steppe Ecosystem Reserve [47]

20. Avoid vegetation transects [48]

21. Avoid ecologically sensitive habitat [49].

NOTE: The number in brackets following the criterion is a crosswalk reference to Appendix B where detailed criteria definitions and evaluation are provided.

\subsection{Candidate Site Evaluation}

Candidate sites are identified in this step and a subjective screening is conducted to determine if the candidate sites provide a representative cross-section of locations at INL. Use of previous siting studies facilitated this process by providing a large number of sites that have already been identified for facility siting. This section identifies the candidate sites and summarizes the "Must" and "Want" criteria evaluation results. The criterion-by-criterion evaluation is presented in detail in Appendix $\mathrm{C}$ where figures of each criterion (e.g., 500-year floodplain, areas of ecologically sensitive habitat, and so forth) are presented to support assignment of individual criteria scores for each site.

\subsubsection{Identify Candidate Sites}

A total of 34 sites are identified as candidate locations for a remote-handled LLW disposal facility, as shown in Figure 3-1 and listed in Table 3-1 and Table 3-2. These locations are derived from the previous studies reviewed in Appendix A. Use of these candidate sites is appropriate for several reasons. First, extensive site-specific information and data exist and it is cost and time-effective to take advantage of this information. Secondly, as shown in Figure 3-1, all portions of INL are represented, including the north (Sites 1, 6, 27, and 29), east (Site 26), south (Sites 7, 23, and 31), and west (Site 24). In addition, the central portion of INL (near most of the existing INL facilities) is well represented by the remaining 25 sites. 


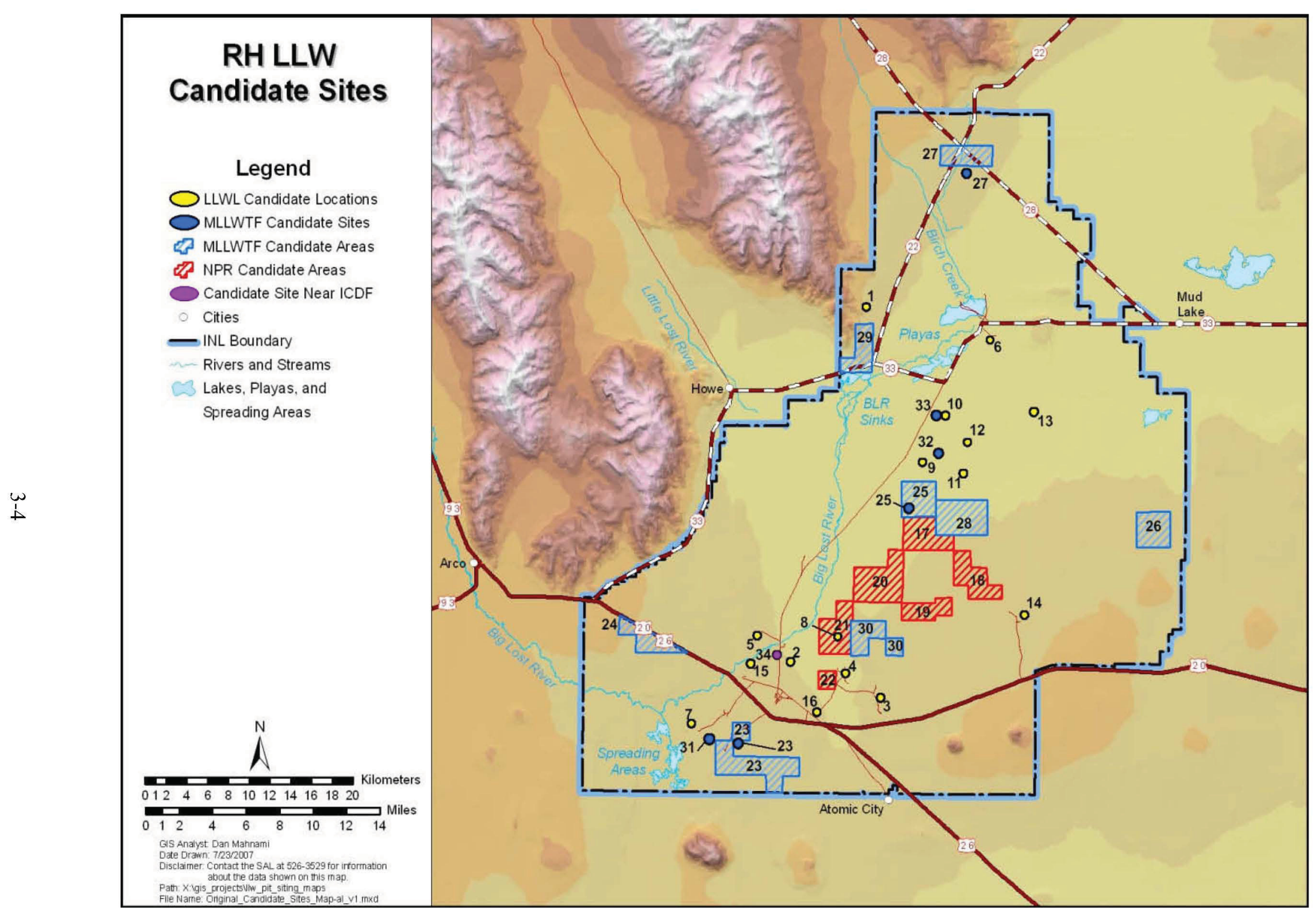

Figure 3-1. Location of the 34 candidate sites within the Idaho National Laboratory boundary. 
Table 3-2. Candidate site locations for an onsite remote-handled low-level waste disposal facility.

\begin{tabular}{|c|c|c|}
\hline $\begin{array}{c}\text { Remote- } \\
\text { Handled LLW } \\
\text { Site Number }\end{array}$ & $\begin{array}{c}\text { Original Past } \\
\text { Siting Study } \\
\text { Identifier } \\
\end{array}$ & Description \\
\hline \multicolumn{3}{|r|}{ LLW Landfill (Holdren et al. 1997) } \\
\hline 1 & 1 & North of Big Lost River Sinks \\
\hline 2 & 2 & South of Idaho Nuclear Technology and Engineering Center (INTEC) \\
\hline 3 & 3 & Near the Auxiliary Reactor Area \\
\hline 4 & 4 & Near the Power Burst Facility \\
\hline 5 & 5 & Near the Advanced Test Reactor (ATR) Complex \\
\hline 6 & 6 & Near Test Area North \\
\hline 7 & 7 & Near RWMC \\
\hline 8 & 8 & Near the New Production Reactor site \\
\hline 9 & 9 & Near United States Geological Survey (USGS) Site 14 \\
\hline 10 & 10 & Near Corehole 2-2A and USGS-18 \\
\hline 11 & 11 & Playa area southeast of USGS Site 14 \\
\hline 12 & 12 & Crater in Section 23 \\
\hline 13 & 13 & Near Second Owsley Canal \\
\hline 14 & 14 & Near Materials and Fuels Complex \\
\hline 15 & 15 & Within Naval Ordnance Disposal Area \\
\hline 16 & 16 & Near the Security Training Facility \\
\hline \multicolumn{3}{|r|}{ New Production Reactor (Spry et al. 1989) } \\
\hline 17 & A & Central portion of INL \\
\hline 18 & $\mathrm{~B}$ & Northwest of the Materials and Fuels Complex \\
\hline 19 & $\mathrm{C}$ & Central portion of INL \\
\hline 20 & $\mathrm{D}$ & Central portion of INL \\
\hline 21 & $\mathrm{E}$ & East-northeast of INTEC \\
\hline 22 & $\mathrm{~F}$ & Near the Power Burst Facility \\
\hline
\end{tabular}

Idaho Waste Processing Facility/MLLW Treatment Facility (Taylor et al. 1994)

\begin{tabular}{lll}
\hline 23 & 1 & East of RWMC \\
24 & 2 & South of Highway 20/26 near western boundary of INL \\
25 & 3 & East-northeast of the Naval Reactors Facility \\
26 & 4 & East-central INL near east boundary \\
27 & 5 & Junction of Highways 28 and 33 in the northern portion of INL \\
28 & 6 & Central portion of INL, about 6 miles east of Lincoln Boulevard \\
29 & 7 & North of Big Lost River Sinks \\
30 & 8 & North of the Auxiliary Reactor Area \\
\hline
\end{tabular}




\begin{tabular}{ccc}
\hline $\begin{array}{c}\text { Remote- } \\
\text { Handled LLW } \\
\text { Site Number }\end{array}$ & $\begin{array}{c}\text { Original Past } \\
\text { Siting Study } \\
\text { Identifier }^{a}\end{array}$ & Description \\
\hline 31 & 9 & Adjacent to RWMC \\
32 & 14 & Near USGS Site 14 \\
33 & 18 & Near Corehole 2-2A and USGS-18 \\
\hline \multicolumn{3}{c}{ ICDF (DOE-ID 1999) } \\
\hline 34 & West of ICDF \\
\hline a. Numbered as they were identified in the previous siting study reports. \\
\hline
\end{tabular}

Previous studies defined both areas and sites differently. An "area" was defined as a contiguous piece of land of 3 to $8 \mathrm{mi}^{2}$ outside of excluded zones (zones excluded after application of their "Must" criteria), and a "site" was defined as a several hundred acre parcel of land within the area. None of the four previous studies provided descriptions that could be used to identify latitude/longitude coordinates for a parcel of land or footprint for the facility being evaluated. Consequently, the locations shown in Figure 3-1 are approximate.

The area required for the remote-handled LLW disposal facility is significantly less than the areas evaluated in the previous studies, approximately 5 acres as opposed to hundreds of acres. The larger "areas" identified in previous studies were considered in this evaluation to provide a comprehensive screening of candidate sites. The larger "areas" were evaluated to determine if the required smaller footprint for the remote-handled LLW disposal facility could be located within the area boundary. Once the most favorable sites were identified through the ranking process (see Sections 3.2.2 and 3.2.3), a site walkover was conducted to evaluate a number of 5 -acre footprints.

\subsubsection{Develop Weighting and Scoring Factors}

Steps 1 and 2 of the site evaluation process have identified four "Must" criteria, 21 "Want" criteria, and a total of 34 candidate sites. The next step of the site evaluation provides an assessment of individual sites against each of the four "Must" and 21 "Want" criteria. Candidate site/criteria assessment is a subjective but logical and informed process that relies on the professional judgment of experts in the field being evaluated.

Table 3-3 was compiled to provide guidance and to illustrate the degree of rigor applied to the evaluation process. As noted in Section 2.2.2, weighting factors were assigned based on the relative importance of one criterion to the others. Weights to each category were assigned with consideration of the following:

- Overall impact to either facility design, construction, operation, or performance

- $\quad$ Technical feasibility of mitigating impacts resulting from each category considered

- $\quad$ Cost associated with mitigating impacts.

As an example, given the importance of the performance assessment process for designing, operating, and closing the facility, the criteria related to radionuclide migration are assigned a weighting factor of five. This score reflects the technical impracticability of mitigating INL's stratigraphic environment while recognizing that geochemical considerations largely determine contaminant transport. Similarly, impacts to sensitive habitat are technically difficult and costly to mitigate, and a weight of four was applied. 
Table 3-3. Assigned weighting factors and rationale.

\begin{tabular}{|c|c|c|}
\hline Criterion & $\begin{array}{l}\text { Weighting } \\
\text { Factor }\end{array}$ & Weighting Factor Rationale \\
\hline \multicolumn{3}{|l|}{ Very High } \\
\hline Maximize Surficial Sediment Thickness & 5 & $\begin{array}{l}\text { Thick surficial sediments provide more design options. Coarser texture sediments facilitate drainage. Mitigation of the absence of } \\
\text { surficial sediment is technically impractical with a very high cost. }\end{array}$ \\
\hline Maximize Sediment Thickness Continuity & 5 & $\begin{array}{l}\text { High uncertainty and variability reduce design options and increase uncertainty in transport predictions. Mitigation of surficial } \\
\text { sediment thickness variability is technically impractical with a very high cost. }\end{array}$ \\
\hline Maximize Retardation to Attenuate Migration & 5 & $\begin{array}{l}\text { Thicker interbed sediments and fine grained materials retard migration, increase radioactive decay time, resulting in reduced } \\
\text { groundwater impacts. Altering in situ interbed thickness is technically impossible. }\end{array}$ \\
\hline Maximize Interbed Continuity & 5 & $\begin{array}{l}\text { Interbed continuity (low uncertainty and variability) lowers transport prediction uncertainty and increases retardation capacity, } \\
\text { lowering risk. Altering in situ interbed thickness variability is technically impossible. }\end{array}$ \\
\hline Minimize Proximity to Floodplains & 5 & $\begin{array}{l}\text { Location within a floodplain is very undesirable. Mitigation within floodplain is technically possible at significant cost. Mitigation } \\
\text { near floodplain possible at lower cost or by increasing distance. }\end{array}$ \\
\hline Avoid the Explosives Test Area & 5 & Location in the Explosive Test Area exclusion zone is unallowable. Ensuring safety of employees/public is of highest importance. \\
\hline \multicolumn{3}{|l|}{ High } \\
\hline Located Within Core Infrastructure Area & 4 & Location within the core infrastructure area is very desirable to be consistent with INL future land-use plans \\
\hline Locate Near Utilities and Transportation & 4 & $\begin{array}{l}\text { Location near existing transportation and utilities is desirable, may significantly reduce offsite impacts associated with providing } \\
\text { new support infrastructure. Development of new support infrastructure is feasible at significant cost. }\end{array}$ \\
\hline Avoid Sagebrush-Steppe Ecosystem Reserve & 4 & $\begin{array}{l}\text { Location within Sagebrush-Steppe Ecosystem Reserve is undesirable because it is one of the last large tracts of this habitat type in } \\
\text { southern Idaho and because of the importance of protecting its biodiversity (e.g., habitat for sage grouse and pygmy rabbits). }\end{array}$ \\
\hline Avoid Ecologically Sensitive Habitat & 4 & Location within ecologically sensitive habitat is undesirable. Mitigation is possible but may have significant cost. \\
\hline \multicolumn{3}{|r|}{ (2) } \\
\hline Minimize Impact from Earthquakes & 3 & $\begin{array}{l}\text { Performance assessment for similar INL facilities suggests that seismic ground motion would have little effect on facility } \\
\text { performance. Technical mitigation possible by increasing distance from sources and through facility design. }\end{array}$ \\
\hline $\begin{array}{l}\text { Maximize Distance from Volcanic Hazard } \\
\text { Zones }\end{array}$ & 3 & $\begin{array}{l}\text { Location near volcanic hazard not desirable because of lava inundation risk and potentially adverse effects on waste from increased } \\
\text { temperature. Technical mitigation possible by increasing distance from sources and through facility design. }\end{array}$ \\
\hline Availability of Characterization Data & 3 & $\begin{array}{l}\text { Characterization data are important to natural phenomena hazard and performance assessment. However, additional } \\
\text { characterization can be obtained at moderate cost. }\end{array}$ \\
\hline Avoid Aquifer Recharge Areas & 3 & $\begin{array}{l}\text { Location away from recharge areas is desirable. Technical mitigation is possible by increasing distance from recharge areas. At the } \\
\text { INL, recharge areas are limited to ephemeral streams and playas. }\end{array}$ \\
\hline Avoid Wellhead Protection Areas & 3 & $\begin{array}{l}\text { Protection of facility water supply is desirable. Technical mitigation is possible through development of external or new potable } \\
\text { water supplies at moderate cost. }\end{array}$ \\
\hline Avoid Vegetation Transects & 3 & Location within vegetation transect is not desirable. Mitigation (site relocation) is possible at moderate cost. \\
\hline \multicolumn{3}{|r|}{ ( } \\
\hline Locate to Facilitate Discriminatory Monitoring & 2 & $\begin{array}{l}\text { Location near known contamination makes discriminatory monitoring more difficult. Mitigation is technically possible through } \\
\text { monitoring network design and sampling strategy at low additional cost. }\end{array}$ \\
\hline Availability of Geotechnical Data & 2 & $\begin{array}{l}\text { Geotechnical data supports design, construction and performance assessment. Geotechnical data can be collected during the } \\
\text { design/construction phases at low cost. }\end{array}$ \\
\hline $\begin{array}{l}\text { Avoid Areas of Surface Water } \\
\text { Flooding/Ponding }\end{array}$ & 2 & $\begin{array}{l}\text { Location in area prone to surface water ponding/flooding is undesirable; however, mitigation is technically possible during design } \\
\text { at low cost (e.g., moving site location to higher ground). Scoring factor addresses degree of adequate drainage. }\end{array}$ \\
\hline Avoid Perched Water & 2 & $\begin{array}{l}\text { Perched water may enhance migration; however, it dilutes concentration and allows early detection. Technical mitigation possible } \\
\text { by avoiding areas of perched water or installation of additional monitoring at low cost. }\end{array}$ \\
\hline \multicolumn{3}{|l|}{ Very Low } \\
\hline Avoid Industrial and Controlled Areas & 1 & Location inside an industrial area is undesirable; however, mitigation within a controlled area is possible at low cost. \\
\hline
\end{tabular}


In contrast, the impact to facility performance, design, operation, and maintenance associated with location in an existing industrial area was determined to be minimal, and a weight of 1 was assigned. The weighting factor distribution across all 21 "Want" criteria is as follows:

$$
\begin{array}{ll}
- & \text { Six "Very High = 5" } \\
\text { - } & \text { Four "High =4" } \\
\text { - } & \text { Six "Medium=3" } \\
\text { - } & \text { Four "Low=2" } \\
\text { - } & \text { One "Very Low = 1." }
\end{array}
$$

The weighting and scoring factors were developed with consideration of guidance or recommendations for longer post-closure timeframes (e.g., 10,000 years). Specifically, an Advisory Committee on Nuclear Waste letter report (Pomeroy et al. 1997) pointed out that no Nuclear Regulatory Commission (NRC) regulatory requirement has been established regarding an LLW performance assessment timeframe. However, the draft NUREG-1573 Performance Assessment Methodology recommended a performance assessment timeframe of 10,000 years, a time sufficiently long to capture the peak dose to the critical population group, and the Performance Assessment Working Group discussion regarding an appropriate timeframe for an LLW performance assessment was presented in the final published version of NUREG-1573 (NRC 2000) as guidance only (as summarized in NUREG-1853, NRC 2007). From a siting study perspective, the most important NRC requirement is that "the disposal site shall be capable of being characterized, modeled, analyzed, and monitored." As a result, this siting study incorporates a concept of "post-closure timeframe" in selection of criteria (including all the natural hazards as criteria) and in assignment of weighting and scoring factors (made with consideration of impacts that could occur over timeframes as long as 10,000 years). This approach incorporates qualitative assessment of longer timeframes in the siting process and still provides adequate screening in support of a performance assessment to be conducted later in the critical design process.

With weighting factors assigned, identification of a uniform process for applying a criterion score is the next step. As noted in Section 2.2.3, "Low," "Medium," and "High" scores of 1, 3, or 5 are defined for each criterion. Table 3-4 indicates the rationale for each level of scoring. Where possible, quantitative measures were chosen to add rigor to the process (e.g., thickness of surficial sediment or interbeds and grain size distribution). In other cases, quantitative measures could not be used; therefore, more qualitative scoring definitions were used (e.g., "moderate" or "good" surface water drainage). The sections that follow apply the evaluation methodology criterion by criterion to each of the candidate sites.

\subsubsection{Screen Against "Must" Criteria}

The third step requires that each of the candidate sites be evaluated against the four "Must" criteria. Previous siting studies all included a "Must" criteria screening process and, consequently, the majority of the sites that were identified for use in this evaluation had already passed some level of "Must" criteria screening. Only three sites failed the siting study "Must" evaluation (as shown in Table 3-5).

Of the three sites that failed, all failed the "Must not be located within 5 miles of a capable fault" criterion. Sites 1 and 29 are both in the area north of the Big Lost River Sinks. The sites are only 3 to 4 miles from the main strand of the Lemhi fault and, consequently, may be subject to relatively high ground motion during an earthquake. The southern end of the Lemhi fault has several strands that approach the two sites and these may lead to surface rupture. Borehole data are limited in this area and this prevents evaluation of ground motion amplification by soils. The USGS seismic response map (USGS 2006) indicates the highest ground motion within INL at this location exceeds $40 \% \mathrm{~g}$ (gravitational acceleration). 
Table 3-4. Criterion scoring definitions, 1 = Low, 3 = Medium, $5=$ High.

\begin{tabular}{|c|c|c|c|}
\hline Criterion & 1 & $\begin{array}{c}\text { Score } \\
3\end{array}$ & 5 \\
\hline \multicolumn{4}{|l|}{ GEOLOGY } \\
\hline Maximize Surficial Sediment Thickness & $\begin{array}{l}\text { Thin fluvial deposits, less than } 10 \mathrm{ft} \text {, or all } \\
\text { lacustrine deposits }\end{array}$ & Thicker fluvial deposits, 10 to $20 \mathrm{ft}$ & Fluvial deposits exceeding $20 \mathrm{ft}$ \\
\hline Maximize Sediment Thickness Continuity & Coefficient of variation greater than 0.60 & Coefficient of variation between 0.30 and 0.60 & Coefficient of variation less than 0.30 \\
\hline Maximize Retardation to Attenuate Migration & $\begin{array}{l}\text { Cumulative fine grain interbed thickness less } \\
\text { than } 10 \mathrm{ft}\end{array}$ & $\begin{array}{l}\text { Cumulative fine grain interbed thickness between } \\
10 \text { and } 20 \mathrm{ft}\end{array}$ & $\begin{array}{l}\text { Cumulative fine grain interbed thickness greater } \\
\text { than } 20 \mathrm{ft}\end{array}$ \\
\hline Maximize Interbed Continuity & Coefficient of variation greater than 0.60 & Coefficient of variation between 0.30 and 0.60 & Coefficient of variation less than 0.30 \\
\hline Minimize Impact from Earthquakes & $\begin{array}{l}\text { Located in areas characterized by very thick } \\
\text { lacustrine sediments }\end{array}$ & $\begin{array}{l}\text { Located in areas characterized by a thicker section } \\
\text { of fluvially deposited sediments over basalt }\end{array}$ & $\begin{array}{l}\text { Located in areas characterized by veneer of } \\
\text { windblown sand over basalt }\end{array}$ \\
\hline $\begin{array}{l}\text { Maximize Distance from Volcanic Hazard } \\
\text { Zones }\end{array}$ & $\begin{array}{l}\text { Within } 5 \text { miles of volcanic vents less than } \\
400,000 \text { years old }\end{array}$ & $\begin{array}{l}\text { From } 5 \text { to } 9 \text { miles of volcanic vents less than } \\
400,000 \text { years old }\end{array}$ & $\begin{array}{l}\text { More than } 9 \text { miles from volcanic vents less than } \\
400,000 \text { years old }\end{array}$ \\
\hline $\begin{array}{l}\text { Locate to Facilitate Discriminatory } \\
\text { Monitoring }\end{array}$ & $\begin{array}{l}\text { Within contaminant plume, poorly developed } \\
\text { monitoring network }\end{array}$ & $\begin{array}{l}\text { Nearby contaminant plume, moderately developed } \\
\text { monitoring network }\end{array}$ & $\begin{array}{l}\text { Outside contaminant plume, well developed } \\
\text { monitoring network }\end{array}$ \\
\hline Availability of Geotechnical Data & $\begin{array}{l}\text { No nearby facilities or investigations provide } \\
\text { existing geotechnical data }\end{array}$ & $\begin{array}{l}\text { Geotechnical data from similar geologic setting } \\
\text { available }\end{array}$ & $\begin{array}{l}\text { Geotechnical data available from facilities or } \\
\text { investigations near the candidate site }\end{array}$ \\
\hline Availability of Characterization Data & $\begin{array}{l}\text { Few to no boreholes in the vicinity to provide } \\
\text { stratigraphic characterization data }\end{array}$ & Some borehole data available near candidate site & $\begin{array}{l}\text { Abundant borehole data available from facilities } \\
\text { near the candidate site }\end{array}$ \\
\hline \multicolumn{4}{|l|}{ HYDROLOGY } \\
\hline Minimize Proximity to Floodplains & Within extent of pluvial Lake Terreton & $\begin{array}{l}\text { Site located on or adjacent to the Big Lost River } \\
\text { floodplain and partially susceptible to inundation } \\
\text { from the } 500 \text {-year or } 1,000 \text {-year floods }\end{array}$ & $\begin{array}{l}\text { Site located on or adjacent to the Big Lost River } \\
\text { floodplain but outside } 1,000 \text {-year floodplain } \\
\text { boundaries. }\end{array}$ \\
\hline Avoid Aquifer Recharge Areas & Within a recharge area & NA & Outside a recharge area \\
\hline $\begin{array}{l}\text { Avoid Areas of Surface Water } \\
\text { Flooding/Ponding }\end{array}$ & $\begin{array}{l}\text { Location where surface water may pond or } \\
\text { flood }\end{array}$ & Moderate surface water drainage & Good surface water drainage \\
\hline Avoid Perched Water & Location is in area with known perched water & $\begin{array}{l}\text { Location is in proximity of known or suspected } \\
\text { perched water }\end{array}$ & $\begin{array}{l}\text { Location is distant from known or suspected } \\
\text { perched water }\end{array}$ \\
\hline Avoid Wellhead Protection Areas & $\begin{array}{l}\text { Location within wellhead protection area, no } \\
\text { mitigation possible }\end{array}$ & $\begin{array}{l}\text { Location within wellhead protection area, } \\
\text { mitigation possible }\end{array}$ & Location outside wellhead protection area \\
\hline \multicolumn{4}{|l|}{ LAND USE } \\
\hline Located Within Core infrastructure Area & Location outside the core infrastructure area & NA & Location inside the core infrastructure area \\
\hline Avoid the Explosives Test Area & Within a designated area & Within a designated buffer around an area & Outside a designated buffer around an area \\
\hline Locate Near Utilities and Transportation & Greater than 1 mile & From 0.5 to 1 mile & Within 0.5 mile \\
\hline Avoid Industrial and Controlled Areas & $\begin{array}{l}\text { Within industrial or controlled area, no } \\
\text { mitigation possible }\end{array}$ & $\begin{array}{l}\text { Within or near industrial or controlled area, } \\
\text { mitigation possible }\end{array}$ & Outside an industrial or controlled area \\
\hline \multicolumn{4}{|l|}{ NATURAL RESOURCE } \\
\hline Avoid Sagebrush-Steppe Ecosystem Reserve & $\begin{array}{l}\text { Location within Sagebrush-Steppe Ecosystem } \\
\text { Reserve }\end{array}$ & NA & $\begin{array}{l}\text { Location outside Sagebrush-Steppe Ecosystem } \\
\text { Reserve }\end{array}$ \\
\hline Avoid Vegetation Transects & $\begin{array}{l}\text { Location within vegetation transect, no } \\
\text { mitigation possible }\end{array}$ & $\begin{array}{l}\text { Location within or near vegetation transect, } \\
\text { mitigation possible }\end{array}$ & Location outside vegetation transect \\
\hline Avoid Ecologically Sensitive Habitat & $\begin{array}{l}\text { Location within } 3 \text { miles of lekking sites, within } \\
1 / 2 \text { mile of raptor nests or pygmy rabbit } \\
\text { burrows, within sensitive plants zone }\end{array}$ & Location 3 to 11 miles from known lekking site & $\begin{array}{l}\text { Greater than } 11 \text { miles from lekking sites, greater } \\
\text { than } 1 / 2 \text { mile from raptor nests or pygmy } \\
\text { burrows, outside sensitive plants zone, or within } \\
\text { burn area }\end{array}$ \\
\hline
\end{tabular}


Table 3-5. "Must" criteria evaluation.

\begin{tabular}{|c|c|c|c|c|c|}
\hline \multicolumn{2}{|c|}{$\begin{array}{c}\text { RH LLW Disposal } \\
\text { Facility Siting } \\
\text { Evaluation }\end{array}$} & 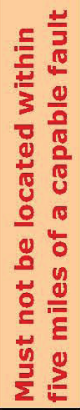 & 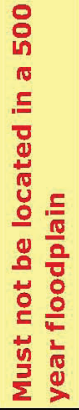 & 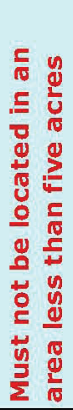 & 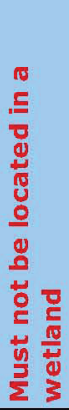 \\
\hline Site & Location & \multirow[b]{2}{*}{$\mathbf{F}$} & \multirow{2}{*}{ 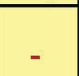 } & \multirow[b]{2}{*}{ - } & \multirow{2}{*}{ - } \\
\hline 1 & North of BLR Sinks & & & & \\
\hline 2 & South of INTEC & $\mathbf{s}$ & $\mathbf{s}$ & $\mathbf{s}$ & $\mathbf{s}$ \\
\hline 3 & Near ARA & 5 & 5 & s & 5 \\
\hline 4 & Near PBF & s & $\mathbf{s}$ & s & 5 \\
\hline 5 & Near RTC (Old TRA) & 5 & 5 & $s$ & 5 \\
\hline 6 & Near TAN (WRRTF) & $s$ & 5 & s & C \\
\hline 7 & Near RWMC & s & $\mathbf{s}$ & s & s \\
\hline 8 & Near NPR & $\mathbf{s}$ & $\mathbf{5}$ & $\mathbf{s}$ & 5 \\
\hline 9 & Near USGS Site 14 & $\mathbf{s}$ & $\mathbf{s}$ & $\mathbf{s}$ & $\mathbf{s}$ \\
\hline 10 & Near USGS Site 18 & s & $\mathbf{s}$ & s & 5 \\
\hline 11 & SE of USGS Site 14 & 5 & 5 & 5 & 5 \\
\hline 12 & Crater in Section 23 & $\mathbf{s}$ & $\mathbf{s}$ & $\mathbf{s}$ & $\mathbf{s}$ \\
\hline 13 & Near 2nd Owsley Canal & $\mathbf{s}$ & $\mathbf{s}$ & $\mathbf{s}$ & $\mathbf{s}$ \\
\hline 14 & Near MFC (Old ANL-W) & $\mathbf{s}$ & $\mathbf{s}$ & $\mathbf{s}$ & $\mathbf{s}$ \\
\hline 15 & Within NODA & $s$ & s & s & $s$ \\
\hline 16 & Near STF & 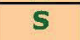 & 5 & s & 5 \\
\hline 17 & NPR Area A & s & $\mathbf{s}$ & $\mathbf{s}$ & $s$ \\
\hline 18 & NPR Area B & $\mathbf{s}$ & $\mathbf{s}$ & $\mathbf{s}$ & $\mathbf{s}$ \\
\hline 19 & NPR Area C & 5 & $\mathbf{s}$ & $\mathbf{s}$ & $\mathbf{s}$ \\
\hline 20 & NPR Area D & $s$ & $\mathbf{s}$ & s & $s$ \\
\hline 21 & NPR Area E & $\bar{s}$ & $\bar{s}$ & $\bar{s}$ & $\bar{s}$ \\
\hline 22 & NPR Area F & $\mathbf{s}$ & $\mathbf{s}$ & $\mathbf{s}$ & 5 \\
\hline 23 & MLLW Area 1 , Site 1 & s & $\mathbf{s}$ & $\mathbf{s}$ & s \\
\hline 24 & MLLW Area 2 & s & $\mathbf{s}$ & $\mathbf{s}$ & $s$ \\
\hline 25 & MLLW Area 3 , Site 3 & s & s & s & s \\
\hline 26 & MLLW Area 4 & 5 & $\mathbf{s}$ & 5 & 5 \\
\hline 27 & MLLW Area 5, Site 5 & $\mathbf{F}$ & - & - & - \\
\hline 28 & MLLW Area 6 & $\mathbf{s}$ & $\mathbf{s}$ & $\mathbf{s}$ & $\mathbf{s}$ \\
\hline 29 & MLLW Area 7 & $\mathbf{F}$ & - & - & - \\
\hline 30 & MLLW Area 8 & 5 & $\mathbf{s}$ & 5 & 5 \\
\hline 31 & MLLW Site 9 & 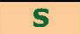 & $\mathbf{s}$ & $\mathbf{s}$ & $s$ \\
\hline 32 & MLLW Site 14 & 5 & $\mathbf{s}$ & $\mathbf{s}$ & 5 \\
\hline 33 & MLLW Site 18 & $\mathbf{s}$ & $\mathbf{s}$ & $\mathbf{s}$ & $\mathbf{s}$ \\
\hline 34 & Near ICDF & s & $\mathbf{s}$ & $\mathbf{s}$ & 5 \\
\hline
\end{tabular}

$\mathrm{C}=$ conditionally satisfies "Must" criterion

$\mathrm{F}=$ failed "Must" criterion

$\mathrm{S}=$ satisfies "Must" criterion
Bedrock is poorly characterized and could range from rhyolite to basalt to limestone. If limestone is present, there is the possibility of solution cavities in the shallow subsurface. The characteristics of this area make it the least desirable location within INL. Site 27 is located at the north end of INL and is also located within 3 miles of a capable fault. The evaluation given above for Sites 1 and 29 is applicable to Site 27 as well.

The remaining 31 candidate sites met all four "Must" criteria. Table 3-5 summarizes the evaluation of each site against the four criteria. The three sites that failed a "Must" criterion are shown with an "F." The sites that satisfactorily met all the "Must" criteria are shown with an "S," and several sites that conditionally met a criterion are shown with a "C." The site receiving a conditional " $\mathrm{C}$ " evaluation is located in a mapped wetland (Site 6). Site 6 was located in an area designated as a "wetland" in the National Wetlands Inventory database and there is some question about the validity of this designation because of its distance from the Birch Creek playas. Should Site 6 be selected through the NEPA process as the preferred site, a natural resource survey would be required to determine if it is truly a wetland. Figure 3-2 presents an INL map of the "Must" criteria in relationship to the 34 candidate sites. This figure was used to complete the evaluation shown in Table 3-5. As a result of screening against "Must" criteria, Sites 1,27 , and 29 were eliminated from further consideration, and the remaining 31 sites were retained for further evaluation.

\subsubsection{Evaluate Against "Want" Criteria}

In Step 4, each of the candidate sites passing the "Must" evaluation are then further evaluated and scored relative to each of the

21 "Want" criteria. Available site characterization data and professional judgment are used to complete the evaluation and assign a score. The "Want" criteria evaluation requires consideration of a broad range of data. Appendix $\mathrm{C}$ presents a series of figures that depict INL-wide data for each of the 21 criteria. The 34 sites are represented on each figure in Appendix $\mathrm{C}$ to illustrate relative ranking criterion-by-criterion, site-by-site. Table 3-6 summarizes the evaluation process documented in Appendix C. The 34 candidate locations are tabulated in the left column and the 21 criteria are identified in the first row. Individual scores for each criterion and site are listed in the column below each criterion. 


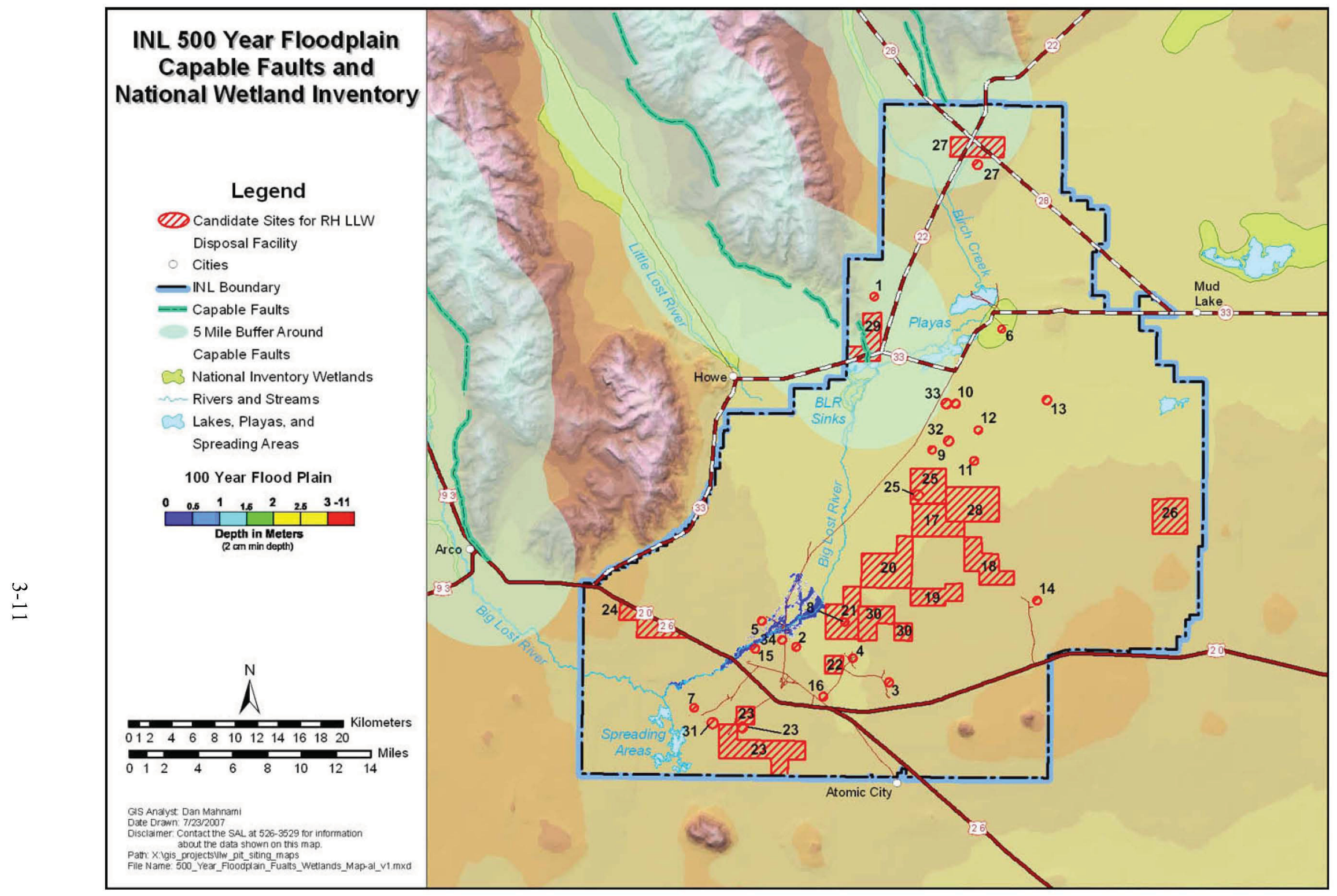

Figure 3-2. Idaho National Laboratory map showing "Must" criteria data. 
Table 3-6. Evaluation of 34 candidate sites against 21 criteria.

\begin{tabular}{|c|c|c|c|c|c|c|c|c|c|c|c|c|c|c|c|c|c|c|c|c|c|c|c|}
\hline \multirow{2}{*}{\multicolumn{2}{|c|}{$\begin{array}{l}\text { Remote Handled LLW } \\
\text { Disposal Facility Site Evaluation }\end{array}$}} & \multicolumn{9}{|c|}{ GEOLOGY } & \multicolumn{5}{|c|}{ HYDROLOGY } & \multicolumn{4}{|c|}{$\begin{array}{l}\text { LAND } \\
\text { USE }\end{array}$} & \multicolumn{3}{|c|}{$\begin{array}{c}\text { NATURAL } \\
\text { RESOURCE }\end{array}$} & \multirow[t]{2}{*}{ TOTAL } \\
\hline & & 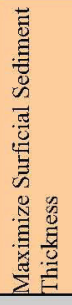 & 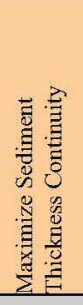 & 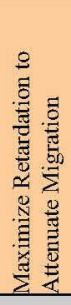 & 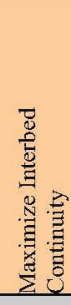 & 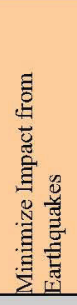 & 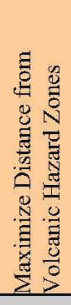 & 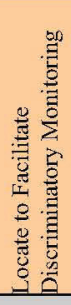 & 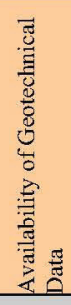 & 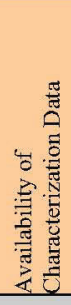 & 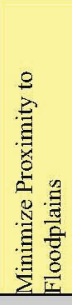 & 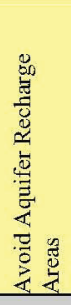 & 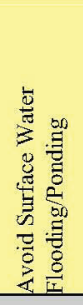 & 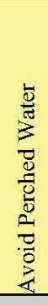 & 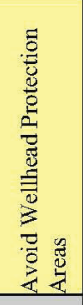 & 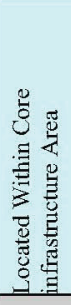 & 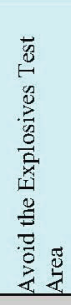 & 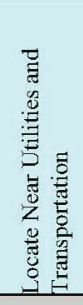 & 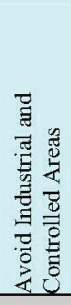 & 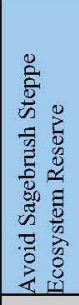 & 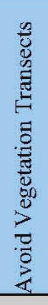 & 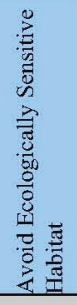 & \\
\hline \multicolumn{2}{|c|}{ WEIGHTING FACTOR $\rightarrow$} & 5 & 5 & 5 & 5 & 3 & 3 & 2 & 2 & 3 & 5 & 3 & 2 & 2 & 3 & 4 & 5 & 4 & 1 & 4 & 3 & 4 & \\
\hline Site & Location & & & & & & & & & & & & & & & & & & & & & & \\
\hline 1 & North of BLR Sinks & & & & & & & & & & & & & & & & & & & & & & 0 \\
\hline 2 & South of INTEC & 1 & 3 & 3 & 5 & 3 & 3 & 3 & 5 & 5 & 5 & 5 & 5 & 3 & 5 & 5 & 5 & 5 & 3 & 5 & 5 & 3 & 291 \\
\hline 3 & Near Auxiliary Reactor Area & 1 & 1 & 1 & 1 & 5 & 1 & 1 & 5 & 5 & 5 & 5 & 5 & 5 & 5 & 5 & 5 & 5 & 3 & 5 & 1 & 3 & 243 \\
\hline 4 & Near Power Burst Facility & 1 & 1 & 1 & 1 & 5 & 1 & 1 & 5 & 5 & 5 & 5 & 5 & 5 & 3 & 5 & 5 & 5 & 1 & 5 & 3 & 1 & 233 \\
\hline 5 & Near ATR & 5 & 5 & 5 & 5 & 3 & 3 & 5 & 5 & 5 & 5 & 5 & 5 & 3 & 3 & 5 & 5 & 5 & 3 & 5 & 5 & 5 & 347 \\
\hline 6 & Near Test Area North & 1 & 5 & 1 & 1 & 1 & 1 & 3 & 5 & 5 & 1 & 5 & 3 & 5 & 5 & 5 & 5 & 5 & 3 & 1 & 5 & 3 & 237 \\
\hline 7 & Near RWMC & 1 & 1 & 1 & 1 & 5 & 1 & 5 & 5 & 5 & 5 & 1 & 1 & 3 & 5 & 5 & 5 & 3 & 3 & 5 & 5 & 1 & 223 \\
\hline 8 & Near New Production Reactor & 1 & 1 & 1 & 1 & 5 & 3 & 5 & 5 & 3 & 5 & 5 & 5 & 5 & 5 & 5 & 5 & 3 & 5 & 5 & 1 & 5 & 253 \\
\hline 9 & Near USGS Site 14 & 1 & 1 & 1 & 1 & 1 & 1 & 5 & 3 & 3 & 1 & 5 & 3 & 5 & 5 & 5 & 3 & 3 & 5 & 5 & 5 & 1 & 209 \\
\hline 10 & Near USGS Site 18 & 1 & 1 & 1 & 1 & 1 & 1 & 5 & 3 & 1 & 1 & 5 & 3 & 5 & 5 & 5 & 3 & 3 & 5 & 1 & 5 & 1 & 185 \\
\hline 11 & SE of USGS Site 14 & 1 & 1 & 1 & 1 & 5 & 1 & 5 & 1 & 1 & 1 & 5 & 1 & 5 & 5 & 5 & 1 & 1 & 5 & 5 & 3 & 1 & 167 \\
\hline 12 & Crater in Section 23 & 1 & 1 & 1 & 1 & 1 & 1 & 5 & 1 & 1 & 1 & 5 & 3 & 5 & 5 & 5 & 3 & 1 & 5 & 1 & 1 & 1 & 159 \\
\hline 13 & $\begin{array}{l}\text { Near 2nd Owsley Canal } \\
\text { Near Materials and Fuels }\end{array}$ & 3 & 1 & 1 & 1 & 1 & 1 & 5 & 1 & 1 & 1 & 5 & 1 & 5 & 5 & 1 & 3 & 1 & 5 & 5 & 5 & 1 & 165 \\
\hline 14 & Complex & 1 & 1 & 1 & 1 & 5 & 1 & 1 & 5 & 3 & 5 & 5 & 5 & 5 & 1 & 5 & 3 & 5 & 3 & 5 & 5 & 1 & 219 \\
\hline 15 & $\begin{array}{l}\text { Within Naval Ordnance Disposal } \\
\text { Area }\end{array}$ & 5 & 3 & 3 & 3 & 3 & 3 & 5 & 5 & 1 & 3 & 5 & 3 & 1 & 3 & 5 & 3 & 3 & 5 & 5 & 5 & 5 & 241 \\
\hline 16 & Near Security Training Facility & 1 & 1 & 1 & 1 & 5 & 1 & 5 & 3 & 5 & 5 & 5 & 3 & 5 & 1 & 5 & 5 & 5 & 5 & 5 & 1 & 1 & 225 \\
\hline 17 & New Production Reactor Area A & 1 & 1 & 1 & 1 & 5 & 3 & 5 & 1 & 1 & 5 & 5 & 5 & 5 & 5 & 5 & 3 & 1 & 5 & 5 & 1 & 3 & 213 \\
\hline 18 & New Production Reactor Area B & 1 & 1 & 1 & 1 & 5 & 1 & 5 & 1 & 1 & 5 & 5 & 5 & 5 & 5 & 5 & 1 & 1 & 5 & 5 & 5 & 1 & 201 \\
\hline 19 & New Production Reactor Area C & 1 & 1 & 1 & 1 & 5 & 3 & 5 & 3 & 1 & 5 & 5 & 5 & 5 & 5 & 5 & 5 & 1 & 5 & 5 & 5 & 1 & 231 \\
\hline 20 & New Production Reactor Area D & 1 & 1 & 1 & 1 & 5 & 3 & 5 & 3 & 1 & 5 & 5 & 5 & 5 & 3 & 5 & 5 & 1 & 5 & 5 & 1 & 1 & 213 \\
\hline 21 & New Production Reactor Area E & 1 & 1 & 1 & 1 & 5 & 3 & 5 & 5 & 3 & 5 & 5 & 5 & 5 & 5 & 5 & 5 & 3 & 5 & 5 & 1 & 3 & 245 \\
\hline 22 & New Production Reactor Area F & 1 & 1 & 1 & 1 & 5 & 3 & 3 & 3 & 3 & 5 & 5 & 5 & 5 & 5 & 5 & 5 & 5 & 3 & 5 & 1 & 3 & 243 \\
\hline 23 & MLLW Area 1, Site 1 & 1 & 1 & 1 & 1 & 5 & 1 & 5 & 3 & 1 & 5 & 5 & 1 & 3 & 5 & 1 & 5 & 3 & 5 & 5 & 3 & 1 & 199 \\
\hline 24 & MLLW Area 2 & 1 & 1 & 1 & 1 & 5 & 1 & 5 & 1 & 1 & 5 & 5 & 5 & 5 & 5 & 1 & 5 & 5 & 5 & 5 & 5 & 5 & 225 \\
\hline 25 & MLLW Area 3, Site 3 & 1 & 1 & 1 & 1 & 5 & 1 & 5 & 1 & 1 & 5 & 5 & 5 & 5 & 5 & 5 & 3 & 1 & 5 & 5 & 1 & 3 & 207 \\
\hline 26 & MLLW Area 4 & 1 & 1 & 1 & 1 & 5 & 1 & 5 & 1 & 1 & 5 & 5 & 5 & 5 & 5 & 1 & 5 & 1 & 5 & 5 & 5 & 1 & 205 \\
\hline 27 & MLLW Area 5, Site 5 & & & & & & & & & & & & & & & & & & & & & & 0 \\
\hline 28 & MLLW Area 6 & 1 & 1 & 1 & 1 & 5 & 1 & 5 & 1 & 1 & 5 & 5 & 5 & 5 & 5 & 5 & 1 & 1 & 5 & 5 & 5 & 3 & 209 \\
\hline 29 & MLLW Area 7 & & & & & & & & & & & & & & & & & & & & & & 0 \\
\hline 30 & MLLW Area 8 & 1 & 1 & 1 & 1 & 5 & 1 & 5 & 3 & 1 & 5 & 5 & 3 & 5 & 5 & 5 & 5 & 1 & 5 & 5 & 1 & 3 & 217 \\
\hline 31 & MLLW Site 9 & 1 & 1 & 1 & 1 & 5 & 1 & 3 & 5 & 5 & 5 & 1 & 3 & 3 & 5 & 5 & 5 & 3 & 3 & 5 & 5 & 1 & 223 \\
\hline 32 & MLLW Site 14 & 1 & 1 & 1 & 1 & 1 & 1 & 5 & 3 & 1 & 1 & 5 & 3 & 5 & 5 & 5 & 3 & 1 & 5 & 5 & 5 & 1 & 185 \\
\hline 33 & MLLW Site 18 & 1 & 1 & 1 & 1 & 1 & 1 & 5 & 3 & 1 & 1 & 5 & 3 & 5 & 5 & 5 & 3 & 5 & 5 & 1 & 5 & 3 & 193 \\
\hline 34 & Near ICDF & 5 & 5 & 5 & 5 & 3 & 3 & 3 & 5 & 5 & 5 & 5 & 5 & 3 & 5 & 5 & 5 & 5 & 3 & 5 & 5 & 5 & 349 \\
\hline
\end{tabular}

Note: Sites that failed the "Must" criteria are shown in bold red; sites recommended for NEPA evaluation are highlighted in green. 
The "total" column at the far right of Table 3-6 is the sum of the criterion score times the weighting factor calculated using the following formula:

Site Score $=\sum_{1}^{21} C_{s} x C W F_{s}$

where

$\mathrm{C}_{\mathrm{S}} \quad=\quad$ individual criterion score

$\mathrm{CWF}_{\mathrm{S}}=$ individual criterion weighting factor.

Applying this formula to each site produces a numerical score that can be used to identify the sites that best satisfy the evaluation criteria. The most satisfactory sites will have the highest score.

\subsection{Remote-Handled Low-Level Waste Disposal Project Site Evaluation Results}

While the site evaluation process used to assess candidate locations for an onsite remote-handled LLW disposal facility produces a discrete numerical score, the process is subjective so a more detailed review of the data will assist with identifying recommended sites. The scores presented in Table 3-6 show that two sites (near ATR and near ICDF) scored 347 and 349 points, respectively. Only two scored between 250 and 300 , and 30 sites received scores lower than 250. Figure 3-3 plots all scores as a histogram showing the number of sites that fall within a designated group. The group width was arbitrarily set at 25 points for ease of illustration. The rank group distribution shows the two sites with scores over 325 clearly separated from the other scoring groups. The three sites that failed the "Must" evaluation are shown in the group labeled " $<150$." The roughly normal distribution of groupings suggests that the selection of a 25-point group width is reasonable.

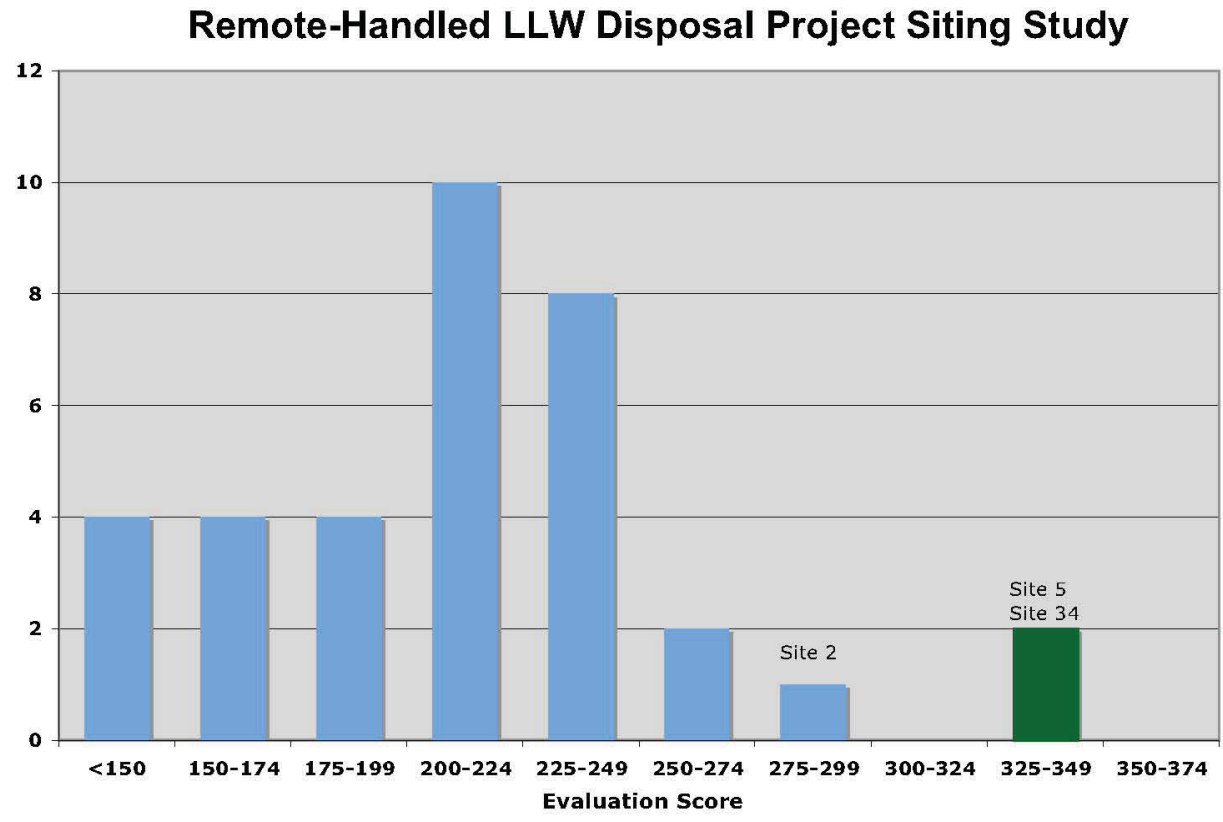

Figure 3-3. Distribution of remote-handled low-level waste candidate site scores. 
The remainder of this section provides a summary of the top two candidate sites. The total possible score in this ranking strategy is 365 . The two top sites each scored above 340 points by receiving a 3 or 5 for each criterion, indicating that they met the highest combination of "Want" criteria and thus represent the recommended alternative locations for consideration in the Remote-Handled LLW Disposal Project NEPA process. Another measure of their suitability is that the two sites were equally strong in each subject area (i.e., geology, hydrology, land use, and natural resources). The following sections highlight the key features of the sites that resulted in their identification as recommended alternative sites for the disposal facility.

\subsubsection{Site 5, Near the Advanced Test Reactor Complex}

Site 5 is located about 0.5 miles southwest of the ATR Complex (Figure 3-4). The figure shows a 45-acre parcel within which the approximately 5 -acre facility would be located. The nine smaller squares each represent 5-acre parcels to indicate options for siting the facility. The site is located in an undisturbed area with existing unpaved road access and is located within 0.25 miles of accessible paved roadway.

A power line is located approximately 1 mile to the east. Surficial sediment thickness, determined from wells in the vicinity of Site 5, ranges from 43 to $73 \mathrm{ft}$ with a mean thickness of $55 \mathrm{ft}$, which is more than adequate to support facility design and construction options. It also has excellent subsurface characteristics to impede downward migration of radionuclides and is located away from potential volcanic hazards.

There are some geotechnical and characterization data from ATR construction activities that may be applicable at this location. Site 5 is outside of aquifer recharge zones and perched water. It is located outside the 1,000-year flood and is not in the ancestral Lake Terreton boundary. However, it is near a perched water zone. For these reasons, the site received a " 5 " and " 3 " rating for Criterion 10 and Criterion 13, respectively, in the "Want" evaluation. The location is within a core infrastructure area but is well away from the explosives test area. The site is not located on the Sagebrush-Steppe Ecosystem Reserve and is not close to vegetation transects.

\subsubsection{Site 34, Southwest of the Idaho CERCLA Disposal Facility}

Site 34 is located west of ICDF and southwest of INTEC. Figure 3-5 shows the 45-acre parcel within which the approximately 5 -acre facility would be located. The nine smaller squares each represent 5 -acre parcels to indicate options for siting the facility.

Power lines are located to the east and west within approximately 0.5 miles of the proposed site. Surficial sediment thickness, determined in wells in the vicinity of Site 34, ranges from 20 to $49 \mathrm{ft}$ with a mean thickness of $31 \mathrm{ft}$. This is sufficient to support design and construction optimization. The site is located away from volcanic hazards.

Abundant geotechnical and characterization data are associated with the nearby facilities (i.e., INTEC). The site is well-drained and not prone to surface water flooding and ponding; it avoids wellhead protection areas and aquifer recharge zones. Within the area investigated, there are 5-acre sites that are above the 1,000-year floodplain so it is recommended that additional flood data be reviewed to firmly establish the final site's relationship to the 1,000-year floodplain. This site scored a " 5 " and " 3 " rating for Criteria 10 and 13, respectively, in the "Want" evaluation. The site is not located in the vicinity of perched water. Site 34 is within a core infrastructure area but well away from the explosives test area. The location has little impact on natural resources, it avoids the Sagebrush-Steppe Ecosystem Reserve and vegetation transects, it is outside identified important habitat, and it is in a previously disturbed area so that its selection would not have an adverse effect on the overall biodiversity across INL. 


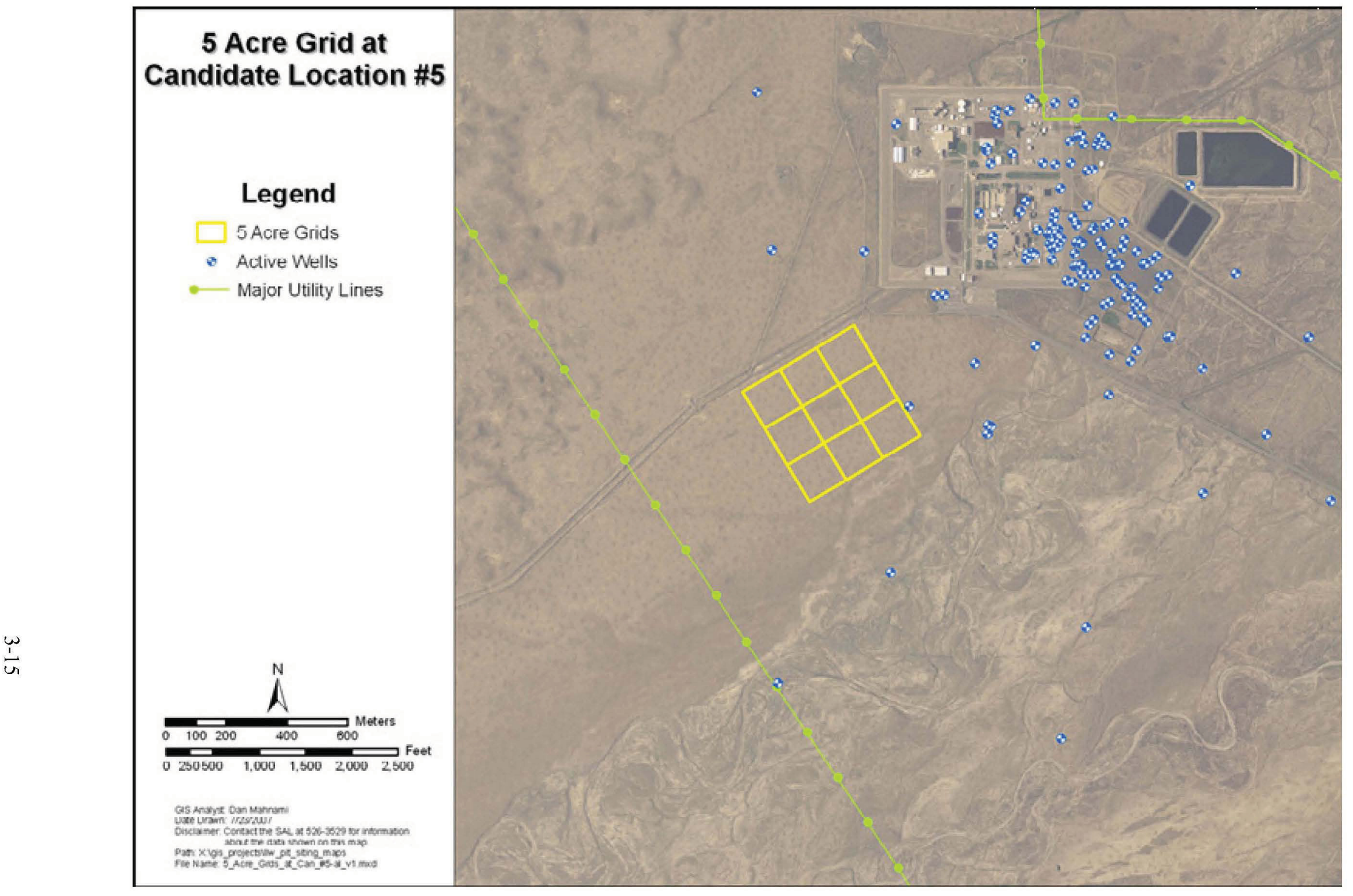

Figure 3-4. Candidate Site 5, near the Advanced Test Reactor Complex. 


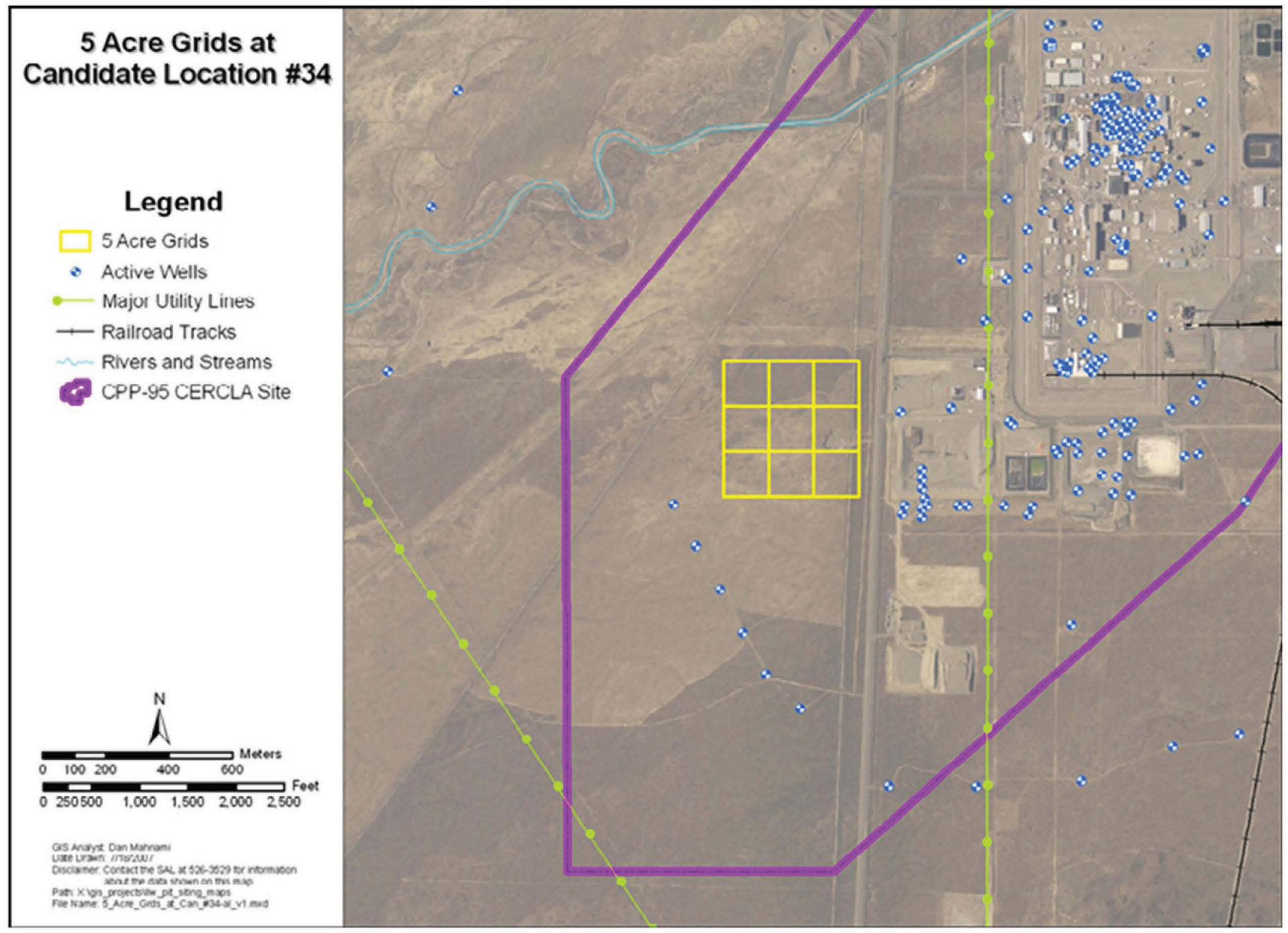

Figure 3-5. Candidate Site 34, near the Idaho CERCLA Disposal Facility. 


\section{REFERENCES}

10 CFR 61, 2002, Title 10, "Energy," Part 61, "Licensing Requirements for Land Disposal of Radioactive Waste," Code of Federal Regulations, Office of the Federal Register.

DOE Order 413.3B, "Program and Project Management for Acquisition of Capital Assets," U.S. Department of Energy, July 28, 2006.

DOE Order 420.1B, "Facility Safety," U.S. Department of Energy, December 22, 2005.

DOE Order 435.1, "Radioactive Waste Management," U.S. Department of Energy, August 28, 2001.

DOE-STD-1189-2008, "Integration of Safety into the Design Process," U.S. Department of Energy, March 2008.

DOE-ID, 1999, Final Record of Decision Idaho Nuclear Technology and Engineering Center, Operable Unit 3-13, DOE/ID-10660, Revision 0, U.S. Department of Energy Idaho Operations Office, Idaho Falls, Idaho.

Holdren, K. J., J. D. Burgess, K. N. Keck, D. L. Lowrey, M. J. Rohe, R. P. Smith, C. S. Staley, and J. Banaee, 1997, Preliminary Evaluation of Potential Locations on the Idaho National Engineering and Environmental Laboratory for a High-Level Waste Treatment and Interim Storage Facility and a Low-Level Waste Landfill, INEEL/EXT-97-01324, Revision 0, Lockheed Martin, Idaho Falls, Idaho.

INL, 2009, Low-Level Waste Disposal Alternatives Analysis Report, INL/EXT-09-17152, Idaho National Laboratory, Idaho Falls, Idaho, October 2009.

NRC, 2000, A Performance Assessment Methodology for Low-Level Radioactive Waste Disposal Facilities, Recommendations of NRC's Performance Assessment Working Group, NUREG 1573, Performance Assessment Working Group, Division of Waste Management, Office of Nuclear Material Safety and Safeguards, U.S. Nuclear Regulatory Commission, October 2000.

NRC, 2007, History and Framework of Commercial Low-Level Radioactive Waste Management in the United States, NUREG 1853, Advisory Committee on Nuclear Waste White Paper prepared by M. T. Ryan, M. P. Lee, and H. J. Larson, Advisory Committee on Nuclear Waste, U.S. Nuclear Regulatory Commission, Washington, DC 20555-0001.

Pomeroy, P. W., B. J. Garrick, W. J. Hinze, G. M. Hornberger, and J. T. Larkins, "Time of Compliance for Low-Level Nuclear Waste Disposal Facilities," February 11, 1997, in: A Compilation of Reports of The Advisory Committee on Nuclear Waste, July 1996 - June 1997, U.S. Nuclear Regulatory Commission, August 1997.

Spry, M. J., K. S. Moor, S. J. Maheras, and H. K. Peterson, 1989, Site Selection Report for the New Production Reactor at the Idaho National Engineering Laboratory, EGG-NPR-8517, Revision 1, EG\&G Idaho, Inc., Idaho Falls, Idaho.

Taylor, D. D., R. L. Hoskinson, C. O. Kingsford, and L. W. Ball, 1994, Preliminary Siting Activities for New Waste Handling Facilities at the Idaho National Engineering Laboratory, EGG-WM-11118, EG\&G Idaho, Inc., Idaho Falls, Idaho.

USGS, 2006, Quaternary Fault and Fold Database for the United States, Accessed July 6, 2007, from U.S. Geological Survey web site: http//earthquakes.usgs.gov/regional/qfaults/. 
Appendix A

\section{Site Evaluation Requirements}




$$
\text { A-2 }
$$




\section{CONTENTS}

ACRONYMS

A-1. DEPARTMENT OF ENERGY REQUIREMENTS

A-1.1 DOE Order 420.1B, Facility Safety A-10

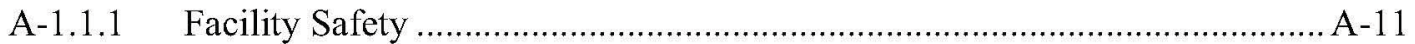

A-1.1.2 Environmental Conditions.................................................................. A-12

A-1.2 DOE Order 435.1, Radioactive Waste Management ...................................................A-12

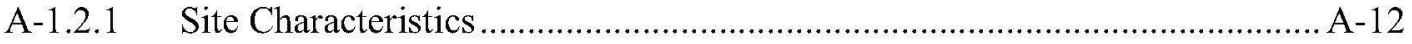

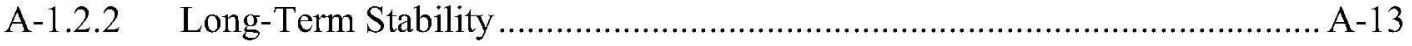

A-1.3 DOE Order 430.1B, Real Property Asset Management …........................................ A-13

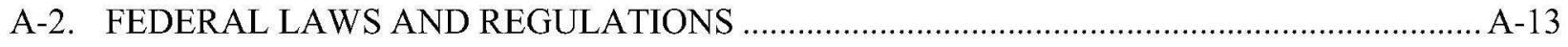

A-2.1 10 CFR 61 Subpart C, Performance Objectives ....................................................... A-14

A-2.1.1 Protection of the General Population from Releases of Radioactivity (10 CFR

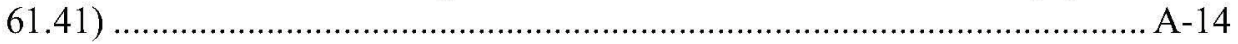

A-2.1.2 Protection of Individuals from Inadvertent Intrusion (10 CFR 61.42)..........A-14

A-2.1.3 Protection of Individuals During Operations (10 CFR 61.43) ..................... A-14

A-2.1.4 Stability of the Disposal Site after Closure (10 CFR 61.44) .......................... A-14

A-2.2 10 CFR 61.50, Disposal Site Suitability Requirements for Land Disposal ...................A-15

A-2.2.1 Characterization (10 CFR 61.50(2)) ….................................................

A-2.2.2 Demographics Requirement (10 CFR 61.50(3)) …................................ A-15

A-2.2.3 Exploitable Natural Resources (10 CFR 61.50(4)) …............................... A-15

A-2.2.4 Surface Water Flooding or Ponding (10 CFR 61.50(5)) ………................. A-15

A-2.2.5 Surface Water Runoff (10 CFR 61.50(6)) .................................................. A-16

A-2.2.6 Depth to Water Table (10 CFR 61.50(7)) …................................................ A-16

A-2.2.7 Groundwater Discharge to Surface (10 CFR 61.50(8)) .................................16

A-2.2.8 Avoid Tectonically Active Areas (10 CFR 61.50(9)) ................................ A-16

A-2.2.9 Avoid Areas Subject to Erosion, Landslides, or Mass Wasting (10 CFR

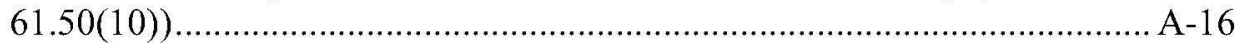

A-2.2.10 Facility Interaction (10 CFR 61.50(11)) ..............................................

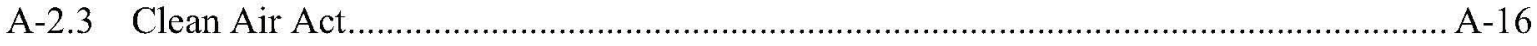

A-2.3.1 National Emission Standards for Hazardous Air Pollutants ........................A-16

A-2.3.2 Clean Air Act Class I Areas .................................................................. A-17

A-2.4 Hazardous Waste Management Act/Resource Conservation and Recovery Act and Related Requirements 


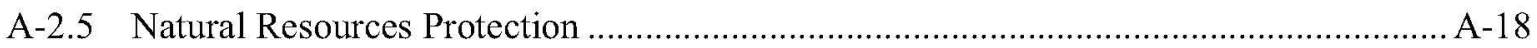

A-2.5.1 Endangered Species Act ..................................................................... A-18

A-2.5.2 Wetlands and Floodplains .....................................................................

A-2.6 Historical, Tribal, and Cultural Resources Protection .............................................. A-19

A-2.6.1 National Historic Preservation Act .......................................................... A-20

A-2.6.2 Archaeological and Historic Preservation Act ........................................ A-21

A-2.6.3 Archaeological Resources Protection Act ............................................. A-21

A-2.6.4 American Antiquities Act................................................................. A-21

A-2.6.5 American Indian Religious Freedom Act...............................................A-21

A-2.6.6 Native American Graves Protection and Repatriation Act ......................... A-22

A-2.6.7 Executive Order 13175, Consultation and Coordination with Indian Tribal Governments ............................................................................. A-22

A-2.7 State and Local Requirements .......................................................................... A-22

A-3. FACILITY SPECIFIC REQUIREMENTS AND OBJECTIVES …........................................... A-22

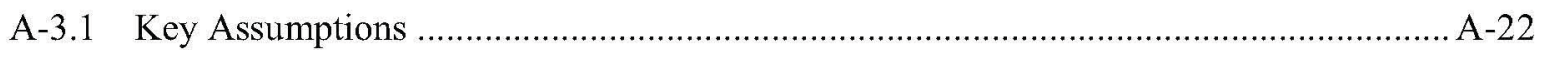

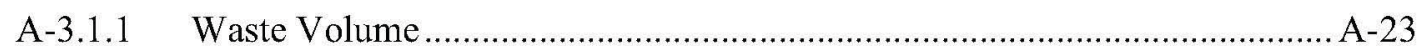

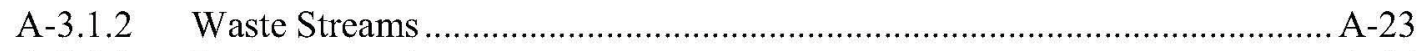

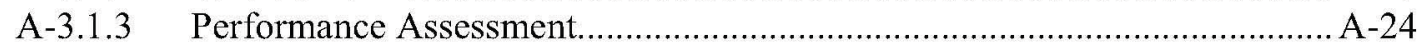

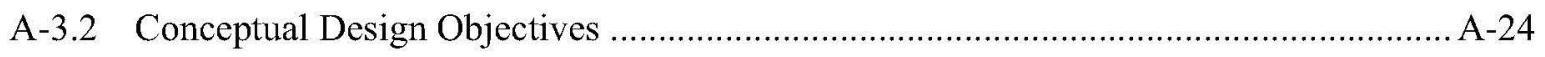

A-3.2.1 Disposal Facility Size Requirements...................................................... A-25

A-3.2.2 Support Infrastructure Requirements .................................................... A-26

A-3.2.3 Design/Construction Requirements.......................................................

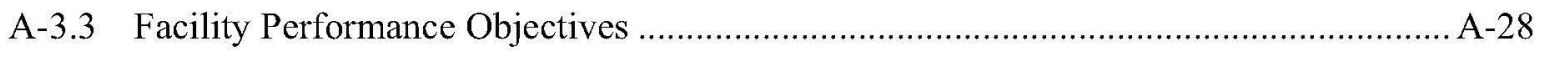

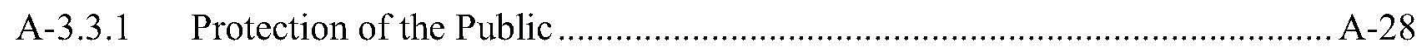

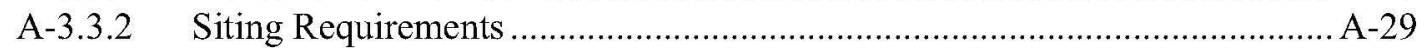

A-3.3.3 Radionuclide Performance Assessment ..................................................... A-29

A-3.3.4 Natural Phenomena Hazards Assessment ................................................. A-30

A-4. PREVIOUS INL SITING STUDIES …........................................................................... A-33

A-4.1 Low-Level Waste Landfill .................................................................................... A-33

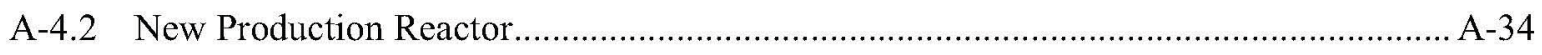

A-4.3 Idaho Mixed and Low-Level Waste Disposal Facility ............................................ A-35

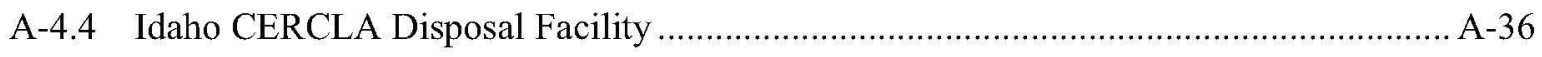

A-4.5 Compilation of Previous Siting Study Criteria....................................................... A

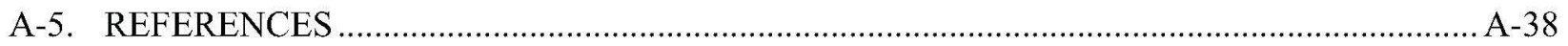




\section{FIGURES}

A-1. Radioactive Waste Management Complex conceptual vault design. ........................................ A-25

\section{TABLES}

A-1. Site-specific data needed to support radionuclide performance assessment.

A-2. Comparison of facility category and associated design basis earthquake, as described in DOE-STD-1020, DOE-STD-1021, and ANSI/ANS-2.26, ASCE/SEI 43-05.

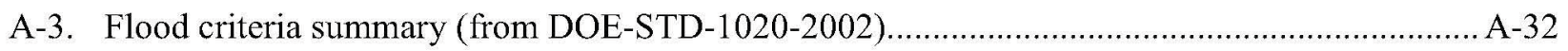




\section{ACRONYMS}

AHPA Archaeological and Historic Preservation Act

ATR Advanced Test Reactor

BOR Bureau of Reclamation

CERCLA Comprehensive Environmental Response, Compensation, and Liability Act

CFR Code of Federal Regulations

CRM Cultural Resource Management

DBE Design Basis Earthquake

DBFL design basis flood

DOE U.S. Department of Energy

EPA Environmental Protection Agency

ESA Endangered Species Act

IBC International Building Code

ICDF Idaho CERCLA Disposal Facility

INL Idaho National Laboratory

INTEC Idaho Nuclear Technology and Engineering Center

IWPF Idaho Waste Processing Facility

LLW low-level waste

MCE maximum considered earthquake

MFC Materials and Fuels Complex

MLLW mixed and low-level waste

NEPA National Environmental Policy Act

NESHAP National Emission Standards for Hazardous Air Pollutants

NHPA National Historic Preservation Act

NOAA National Oceanic and Atmospheric Administration

NPH natural phenomenon hazard 


$\begin{array}{ll}\text { NPR } & \text { New Production Reactor } \\ \text { NRC } & \text { Nuclear Regulatory Commission } \\ \text { NRF } & \text { Naval Reactors Facility } \\ \text { NRHP } & \text { National Register of Historic Places } \\ \text { PC } & \text { performance category } \\ \text { ROD } & \text { Record of Decision } \\ \text { RTC } & \text { Reactor Technology Complex } \\ \text { RWDP } & \text { Remote-Handled Waste Disposition Project } \\ \text { RWMC } & \text { Radioactive Waste Management Complex } \\ \text { SSC } & \text { structure, system, and component } \\ \text { T\&FR } & \text { technical and functional requirement } \\ \text { UBC } & \text { Uniform Building Code } \\ \text { USFWS } & \text { U.S. Fish and Wildlife Service } \\ \text { WAC } & \text { waste acceptance criteria } \\ \text { WAG } & \text { waste area group } \\ \text { WF } & \text { weighting factor }\end{array}$




\section{Appendix A \\ Site Evaluation Requirements}

The siting evaluation process must consider a variety of criteria that address requirements derived from (1) Department of Energy (DOE) Orders, Manuals, Guides, or Standards; (2) federal laws and regulations; and (3) facility specific design and performance objectives. This appendix provides a review of these areas to identify requirements applicable to siting a DOE remote-handled low-level waste (LLW) disposal facility. The requirements are summarized from DOE Orders, Manuals, and Guidance, as well as from statutes and regulations that govern activities involved in siting, constructing, and operating a LLW Disposal Facility.

To further complete the compilation of requirements, consideration is given to key assumptions necessary at the conceptual design phase and to the performance objectives of the facility. Finally, previous siting studies are reviewed to determine the nature of the facilities for which each study was performed and to analyze the siting criteria that were used in these studies. Four such past facility siting evaluations, performed for potential facilities on INL, are available for this review. This review is focused on identifying the requirements in each study applicable to siting a remote-handled LLW disposal facility for waste streams limited to activated metals and ion-exchange resins. Identification of the requirements leads to selection of criteria to support this siting evaluation. The remainder of this appendix provides a summary of:

- $\quad$ DOE Orders, Manuals, Guides, or Standards (Section A-1)

- $\quad$ Federal Laws and Regulations (Section A-2)

- $\quad$ Facility Specific Design and Performance Objectives (Section A-3)

- $\quad$ Key Assumptions

- Conceptual Design Objectives

- $\quad$ Facility Performance Objectives

- $\quad$ Previous Idaho National Laboratory (INL) Siting Studies (Section A-4).

Only site evaluation requirements are identified in this Appendix. The summary discussions of the previous siting studies in Section A-4 also identify the "Must" criteria used in their particular evaluation (see Section 2.1 of this Siting Evaluation Report for definition of "Must" and "Want" criteria) simply to demonstrate the variability in the process of transforming requirements into criteria. Appendix B presents a compilation of both the "Must" and the "Want" criteria from the previous studies, as well as additional evaluation criteria developed from the requirements described in the following sections.

\section{A-1. DEPARTMENT OF ENERGY REQUIREMENTS}

The DOE Orders that identify requirements for evaluating candidate sites are DOE Order 420.1B, Facility Safety, DOE Order 435.1, Radioactive Waste Management and DOE Order 430.1B, Real Property Asset Management. These Orders provide guidance on facility siting considerations and each is supported by manuals, guidance documents and/or standards that provide additional detail that is used to identify criteria for the wide variety of facilities located within the DOE complex. The pertinent material in each of these Orders is summarized below. 


\section{A-1.1 DOE Order 420.1B, Facility Safety}

The purpose of DOE Order 420.1B is to set programmatic requirements for DOE facility safety, including safety design criteria. For new facilities, location can be an important aspect of assuring facility safety. The Order and associated Guidance address siting considerations and mitigation of natural phenomena hazards (NPHs).

DOE Guide 420.1-1, Nonreactor Nuclear Safety Design Criteria and Explosives Safety Criteria Guide for use with DOE Order 420.1, Facility Safety identifies siting as an element of defense-in-depth objectives related to safety design and construction. According to DOE Guide 420.1-1, "Consider site locations that reduce the need to provide design measures to alleviate potentially hazardous conditions or to protect surrounding populations."

DOE Guide 420.1-2, Guide for the Mitigation of Natural Phenomena Hazards for DOE Nuclear Facilities and Nonnuclear Facilities provides additional guidance on the siting criteria to be considered to avoid the consequences of NPHs. An important concept embodied in DOE Guide 420.1-2 is the application of a graded approach in evaluation of a site and application of specific criteria. The criteria identified in the two referenced DOE Guides can be grouped into two common areas: (1) facility safety, and (2) environmental conditions. Elements in each of these areas are identified in the following standards and guides.

DOE Guide 421.1-2, Implementation Guide for Use in Developing Documented Safety Analyses to Meet Subpart B of 10 Code of Federal Regulations (CFR) 830 describes the requirements of Title 10 CFR Part 830, Subpart B, "Safety Basis Requirements," for analysis of DOE nuclear facilities to document the work to be performed, the associated hazards, and to identify the conditions, safe boundaries, and hazard controls necessary to protect workers, the public, and the environment from adverse consequences. These analyses and hazard controls constitute the safety basis that demonstrates the facility can be operated safely. Performing work consistent with the safety basis provides reasonable assurance of adequate protection of workers, the public, and the environment. This Guide elaborates on the documented safety analysis (DSA) development process and the safe harbor provisions of the Appendix to 10 CFR 830 Subpart B.

DOE-STD-1189-2008, Integration of Safety into the Design Process identifies DOE expectations for incorporating safety into the design process for new or major modifications to DOE Hazard Category 1,2 , and 3 nuclear facilities. The intended purpose of the standard is to promote the identification and incorporation of safety components needed within a facility early in the design phase and to help ensure that the facility provides safe handling of hazardous materials, both radiological and chemical, in a way that provides adequate protection for the public, workers, and the environment. The Standard describes the Safety-in-Design philosophies to be used with the project management requirements of DOE Order (O) 413.3B, Change (Chg) 1, Program and Project Management for the Acquisition of Capital Assets, and incorporates the facility safety criteria in DOE Order 420.1B, Facility Safety, as a key foundation for Safety-in-Design determinations.

DOE-STD-1020-2002, Natural Phenomena Hazards Design and Evaluation Criteria for Department of Energy Facilities provides information to help meet the requirements of 10 CFR Part 830, "Nuclear Safety Management for Nuclear Facilities," and DOE Order 420.1B and its associated Guides and Standards, accounting for cancellation of DOE Order 6430.1A. There is an established hierarchy in the set of documents that specify NPH requirements. In this hierarchy, 10 CFR Part 830 (for Nuclear Facilities only) has the highest authority followed by DOE Order 420.1B and the associated Guides DOE Guide 420.1-1 and DOE Guide 420.1-2, which are then followed by the four NPH standards, DOESTDS-1020, 1021, 1022, and 1023. In the event of conflicts in the information provided, the document of 
higher authority should be utilized (e.g., the definitions provided in the Guides should be utilized even though corresponding definitions are provided in the NPH standards). DOE-STD-1189-2008 provides additional guidance on integrating safety elements into the design process that is completed in accordance with DOE Order 420.1B and DOE Order 413.3B.

DOE-STD-1021-2002, Natural Phenomena Hazards Performance Categorization Guidelines for Structures, Systems, and Components provides guidelines to be used for NPH performance categorization of structures, systems, and components (SSCs), and recommends systematic procedures to implement these guidelines. It applies to all Department of Energy (DOE) facilities that are covered by DOE Order 420.1B. 10 CFR Part 830 requires the use of a "graded approach" in performing safety analysis and evaluation of DOE facilities for normal operating and accident conditions, including accidents caused by NPH events. The NPH Guide to DOE Order 420.1B (DOE Guide 420.1-2) uses this "graded approach" and requires, for the purpose of NPH design and evaluation, placing the SSCs comprising the DOE facilities into five NPH performance categories. NPH performance categorization guidelines provided in this technical standard are based on the system safety classification and hazard categorization/classification data obtained from the application of 10 CFR Part 830, DOE-STD-3009-94 (CHG-1), and DOE-STD-1027-92.

DOE-STD-3009-94, Change Notice (CN) 3, Preparation Guide for U.S. Department of Energy Nonreactor Nuclear Facility Safety Analysis describes a documented safety analysis preparation method that is delineated for specific facilities listed in 10 CFR 830. It was developed to assist in preparing SARs for Hazard Category 2 and 3 facilities that will satisfy the requirements of 10 CFR 830. Hazard Category 1 facilities are typically expected to be Category A reactors for which extensive precedents for SARs already exist. Guidance provided by this Standard is generally applicable to any facility required to document its safety basis in accordance with 10 CFR 830 . The methodology provided by this Standard focuses more on characterizing facility safety (i.e., back-end approach) with or without well-documented information than on the determination of facility design (i.e., front end approach). Accordingly, conceptual designs for new facilities and the development of associated preliminary documented safety analyses (PDSAs) should use the process and format of this Standard to the extent it is judged to be of benefit.

\section{A-1.1.1 Facility Safety}

General criteria related to facility safety focus on needed utilities and emergency response, while other criteria are addressed through the National Environmental Policy Act (NEPA) analysis and focus on potential hazards to workers, the public, or other nearby facilities. The following criteria may be considered in the siting evaluation process, following a graded approach based on the nature of the facility:

- $\quad$ Facility safety:

- $\quad$ Utility systems essential to support safety class structures, systems, and components

- $\quad$ Emergency response considerations and proximity of services such as the fire department and emergency medical centers.

- NEPA analysis:

- $\quad$ The site boundary and land-use characteristics of the site surroundings, including properties at risk from accidental exposures, public exclusion zones (access control), population-center distances, and population density 
- $\quad$ Potential human-induced hazards from nearby facilities or activities

- Proximity and hazard to other facilities from the proposed facility.

\section{A-1.1.2 Environmental Conditions}

DOE Guide 420.1-2 focuses on site-specific geology and geotechnical characteristics, hydrology, and NPHs. The following criteria may be considered in the siting evaluation process, following a graded approach based on the nature of the facility:

- Geological and subsurface elements such as earthquake loading, soil bearing design capacity, rock or other bearing stratum, and groundwater elevations

- $\quad$ NPHs based upon site-specific considerations

- Floodplains or areas that are potentially subject to flooding due to dam failures

- $\quad$ Seismicity and geological hazards

- Soil failure hazards.

\section{A-1.2 DOE Order 435.1, Radioactive Waste Management}

DOE Order 435.1, Radioactive Waste Management, and its associated Manuals and Guides govern management of radioactive waste at DOE facilities, including but not limited to siting requirements for locating a LLW disposal facility. Chapter I of DOE Manual 435.1-1, Radioactive Waste Management Manual requires that new waste management facilities be sited and designed in accordance with DOE Order 420.1, Facility Safety, and DOE Order 430.1A, Life-Cycle Asset Management [Cancelled 09/24/2003 by DOE Order 430.1B, Real Property Asset Management] (DOE Manual 435.1-1, I.1.E(18)) and specifies responsibilities of the DOE Field Element Manager (DOE Manual 435.1-1, I.2.F) related to radioactive waste management. Chapter IV of DOE Manual 435.1-1 provides specific requirements for the siting, design, operation, monitoring, and closure of new radioactive waste disposal facilities. The siting requirements (DOE Manual 435.1-1, IV.M.1) may be developed into specific siting criteria.

\section{A-1.2.1 Site Characteristics}

The guidance provided in DOE Manual 435.1 IV M(1)(a) states that a siting evaluation will consider four broad areas. It is important to note the guidance clearly focuses on whether a site can be characterized and that engineered protection through facility design may be used to augment site characteristics, when necessary. The four areas to be considered in the site evaluation are:

1. Environmental characteristics

2. Geotechnical characteristics

3. Human activities

4. Location characteristics:

- Can accommodate the projected volume of waste

- $\quad$ Is in a floodplain 
- Is in a tectonically active area

- $\quad$ Is in a zone of water table fluctuation

- $\quad$ Is in an area where migration pathways are predictable

- $\quad$ Is in an area where erosion and surface water runoff can be controlled.

The purpose of the siting evaluation is to document site characteristics in such a way that facility design can incorporate adequate protection in each of the areas noted above, if needed. A site is deemed unsuitable if adequate protection in each of these areas cannot be provided through facility design. A site requiring fewer facility design modifications will be deemed more suitable (e.g., a site requiring engineered migration barriers will rank lower than a site with natural migration barriers).

\section{A-1.2.2 Long-Term Stability}

The final overarching requirement is that a remote-handled LLW disposal facility shall be sited to achieve long-term stability and to minimize, to the extent practical, the need for active maintenance following final closure (DOE Manual 435.1 IV M(1)(c)). Appendix B provides a complete compilation of siting criteria derived from DOE Order 435.1 and other sources, and it documents a screening process to focus siting criteria on the requirements for this particular LLW Disposal Facility. DOE Manual 435.1 IV $\mathrm{P}(2)$ identifies a 1,000 year post-closure period for facility performance assessment.

\section{A-1.3 DOE Order 430.1B, Real Property Asset Management}

DOE Order 430.1B, which complements DOE Order 413.3B, Program and Project Management for the Acquisition of Capital Assets, puts the Department on the path to improve the management of its real property facilities and infrastructure. The directive establishes an integrated corporate-level, performance based approach to the life-cycle management of the Department's real property assets. It links real property asset planning, programming, budgeting and evaluation to the Department's multi-faceted missions.

Compliance with this Order will assist in assuring that a remote-handled LLW disposal facility is properly sized and planned to meet INL's disposal needs for activated metals and resins. Through application of this Order, planned land use is a key criteria for consideration in facility siting. The disposal facility planning will be integrated with plans for other facilities such as the Ten Year Site Plan to assure that it is located and operated to meet the disposal needs of on-site INL waste generators.

\section{A-2. FEDERAL LAWS AND REGULATIONS}

Federal laws and regulations cover a wide spectrum of requirements that should be considered when performing a siting evaluation. 10 CFR 61, "Licensing Requirements for Land Disposal of Radioactive Waste" addresses performance assessment standards and siting regulations. While these Nuclear Regulatory Commission (NRC) requirements are not applicable to DOE, they are quite useful in determining criteria that support site evaluation. There are additional federal laws that mandate consideration of air pollution, protection of natural resources, and protection of archaeological, historical, and cultural resources. Each of these areas is reviewed below. 


\section{A-2.1 10 CFR 61 Subpart C, Performance Objectives}

The NRC regulations for LLW disposal found at 10 CFR 61 Subpart C, "Performance Objectives (Parts 40 through 44)," address performance requirements that apply to facilities to be licensed by NRC. Similar performance objectives are defined in DOE Order 435.1 to which LLW disposal facilities must be sited, designed, operated, maintained, and closed so that a reasonable expectation exists that the performance objectives will be met. Compliance is demonstrated through the performance assessment and composite analysis required by DOE Order 435.1 . While the NRC regulations are not directly applicable to DOE facilities, they provide additional insight into developing siting criteria related to short term and long term integrity of the facility. The general requirement is that "Land disposal facilities must be sited, designed, operated, closed, and controlled after closure so that reasonable assurance exists that exposures to humans are within the limits established in the performance objectives in $\$ \S 61.41$ through 61.44." Review of the four specific objectives may lead to the use of siting criteria that enhance performance of the remote-handled LLW disposal facility. The following sections present the four performance objectives of 10 CFR 61.4-44.

\section{A-2.1.1 Protection of the General Population from Releases of Radioactivity (10 CFR 61.41)}

Concentrations of radioactive material which may be released to the general environment in ground water, surface water, air, soil, plants, or animals must not result in an annual dose exceeding an equivalent of 25 millirems (mrems) to the whole body, 75 mrems to the thyroid, and 25 mrems to any other organ of any member of the public. Reasonable effort should be made to maintain releases of radioactivity in effluents to the general environment as low as is reasonably achievable.

\section{A-2.1.2 Protection of Individuals from Inadvertent Intrusion (10 CFR 61.42)}

Design, operation, and closure of the land disposal facility must ensure protection of any individual inadvertently intruding into the disposal site and occupying the site or contacting the waste at any time after active institutional controls over the disposal site are removed.

\section{A-2.1.3 Protection of Individuals During Operations (10 CFR 61.43)}

Operations at the land disposal facility must be conducted in compliance with the NRC standards for radiation protection set out in 10 CFR 61.20 et seq., except for releases of radioactivity in effluents from the land disposal facility, which shall be governed by 10 CFR 61.41. Every reasonable effort shall be made to maintain radiation exposures as low as is reasonably achievable.

\section{A-2.1.4 Stability of the Disposal Site after Closure (10 CFR 61.44)}

The disposal facility must be sited, designed, used, operated, and closed to achieve long-term stability of the disposal site and to eliminate to the extent practicable the need for ongoing active maintenance of the disposal site following closure so that only surveillance, monitoring, or minor custodial care are required. The post-closure time period for which the disposal site must be stable is not specified.

Additional information is available with respect to guidance or recommendations for longer post-closure timeframes (e.g., 10,000 years). An Advisory Committee on Nuclear Waste letter report (Pomeroy et al. 1997) pointed out that no NRC regulatory requirement has been established regarding an LLW performance assessment timeframe. The draft NUREG-1573 Performance Assessment Methodology recommended a performance assessment timeframe of 10,000 years, a time sufficiently 
long to capture the peak dose to the critical population group. However, the Performance Assessment Working Group discussion regarding an appropriate timeframe for an LLW performance assessment was presented in the final published version of NUREG-1573 (NRC 2000) as guidance only (as summarized in NUREG-1853, NRC 2007). From a siting-study perspective, the most important NRC requirement is that "The disposal site shall be capable of being characterized, modeled, analyzed and monitored." This siting study incorporates a concept of "post-closure timeframe" in selection of criteria (including all the natural hazards as criteria) and in assignment of weighting and scoring factors (made with consideration of impacts that could occur over timeframes as long as 10,000 years). This approach incorporates qualitative assessment of longer timeframes in the siting process and still provides adequate screening in support of a performance assessment to be conducted later in the Critical Design process.

\section{A-2.2 10 CFR 61.50, Disposal Site Suitability Requirements for Land Disposal}

The NRC regulations for LLW disposal found at 10 CFR 61.50, "Disposal Site Suitability Requirements for Land Disposal," apply to facilities to be licensed by NRC. They are not directly applicable to DOE facilities but provide useful guidance and information for identifying siting criteria to evaluate candidate locations for new DOE LLW disposal facilities. The NRC guidance specifies the minimum site characteristics a site must have to be acceptable for use as a near-surface disposal facility. These details are quite useful in expanding DOE Manual 435.1-1 requirements cited above into criteria that can be assessed and evaluated. 10 CFR 61.50(1) states that Subpart D is designed to "...specify the minimum characteristics that a disposal site must have to be acceptable for use as a near-surface disposal facility." The criteria range from general (site must be capable of being characterized and monitored) to specific (site must avoid areas of faulting, folding, seismic, or volcanic activity). These details are quite useful in expanding DOE Manual 435.1-1 requirements cited above into criteria that can be assessed and evaluated. The following sections present the 10 characteristics or criteria of 10 CFR 61.50 .

\section{A-2.2.1 Characterization (10 CFR 61.50(2))}

The disposal site shall be capable of being characterized, modeled, analyzed, and monitored.

\section{A-2.2.2 Demographics Requirement (10 CFR 61.50(3))}

Within the region or state where the facility is to be located, a disposal site should be selected so that projected population growth and future developments are not likely to affect the ability of the disposal facility to meet the performance objectives of Subpart $\mathrm{C}$ of this part.

\section{A-2.2.3 Exploitable Natural Resources (10 CFR 61.50(4))}

Areas must be avoided having known natural resources which, if exploited, would result in failure to meet the performance objectives of Subpart $\mathrm{C}$ of this part.

\section{A-2.2.4 Surface Water Flooding or Ponding (10 CFR 61.50(5))}

The disposal site must be generally well drained and free of areas of flooding or frequent ponding. Waste disposal shall not take place in a 100-year flood plain, coastal high-hazard area or wetland, as defined in Executive Order 11988, "Floodplain Management Guidelines." 


\section{A-2.2.5 Surface Water Runoff (10 CFR 61.50(6))}

Upstream drainage areas must be minimized to decrease the amount of runoff that could erode or inundate waste disposal units.

\section{A-2.2.6 Depth to Water Table (10 CFR 61.50(7))}

The disposal site must provide sufficient depth to the water table that ground water intrusion, perennial or otherwise, into the waste will not occur. The NRC will consider an exception to this requirement to allow disposal below the water table if it can be conclusively shown that disposal site characteristics will result in molecular diffusion being the predominant means of radionuclide movement and the rate of movement will result in the performance objectives of Subpart $\mathrm{C}$ of this part being met. In no case will waste disposal be permitted in the zone of fluctuation of the water table.

\section{A-2.2.7 Groundwater Discharge to Surface (10 CFR 61.50(8))}

The hydrogeologic unit used for disposal shall not discharge ground water to the surface within the disposal site.

\section{A-2.2.8 Avoid Tectonically Active Areas (10 CFR 61.50(9))}

Areas must be avoided where tectonic processes such as faulting, folding, seismic activity, or volcanism may occur with such frequency and extent to significantly affect the ability of the disposal site to meet the performance objectives of Subpart $\mathrm{C}$ of this part, or may preclude defensible modeling and prediction of long-term impacts.

\section{A-2.2.9 Avoid Areas Subject to Erosion, Landslides, or Mass Wasting (10 CFR 61.50(10))}

Areas must be avoided where surface geologic processes such as mass wasting, erosion, slumping, landsliding, or weathering occur with such frequency and extent to significantly affect the ability of the disposal site to meet the performance objectives of Subpart $\mathrm{C}$ of this part, or may preclude defensible modeling and prediction of long-term impacts.

\section{A-2.2.10 Facility Interaction (10 CFR 61.50(11))}

The disposal site must not be located where nearby facilities or activities could adversely impact the ability of the site to meet the performance objectives of Subpart C of this part or significantly mask the environmental monitoring program.

\section{A-2.3 Clean Air Act}

Since the Remote-Handled LLW Disposal Facility will be used to manage only remote-handled LLW, any potential emissions would be associated with radionuclides and would be addressed under the requirements associated with the National Emission Standards for Hazardous Air Pollutants (NESHAPs). Emissions from operation of the facility are expected to be minimal and will be evaluated as part of the NEPA process.

\section{A-2.3.1 National Emission Standards for Hazardous Air Pollutants}

Section 112 of the Clean Air Act (PL 91-604) requires the Environmental Protection Agency (EPA) to regulate emissions of 187 hazardous air pollutants from a published list of industrial source 
categories. For these source categories, EPA has developed industry-specific technology requirements to control hazardous air pollutant emissions. These standards are known as NESHAPs. The EPA has developed eight NESHAPs that address emissions of radionuclides to the atmosphere.

The NESHAPS requirements are incorporated by reference in IDAPA 58.01.01.581, as follows: "The owner or operator of any stationary source shall comply with the 40 CFR Part 61 and 40 CFR Part 63 as applicable to the stationary source." The Idaho National Laboratory (INL) is subject to 40 CFR 61.90 through 61.97 , as stated, "The provisions of this subpart apply to operation of any facility owned or operated by the DOE that emits any radionuclide other than radon-222 and radon -220 into the air." 40 CFR 61.96 states that such a facility that has the potential for an unmitigated effective dose equivalent to a member of the public greater than or equal to $0.1 \mathrm{mrem} / \mathrm{yr}$, as calculated using the method in $40 \mathrm{CFR}$ 61 Appendix D, the owner or operator must submit an application to construct to EPA Region 10 and receive approval before construction begins.

\section{A-2.3.2 Clean Air Act Class I Areas}

The 1977 amendment to the Clean Air Act used the EPA three-class zoning system (i.e., Class I, Class II, and Class III), which provides for certain allowable increments of additional pollution in each. Section 162 defines all national parks and wilderness areas above a certain size $(5,000$ to 6,000 acres, depending on type of park) as Class I areas that cannot be re-designated. Section 169A defines a program for the "prevention of any future, and the remedying of any existing, impairment of visibility" in Class I areas from anthropogenic air pollution. In the vicinity of INL, Craters of the Moon National Monument, Yellowstone National Park, and Grand Teton National Park are designated Class I air quality areas. Development that impairs visibility in these areas will not be eligible for an air quality permit from the State of Idaho. In siting a remote-handled LLW disposal facility, a determination of potential emissions from the facility must be made and used to site the facility to prevent impairment to any Class I area. Class II and Class III areas will not impact siting at INL.

\section{A-2.4 Hazardous Waste Management Act/Resource Conservation and Recovery Act and Related Requirements}

The Resource Conservation and Recovery Act (RCRA) of 1976 (42 USC $\S 6901$ et seq.) amended the Solid Waste Act of 1965. In 1984, Congress passed the Hazardous and Solid Waste Amendments, which expanded the scope of the RCRA Program. Provisions of Subtitle C of RCRA, "Hazardous Waste Management" provide EPA and the State of Idaho with the authority to establish regulations for the identification and listing of hazardous waste and management standards applicable to the generation, transport and disposal of hazardous waste. RCRA regulations are enforced by the State of Idaho through the Hazardous Waste Management Act (HWMA).

Wastes subject to regulation under Subtitle C of RCRA are materials that meet the definition of a hazardous waste. The waste to be disposed of in the proposed facility is remote-handled LLW only and does not meet the definition of hazardous waste. Therefore, there are no RCRA-compliance requirements that pertain to the conceptual design of the Remote-Handled LLW Disposal Facility.

Subtitle D of HWMA/RCRA addresses non-hazardous solid waste. Pursuant to Subtitle D, EPA has set criteria for disposal of non-hazardous solid waste at municipal and non-municipal waste facilities. The remote-handled LLW activated metals and resins would not be considered household or municipal waste. It could be considered non-municipal waste. However, under the Idaho rules that implement the federal criteria, radioactive wastes regulated under the Atomic Energy Act are excluded from regulation (IDAPA 58.01.06.001.a.viii). Therefore, RCRA Subtitle D does not apply to this project. 


\section{A-2.5 Natural Resources Protection}

Federal laws and policies protect natural resources by discouraging development activities that could adversely affect protected plants, animals, or their habitat, or that could adversely affect air and water quality. Requirements include the Endangered Species Act of 1973, the Clean Air Act of 1970, the Clean Water Act of 1977, and Executive Orders on Protection of Wetlands and Floodplains. At INL, these requirements can be met by avoiding locating a disposal facility where it could affect protected natural resources and by minimizing unavoidable impacts to the extent possible. These requirements form the basis for developing siting criteria that avoid locating the disposal facility in an area that would have impacts on threatened and endangered species, air quality resources, and wetlands and floodplains.

\section{A-2.5.1 Endangered Species Act}

There are three designations given to species under the Endangered Species Act (ESA) of 1973, as amended (16 U.S.C. 1531 to 1534), which offer protection to plants and animals that have been found to warrant protective measures to ensure their survival and existence. These designations are endangered, threatened, or candidate species, as described below:

- An endangered species is an animal or plant species in danger of extinction throughout all or a significant portion of its range;

- A threatened species is an animal or plant species likely to become endangered within the foreseeable future throughout all or a significant portion of its range;

- A candidate species is a plant or animal species for which the United States Fish and Wildlife Service (USFWS) or the National Oceanic and Atmospheric Administration's National Marine Fisheries Service (NOAA fisheries) has on file sufficient information on biological vulnerability and threats to support a proposal to list it as endangered or threatened.

A species of concern is an informal term used by USFWS and NOAA fisheries and as many state agencies (i.e., the Idaho Department of Fish and Game) that refers to a species that might be in need of conservation action or is considered sensitive, rare, or declining on lists maintained by Natural Heritage Programs, state wildlife agencies, other federal agencies, or professional/academic scientific societies. This may range from a need for periodic monitoring of populations and threats to the species and its habitat, to the necessity for listing as threatened or endangered. Such species receive no legal protection and use of the term does not necessarily imply that a species will eventually be proposed for listing.

The ESA is intended to provide a means to conserve the ecosystems upon which endangered and threatened species depend and provide programs for the conservation of those species, thus preventing extinction of plants and animals. The law is administered by USFWS and NOAA Fisheries, depending on the species. Section 7 of the ESA requires all Federal agencies, in consultation with USFWS or NOAA Fisheries, to use their authorities to further the purpose of the ESA and to ensure that their actions are not likely to jeopardize the continued existence of listed species or result in destruction or adverse modification of critical habitat.

The interagency cooperation requirements of Section 7(a)(2) of the ESA are to be carried out in consultation with the Secretary of the Interior, via the USFWS. The need to initiate consultation is usually determined by the governing federal agency, which in the case of the Remote-Handled LLW Disposal Facility, is the DOE, and is based on an analysis to determine if an individual of a federally listed species, or its designated critical habitat, may be affected by a proposed action. The DOE must initiate consultation if a listed species is known, or suspected, to occur on land that will be affected by an action, 
and the DOE determines that individuals, populations, or designated critical habitat of threatened or endangered species may be affected by the action, either positively or negatively.

The consultation results in a biological opinion by USFWS or NOAA Fisheries determining whether the proposed action would jeopardize the continued existence of the species under consideration, or result in destruction or adverse modification of critical habitat. If jeopardy is not found, but some individuals may be incidentally killed as a result of the proposed action, the services can determine that such losses are acceptable if specified measures are followed.

\section{A-2.5.2 Wetlands and Floodplains}

The concept of a wetland is straightforward; it is an area transitional between dry land and open water. Because wetlands are environmentally valuable they have been the subject of various regulatory programs which may limit activities affecting them. The exact definition of what areas are wetlands, and thus potentially subject to regulation, is of great importance. For instance, Section 404 of the Clean Water Act (EPA 2007) regulates the discharge of dredged and fill materials into U.S. waters, including wetlands. The regulatory definition of wetlands is "Areas that are inundated or saturated by surface or ground water at a frequency and duration sufficient to support, and that under normal circumstances do support, a prevalence of vegetation typically adapted for life in saturated soil conditions. Wetlands generally include swamps, marshes, bogs, and similar areas" (33 CFR 328.3; 40 CFR 230.3). Placing exact bounds on what is and is not a wetland, as well as what does or does not constitute discharge of dredged or fill materials, has been the subject of great controversy. Regulated activities are controlled by a permit review process. The EPA and the U.S. Army Corps of Engineers (Corps) jointly administer the federal wetlands program.

Before DOE takes any action in a wetland for which a permit may be required, however, other regulatory requirements trigger detailed consideration and preservation of wetland values.

DOE regulations at 10 CFR 1022, "Compliance with Floodplain and Wetland Environmental Review Requirements” implement Executive Orders 11988 and 11990 for floodplain management and wetland protection. These regulations and executive orders require that any action in a wetland or floodplain must be undertaken in a manner that minimizes destruction, loss, or degradation of wetlands. Before the action, a floodplain/wetlands assessment must be prepared which describes the action, its effects, and alternatives considered. This is followed by a public review period during which federal and state regulatory agencies, such as EPA and the Corps, are notified of the proposed action and given the opportunity to comment. At the close of the comment period, DOE must reevaluate the action taking into account all comments received. If there is no practicable alternative to locating in wetlands or a floodplain, then DOE must design or modify the action to minimize potential harm to or within the wetlands or floodplain. To the extent possible, this review is carried out as part of the NEPA process.

Further, if the action involves discharge of dredged or fill materials in a wetland, then in addition to the requirements outlined above, a permit, either individual or general, from the Corps under Section 404 may be required (33 CFR 323). The Corps specifies the site of the discharge by applying guidelines known as the Section 404(b)(1) Guidelines, promulgated by EPA (40 CFR 230). The EPA has the power to prohibit or limit the use of a proposed disposal site under its regulations at 40 CFR 231.

\section{A-2.6 Historical, Tribal, and Cultural Resources Protection}

This subsection addresses federal laws and regulatory programs for the preservation of historical, tribal, and cultural resources. Federal laws addressing protection of archaeological, tribal and cultural resources include considerations for siting a disposal facility on federal land. Historic, tribal and cultural resources at federal facilities must be preserved and protected under laws including the Archaeological 
Resources Protection Act (16 U.S.C. 1B, 470aa et seq.), Native American Graves Protection and Repatriation Act (25 U.S.C. 32, 3001 et seq.), and the American Indian Religious Freedom Act (42 U.S.C. 21, 1996). These requirements are implemented through cultural resource investigations conducted as part of the NEPA process to assess impacts to such resources. The survey ensures that locations in an area that would disturb important historic, tribal, or cultural resources are avoided.

DOE recognizes its stewardship responsibilities for managing cultural resources on DOE-owned and other lands that are impacted by DOE programs. Concern for this public trust has prompted the development of a comprehensive cultural resources policy, DOE Policy 141.1, "Department of Energy Management of Cultural Resources," which requires implementation and maintenance of a Cultural Resource Management (CRM) program for all DOE facilities and programs. There are statutory and regulatory bases for this program and an Agency commitment to meet not only the letter but also the spirit of these laws and regulations. In addition, other DOE directives, such as DOE Order 450.1, "Environmental Protection Program" guide DOE's management and protection of cultural resources. This guide provides recommendations, alternatives, and approaches for implementing all those requirements.

The cultural resource planning process must be integrated into compliance actions driven by other environmental statutes such as the NEPA; the Comprehensive Environmental Response, Compensation, and Liability Act (CERCLA); and the Resource Conservation and Recovery Act. The DOE CRM program structure encompasses:

- $\quad$ Policy and guidance

- Planning

- Implementation

- $\quad$ Training and outreach

- Quality assurance

- Technical mission/environmental coordination.

This program encourages a proactive approach by DOE managers and their recognition of the cultural and scientific value of the resources that are under their jurisdiction.

Cultural resources include "historic properties" as defined in the National Historic Preservation Act (NHPA), "archaeological resource" as defined in the Archaeological Resources Protection Act, and "cultural items" as defined in the Native American Graves Protection and Repatriation Act. These federal laws and corresponding protected resources are discussed in the following subsections.

\section{A-2.6.1 National Historic Preservation Act}

The NHPA (16 U.S.C. 470 et seq.) was enacted to create a national historic preservation program, including the National Register of Historic Places (NRHP) and the Advisory Council on Historic Preservation. The NHPA provides for the placement of sites with significant national historic value on the NRHP. It requires no permits or certifications. 


\section{A-2.6.2 Archaeological and Historic Preservation Act}

The Archaeological and Historic Preservation Act (AHPA) of 1974, as amended (16 U.S.C. $469-469 \mathrm{c}$ ), provides for the preservation of historic and archaeological data that would otherwise be lost as a result of federal construction. The AHPA authorizes the U.S. Department of the Interior to undertake recovery, protection, and preservation of archaeological and historic data. Section 4(a) of the AHPA requires that the Secretary of the Interior be notified when unanticipated archaeological materials are discovered during construction of a federal project. Section 7(a) limits the amount of funds expended for archaeological data recovery to $1 \%$ of project expenses. Section 208 of the 1980 amendment of the NHPA establishes a procedure for agencies to request the Secretary of the Interior to waive the 1\% limitation. The AHPA would be applicable to construction of a remote-handled LLW disposal facility.

\section{A-2.6.3 Archaeological Resources Protection Act}

The Archaeological Resources Protection Act of 1979, as amended (16 U.S.C. 1B, 470aa et seq.) secures the protection of archeological resources and sites on public or Indian lands, and fosters exchange of information between agencies, organizations and individuals having collections or data. The Act requires individuals to obtain a permit from the federal land manager for any excavation or removal of archeological resources from public or Indian lands. Excavations must further archaeological knowledge in the public interest. Any resources removed remain the property of the United States. This Act would apply to activities associated with the construction of the proposed facility only in the event that activities affected archaeological resources at the construction site in a manner that created the potential for excavation or removal.

\section{A-2.6.4 American Antiquities Act}

The American Antiquities Act of 1906 (16 U.S.C. 431 et seq.) protects historic and prehistoric ruins, monuments, and objects of antiquity (including paleontological resources) on lands owned or controlled by the Federal Government. If historic or prehistoric ruins or objects were found during the construction of a remote-handled LLW disposal facility, a determination of whether adverse effects to these ruins or objects would occur. If adverse effects would occur, the Secretary of the Interior would have to grant permission to proceed.

\section{A-2.6.5 American Indian Religious Freedom Act}

The American Indian Religious Freedom Act (42 U.S.C. 21, 1996) affirms Native American religious freedom and establishes policy to protect and preserve the inherent and constitutional right of Native Americans to believe, express, and exercise their traditional religions. This law ensures the protection of sacred locations and access of Native Americans to those sacred locations and traditional resources that are integral to the practice of their religions. Further, it establishes requirements that would apply to Native American sacred locations, traditional resources, or traditional religious practices potentially affected by the construction and operation of projects requiring federal action.

The Act directed federal agencies to evaluate policies and procedures, consulting with native traditional religious leaders, to determine changes needed to implement the Act. One of the resulting changes was Executive Order 13007, "Indian Sacred Sites." This Order directs Federal agencies to avoid adverse effects to sacred sites and to provide access to those sites to Native Americans for religious practices to the extent permitted by law and not inconsistent with agency missions. Executive Order 13007 directs agencies to plan projects to provide protection of and access to sacred sites to the extent compatible with the project. 


\section{A-2.6.6 Native American Graves Protection and Repatriation Act}

The Native American Graves Protection and Repatriation Act of 1990 (25 U.S.C. 32, 3001 et seq.) directs the Secretary of the Interior to guide the repatriation of Federal archaeological collections and collections that are culturally affiliated with Native American tribes and held by museums that receive Federal funding. Major actions to be taken under this law include (1) the establishment of a review committee with monitoring and policymaking responsibilities, (2) the development of regulations for repatriation, including procedures for identifying lineal descent or cultural affiliation needed for claims, (3) the oversight of museum programs designed to meet the inventory requirements and deadlines of this law, and (4) the development of procedures to handle unexpected discoveries of graves or grave goods during activities on Federal or tribal land. The provisions of the Act would be invoked if any disposal facility-related excavations led to unexpected discoveries of Native American graves or grave artifacts.

\section{A-2.6.7 Executive Order 13175, Consultation and Coordination with Indian Tribal Governments}

Executive Order 17135, "Consultation and Coordination with Indian Tribal Governments," directs federal agencies to establish regular and meaningful consultation and collaboration with tribal governments in the development of Federal policies that have tribal implications, to strengthen U.S. government-to-government relationships with Indian tribes, and to reduce the imposition of unfunded mandates on tribal governments. Specifically, collaboration and consultation between the DOE and the Shoshone-Bannock Tribes is accomplished by the DOE/Tribal Interagency agreement. The agreement defines interface between DOE and the Shoshone-Bannock Tribes and provides a method for comment on the siting and construction of a remote-handled LLW disposal facility.

\section{A-2.7 State and Local Requirements}

No state or local requirements are associated with a remote-handled LLW disposal facility. It will be located on federal land. The facility will not manage waste that is defined as hazardous and is therefore not governed by state and federal hazardous waste management facility laws and regulations.

\section{A-3. FACILITY SPECIFIC REQUIREMENTS AND OBJECTIVES}

DOE Orders and federal or state laws/regulations establish the requirements for design and safe operation and closure of a remote-handled LLW disposal facility. Within the bounds of these requirements an iterative process is followed to apply the requirements to a specific facility designed to meet a specific mission need. This process starts with development of key assumptions, identification of conceptual design features, and identification of performance objectives needed to meet DOE requirements for protection of the public and the environment. Each of these areas results in more detailed requirements, many of which will have a bearing on a facility siting evaluation. The following sections review key assumptions, conceptual design objectives, and facility performance objectives as they relate to a siting evaluation.

\section{A-3.1 Key Assumptions}

Full development of the conceptual design required identifying a number of key assumptions. Of the 12 assumptions identified in the Conceptual Design Report for the facility, only four are directly applicable to the siting study. DOE Order 435.1, Radioactive Waste Management, specifies that the disposal facility must be able to accommodate the anticipated types and volumes of waste - one of the assumptions addresses this by identifying anticipated generators and annual volumes. The remaining two 
key assumptions are related to performance assessment. The three key assumptions that are applicable to this siting evaluation are identified below and reviewed in more detail in the following sections.

1. Activated metal waste volumes used for design purposes are $35 \mathrm{~m}^{3}$ per year from Naval Reactors Facility (NRF); $3 \mathrm{~m}^{3}$ every 8 years from the Advanced Test Reactor (ATR); and a total of $40 \mathrm{~m}^{3}$ from future missions, including waste stored at the Materials and Fuels Complex (MFC) Radioactive Scrap and Waste Facility (RSWF). Resin waste volumes used for design purposes are $8 \mathrm{~m}^{3}$ per year from NRF and $36 \mathrm{~m}^{3}$ per year from ATR.

2. The Performance Assessment characteristics of the selected site location will not result in more restrictive waste acceptance criteria for radioisotopic content than the current remote handled vault location.

3. A new Documented Safety Analysis Report, including a Performance Assessment, will be required for the Disposal Facility.

\section{A-3.1.1 Waste Volume}

The same key assumption that identified waste stream type also clearly specifies the anticipated generators and the annual disposal volume of activated metals and resins:

- $\quad$ Activated metal waste volumes used for design purposes are $35 \mathrm{~m}^{3}$ per year from the Naval Reactors Facility (NRF); a total of $40 \mathrm{~m}^{3}$ from future missions, including waste stored at the MFC RSWF; and $3 \mathrm{~m}^{3}$ every 8 years from the Advanced Test Reactor (ATR). Resin waste volumes used for design purposes are $8 \mathrm{~m}^{3}$ per year from the NRF and $36 \mathrm{~m}^{3}$ per year from the ATR.

Based on the annual waste production values noted in the assumption, it is anticipated that a total of $1,629 \mathrm{~m}^{3}$ will be generated over the lifetime of the disposal facility, which is initially planned for 20 years with room for expansion to accommodate future operations and missions. This volume, coupled with the vault design and required support infrastructure, will determine the area or footprint initially needed for the facility. The conceptual design discussed in the previous section integrates vault design and estimated waste volume to determine the area required for the facility. The projected area is at least 5 acres. For the purposes of the siting evaluation, an area of greater than 5 acres was set as a criterion.

\section{A-3.1.2 Waste Streams}

It is assumed that the only waste types that will be disposed in the Remote-Handled LLW Disposal Facility will be low-level-activated metals and ion-exchange resins only.

This is an important assumption because it affects the facility performance assessment. These waste forms and their confining containers are stable over long time periods and consequently isolate the radionuclides and limit release to the environment. Corrosion caused by seepage of water into disposal vaults is expected to be the primary degradation mechanism for the waste containers, and this leads to evaluation criteria that address the potential for saturating vaults with water (e.g., by flooding or groundwater intrusion). The inventory of waste will be an important element of a performance assessment but it does not have a significant impact on a siting evaluation. 


\section{A-3.1.3 Performance Assessment}

Two key assumptions address the need for a performance assessment:

1. The Performance Assessment characteristics of the selected site location will not result in more restrictive waste acceptance criteria for radioisotopic content than the current remote handled vault location.

2. A new Documented Safety Analysis/Safety Analysis Report, including a Performance Assessment and Composite Analysis, will be required for the Disposal Facility.

Performance assessment is an important component of siting, constructing, operating, and closing a remote-handled LLW disposal facility. Identifying site characteristics that result in a performance assessment that is no more restrictive than the current vault location (the Radioactive Waste Management Complex [RWMC]) imposes a number of constraints on site location. Two important elements of the performance assessment are evaluation of an "intruder," someone who may encounter waste through excavation or drilling, and radionuclide release and subsequent migration to a receptor. The siting evaluation addresses the radionuclide migration issue while design addresses the intruder issue. A full evaluation of performance assessment is given in Section A-3.3. Compliance with the performance objectives of DOE Order 435.1 will be demonstrated through the Performance Assessment and Composite Analysis documentation and issuance of a disposal authorization statement from DOE-HQ. These analyses may determine the need for additional and/or revised design requirements.

\section{A-3.2 Conceptual Design Objectives}

A remote-handled LLW disposal facility will provide a solution for disposition of INL's remotehandled activated metal and ion-exchange resin LLW generated through at least year 2037. The conceptual design for this facility uses a series of vertical concrete vaults to accommodate the estimated remote-handled LLW quantities (TFR-483). The concrete vault system will be designed such that the existing cask liner placement systems and processes currently implemented at RWMC can continue to be utilized. Meeting this objective will ensure that disposal of the future projected waste volume generated at various INL facilities can continue while maintaining consistency in waste disposal operations and procedures, thus providing minimal operational impacts to the generating facilities. Figure A-1 shows a cross-section of the vault design currently used at the RWMC. 


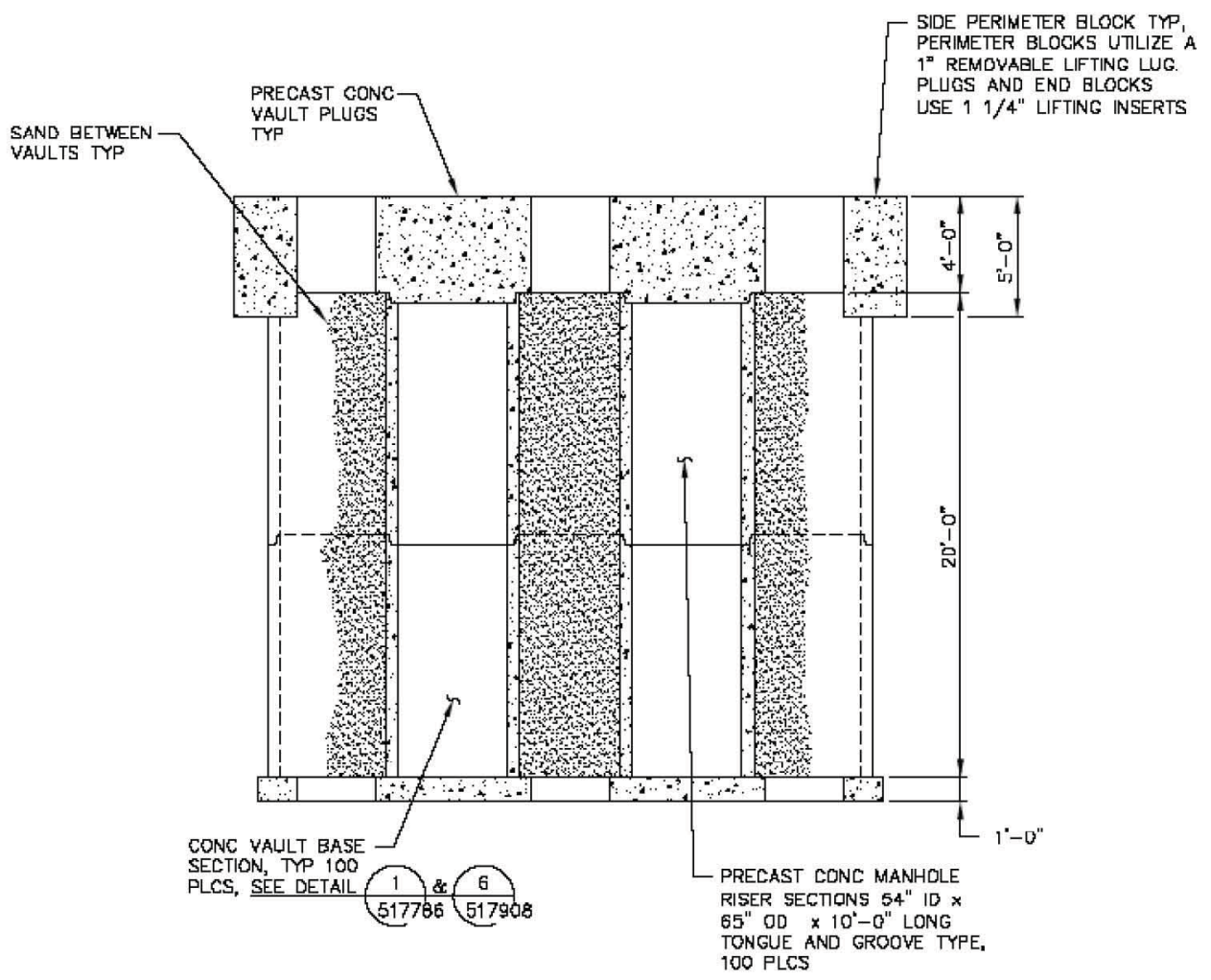

Figure A-1. Radioactive Waste Management Complex conceptual vault design.

Conceptual design objectives that impact the facility siting evaluation are derived from the technical and functional requirements (T\&FR) specified for the facility (TFR-483). Only a subset of the T\&FRs will be related to evaluating site suitability. Elements of the T\&FR that should be considered during a siting evaluation include size (area and depth), support infrastructure, and design/construction considerations.

\section{A-3.2.1 Disposal Facility Size Requirements}

Three different sized concrete vaults are envisioned for use in the new on-Site facility. The first vault configuration is based directly on the RWMC vaults, which are suitable for the 55-ton cask liner used by NRF for transport of remote-handled LLW. Each vault is comprised of $10-\mathrm{ft}$ sections of pre-cast concrete pipe, stacked on end, for a total interior height sufficient to accommodate two cask liners. The vaults have a circular cross section and are approximately $4.5 \mathrm{ft}$ in diameter and $20 \mathrm{ft}$ high. These vaults can accommodate two stacked 55 -ton cask liners $(4 \mathrm{ft}$ diameter $\times 8.6 \mathrm{ft}$ high). Each liner holds approximately $106 \mathrm{ft}^{3}$ of waste. The number of vaults of this type required is determined by the planned shipping schedule from the generator facilities. The projected annual average quantity of remote-handled LLW activated metals and resins from the NRF is $1,518 \mathrm{ft}^{3}$. In order to accommodate the generated volume for an assumed 20-year operational period, approximately 160 vaults will be required.

The second vault configuration is based on the configurations of the containers used by ATR for transport of remote-handled LLW resins. These vaults will be constructed of pre-cast concrete pipe sections approximately $7 \mathrm{ft}$ in diameter and $8 \mathrm{ft}$ high. These vaults are larger to accommodate the $\mathrm{NuPac}^{\mathbf{T M}}$ liners used to transport ATR resin wastes. Each vault can hold two liners; each liner holding approximately $212 \mathrm{ft}^{3}$ of waste resin. To accommodate approximately six planned shipments per year, 60 vaults of this type will be required. 
The third vault configuration is based on the assumed configuration of the containers to be used by ATR and other generators such as MFC for transport of remote-handled LLW activated metals. It is assumed that this activated metal waste will be transported in a commercially available cask. Cask liners would be approximately $3 \mathrm{ft}$ in diameter and $9.25 \mathrm{ft}$ high, each holding approximately $53 \mathrm{ft}^{3}$ of waste. These vaults are configured similar to the NRF vaults in regard to access and surface configuration. Each vault is comprised of $10-\mathrm{ft}$ sections of pre-cast concrete pipe, stacked on end, for a total interior height sufficient to accommodate two cask liners. These vaults will have an approximate inside diameter of $4 \mathrm{ft}$. Twenty-four vaults of this design will be required over the 20 -year life of the facility.

In total, approximately 244 vaults of three different designs will be required in the new facility to dispose of all INL-generated remote-handled LLW through FY 2037.

The existing RWMC remote-handled LLW concrete vault and plug system accommodates two vertically stacked 55-ton cask liners that are received from NRF. The conceptual design allows the option for the new vault system to be configured to allow either two or three liners to be placed within each vertical vault. The ability to provide the three-liner disposal configuration is dependent on the available depth of surface sediments present at the siting location. Thus one conceptual design requirement is knowledge of the depth of surficial sediments to support design and operations flexibility.

Combining waste container configuration with estimated waste streams and disposal vault configuration and with the potential need for expansion, indicates that a total area of approximately 5 acres will be needed to accommodate the proposed LLW disposal facility. Also included in the facility design will be an administrative building, a maintenance building, miscellaneous storage pads, access roads and perimeter fencing.

\section{A-3.2.2 Support Infrastructure Requirements}

The primary utility needed to operate the new facility will be electrical power. At the present time, a portable generator is used to power all the unloading and waste placement operations. Operations at the new facility could continue to use the portable generator, however the conceptual design is assuming that power will provided as part of the project. Power will be needed for the support infrastructure that is currently provided by other RWMC facilities. Other power needs include the administrative building equipment maintenance and staging, and site control and monitoring capabilities. Location near an existing power source is a benefit but not necessarily a requirement for facility siting. Other utilities (i.e., telecommunication) are also included in the conceptual design. Neither a water supply nor sanitary sewer are needed at the site in order to meet the identified technical and functional requirements.

Road access must be provided that will allow the transport of the loaded cask vehicles. A haul route will be identified or designed that will provide for the passage of anticipated cask transport loads without damaging any existing infrastructure. Damage to existing roadways can be avoided in various ways, including constructing new roads, upgrading existing roads, and limiting vehicle weights to conform to existing roadway load limits. The truck turning radius, maneuverability, unloading positioning, and drive slopes will also be taken into consideration when determining the haul route alignment. The site area will be sufficient to design appropriate road access for transport loads and vehicles within the Disposal Facility. The siting study evaluation should consider distance from the facility to existing haul routes to identify the length of new access roads needed to connect the facility to existing roads. 


\section{A-3.2.3 Design/Construction Requirements}

The primary design and construction element that drives identification of siting evaluation criteria is the determination of the structure, systems, and components (SSC) performance category (PC). In the case of the remote-handled LLW disposal facility, the SSCs that are evaluated are the vaults and any support buildings. The PC determination sets the level of characterization needed for NPH assessment. If the performance category is high enough, the qualitative characterization data available at the siting evaluation step may be used to identify locations that may be unsuitable from a NPH perspective (e.g., at INL, seismic or volcanic hazards). There is an iterative evaluation between the design process and NPH assessment to evaluate the cost effectiveness of NPH mitigation through design (the graded approach from DOE Order 420.1B).

Guidance for determination of the performance category is provided in DOE-STD-1021-93, "Natural Phenomena Hazards Performance Categorization Guidelines for Structures, Systems, and Components." The application of the basic categorization guidelines presented in Section 2.4 establishes the preliminary performance category of SSCs. The preliminary performance category may not account for system interactions and it is recognized that the determination of the performance category is an iterative process with both the Safety Analysis and NPH characterization activities conducted after the preferred site is selected through the NEPA process. It is to be noted that the hazard categorization is based on a method for assessing risk from potential hazards and follows the graded approach discussed in the NPH Implementation Guide for DOE Order 420.1 (DOE Guide 420.1-2).

Applying the guidance from DOE-STD-1021-93 leads to a determination that the LLW disposal facility will be designed, constructed, and operated under a preliminary Performance Category 1 (PC-1) designation. This $\mathrm{PC}-1$ designation is equivalent to a facility category of SDC-2 when using the evaluation criteria specified in DOE-STD-1189-2008. This determination will be further evaluated and developed as part of the PDSA, with any changes incorporated into the Final Facility Design. The basis for this designation is as follows:

1. The primary components of this facility related to safety are the pre-cast concrete disposal vaults.

2. The draft preliminary hazard analysis for this facility identifies a Hazard Category of Hazard Category 2 (HC-2).

3. The vaults are located below ground level, isolated from facility workers, and therefore will not impose any risk of fatality or serious injury to workers.

4. No failure will result in a loss of function of an emergency system needed to preserve the health and safety of workers

5. If the vaults were to fail there would be no off-site consequences.

6. Support facilities for this facility will normally be unoccupied. The facility will have building and a maintenance structure that has potential for human occupancy, but neither of which will be used or associated with facility waste disposal operations.

7. The failure of a concrete vault may cause the overall disposal capacity to be reduced, thus requiring the need to install additional vaults to replace damaged vaults in the future.

Further evaluation regarding the performance category will be completed during future safety analyses in accordance with procedure NS-18101, INL Safety Analysis Process. These analyses will be 
documented in the Preliminary Documented Safety Analysis, the Documented Safety Analysis and the Safety Analysis Reports.

\section{A-3.3 Facility Performance Objectives}

Ensuring that a remote-handled LLW disposal facility meets its performance objectives requires an assessment of the consequences of facility failure due to natural phenomena or simple deterioration over time. The primary consequence of disposal facility failure is release of radionuclides to the environment. To evaluate the hazard associated with this potential release a performance assessment calculation and analysis is conducted as an integral part of design and operation of the remote-handled LLW disposal facility. The calculations involve modeling the transport of radionuclides from buried waste to surface soil and subsurface media, and eventually to members of the public via air, groundwater, and food chain pathways. Estimated dose is calculated for both off-Site receptors and individuals who inadvertently intrude into the waste after site closure. The results of the calculations are used to evaluate the future performance of the disposal facility.

Detailed performance assessment calculations are not conducted as part of the siting evaluation. When considering candidate site locations the evaluation includes assessment of the parameters needed to support analysis of receptor exposure via the air, groundwater, or ingestion pathways. The evaluation also considers, to the extent practicable using existing information, the suitability of a candidate site with respect to NPHs. Compliance with the performance objectives of DOE Order 435.1 will be demonstrated through the Performance Assessment and Composite Assessment documentation and issuance of a disposal authorization statement from DOE-HQ. These analyses may determine the need for additional and/or revised design requirements. The following sections identify performance objectives specified in DOE Orders 435.1 and 420.1 and further identify specific site characteristics that should be considered during the siting evaluation process.

\section{A-3.3.1 Protection of the Public}

A performance assessment is "an analysis of a radioactive waste disposal facility conducted to demonstrate there is a reasonable expectation that performance objectives established for the long-term protection of the public and the environment will not be exceeded following closure of the facility" (DOE Order 435.1). Performance objectives include public and intruder radiological dose limits and drinking water radiological dose limits established by DOE orders. In the context of the siting evaluation for the remote-handled LLW disposal facility, the waste management system consists of the proposed disposal of activated metals and resins, the remote-handled LLW disposal facility, and its environs. The radiological performance objectives that must be met are:

1. Effective dose equivalent to representative members of the public less than $25 \mathrm{mrem} / \mathrm{yr}$ from all pathways

2. Effective dose equivalent to representative members of the public less than $10 \mathrm{mrem} / \mathrm{yr}$ via air pathways

3. Radon less than $20 \mathrm{pCi} / \mathrm{m}^{2}$-s average flux at the surface.

The radiological performance assessment is a tool used to predict the potential environmental consequences of the disposal facility; its intent is to determine whether waste management activities will accomplish the goal of effectively containing LLW. This goal is accomplished if compliance with performance objectives is demonstrated in the performance assessment. The performance assessment includes calculations for a 1,000-year period after closure of potential doses to representative future 
members of the public and potential releases from the facility (DOE Manual 435.1 IV P(2)) The performance assessment is then used to establish the limits on the concentrations of radionuclides that can be disposed.

\section{A-3.3.2 Siting Requirements}

Specific siting requirements related to performance assessment are contained in DOE Manual 435.1-1 and DOE Guide 435.1-1, Implementation Guide for Use with DOE M 435.1-1. Requirements related to the siting of a new remote-handled LLW disposal facility are listed below.

- $\quad$ Performance assessments shall address reasonably foreseeable natural processes that might disrupt barriers against release and transport of radioactive materials.

- Performance assessments shall include an assessment of impacts to water resources.

- $\quad$ Performance assessments shall include an assessment of impacts calculated for a hypothetical person assumed to inadvertently intrude for a temporary period into the Remote-Handled LLW Disposal Facility.

The objective of these requirements is to ensure that all aspects of LLW disposal (i.e., facility siting, design, operations, maintenance, and eventual closure) are analyzed in a performance assessment to provide a reasonable expectation that the facility performance objectives will be met. At the facility siting stage, the objective is to determine site characteristics that allow a relative ranking of candidate locations with respect to barrier integrity and the site characteristics that may enhance attenuation of radionuclide migration through the environment.

\section{A-3.3.3 Radionuclide Performance Assessment}

The primary radiological performance assessment input data that should be considered at the siting evaluation stage are fundamentally based on site characteristics that provide time for radioactive decay to occur, thereby lowering dose to a receptor. Retardation time can be extended through facility design as well as by the nature of the material through which radionuclide migration may occur. Table A-1 outlines the various performance assessment elements contributing to dose calculation and identifies the specific characterization criteria that provide data for the assessment.

Table A-1. Site-specific data needed to support radionuclide performance assessment.

\begin{tabular}{lll}
\multicolumn{1}{c}{ PA Parameter } & \multicolumn{1}{c}{ Input Data } & \multicolumn{1}{c}{ Comment } \\
\hline $\begin{array}{l}\text { Retardation in waste } \\
\text { material }\end{array}$ & $\begin{array}{l}\text { Waste composition and } \\
\text { physical form }\end{array}$ & $\begin{array}{l}\text { Activated metals and resins are stable } \\
\text { over long time periods }\end{array}$ \\
$\begin{array}{l}\text { Thickness of disposal } \\
\text { facility }\end{array}$ & Sediment thickness & $\begin{array}{l}\text { Sediment (Interbed) thickness and } \\
\text { properties impact contaminant migration }\end{array}$ \\
Infiltration rate & Precipitation & $\begin{array}{l}\text { Meteorological data similar across INL, } \\
\text { cover design may reduce infiltration }\end{array}$ \\
$\begin{array}{l}\text { Retardation in vadose } \\
\text { zone }\end{array}$ & Interbed thickness & $\begin{array}{l}\text { Sediment (Interbed) thickness and } \\
\text { properties impact contaminant migration }\end{array}$ \\
\hline
\end{tabular}




\begin{tabular}{lll}
\hline \multicolumn{1}{c}{ PA Parameter } & \multicolumn{1}{c}{ Input Data } & \multicolumn{1}{c}{ Comment } \\
\hline $\begin{array}{l}\text { Distance through vadose } \\
\text { zone }\end{array}$ & Depth to aquifer & $\begin{array}{l}\text { Longer vadose zone path = longer travel } \\
\text { time results in more radioactive decay, } \\
\text { lower dose }\end{array}$ \\
$\begin{array}{l}\text { Water flux through } \\
\text { vadose zone }\end{array}$ & Precipitation & $\begin{array}{l}\text { Evapotranspiration losses lower flux, } \\
\text { data will be similar across INL }\end{array}$ \\
$\begin{array}{l}\text { Dispersion in vadose } \\
\text { zone }\end{array}$ & $\begin{array}{l}\text { Physical characteristics } \\
\text { (e.g., basalt fractures/rubble } \\
\text { zones, grain size within } \\
\text { interbeds) }\end{array}$ & $\begin{array}{l}\text { Generally considered to be the same } \\
\text { across INL }\end{array}$ \\
$\begin{array}{l}\text { Water flux through the } \\
\text { aquifer }\end{array}$ & $\begin{array}{l}\text { Hydraulic conductivity and } \\
\text { hydraulic gradient }\end{array}$ & $\begin{array}{l}\text { Higher flux results in lower concentration } \\
\text { and lower dose }\end{array}$ \\
Future land use & Industrial or Residential & Residential use requires intruder analysis \\
\hline
\end{tabular}

Review of the input data shown in Table A-1 indicates that there are three general areas that contribute to development of specific siting evaluation criteria: (1) waste stream characteristics, (2) geological characteristics, and (3) meteorological conditions. Of the three, waste stream characteristics and meteorology across INL are well defined and will not lead to criteria that might distinguish one site from another. The geological characteristics of a site, on the other hand, are variable across INL and they may have significant influence on criteria developed to evaluate relative long-term performance of radionuclide migration from a facility. The geological characteristics also will contribute to evaluation of NPHs. Criteria that are used to evaluate geologic characteristics are presented in Appendix B.

\section{A-3.3.4 Natural Phenomena Hazards Assessment}

Depending on the nature of the facility (e.g., reactor vs. disposal facility), additional assessments may be required to evaluate the impact of natural phenomena events on system design and long-term performance objectives. The objective of chapter IV of DOE Order 420.1B is to establish requirements for DOE facility design, construction, and operations that protect the public, workers, and the environment from the impact of all NPH events (e.g., earthquake, wind, flood, and lightning). In the case of a remote-handled LLW disposal facility at INL, seismic and flooding events represent the two most significant NPHs. The annual probability of lava inundation is much less than that for ground shaking from a seismic event, but the consequences are more serious. With proper design and construction, the facility can be constructed to accommodate inundation.

DOE Order 420.1B requires facility design and evaluation criteria that address the potential types of NPH occurrences. An NPH assessment for a new facility must use a graded approach that is commensurate with the potential hazard of the facility and that considers the consequences of all types of NPHs. The following paragraphs summarize the requirements for seismic and flood hazard assessment for the remote-handled LLW disposal facility.

Seismic Hazard Performance Evaluation-As described in DOE-STD-1020-2002, Natural Phenomena Hazards Design and Evaluation Criteria for Department of Energy Facilities, criteria are provided for each of the four performance categories (PC 1 to 4), as defined in DOE Order 420.1B, the 
accompanying Guide DOE Guide 420.1-2, and DOE-STD-1021-93, Natural Phenomena Hazards Performance Categorization Guidelines for Structures, Systems and Components. The criteria for PC-1 and $\mathrm{PC}-2$ are similar to those from model building codes.

The earlier standard, DOE-STD-1020-94, adopted the Uniform Building Code (UBC) for the seismic design and evaluation of PC-1 and PC-2 structures. As noted in the updated DOE-STD-10202002, the International Building Code (IBC) became the accepted standard in place of the UBC for DOE facilities. The IBC seismic hazard is represented on maps that describe the hazard in terms of the maximum considered earthquake (MCE) ground motions. Except for locations on or near very active known faults, the maps contain accelerations that are associated with a 2,500-year return period earthquake. The ground motions associated with the MCE as modified by the site conditions are used for the design and evaluation of PC-1 and PC-2 structures in this revised DOE standard. Site conditions include lithology and thickness of surficial sediments. The graded approach is maintained by applying a two-thirds factor for PC-1 facilities, and a factor of unity for PC-2 facilities. The preliminary designation for the Remote-Handled LLW Disposal Facility is PC-1, which requires application of IBC Seismic Group I design standards. Seismic hazard is evaluated in Appendix B of this report through application of both a "Must" and a "Want" criterion.

DOE-STD-1189, Integration of Safety into the Design Process implements two new seismic design standards that are intended to supplement DOE-STD-1020 and DOE-STD-1021. These new standards are:

- $\quad$ ASCE/SEI 43-05, "Seismic Design Criteria for Structures, Systems and Components in Nuclear Facilities"

- $\quad$ ANSI/ANS-2.26-2004, "Categorization of Nuclear Facility Structures, Systems, and Components for Seismic Design."

These new standards describe an alternative methodology for assigning a hazard category to a new nuclear facility (ANSI/ANS-2.26) and developing engineering requirements commensurate with the hazard (ASCE/SEI 43-05). The methods roughly parallel the original standards beginning with the assignment of a Design Basis Earthquake (DBE) according to hazard category that is comparable to the assignment made by DOE-STD-1020 and DOE-STD-1021 (Table A-2). For the level of analysis performed at the LLW disposal facility preliminary siting stage, the new standards do not change the choice or weighting of seismic-related site selection criteria. The PC-1 designation under DOE-STD-1020 correlates to a Seismic Design Category (SDC)-2 under the new standards.

Table A-2. Comparison of facility category and associated design basis earthquake, as described in DOE-STD-1020, DOE-STD-1021, and ANSI/ANS-2.26, ASCE/SEI 43-05.

\begin{tabular}{l|c|c|c|c}
\hline \multirow{2}{*}{ Relative Hazard } & \multicolumn{2}{|c|}{ DOE-STD-1020, DOE-STD-1021 } & \multicolumn{2}{c}{ ANSI/ANS-2.25, ASCE/SEI 43-05 } \\
\cline { 2 - 5 } Low & Category & DBE Probability & Category & DBE Probability \\
\cline { 2 - 5 } & PC-0 & None & SDC-1 & $4 \times 10^{-4}$ \\
& PC-1 & $4 \times 10^{-4}$ & SDC-2 & $4 \times 10^{-4}$ \\
& PC-2 & $4 \times 10^{-4}$ & SDC-3 & $4 \times 10^{-4}$ \\
& PC-3 & $4 \times 10^{-4}$ & SDC-4 & $4 \times 10^{-4}$ \\
High & PC-4 & $1 \times 10^{-4}$ & SDC-5 & $1 \times 10^{-4}$ \\
\hline
\end{tabular}


3.3.4.1 Flooding Hazard Performance Evaluation-As outlined in DOE-STD-1020-2002, the flood design and evaluation criteria seek to ensure that safety SSCs at DOE sites satisfy the performance goals described in Appendices B and C of that standard. Table A-3 summarizes flood criteria for the four performance categories. These criteria define the type of data used for flood hazard analysis input, the mean hazard annual probability, the design requirements, and the actions to be implemented through emergency operation plans.

Table A-3. Flood criteria summary (from DOE-STD-1020-2002).

\begin{tabular}{l|l|c|c|c}
\hline \multirow{2}{*}{ Item } & \multicolumn{4}{|c}{ Performance Category } \\
\cline { 2 - 5 } $\begin{array}{l}\text { Flood Hazard } \\
\text { Input }\end{array}$ & $\begin{array}{l}\text { Flood insurance } \\
\text { studies or } \\
\text { equivalent input }\end{array}$ & $\begin{array}{l}\text { Site probabilistic } \\
\text { hazard analysis }\end{array}$ & $\begin{array}{l}\text { Site probabilistic } \\
\text { hazard analysis }\end{array}$ & $\begin{array}{l}\text { Site probabilistic } \\
\text { hazard analysis }\end{array}$ \\
\hline $\begin{array}{l}\text { Mean Hazard } \\
\text { Annual } \\
\text { Probability }\end{array}$ & $2 \times 10^{-3}$ & $5 \times 10^{-4}$ & $1 \times 10^{-4}$ & $1 \times 10^{-5}$ \\
\hline $\begin{array}{l}\text { Design } \\
\text { Requirements }\end{array}$ & $\begin{array}{l}\text { Applicable criteria (e.g., governing local regulations [IBC 2000]) shall be used for } \\
\text { building design for flood loads (i.e., load factors and design allowances), roof design } \\
\text { and site drainage. The design of flood mitigation systems (i.e., levees and dams) shall } \\
\text { comply with applicable standards as referred to in these criteria. }\end{array}$ \\
\hline $\begin{array}{l}\text { Emergency } \\
\text { Operation }\end{array}$ & $\begin{array}{l}\text { Required to } \\
\text { evacuate on-site } \\
\text { personnel if } \\
\text { facility is } \\
\text { impacted by the } \\
\text { design basis } \\
\text { flood (DBFL) }\end{array}$ & $\begin{array}{l}\text { Required to } \\
\text { evacuate on-site } \\
\text { personnel and to } \\
\text { secure vulnerable } \\
\text { areas if site is } \\
\text { impacted by the } \\
\text { DBFL }\end{array}$ & $\begin{array}{l}\text { Required to evacuate } \\
\text { on-site personnel not } \\
\text { involved in essential } \\
\text { operations. Provide } \\
\text { for an extended stay } \\
\text { for personnel who } \\
\text { remain }\end{array}$ & $\begin{array}{l}\text { Procedures must be } \\
\text { established to secure } \\
\text { the facility during } \\
\text { the flood such that } \\
\text { operations may } \\
\text { continue following } \\
\text { the event. }\end{array}$ \\
\hline
\end{tabular}

A flooding hazard evaluation for a PC-1 facility is based on a mean hazard annual probability of $2 \times 10-3$, equivalent to a 500-year flood, in accordance with DOE Standard - Natural Phenomena Hazards Design and Evaluation Criteria for Department of Energy Facilities - Table 4.1 (DOE-STD1020-2002). The flood hazard input can be derived from flood insurance studies or their equivalent. Flood insurance studies have been conducted for areas along the Big Lost River upstream from INL but have not been conducted on INL. However, the Bureau of Reclamation (BOR) conducted an equivalent study (Ostenaa and O'Connell 2005) that provides inundation maps at different flood recurrence intervals (including the 500-year flood) for the Big Lost River channel extending from the spreading area diversion to approximately $3 \mathrm{mi}$ downstream from the Idaho Nuclear Technology and Engineering Center (INTEC) and RTC. Flood volumes include an estimate of the design basis flood for a PC 1 facility, equivalent to the 500-year flood volume. No inundation maps are available for the 500-year flood downstream from the BOR study. The remote-handled LLW disposal facility is designated PC-1 and requires identification of the 500-year floodplain and incorporation of evacuation routes and procedures for the facility. Appendix B includes both a "Must" and "Want" criterion that addresses the 500-year flood hazard.

3.3.4.2 Volcanic Hazard Performance Evaluation-Recent volcanism has occurred on the eastern Snake River Plain. Basalt flows exposed on the surface at and near INL are as young as several thousand years. The potential exists for future volcanism and lava inundation at INL sites. Little guidance exists regarding assessment of volcanic hazards. DOE Standard 1022-94 (1996) stated that volcanism 
does not pose a significant hazard in most places within the United States. This standard also noted that the likelihood of renewed volcanic activity and the associated potential hazards shall be assessed in those regions where recent (Quaternary) volcanic activity has occurred. This standard states that no volcanic hazard assessment standard currently is available and that DOE should approve any approach in those few cases where such assessment is required. The annual probability of lava inundation is much less than that for ground shaking from a seismic event. With proper design and construction, the facility can be constructed to accommodate inundation.

\section{A-4. PREVIOUS INL SITING STUDIES}

Selection of a candidate location for on-site LLW disposal at INL is subject to the requirements of DOE Order 435.1 and implementing guidance for LLW facilities. A siting evaluation must consider environmental characteristics, geotechnical characteristics, and impacts to or from human activities. The siting study is a significant and early step in the process of extending INL's capability to meet the LLW disposal needs of its mission. Numerous siting studies have been conducted at INL, resulting in definition of appropriate siting criteria, development of evaluation strategies, and compilation of detailed information about candidate sites within the INL boundary.

Several such studies have been prepared to support evaluation of proposed INL LLW disposal facilities, treatment facilities, and nuclear reactors. In addition to the siting studies, there are also substantial data regarding site conditions available from environmental monitoring, sampling and analysis, and other activities performed at INL. Four of the available siting studies are reviewed below to provide a background for the current work. The four studies and the corresponding references are:

- High-Level Waste Treatment and Interim Storage Facility and LLW Landfill-Preliminary Evaluation of Potential Locations on the Idaho National Engineering and Environmental Laboratory for a High-Level Waste Treatment and Interim Storage Facility and a Low-Level Waste Landfill (Holdren et al. 1997).

- New Production Reactor-Site Selection Report for the New Production Reactor at the Idaho National Engineering Laboratory (Spry et al. 1989).

- New Waste Handling Facilities at the INEL-Preliminary Siting Activities for New Waste Handling Facilities at the Idaho National Engineering Laboratory (Taylor et al. 1994).

- Idaho CERCLA Disposal Facility (ICDF) - Final Record of Decision Idaho Nuclear Technology and Engineering Center Operable Unit 3-13 (DOE-ID 1999).

A brief summary of these four studies is provided below to document the depth of evaluation that has already been performed and demonstrate the adequacy of using this information to facilitate a time and cost effective siting evaluation for the remote-handled LLW disposal facility. For brevity, only the "Must" criteria are presented here (see Section 2.1 of the Siting Evaluation Report for a definition of "Must" criteria). Additional "Must" and "Want" criteria are considered in detail in Appendix B.

\section{A-4.1 Low-Level Waste Landfill}

A study conducted in 1997 evaluated candidate locations at INL for disposition of calcined waste and liquid sodium-bearing waste stored at INTEC (Holdren et al. 1997). Several treatment options were considered, including construction of a treatment facility to process the calcine into a physical form that would comply with waste acceptance criteria (WAC) and shipping requirements. A variation of the 
treatment option considered separating the waste into high-level and low-level fractions. The high-level fraction would comply with WAC for a federal repository while the low-level component could be permanently disposed of in a landfill. The study identified and evaluated sites for both a high-level waste treatment and interim storage facility and a LLW landfill. The study screened 16 sites for the LLW landfill according to four "Must" criteria:

- $\quad$ Avoid the 100-year floodplain

- $\quad$ Avoid wetlands

- Avoid critical habitat of endangered species

- Avoid areas in which tectonic processes may affect ability of the facility to meet performance objectives or may preclude defensible prediction of long-term impacts.

Sites that met all of the above criteria were assessed for 19 additional "want" criteria that addressed minimizing impacts to resources, accessibility, suitability for waste volume and expansion, and impeding downward migration of contamination. A scoring system based on weighted criteria was used to rank the sites. The study identified several alternative remote-handled LLW disposal facility locations with similar suitability ratings. The LLW Disposal Facility component of this report serves as the best reference for details applicable to the Remote-Handled LLW Disposal Project facility siting evaluation. Appendix B includes a summary of all the "Must" and "Want" Criteria from this report, integrates them with criteria from the other three studies, and screens them for applicability to this siting study.

\section{A-4.2 New Production Reactor}

The need for a new tritium and plutonium production facility was identified in the early $1980 \mathrm{~s}$. To meet this need, DOE proposed deployment of a New Production Reactor (NPR), and in 1983, a site selection was performed by the Department of Energy Idaho Operations Office for the NPR at INL, one of three DOE reservations considered for the facility. The site selection process used Kepner-Tregoe Decision Analysis to separate siting criteria into "Musts" (defined as minimum or critical requirements) and "Wants" (defined as differentiating criteria). The "Must" requirements included:

- $\quad$ Five miles from capable faults

- Outside a volcanic exclusionary zone (5 mi for vents in rift zones and $3 \mathrm{mi}$ for vents outside of rift zones)

- $\quad$ Above the probable maximum flood due to Mackay Dam failure on the Big Lost River

- $\quad$ Meet 10 CFR 100 population density limits

- $\quad$ One square mile or more in area

- $\quad$ Environmentally acceptable (would not involve unique habitat or destroy endangered species)

- Water availability of approximately 30,050 acre-feet per year (18,600 gallons per minute).

Sites that did not meet all the above minimum requirements were eliminated from further consideration. The remaining sites were evaluated against 14 differentiating or "Want" criteria, which were weighted according to relative importance. This process yielded six candidate sites. The top four 
sites were recommended in declining order of acceptability, as locations for siting the NPR at INL. Site "E," the site with the highest numerical ranking score, was located near INTEC where fuel processing for the NPR would occur. This site was also close to established roads, the railroad, and the INL electrical transmission loop, which would minimize construction costs. A facility interaction analysis (collocation accident analyses) assessed collocation impacts of the NPR with other INL facilities and showed that the NPR could safely be collocated near INTEC, Power Burst Facility, and Auxiliary Reactor Area.

The NPR site selection process and results were summarized and reviewed in 1989 (Spry et al. 1989) to determine if the primary site selected in 1983 was still considered the best site in light of recent site characterization data. The review indicated that appropriate factors were considered, including applicable NRC guidance and cost and environmental concerns. The review confirmed the suitability of the selected primary location based on the latest available geological, tectonic, hydrological, archaeological, and ecological results. This siting study is for a completely different type of facility but is useful in this evaluation to understand "Must" criteria and because of the utility of data collected during NPR site characterization. Some of the "Must" and "Want" criteria from this study will not be applicable to siting a remote-handled LLW disposal facility; however, they were included in the screening process presented in Appendix B.

\section{A-4.3 Idaho Mixed and Low-Level Waste Disposal Facility}

The Idaho Waste Processing Facility (IWPF), the Mixed and Low-Level Waste (MLLW) Treatment Facility, and the MLLW Disposal Facility were treatment, storage, and disposal facilities proposed at INL in the spring of 1992. The IWPF would be designed to treat stored and newly-generated inventories of mixed transuranic and alpha-contaminated mixed LLW. The MLLW Treatment Facility would treat mixed and low-level waste streams generated by ongoing activities, and possibly wastes generated by decommissioning and decontamination, and remediation activities within the DOE complex. The MLLW Disposal Facility would be a disposal site for treated mixed, low-level, and low-level alpha-contaminated wastes.

A preliminary siting activities study (Taylor et al. 1994) for these facilities describes the first steps in the site selection process as follows: (1) develop site selection criteria which are generally applicable to both treatment and disposal facilities, (2) select suitable candidate locations to consider in light of the selection criteria, and (3) obtain characterization data specific to the identified candidate locations that could be used to make an objective comparison of these locations to identify and select a suitable site for the new facility (or facilities).

Site selection criteria were developed through review of existing federal and state statutes and relevant DOE orders. An INL management advisory committee used the results of the review as a starting point for identification of criteria that encompassed waste transportation, environmental impacts, public/worker health and safety, archaeological resources, geology/seismology, and service/support requirements. The "Must" criteria that ultimately were used in the selection of candidate areas for a collocated IWPF/MLLW Facility included:

- The facility must be above the 100 -year flood elevation

- The facility must not be located on any site listed in the Federal Facilities Agreement and Consent Order (DOE-ID 1991), with the exception of Waste Area Group (WAG) 10 (i.e., Snake River Plain Aquifer)

- $\quad$ The facility must not be located on any known wetland 
- $\quad$ The facility must not be located within $1 \mathrm{mi}$ of a Category I facility

- The facility should not be located within $200 \mathrm{ft}$ of a capable fault.

Eight candidate locations ( 3 to $8 \mathrm{mi}^{2}$ each) were selected by a field committee comprised of technical personnel who identified preferred and non-preferred areas of INL from the standpoint of each siting criterion. The field committee conducted site walkovers at each area to inspect and evaluate the site against specific siting criteria (e.g., presence of archaeological artifacts, presence of wetlands or critical habitat, evidence of geologic/seismic hazards, soil depth and types, evidence of past flooding, etc.). Following a review of the site walkover observations, the advisory committee chose three sites from the original eight candidate areas. Selection of these three sites was based on the relative advantages and disadvantages of each of the eight areas, compiled from the site walkovers. After the selection was made, three additional sites were added for consideration based partly on previous siting work and partly on the premise that development and operational costs could be minimized if the facilities were located close to the RWMC.

This siting study did not assign weighting factors to the criteria and consequently did not complete a ranking of candidate sites. However, the study is useful for identifying criteria that were used to evaluate candidate sites for location of a LLW facility. The full complement of "Want" criteria derived from the IWPF/MLLW study are presented and screened for use in Appendix B.

\section{A-4.4 Idaho CERCLA Disposal Facility}

The ICDF is an engineered disposal facility, consisting of disposal cells and other support structures. The 80 -acre facility is designed to contain up to six cells with a total capacity of approximately $510,000 \mathrm{yd}^{3}$ of waste. The ICDF began operations in 2003 and is the selected remedy for disposal of contaminated surface soils from WAG 3, as well as CERCLA soils and debris from other WAGs. This waste will be permanently contained in the ICDF for long-term protection of human health and the environment.

Site selection for the ICDF was documented in the Operable Unit 3-13 Record of Decision (ROD) (DOE-ID 1999). As stated in the ROD, the best location to site the ICDF was evaluated using the analytical hierarchy process decision analysis technique. The analysis considered five "Must" criteria and 16 "Want" criteria. Based on this evaluation, it was determined that locating the facility within the area of concern was the most cost effective and applicable or relevant and appropriate requirement-compliant location for siting the ICDF. The Agencies (i.e., DOE, EPA, and Idaho Department of Health and Welfare) determined the study area for siting the ICDF to be the CPP-67 Percolation Ponds and adjacent areas to the west based on preliminary geotechnical information. However, the specific ICDF cell locations were determined through completion of a comprehensive geotechnical evaluation of the entire Study Area, which was reviewed and approved by the Agencies (DOE-ID 2000). The "Must" siting criteria for location of the ICDF included:

- $\quad$ Outside the 100-year floodplain

- $\quad$ Outside of wetland areas

- $\quad$ Not in active seismic zones

- Not in high surface erosion areas

- Not in an area of high historic groundwater table. 
The ICDF study was more limited than the other studies considered because it was focused on disposal of material from a specific WAG, resulting in the need to collocate to the extent practicable while meeting the "Must" criteria. This necessarily limited the candidate site locations to an area in the vicinity of INTEC. The evaluation is valuable because it provides additional insight into an area that was considered by all the other studies. In particular, the detailed geotechnical data will be of significant value to other candidate sites located nearby. The "Must" and "Want" criteria from this study are included in the screening presented in Appendix B.

\section{A-4.5 Compilation of Previous Siting Study Criteria}

The four existing studies were reviewed because they have already identified criteria and locations at INL that are appropriate for siting nuclear facilities, including low-level waste disposal facilities, waste treatment facilities, and nuclear reactors. This breadth of siting studies ensures that a full complement of criteria is considered for siting a remote-handled LLW disposal facility. In addition to the previous siting studies, regulations and DOE Orders were reviewed to identify criteria that may have been considered in previous studies but was not documented in the final report. Appendix B captures the full breadth of criteria from the four studies.

Strategies used for site ranking varied in the different studies. In one instance it was designed with such a wide range of weighting factors (WF) and scores (WF 1 to 10 , Score 1 to 10) that important criteria cancelled other important criteria and scores tended to a median value, limiting the usefulness of a numerical rank. In another instance the process focused only on scoring individual criteria and did not identify a weighting factor so the best candidate sites were not identified. The remaining two studies used professional judgment to assign weighting factors and scores. In spite of the variability in evaluation ranking strategy, the previous studies provided insight on how a simplified approach could be developed and implemented. Section 2.2 of this Siting Evaluation Report presents the simplified scoring and ranking approach developed from review of the previous four studies.

The number of siting evaluation criteria derived from the above studies is extensive and there are many occurrences of duplicate or similarly worded criteria used in the four studies. Managing the large number of criteria in a clear manner that leads to an easily understood outcome is quite a challenge. The solution to this challenge is to compile and screen all the evaluation criteria in one location of the report, Appendix B, and carry forward into the body of this Siting Study Report only those criteria that pass the screening and will be used in the final evaluation and ranking. The major advantage derived from the previous studies is compilation of an extensive list of evaluation criteria. Integration of all four studies with additional independently identified criteria has resulted in 53 potential criteria where each of the previous studies individually only considered from 21 to 50 criteria. The approach to developing criteria for this evaluation also included criteria that were found in regulations or guidance but not explicitly addressed by the previous studies. Appendix B screens the 53 potential criteria and Section 3.1 of this Siting Study Report presents the selected "Must" and "Want" criteria.

Another benefit of the previous studies is identification of site locations across INL. In some cases, the previous studies evaluated "areas" and in some cases "sites." "Areas" were most often one or more square mile sections and "sites" were only shown as a small dot on large-scale maps (1-in. = approximately $8 \mathrm{mi}$ ). None of the previous studies gave specific coordinates for sites and as a result only general locations could be derived for this evaluation. However, sufficient information is available to screen 34 sites or areas as possible locations for a remote-handled LLW disposal facility. Section 3.2 of this Siting Study Report summarizes the 34 sites and provides a figure to identify their location within INL. 


\section{A-5. REFERENCES}

10 CFR 61, 2002, Title 10, "Energy," Part 61, "Licensing Requirements for Land Disposal of Radioactive Waste," Code of Federal Regulations, Office of the Federal Register.

10 CFR 61, 2002, Title 10, "Energy," Part 61, "Licensing Requirements for Land Disposal of Radioactive Waste," Subpart C, "Performance Objectives (Parts 40 through 44)," Code of Federal Regulations, Office of the Federal Register.

10 CFR 61.50, 2002, Title 10, "Energy," Part 61, "Licensing Requirements for Land Disposal of Radioactive Waste," Section 61.50, "Disposal Site Suitability Requirements for Land Disposal," Code of Federal Regulations, Office of the Federal Register.

10 CFR 830, 2002, Title 10, "Energy," Part 830, "Nuclear Safety Management," Code of Federal Regulations, Office of the Federal Register.

10 CFR 1022, 2002, Title 10, "Energy," Part 1022, "Compliance with Floodplain and Wetland Environmental Review Requirements," Code of Federal Regulations, Office of the Federal Register.

33 CFR 323, 2002, Title 33, "Navigation and Navigable Waters," Part 323, "Permits for Discharges of Dredged or Fill Material into Waters of the United States," Code of Federal Regulations, Office of the Federal Register.

33 CFR 328.3, 2002, Title 33, "Navigation and Navigable Waters," Part 328, "Definition of Waters of the United States," Section 328.3, "Definitions," Code of Federal Regulations, Office of the Federal Register.

40 CFR 61, 2002, Title 40, "Protection of Environment," Part 61, "National Emission Standards for Hazardous Air Pollutants," Code of Federal Regulations, Office of the Federal Register.

40 CFR 230.3, 2001, Title 40, "Protection of Environment," Part 230, "Section 404(b)(1) Guidelines for Specifications of Disposal Sites for Dredged or Fill Material," Section 230.3, "Definitions," Code of Federal Regulations, Office of the Federal Register.

40 CFR 231, 2001, Title 40, "Protection of Environment," Part 231, "Section 404(c) Procedures," Code of Federal Regulations, Office of the Federal Register.

16 U.S.C. 1B, 470aa et seq., "Archaeological Resources Protection Act of 1979," as amended, United States Code.

16 U.S.C. 431 et seq., “American Antiquities Act of 1906,” United States Code.

16 U.S.C. 469-469c, “Archaeological and Historic Preservation Act of 1974," as amended, United States Code.

16 U.S.C. 470 et seq., "National Historic Preservation Act of 1966," as amended through 2000 [with annotations], United States Code.

16 U.S.C. 1531 to 1534, "Endangered Species Act of 1973," as amended, United States Code. 
25 U.S.C. 32, 3001 et seq., "Native American Graves Protection and Repatriation Act of 1990," United States Code.

42 U.S.C. 21, 1996, "American Indian Religious Freedom Act (Protection and Preservation of Traditional Religions of Native Americans)," United States Code.

ANSI/ANS-2.26-2004, "Categorization of Nuclear Facility Structures, Systems, and Components for Seismic Design," American Nuclear Society, 2004.

ASCE/SEI 43-05, "Seismic Design Criteria for Structures, Systems and Components in Nuclear Facilities," American Society of Civil Engineers, 2003.

DOE Guide 420.1-1, Nonreactor Nuclear Safety Design Criteria and Explosives Safety Criteria Guide for use with DOE O 420.1, Facility Safety, U.S. Department of Energy, March 28, 2000.

DOE Guide 420.1-2, Guide for the Mitigation of Natural Phenomena Hazards for DOE Nuclear Facilities and Nonnuclear Facilities, U.S. Department of Energy, March 28, 2000.

DOE Guide 421.1-2, Implementation Guide for Use in Developing Documented Safety Analyses to Meet Subpart B of 10 CFR 830, U.S. Department of Energy, October 24, 2001.

DOE Guide 435.1-1, Implementation Guide for use with DOE M 435.1-1, U.S. Department of Energy, July $9,1999$.

DOE Manual 435.1-1, Radioactive Waste Management Manual, U.S. Department of Energy, June 19, 2001.

DOE Order 413.3B, Change 1, Program and Project Management for the Acquisition of Capital Assets, July $28,2006$.

DOE Order 420.1B, Facility Safety, U.S. Department of Energy, December 22, 2005.

DOE Order 430.1B, Real Property Asset Management, U.S. Department of Energy, September 24, 2003.

DOE Order 435.1, Radioactive Waste Management, U.S. Department of Energy, August 28, 2001.

DOE Order 450.1, Environmental Protection Program, U.S. Department of Energy, January 15, 2005.

DOE Policy 141.1, Department of Energy Management of Cultural Resources, U.S. Department of Energy, May 2, 2001.

DOE-ID, 1991, Federal Facility Agreement and Consent Order for the Idaho National Engineering Laboratory, U.S. Department of Energy, Idaho Field Office; U.S. Environmental Protection Agency, Region 10; Idaho Department of Health and Welfare, 1088-06-29-120, December 1991.

DOE-ID, 1999. Final Record of Decision Idaho Nuclear Technology and Engineering Center, Operable Unit 3-13. DOE/ID-10660, Revision 0. U.S. Department of Energy Idaho Operations Office, Idaho Falls, Idaho.

DOE-ID, 2000, Geotechnical Report for the Conceptual Design of the INEEL CERCLA Disposal Facility at Waste Area Group 3, Operable Unit 3-13, DOE/ID-10812, Revision 0. U.S. Department of Energy Idaho Operations Office, Idaho Falls, Idaho. 
DOE-STD-1020-2002, Natural Phenomena Hazards Design and Evaluation Criteria for Department of Energy Facilities, U.S. Department of Energy, January 2002.

DOE-STD-1021-93, Natural Phenomena Hazards Performance Categorization Guidelines for Structures, Systems, and Components, U.S. Department of Energy, April 2002.

DOE-STD-1027-92, Hazard Categorization and Accident Analysis Techniques for Compliance with DOE Order 5820.23, Nuclear Safety Analysis Reports, Change 1, September 1997.

DOE-STD-1189-2008, Integration of Safety into the Design Process, U.S. Department of Energy, March 2008.

DOE-STD-3009-94, Preparation Guide for U.S. Department of Energy Nonreactor Nuclear Facility Documented Safety Analysis, U.S. Department of Energy, March 2006.

EPA, 2007, Section 404 of the Clean Water Act: How Wetlands are Defined and Identified, Accessed on the internet July 24, 2007 at http://www.epa.gov/owow/wetlands/facts/fact11.html, U.S. Environmental Protection Agency.

Executive Order 11988, "Floodplain Management Guidelines," 42 Federal Register (FR) 26951, May 24, 1977, Washington, D.C.

Executive Order 11990, "Protection of Wetlands," 42 Federal Register (FR) 26961, May 24, 1977, Washington, D.C.

Executive Order 13007, "Indian Sacred Sites," 61 Federal Register (FR) 104, May 24, 1996, Washington, D.C.

Executive Order 13175, "Consultation and Coordination with Indian Tribal Governments," 65 Federal Register (FR) 218, November 6, 2000, Washington, D.C.

Holdren, K.J., J.D. Burgess, K.N. Keck, D.L. Lowrey, M.J. Rohe, R.P. Smith, C.S. Staley, and J. Banaee, 1997, Preliminary Evaluation of Potential Locations on the Idaho National Engineering and Environmental Laboratory for a High-Level Waste Treatment and Interim Storage Facility and a Low-Level Waste Landfill, INEEL/EXT-97-01324, Revision 0, Lockheed Martin, Idaho Falls, Idaho.

IDAPA 58.01.01, "Rules for the Control of Air Pollution in Idaho," Idaho Administrative Procedures Act, Idaho Department of Environmental Quality (Current as of July 1, 2007).

IDAPA 58.01.06, "Solid Waste Management Rules and Standards," Idaho Administrative Procedures Act, Idaho Department of Environmental Quality (Current as of July 1, 2007).

INL, 2008, INL Safety Analysis Process, Nuclear Safety, NS-18101, Revision 3, Idaho National Laboratory, May 6, 2008.

Kostelnik, K.M., 2005, Idaho National Laboratory Comprehensive Land Use and Environmental Stewardship Report, INL/EXT-05-00726. Idaho National Laboratory, Idaho Falls, Idaho.

NRC, 2000, A Performance Assessment Methodology for Low-Level Radioactive Waste Disposal Facilities, Recommendations of NRC's Performance Assessment Working Group, NUREG 1573, 
Performance Assessment Working Group, Division of Waste Management, Office of Nuclear Material Safety and Safeguards, U.S. Nuclear Regulatory Commission, October 2000.

NRC, 2007, History and Framework of Commercial Low-Level Radioactive Waste Management in the United States, NUREG 1853, Advisory Committee on Nuclear Waste White Paper prepared by M.T. Ryan, M.P. Lee, and H.J. Larson, Advisory Committee on Nuclear Waste, U.S. Nuclear Regulatory Commission, Washington, DC 20555-0001.

Ostenaa, D.A., and D.R.H. O'Connell, 2005, Big Lost River Flood Hazard Study Idaho National Laboratory, Idaho, Report 2005-2, U.S. Department of the Interior Bureau of Reclamation, Denver, Colorado.

PL 91-604, Clean Air Act of 1990, Public Law.

Pomeroy, P.W., B.J. Garrick, W.J. Hinze, G.M. Hornberger, and J.T. Larkins, "Time of Compliance for Low-Level Nuclear Waste Disposal Facilities," February 11, 1997, in: A Compilation of Reports of The Advisory Committee on Nuclear Waste, July 1996 - June 1997, U.S. Nuclear Regulatory Commission, August 1997.

Spry, M.J., K.S. Moor, S.J. Maheras, and H.K. Peterson, 1989, Site Selection Report for the New Production Reactor at the Idaho National Engineering Laboratory, EGG-NPR-8517, Revision 1, EG\&G Idaho, Inc., Idaho Falls, Idaho.

Taylor, D.D., R.L. Hoskinson, C.O. Kingsford, and L.W. Ball, 1994, Preliminary Siting Activities for New Waste Handling Facilities at the Idaho National Engineering Laboratory, EGG-WM-11118, EG\&G Idaho, Inc., Idaho Falls, Idaho.

TFR-483, "Draft Technical and Functional Requirements Remote-Handled Low-Level Waste Disposal Facility," TFR-483, Draft Revision E, July 24, 2007, Idaho National Laboratory, Idaho Falls, Idaho. 


\section{Appendix B}

\section{Identification of Site Evaluation Criteria}


B-2 


\section{CONTENTS}

ACRONYMS B-6

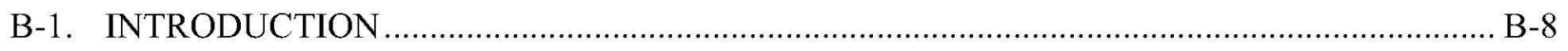

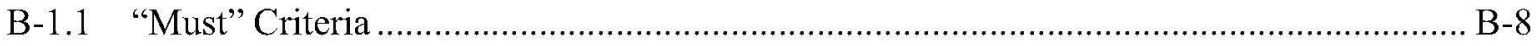

B-1.2 "Want” Criteria Based on Facility Performance ....................................................... B-10

B-2. "MUST" CRITERIA SCREENING AND SELECTION ........................................................ B-10

B-2.1 Selected "Must" Criteria................................................................................................... B-11

B-2.1.1 [1] Must Not be Located within 5 Miles of a Capable Fault........................ B-12

B-2.1.2 [2] Must Not be Located in the 500-year Floodplain .................................. B-12

B-2.1.3 [3] Must Not be Located in an Area of Less than 5 Acres ........................... B-12

B-2.1.4 [4] Must Not be Located in a Wetland ................................................... B-13

B-2.2 "Must” Criteria Moved to "Want" Category ……............................................................ B-13

B-2.2.1 [5] Minimize Impact from Earthquakes .............................................. B-13

B-2.2.2 [6] Maximize Distance from Volcanic Hazard Zones................................. B-13

B-2.2.3 [7] Capable of Being Characterized ......................................................... B-14

B-2.2.4 [8] Avoid Areas of Surface Water Flooding/Ponding .................................. B-14

B-2.2.5 [9] Locate Within Core Infrastructure Area ............................................... B-15

B-2.2.6 [10] Locate Near Utilities and Transportation ....................................... B-15

B-2.2.7 [11] Avoid Critical Habitats of Endangered Species .................................... B-15

B-2.3 "Must” Criteria Considered but Not Used..................................................................... B-16

B-2.3.1 [12] Must be Located 1 Mile or More from Category 1 Facility .................. B-16

B-2.3.2 [13] Avoid Maximum Mackay Dam Failure Flood Elevation ........................ B-16

B-2.3.3 [14] Avoid High Surface Erosion Areas .................................................... B-17

B-2.3.4 [15] Avoid Groundwater Discharge Areas............................................. B-17

B-2.3.5 [16] Avoid Groundwater Intrusion .......................................................... B-17

B-2.3.6 [17] Consider Population Density Limits................................................ B-18

B-2.4 Recommended "Must" Criteria ............................................................................... B-18

B-3. "WANT" CRITERIA SCREENING AND SELECTION ........................................................ B-18

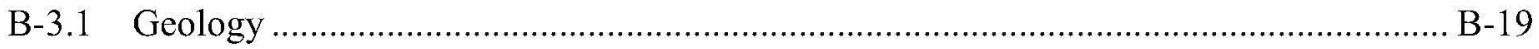

B-3.1.1 [18] Maximize Surficial Sediment Thickness .......................................... B-20

B-3.1.2 [19] Maximize Sediment Thickness Continuity ............................................ B-20

B-3.1.3 [20] Enhance Retardation to Minimize Migration ................................. B-21

B-3.1.4 [21] Maximize Interbed Continuity ........................................................ B-22

B-3.1.5 [22] Minimize Impact from Earthquakes ............................................ B-22

B-3.1.6 [23] Maximize Distance from Volcanic Hazard Zones................................ B-23

B-3.1.7 [24] Locate to Facilitate Discriminatory Monitoring .................................. B-23 
B-3.1.8 [25] Availability of Geotechnical Data .................................................. B-24

B-3.1.9 [26] Availability of Characterization Data ................................................. B-24

B-3.1.10 [27] Avoid Areas of Known or Probable Subsidence ................................ B-24

B-3.1.11 [28] Minimize Cost of New Excavation .................................................. B-24

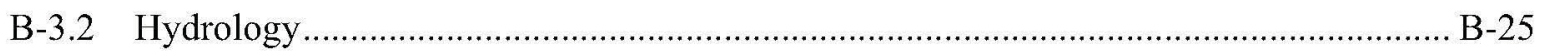

B-3.2.1 [29] Minimize Proximity to Floodplains.................................................. B-25

B-3.2.2 [30] Avoid Aquifer Recharge Areas ..................................................... B-26

B-3.2.3 [31] Avoid Areas of Surface Water Flooding/Ponding .............................. B-28

B-3.2.4 [32] Avoid Perched Water................................................................ B-28

B-3.2.5 [33] Avoid Wellhead Protection Areas .................................................... B-29

B-3.2.6 [34] Maximize Ground Water Transmissivity ............................................ B-29

B-3.2.7 [35] Minimize Depth of Wells for Water Supply...................................... B-29

B-3.2.8 [36] Not Directly Above Aquifer .............................................................. B-29

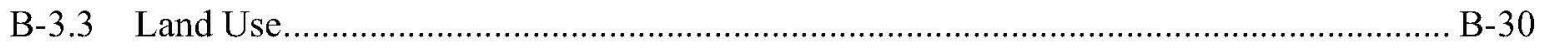

B-3.3.1 [37] Locate Within Core Infrastructure Area ........................................... B-31

B-3.3.2 [38] Avoid the Explosives Test Area ................................................... B-32

B-3.3.3 [39] Locate Near Utilities and Transportation ...................................... B-32

B-3.3.4 [40] Avoid Industrial and Controlled Areas ............................................. B-32

B-3.3.5 [41] Avoid Unexploded Ordnance Areas ................................................ B-33

B-3.3.6 [42] Minimize Adverse Interactions with Existing Facilities ....................... B-33

B-3.3.7 [43] Maximize Distance from Public Highways ....................................... B-33

B-3.3.8 [44] Maximize Distance from Site Boundaries .......................................... B-33

B-3.3.9 [45] Avoid Location South of US Highway 20/26................................... B-33

B-3.3.10 [46] Minimize Distance from Waste Generator to Facility ........................... B-34

B-3.4 Natural Resource Management ............................................................................. B-34

B-3.4.1 [47] Avoid the Sagebrush-Steppe Ecosystem Reserve ............................... B-35

B-3.4.2 [48] Avoid Vegetation Transects ........................................................ B-35

B-3.4.3 [49] Avoid Ecologically Sensitive Habitat............................................... B-35

B-3.4.4 [50] Use Previously Disturbed Areas..................................................... B-35

B-3.4.5 [51] Minimize Impacts to Cultural Resources …….................................... B-36

B-3.4.6 [52] Outside Wind Corridors of Existing INL Facilities............................. B-36

B-3.4.7 [53] Minimize Public Air Pollution Impact …….................................. B-36

B-3.5 Recommended "Want" Criteria ................................................................................. B-36

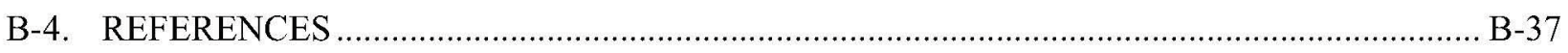




\section{FIGURES}

B-1. The overall process for siting, planning, and constructing a Remote-Handled

Low-Level Waste Disposal Facility.

B-2. Comparison of the estimated 500-, 1,000-, and 10,000-year floods

B-27

\section{TABLES}

B-1. Comparison of "Must" criteria considered by previous Idaho National Laboratory siting studies with those identified for use in this remote-handled LLW disposal facility siting study

B-2. Comparison of geology subject area "Want" criteria considered by previous INL siting studies with those identified for use in this siting study

B-3. Comparison of hydrology subject area "Want" criteria considered by previous INL siting studies with those identified for use in this siting study.

B-4. Comparison of land use subject area "Want" criteria considered by previous INL siting studies with those identified for use in this siting study.

B-5. Comparison of natural resource subject area "Want" criteria considered by previous INL siting studies with those identified for use in this siting study. 


\section{ACRONYMS}

\begin{tabular}{|c|c|}
\hline BLM & Bureau of Land Management \\
\hline bls & below land surface \\
\hline $\mathrm{CD}$ & Critical Decision \\
\hline CERCLA & Comprehensive Environmental Response, Compensation, and Liability Act \\
\hline CFR & Code of Federal Regulations \\
\hline DOE & Department of Energy \\
\hline DOE-ID & U.S. Department of Energy, Idaho Operations Office \\
\hline ECA & Environmentally Controlled Area \\
\hline EPA & U.S. Environmental Protection Agency \\
\hline ESA & Endangered Species Act \\
\hline ESER & Environmental Surveillance, Education, and Research \\
\hline $\mathrm{FFA} / \mathrm{CO}$ & Federal Facility Agreement/Consent Order \\
\hline FWS & U.S. Fish and Wildlife Service \\
\hline$\% g$ & percentage of gravitational acceleration \\
\hline gpm & gallons per minute \\
\hline ICDF & Idaho CERCLA Disposal Facility \\
\hline INL & Idaho National Laboratory \\
\hline INTEC & Idaho Nuclear Technology and Engineering Center \\
\hline IWPF & Idaho Waste Processing Facility \\
\hline LLW & low-level waste \\
\hline NEPA & National Environmental Policy Act \\
\hline NPR & New Production Reactor \\
\hline NRC & Nuclear Regulatory Commission \\
\hline $\mathrm{PC}$ & performance category \\
\hline PMF & Probable Maximum Flood \\
\hline
\end{tabular}




$\begin{array}{ll}\text { ROD } & \text { Record of Decision } \\ \text { RWMC } & \text { Radioactive Waste Management Complex } \\ \text { SRPA } & \text { Snake River Plain Aquifer } \\ \text { T\&E } & \text { threatened and endangered } \\ \text { T\&FR } & \text { technical and functional requirements } \\ \text { USGS } & \text { U.S. Geological Survey } \\ \text { UXO } & \text { unexploded ordnance } \\ \text { WAG } & \text { Waste Area Group }\end{array}$




\section{Appendix B \\ Identification of Site Evaluation Criteria}

\section{B-1. INTRODUCTION}

Site evaluation criteria are derived from Department of Energy (DOE) orders, federal and state laws and regulations, and facility-specific design and performance requirements. A site evaluation considers the facility performance category, waste form and volume, disposal container size and geometry, land use requirements, health and safety impacts, natural and cultural resource impacts, and a variety of detailed geologic and hydrologic characteristics. Organization of all this information into a coherent screening process is the objective of this appendix. This appendix is focused on identification of site evaluation criteria. Application of criteria to identify candidate locations for the Remote-Handled Low-Level Waste (LLW) Disposal Project facility is presented in Section 3 of the Siting Study Report and the detailed determination of site-by-site, criterion-by-criterion scores is summarized in Appendix C.

Appendix A provides a summary of the DOE orders, federal and state laws and regulations, facility specific objectives, and a summary of four previous siting studies conducted at the Idaho National Laboratory (INL). This information identifies requirements, many of which are applicable to evaluating candidate sites for location of an onsite remote-handled LLW disposal facility. The previous siting studies provide examples of the application of requirements to siting a number of different types of nuclear facilities. Each study used a common language to categorize criteria: a "Must" category to capture criteria that were determined to be most significant to facility siting, and "Want" criteria to evaluate desirable or undesirable site characteristics. This Remote-Handled LLW Disposal Project facility siting study continues this traditional usage within the framework of DOE Orders 435.1, Radioactive Waste Management and 420.1B, Facility Safety.

Throughout the siting evaluation process, it is important to remember where in the overall Critical Decision (CD) process the siting study actually resides. A Mission Need Statement, CD-0, has been approved for the project. An alternatives analysis has been prepared to assess onsite and offsite alternatives for meeting this mission need and recommend an alternative to be carried forward in the conceptual design for approval at CD-1. The siting study supports the need for identification of suitable locations for planning and further evaluating the onsite alternative. Figure B-1 provides an overview of the $\mathrm{CD}$ process in the context of the five $\mathrm{CD}$ phases (CD-0,1,2,3, and 4) and identifies the main activities performed in each phase. The siting study is conducted in parallel with the conceptual design. The technical requirements for a facility are based upon the technical and functional requirements (T\&FR; T\&FR-483) and Conceptual Design Report developed in support of CD-1. The site evaluation results in recommendation of locations at INL to be considered for selection as part of the National Environmental Policy Act (NEPA) process.

\section{B-1.1 "Must" Criteria}

A review of applicable regulations (see Appendix A) and "Must" criteria used in existing siting studies was conducted to develop a comprehensive "Must" criterion list. In general, the "Must" criteria are based on requirements found in regulations or DOE orders, or in a few instances on specific requirements of the facility in question. Previous studies have limited the number of "Must" criteria to those areas that are considered most important. If the candidate site did not meet all "Must" criteria, it was dropped as a potential site and not considered further. 


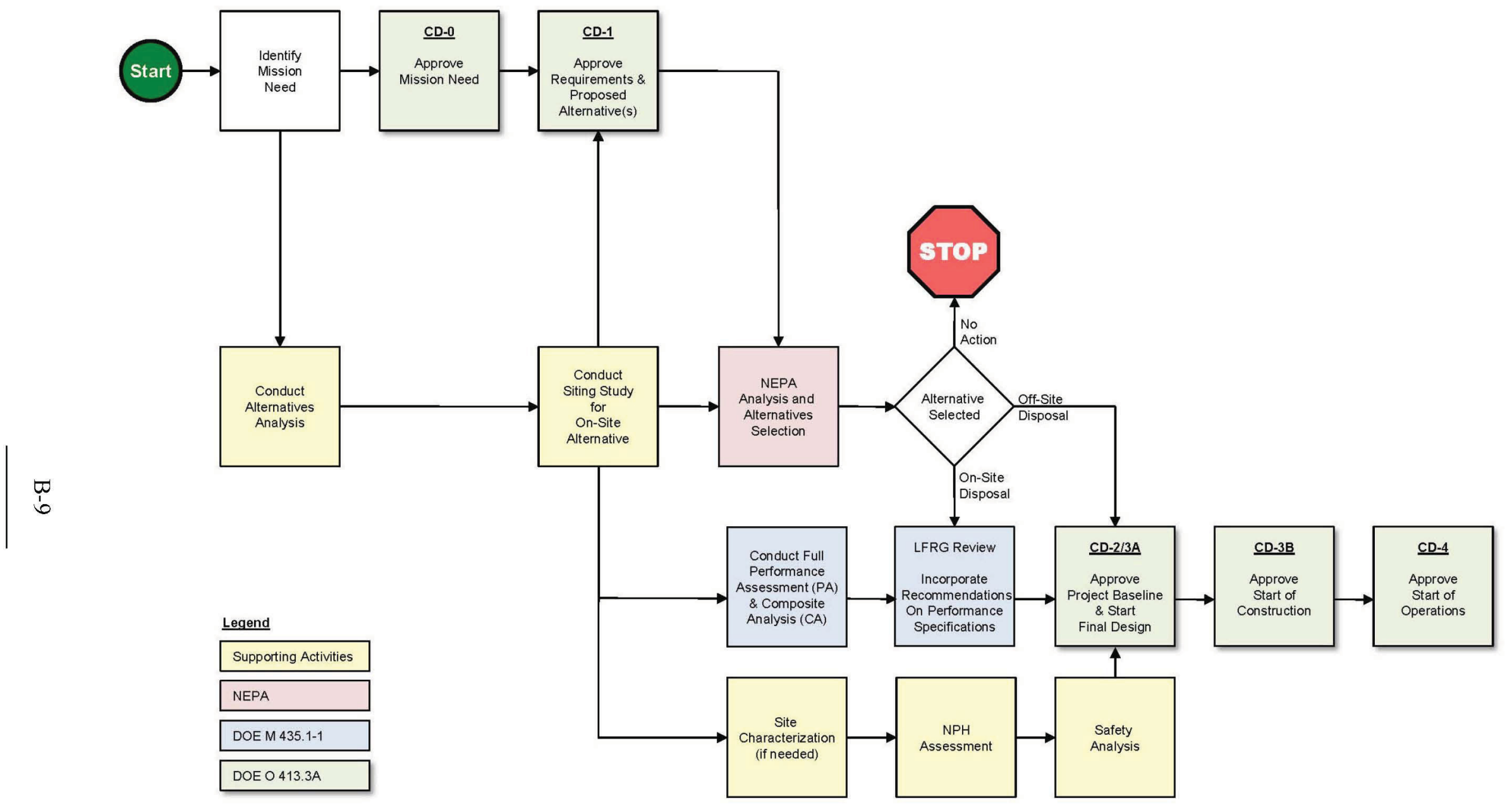

Figure B-1. The overall process for siting, planning, and constructing a Remote-Handled Low-Level Waste Disposal Facility. 
Review of the previous studies identified 17 "Must" criteria and three additional criteria were added based on review of the requirements found in DOE orders and regulations for a total of 20 criteria. After elimination of three duplicates, the total number of "Must" criteria considered for this siting evaluation is 17 . Section B-2 presents each criterion with a discussion of its application and a determination of whether or not it is appropriate for the onsite remote-handled LLW disposal facility site evaluation process. The screening process results in identification of four criteria to be included in the "Must" category, seven criteria that should be moved to the "Want" category for further consideration, and six criteria that have no applicability to siting a remote-handled LLW disposal facility at INL. Recommended "Must" criteria are identified at the end of the section and are carried forward to Section 3 of the Siting Study Report for screening of the candidate sites.

\section{B-1.2 "Want" Criteria Based on Facility Performance}

The list of "Want" criteria was developed using the seven carried over for further consideration from the "Must" criteria screening process, from regulations or DOE orders, and from previous siting studies. A total of 42 separate "Want" criteria were identified. Following review of the criteria, it became apparent that organization by subject area would facilitate the screening process significantly. Consequently, Section B-3 summarizes and screens criteria in the following groups:

- Geology

- Hydrology

- $\quad$ Land Use

- $\quad$ Natural Resources.

Screening "Want" criteria by subject area allows side-by-side comparison of criteria that address similar data types. This contributes to application of the scoring system in a more uniform fashion. Elimination of duplicate criteria resulted in a total of 36 "Want" criteria. Twenty-one of the 36 are identified for inclusion as "Want" criteria for siting the Remote-Handled LLW Disposal Facility. The remaining 15 were considered but not used. A summary of individual "Want" criteria screening is presented in Section B-3.

After elimination of duplicates, there are a total of 53 criteria ("Must" and "Want") identified for consideration in the Remote-Handled LLW Disposal Facility siting evaluation. All criteria are numbered consecutively in this Appendix. Thus, the "Must" criteria are numbered 1 through 17 and the "Want" criteria are numbered 18 through 53, resulting in a unique numerical identifier for each criterion. The numerical identifier is used as a crosswalk between the main report and all the appendices.

\section{B-2. “MUST” CRITERIA SCREENING AND SELECTION}

The 17 "Must" criteria presented in Table B-1 represent a synthesis of all identified "Must" criteria Section B-1.1) for selecting those pertinent and applicable to siting an onsite remote-handled LLW disposal facility. The table identifies the 17 criteria by number and indicates the result of the screening process. As shown by symbols in the far right-hand column, four criteria are identified as significant enough to be included in the "Must" evaluation $(\checkmark)$, seven are identified for further consideration as "Want" criteria $(+)$, and six are considered but not used $(\bullet)$. Criteria in the 'considered but not used' category are either not appropriate for screening sites in this study, or were included in other criteria. The screening of each criterion is summarized in Sections B-2.1, B-2.2, and B-2.3. 
Table B-1. Comparison of "Must" criteria considered by previous Idaho National Laboratory siting studies with those identified for use in this remote-handled LLW disposal facility siting study.

\begin{tabular}{|c|c|c|}
\hline $\begin{array}{l}\text { "Must" Criteria Identified from } \\
\text { Previous Siting Evaluations }\end{array}$ & $\begin{array}{l}\text { "Must" Criteria Considered for onsite Remote- } \\
\text { Handled LLW Disposal Facility Evaluation }\end{array}$ & \\
\hline $5 \mathrm{mi}$ from capable faults & 1. Must not be located within $5 \mathrm{mi}$ of a capable fault & $\checkmark$ \\
\hline Minimum of $200 \mathrm{ft}$ from a capable fault & Captured in \#1 & \\
\hline Outside, above, or avoid the 100 -year floodplain & 2. Must not be located in the 500 -year floodplain & $\checkmark$ \\
\hline $1 \mathrm{mi}^{2}$ or more area & 3. Must not be located in an area of less than 5 acres & $\checkmark$ \\
\hline Avoid or outside wetland & 4. Must not be located in a wetland & $\checkmark$ \\
\hline Not in active seismic zones & 5. Minimize impact from earthquakes & + \\
\hline Outside volcanic areas & 6. Maximize distance from volcanic hazard zones & + \\
\hline $\begin{array}{l}\text { Avoid areas where tectonic processes such as } \\
\text { faulting, folding, seismic activity, or volcanism may } \\
\text { occur }\end{array}$ & Captured in $\# 5$ and $\# 6$ & \\
\hline Not considered previously & 7. Capable of being characterized & + \\
\hline Not considered previously & 8. Avoid areas of surface water flooding or ponding & + \\
\hline $\begin{array}{l}\text { Excludes Federal Facility Agreement/Consent } \\
\text { Order (FFA/CO) sites, Environmentally Controlled } \\
\text { Areas (ECAs) }\end{array}$ & 9. Location within core infrastructure area & + \\
\hline $30,050 \mathrm{ac}-\mathrm{ft} / \mathrm{yr}(18,600 \mathrm{gpm})$ water availability & 10. Locate near transportation and utilities & + \\
\hline Avoid critical habitats of endangered species & 11. Avoid critical habitats of endangered species & + \\
\hline $\begin{array}{l}\text { No unique habitat; doesn't destroy endangered } \\
\text { species }\end{array}$ & Captured in \#11 & \\
\hline Minimum of $1 \mathrm{mi}$ to Category 1 facilities & 12. Avoid location within $1 \mathrm{mi}$ of Category 1 facility & - \\
\hline $\begin{array}{l}\text { Above maximum Mackay Dam failure flood } \\
\text { elevation }\end{array}$ & $\begin{array}{l}\text { 13. Avoid maximum Mackay Dam failure flood } \\
\text { elevation }\end{array}$ & - \\
\hline Not in high surface erosion areas & 14. Avoid high surface erosion areas & - \\
\hline Not considered previously & 15. Avoid groundwater discharge areas & - \\
\hline Not in an area of high historic groundwater table & 16. Avoid groundwater intrusion & - \\
\hline $\begin{array}{l}\text { Meet } 10 \text { Code of Federal Regulations (CFR) } 100 \\
\text { population density limits }\end{array}$ & 17. Consider population density limits & - \\
\hline $\begin{array}{l}\checkmark=\text { Criterion included in the "Must" category. } \\
+=\text { Criterion included in the "Want" category. } \\
\bullet=\text { Criterion considered but not used. }\end{array}$ & & \\
\hline
\end{tabular}

\section{B-2.1 Selected "Must" Criteria}

Four criteria are identified for inclusion in this Siting Study's "Must" evaluation. Review of each criterion is presented below to (1) establish its origin, and (2) to identify specific features of INL that contribute to selection of the criterion for use in the evaluation. 


\section{B-2.1.1 [1] Must Not be Located within 5 Miles of a Capable Fault}

This criterion is found in two of the four siting studies. Minimizing the risk from seismic events is an important consideration and is addressed by the natural phenomena hazards clauses in DOE Order 420.1, DOE Guide 420.1-1, and DOE Guide 420.1-2. The Nuclear Regulatory Commission (NRC) definition of a capable fault states in part that a fault is capable if there has been ground movement at or near the ground surface at least once in the past 35,000 years or movement of a recurring nature within the past 500,000 years. Based on this definition, the capable faults nearest to INL are the Howe section of the Lemhi fault, the Arco section of the Lost River fault (U.S. Geological Survey [USGS] 2006), and the Blue Dome segment of the Beaverhead fault (Crone and Haller 1991). These faults terminate just outside the western border of INL, but if a 5-mi scoring zone is considered, the zones for the Lemhi and Beaverhead faults would extend onto INL. Owing to the potential importance of minimizing risk from seismic events and the relative ease of avoiding sites near capable faults, this "Must" criterion is appropriate and the 5 -mi buffer is understood to be conservative.

\section{B-2.1.2 [2] Must Not be Located in the 500-year Floodplain}

A floodplain criterion is found in three of the four siting studies, siting of New Production Reactor (NPR) being the one exception. In all three cases, the Design Basis Flood was the 100-year flood. Avoidance of a floodplain or development of engineered controls is mandated by DOE Manual 435.1-1. Guidance from 10 CFR 61.50(5) (not a requirement for DOE facilities) is more strongly worded: "Waste disposal shall not take place in a 100-year floodplain." In addition, DOE Guide 420.1-2 states that "structures must not be located in floodplains." Combining the performance category determination for the remote-handled LLW disposal facility (PC-1) with requirements found in DOE-STD-1020-2002 indicates siting should consider a flood recurrence probability of $2 \times 10^{-3}$ or the 500 -year flood. The criterion of avoiding floodplains is part of an overarching objective of avoiding sites where the groundwater table (perched or regional) may rise to within $29 \mathrm{ft}$ of ground surface or where surface water ponding or flooding could inundate a disposal site within the post-closure performance assessment period. Consequently, the preferred location for the remote-handled LLW disposal facility would be outside the 500-year floodplain; however, the waste form and vault design would allow consideration of a location inside the 500-year floodplain with appropriate engineered controls. A conservative approach to the siting evaluation is to include location outside the 500-year floodplain as a "Must." A further evaluation of flooding is included in the "Want" category to allow scoring based on a site's proximity to the 1,000-year floodplain and the footprint of pluvial Lake Terreton (e.g., a 10,000-year flood).

\section{B-2.1.3 [3] Must Not be Located in an Area of Less than 5 Acres}

Two of the previous siting studies included a facility area requirement. In addition, DOE Manual 435.1 IV (M)(1)(a)(1) specifies that the facility must be "Located to accommodate the projected volume of waste." In terms of a facility siting requirement, the available area is the most significant factor in meeting the DOE requirement. Facility size is derived from the size and shape of waste containers and from the configuration of disposal container placement in vaults. It is anticipated that liners adequate for disposal of the remote-handled LLW wastes will be used.

Conceptual design of an onsite remote-handled LLW disposal facility allows the option for the new vault system to be configured to allow either two or three waste containers to be placed within each vertical vault. Combining waste container configuration with estimated waste stream volume and disposal vault configuration indicates that a conservative total area of at least 5 acres may be needed to accommodate an onsite remote-handled LLW disposal facility (see Appendix A for vault configuration details). The ability to provide the three-liner disposal configuration is dependent on the available depth of surface sediments present at the siting location. Consequently, it is recommended that the depth of 
surficial sediments be considered as a "Want" criterion, while facility area is considered a "Must" criterion set conservatively at 5 acres. Considering depth of surficial sediment thickness as a "Want" criterion supports design and operations flexibility.

\section{B-2.1.4 [4] Must Not be Located in a Wetland}

This criterion is found in two of the four studies. Executive Order 11990 mandates the protection of wetlands, guidelines for determining wetlands are provided in 10 CFR 1022.11, and wetlands are considered as siting criteria in 10 CFR 61.50(5). The criterion of avoiding wetlands is part of an overarching objective of avoiding sites where the groundwater table (perched or regional) may rise to within $29 \mathrm{ft}$ of ground surface (the anticipated depth of vault construction) or where surface water ponding or flooding could inundate a disposal site within the post-closure performance assessment period. The Remote-Handled LLW Disposal Project NEPA process must include a wetlands assessment (10 CFR 1022.12) as part of the formal site selection process for any action within a wetland or floodplain. The Army Corps of Engineers is responsible for delineation of wetlands and the National Wetlands Inventory identifies only one wetland at INL (in the vicinity of the Big Lost River Sinks). Given the high desert environment at INL, mitigation actions required to compensate for location of a facility in a wetland would be difficult, leaving relocation of the facility as the most suitable option. A formal field survey of proposed site will be conducted as part of the NEPA process to ascertain the presence of wetlands, and if present a formal delineation and consultation with the U.S. Army Corps of Engineers would occur to determine impacts and appropriate mitigation measures. In addition, the nature of the waste requires disposal in a dry environment (above the water table) in an area where groundwater intrusion is absent. Consequently, avoidance of wetlands is considered a "Must" criterion for the remote-handled LLW disposal siting evaluation.

\section{B-2.2 "Must" Criteria Moved to "Want" Category}

Seven criteria are identified for further consideration in this Siting Study's "Want" evaluation. Review of each criterion is presented below to (1) establish its origin, and (2) to identify specific features of INL that contribute to a recommendation to consider further in the "Want" evaluation.

\section{B-2.2.1 [5] Minimize Impact from Earthquakes}

An evaluation of seismic events was included in three of the previous siting studies. Both DOE Orders 435.1 and 420.1B (with manuals, guides, and sub-tier standards) identify seismic hazard as a necessary component of the siting evaluation process. The criterion is also found in NRC LLW facility siting guidance where the statement "areas must be avoided where tectonic processes such as faulting, folding, seismic activity, or volcanism may occur..." (10 CFR 61.50(9)) highlights the importance of understanding the tectonic nature of a candidate site. Although NRC guidance is not applicable to DOE facilities, it is clear through similarity of wording that the requirements of DOE Orders 435.1 and 420.1B for natural phenomena hazard assessment considered the intent of NRC guidance. A seismic impact criterion is designed to provide a relative measure of the potential for seismic-induced damage at each the candidate disposal facility sites. Regional seismic activity has been monitored at INL with a seismic monitoring network established in 1973. Evaluation of seismic response across INL is an appropriate evaluation criterion and is considered as "Want" Criterion \#22 (Section B-3.1.5).

\section{B-2.2.2 [6] Maximize Distance from Volcanic Hazard Zones}

This criterion was included in two of the previous siting studies. Both DOE Orders 435.1 and 420.1B (with sub-tier manuals, guides, and standards) recognize the hazards associated with volcanic 
activity. In addition, one NRC characterization objective (10 CFR 61.50(9) states that "areas must be avoided where tectonic processes such as faulting, folding, seismic activity, or volcanism may occur...".

The INL is located on the Snake River Plain in an area of recent volcanism. Volcanic hazards of the site have been characterized and the site has been divided into several volcanic hazard classes (Hackett, Smith, and Khericha 2002). The probability of a volcanic event is several orders of magnitude lower than the probability of a seismic event. Even though volcanic events have a low probability, it is recommended that a volcanic hazard criterion be included in the "Want" category ("Want" Criterion \#23, Section B-3.1.6).

\section{B-2.2.3 [7] Capable of Being Characterized}

A criterion specifically related to a candidate site's ability to be characterized is not included in any of the four site evaluation reports. However, DOE Manual 435.1 states that a site evaluation should "consider environmental characteristics," and 10 CFR 61.50(2) states that "the disposal site shall be capable of being characterized, modeled, analyzed, and monitored." Numerous activities over the operational history of INL have conducted in-depth characterization activities and that body of information is available to support this and future siting studies. Given the amount of characterization already completed at INL, it is reasonable to conclude that any location within the INL boundary can be characterized with existing data or through additional detailed characterization activities once a final preferred site is selected through the NEPA process. This criterion is quite important but because of the extent of existing characterization, it does not warrant consideration as a "Must." However, it will be considered a "Want" criterion to measure the degree to which a candidate site has existing characterization data. It is recommended that two aspects of "characterization" be considered: 1) availability of geotechnical data, and 2) availability of characterization data. Both have been considered as "Want" criteria ("Want" Criterion \#25, Section B-3.1.8 and "Want" Criterion \#26, Section B-3.1.9).

\section{B-2.2.4 [8] Avoid Areas of Surface Water Flooding/Ponding}

This criterion is found in one of the previous studies as well as in DOE Manual 435.1 and 10 CFR 61.50(5), which states that the disposal site must be "generally well drained and free of areas of flooding or frequent ponding...". Annual precipitation in the vicinity of INL ranges from 9 to 14 inches per year. A significant portion of INL surficial geology is comprised of undulating lava flows that provide localized depressions where ponding could occur. Both the Big Lost River and Birch Creek flow to playas on INL where there may be ponding of water if spring runoff flows are sufficiently high. Rainfall on local snowpack and subsequent rapid snowmelt, when coupled with low topographic relief, commonly result in local ponding and flooding that could compromise the performance of a LLW disposal facility. Sustained ponding and flooding can also result in conditions conducive to development of flow through the vadose zone. Generally speaking, a location with elevated topography and good surface-water drainage is required, while a location with subdued topography and poor surface-water drainage would be unacceptable, unless engineering controls were used to eliminate the potential for localized flooding or ponding. This criterion is part of an overarching objective of avoiding sites where the groundwater table (perched or regional) may rise to within $29 \mathrm{ft}$ of ground surface or where surface water ponding or flooding could inundate a disposal site within the post-closure performance assessment period. This criterion should be considered as a corollary to criterion \#4, "Must not be located in a wetland). Because disposal should occur in a dry environment, this is a criterion that should be retained in the "Want" category ("Want" Criterion \#31, Section B-3.2.3). 


\section{B-2.2.5 [9] Locate Within Core Infrastructure Area}

The INL Comprehensive Land Use and Stewardship Report (Kostelnik 2005) implements DOE Policy 430.1, Land and Facility Use Planning (DOE 1996). The report integrates mission, economic, ecologic, social, and cultural factors in a comprehensive plan to guide growth and development of INL. The report is a central reference for siting any facility within INL. One aspect of land use planning considers the evolution of existing facilities and the addition of new facilities. Many existing facilities are scheduled for, or are in the process of, decommissioning and the INL mission will continue to identify new facilities. Over the next 30 years, cleanup activities at each Waste Area Group (WAG) will be completed and the sites will be under the INL Long-Term Stewardship program. There may be portions of an individual WAG suitable for location of a LLW disposal facility. For this reason, it is reasonable to retain evaluation of FFA/CO sites to allow gradational evaluation of each WAG. The Land Use and Stewardship Report (Kostelnik 2005) identifies a 30-year land use scenario that defines a "core infrastructure" area. Siting a facility in this area ensures it is consistent with overall land use planning. Consequently, it is appropriate that this criterion be considered further in the "Want" criteria category ("Want" Criterion \#37, Section B-3.3.1).

\section{B-2.2.6 [10] Locate Near Utilities and Transportation}

This criterion was included in two of the previous siting studies in a similar context. Infrastructure includes haul routes, emergency services, and utilities (power, water, and communications). Haul routes are an obviously important consideration for siting a LLW disposal facility and a site on or near a road to the waste generators is preferable. Emergency services are a consideration under DOE Guide 420.1-1 and DOE Guide 420.1-2. There are several facilities on INL where services such as fire control and medical/first aid are available and a preferable location would be relatively close to these facilities. A site location near existing utilities and transportation allows necessary infrastructure to be provided while minimizing potential impacts to offsite areas. Utility requirements for construction, operation, and maintenance of the facility are expected to be minimal and could be brought to the site (e.g., generators). No water is required for operations, and neither potable water nor sewers are identified in the technical and functional requirements for the facility. If utilities are required but not available, they could be routed to a remote site with additional cost to the project. Including this criterion allows consideration (and minimization) of potential offsite impacts associated with providing utilities and transportation to a candidate site. For these reasons, siting a location near transportation and utilities (particularly within 1 mile) is preferable, but not required so this criterion is recommended to be considered further in the "Want" category ("Want" Criterion \#39, Section B-3.3.3).

\section{B-2.2.7 [11] Avoid Critical Habitats of Endangered Species}

This criterion is found in two of the studies. The criterion focuses on The Endangered Species Act (ESA) of 1973 (16 U.S.C. $\$ \S 1531-1544$ ) and implementing regulations. The ESA requires that any activity authorized by the Environmental Protection Agency (EPA) is not likely to jeopardize the continued existence of any listed species or adversely affect its critical habitat. ESA-listed species include those that have been designated as endangered or threatened and may also include those that have been proposed for listing or are candidate species. Classification of ESA-listed species include the following definitions:

- $\quad$ Endangered: Species in danger of extinction throughout all or a significant portion of its range.

- $\quad$ Threatened: Species likely to become endangered within the foreseeable future throughout all or a significant portion of its range. 
- $\quad$ Proposed: Species proposed in the Federal Register to be listed as endangered or threatened under Section 4 of the ESA.

- $\quad$ Candidate: Species for which U.S. Fish and Wildlife Service (FWS) has on file sufficient information on biological vulnerability and threats to support a proposal to list as endangered or threatened.

The ESA requires that any activity authorized by EPA is not likely to jeopardize the continued existence of any threatened or endangered species or adversely affect its critical habitat. Generally, the EPA interpretation of this obligation is to prohibit the siting of disposal facilities within endangered or threatened species habitat.

There are no threatened and endangered (T\&E) species present at INL; however, there are several species currently being considered for listing (e.g., sage grouse, pygmy rabbit). Habitat surveys have been conducted at INL areas as part of the DOE Environmental Surveillance, Education, and Research (ESER) Program. A natural resource survey will be conducted as part of the NEPA analysis to determine if there is an impact. In the absence of identified critical habitat it is important that sensitive habitat be considered further in the "Want" criteria category (see "Want" Criterion \#49 "Avoid Ecologically Sensitive Habitat", Section B-3.4.3).

\section{B-2.3 "Must" Criteria Considered but Not Used}

A number of the criteria considered by previous studies or identified during this siting evaluation are not applicable to a LLW facility, have been addressed in other criteria, or pertain to characteristics not found at INL. These criteria are listed below and the evaluation leading to a conclusion of "considered but not used" is summarized. A total of six criteria were considered but not used for this siting evaluation.

\section{B-2.3.1 [12] Must be Located 1 Mile or More from Category 1 Facility}

This criterion is found only in the Idaho Waste Processing Facility (IWPF) siting study. A Hazard Category 1 facility is defined in DOE Order 5480.23 as any nuclear facility whose hazard analysis shows the potential for significant offsite consequences. The IWPF siting study noted that there was no requirement for facility distance from public roads or other facilities "except as dictated by performance assessments of public exposure to radiation, toxic air pollutants, etc., at specific facilities." A cumulative effects analysis is completed as part of the NEPA process and again as part of the safety analysis process. The evaluations are conducted during the NEPA process of selecting the preferred site and again to evaluate potential risk to human health and the environment as part of the design process. For these reasons, this criterion is not appropriate for preliminary siting of an onsite Remote-Handled LLW Disposal Facility and is not considered further.

\section{B-2.3.2 [13] Avoid Maximum Mackay Dam Failure Flood Elevation}

This criterion is found only in the NPR study. Because the NPR siting evaluation was for an above-ground stationary reactor facility, consideration of a seismically-induced Probable Maximum Flood (PMF) was appropriate. For the NPR study, the PMF was defined as failure of Mackay Dam. The requirement is specified in 10 CFR 100, Subpart B Appendix VI(c) as "The design basis for seismically induced floods and water waves from either locally or distantly generated seismic activity... shall be taken into account in the design of the nuclear power plant so as to prevent undue risk to the health and safety of the public." The NRC requirement for stationary nuclear reactors is not applicable to siting a LLW disposal facility. 
In addition, this siting evaluation process includes both a "Must" Criterion ( $\# 2$ ) and a "Want" Criterion (\#29) to include assessment of flooding. The other three siting studies did not consider the PMF, rather they looked at the 100-year flood. Given the diversity of approaches to developing a flooding criterion, this evaluation relies on guidance found in 10 CFR 61.50(5), namely that "waste disposal shall not take place in a 100-year floodplain," and DOE-STD-1020.2002, specifying consideration of the 500 -year flood. "Must" Criterion \#2 ensures that the disposal facility will not be located in the 500-year floodplain, and "Want" Criterion \#29 evaluates a location's proximity to a 1,000-year floodplain. Consequently, the PMF was eliminated as an evaluation criterion and is not considered further.

\section{B-2.3.3 [14] Avoid High Surface Erosion Areas}

This criterion is found only in the Idaho Comprehensive Environmental Response, Compensation, and Liability Act (CERCLA) Disposal Facility (ICDF) study. It can be considered part of the more general requirement of DOE Order $435.1 \mathrm{M} \mathrm{IV(1)(c)} \mathrm{that} \mathrm{states} \mathrm{a} \mathrm{facility} \mathrm{"shall} \mathrm{be} \mathrm{sited} \mathrm{to} \mathrm{achieve}$ long-term stability and to minimize, to the extent practical, the need for active maintenance following final closure." DOE Guidance 421.1-2, Appendix C, also identifies excessive rain, snow, and landslides as Natural Phenomena Hazards to be addressed. Hackett et al. (1994), in a study that presented implications for long term stability and erosion at the RWMC, noted that the eastern Snake River Plain is a subsiding basin that continually is resurfaced by sedimentation and lava-flow emplacement. Deep erosion is not an issue for most INL areas. A very small portion of INL has what might be considered "steep slopes" that could be prone to landslides. These areas are found in the northwest and north ends of the site in the areas potentially affected by seismic activity (Criterion \#1). The locations in these areas failed Criterion $\# 1$ and thus are not considered for further evaluation. None of the other candidate sites are located in areas of "steep slopes" and consequently, this criterion is not considered for further evaluation.

\section{B-2.3.4 [15] Avoid Groundwater Discharge Areas}

This criterion is not found in any of the previous siting studies. However, groundwater discharge to the surface within a proposed disposal area is prohibited in 10 CFR 61.50(8). Groundwater (i.e., the water table) occurs from 200 to $900 \mathrm{ft}$ below land surface (bls), the shallow depths at the north end of INL, and deeper depths at the south end of INL. There is no likelihood that groundwater discharge will occur at any location within the INL boundary under current climatic conditions. Even in a much wetter climate that might develop over the next 10,000 years, any groundwater discharge is likely to be limited to floodplains from which sites are already eliminated from consideration. Thus, groundwater discharge was eliminated as an evaluation criterion and is not considered further.

\section{B-2.3.5 [16] Avoid Groundwater Intrusion}

This criterion is presented in only the ICDF siting evaluation. It is found in DOE Manual 435.1 and in 10 CFR 61.50(7). As noted in Criterion \#15, depth to groundwater on INL ranges from 200 to $900 \mathrm{ft}$ bls, the shallow depths at the north end of INL, and the deeper depths at the south end of INL. There is no likelihood that groundwater intrusion will occur at any location within the INL boundary under current climatic conditions. Groundwater intrusion would only be possible with an increase in water-table elevation from between 200 to $900 \mathrm{ft}$ bls to less than $29 \mathrm{ft}$ bls. Such a change in the hydrologic regimen could conceivably occur within a 10,000-year period if the climate became cooler and wetter with associated increased streamflow and expansion of pluvial Lake Terreton, in which case the groundwater table in the immediate vicinity of streams or lakes might be close to ground surface. This indicates that a site near the south end of INL that is outside of the floodplain identified via paleohydrologic studies and outside the footprint of Lake Terreton (in the northern portion on INL) would be preferable. These areas are addressed by Criterion $\# 29$. 
Other mechanisms for "intrusion" of water into the disposal facility include flooding (covered by Criterion \#2 and Criterion \#29) and infiltration from surface water accumulation (covered by Criterion \#31), and intrusion of perched water (covered by Criterion \#32). Consequently, groundwater intrusion was eliminated as an evaluation criterion and is not considered further.

\section{B-2.3.6 [17] Consider Population Density Limits}

This criterion is included only in the NPR study and the requirement is identified as 10 CFR 100 . The requirement states that "The Commission will take the following factors into consideration in determining the acceptability of a site for a stationary power reactor: (a) Population density and use characteristics of the site environs..." The NRC requirement for stationary nuclear reactors is not applicable to siting a LLW disposal facility.

DOE Order 435.1 broadly addresses this criterion by stating that the siting evaluation should "consider human activities," and 10 CFR 61.50(3) focuses on the impact population growth may have on performance objectives of the facility. In the case of INL, the surrounding census blocks have populations that range from a low of 0 to a high of 150 persons per census block group. The primary land use is agricultural with a population density of less than 30 people per square mile within $50 \mathrm{mi}$ of INL. A buffer zone within INL (approximately $500 \mathrm{mi}^{2}$ ) has been set aside for grazing. The nearest cities with populations greater than 11,000 are located more than $50 \mathrm{mi}$ to the east of INL. In addition, INL will remain under federal government management and control for the next 100 years, defining an industrial development scenario that will limit growth in population density. No residential development is planned within the boundary of INL and no new major developments are expected to occur on lands next to INL. As a result, this criterion was eliminated as an evaluation criterion and is not considered further.

\section{B-2.4 Recommended "Must" Criteria}

The result of the screening process documented above is selection of four "Must" criteria that are used to eliminate those site locations that do not meet the minimum requirements for siting a LLW disposal facility. The recommended "Must" criteria for siting an onsite remote-handled LLW disposal facility are:

1. Must not be located within 5 mi of a capable fault (Section B-2.1.1)

2. Must not be located in a 500-year floodplain (Section B-2.1.2)

3. Must not be located in an area of less than 5 acres (Section B-2.1.3)

4. Must not be located in a wetland (Section B-2.1.4).

\section{B-3. "WANT" CRITERIA SCREENING AND SELECTION}

The list of "Want" criteria was developed from regulations or DOE orders and from previous siting studies. Seven criteria were also carried over for further consideration from the "Must" criteria screening process (Section B-2). A total of 43 "Want" criteria were identified, 10 of which were not documented in previous siting studies. Elimination of duplicate criteria resulted in a total of 37 "Want" criteria, which are numbered 18 through 53, resulting in a unique numerical identifier for each criterion. Twenty-one of the 37 are identified for inclusion as "Want" criteria for siting an onsite remote-handled LLW disposal facility. The remaining 16 were considered but not used. Section B-3.5 summarizes the 21 criteria that are used in this siting study. 
A review of the criteria indicated that organization by subject area would facilitate the screening process significantly by allowing side-by-side comparison of criteria that address similar data types. This contributes to application of the scoring system in a more uniform fashion. Consequently, criteria were divided into four subject areas and evaluated in the following sections:

- $\quad$ Section B-3.1, Geology

- $\quad$ Section B-3.2, Hydrology

- $\quad$ Section B-3.3, Land Use

- $\quad$ Section B-3.4, Natural Resources.

Each subsection presents a table of criteria appropriate for that subject area. The table identifies criteria from previous studies and those criteria considered in this siting evaluation. The right hand column indicates those "Want" criteria that were selected for use in this evaluation or considered but not used in this evaluation.

\section{B-3.1 Geology}

Criteria that are based on an understanding of geologic conditions allow for evaluation of site-specific characteristics that affect facility design, performance, and potential for adverse impacts from natural phenomena hazards (e.g., seismic or volcanic events). Site-specific characterization data useful during design are primarily geotechnical (e.g., seismic, soil type, foundation properties) and will certainly include thickness of surficial sediments, as this will affect the number of disposal containers that could be stacked vertically. Site-specific characterization data, which are useful when conducting a performance assessment, include sediment type (e.g., sand, silt, clay) and total interbed thickness needed to estimate retardation of contaminant migration or attenuation.

The criteria identified in Table B-2 provide a means of ranking candidate sites within the broad subject area of "Geology." The left-hand column identifies criteria used in previous studies and the middle column identifies the criteria screened for use in this evaluation. The right-hand column indicates criteria that were retained for use in this evaluation and those that were considered but not used. The sections that follow provide a discussion of each criterion in the context of siting an onsite remotehandled LLW disposal facility and indicate whether the criterion is retained or considered but not used for use in this siting evaluation. 
Table B-2. Comparison of geology subject area "Want" criteria considered by previous INL siting studies with those identified for use in this siting study.

\begin{tabular}{|c|c|c|}
\hline $\begin{array}{l}\text { "Want" Criteria Identified from } \\
\text { Previous Siting Evaluations }\end{array}$ & $\begin{array}{c}\text { "Want" Criteria Considered for Remote-Handled } \\
\text { LLW Disposal Facility Evaluation }\end{array}$ & \\
\hline Locate in an area with thick surficial sediment & 18. Maximize surficial sediment thickness & $\checkmark$ \\
\hline Not considered previously & 19. Maximize sediment thickness continuity & $\checkmark$ \\
\hline Impede downward migration of contaminants & 20. Maximize retardation to attenuate migration & $\checkmark$ \\
\hline Not considered previously & 21. Maximize interbed continuity & $\checkmark$ \\
\hline Minimize potential impacts from earthquakes & 22. Minimize impact from earthquakes & $\checkmark$ \\
\hline Maximize distance from volcanic exclusion zone & 23. Maximize distance from volcanic hazard zones & $\checkmark$ \\
\hline $\begin{array}{l}\text { Locate where discriminatory monitoring can be } \\
\text { achieved }\end{array}$ & 24. Locate to facilitate discriminatory monitoring & $\checkmark$ \\
\hline Not considered previously & 25. Availability of geotechnical data & $\checkmark$ \\
\hline Not considered previously & 26. Availability of characterization data & $\checkmark$ \\
\hline Not considered previously & 27. Avoid areas of known or probable subsidence & $\bullet$ \\
\hline Minimize cost of new excavation & 28. Minimize cost of new excavation & - \\
\hline
\end{tabular}

\section{B-3.1.1 [18] Maximize Surficial Sediment Thickness}

This criterion was included in one of the previous siting studies. Sediment thickness is one variable in ensuring that the requirements of DOE Manual 435.1 IV M(1)(a)(1) (must accommodate the predicted volume of waste) are met. This criterion separates those areas where surficial sediments are thicker from those where basalt occurs at or near the surface. Excavation of basalt bedrock for vault emplacement would be significantly more costly than excavation of surficial sediment. The conceptual design calls for a depth of about $29 \mathrm{ft}$ for a two-cask vertical configuration and about $39 \mathrm{ft}$ for a three-cask configuration. Thus, a location with more than $39 \mathrm{ft}$ of surficial sediment is more desirable than a location with less surficial material. A desirable location would have coarse-textured surficial sediments that allow rapid drainage of soil in which vaults are constructed, in order to minimize intrusion of water into disposal vaults Attenuation of contaminant migration, which is discussed in Section B-3.1.2 (Criterion \#20), is also an important site evaluation criterion. Locating a site with maximum surficial sediment thickness is an appropriate criterion and it is retained in the "Want" category for use in this siting evaluation.

\section{B-3.1.2 [19] Maximize Sediment Thickness Continuity}

This criterion was not included in any of the previous siting studies. The importance of maximizing surficial sediment thickness was discussed in Section B.3.1.1 and the general requirements for interbed thickness are discussed in Section B-3.1.3. Variability and uncertainty in surficial sediment thickness across a potential site are as important as total surficial sediment thickness for two important reasons. Higher variability can affect vault design of a remote-handled LLW facility and variable thickness increases the range of potential earthquake ground motions (discussed in Section B-3.1.5), which can significantly affect engineering design. Uniform surficial sediment thickness results in a narrower range of predicted ground motion and a commensurately narrower range of engineering design. Increased variability requires that the engineering design be sufficiently robust to span the range of predicted ground motion. 
The benefit of coarse textured surficial sediments noted in Section B-3.1.1 above is offset by the corresponding increase in radionuclide migration rate through coarse sediments. This amplifies the importance of "Want" criteria \#20 and \#21 below (assessment of radionuclide migration). Locating a site with greater surficial sediment continuity is an appropriate criterion and it is retained in the "Want" category for use in this siting evaluation.

\section{B-3.1.3 [20] Enhance Retardation to Minimize Migration}

Evaluation of radionuclide migration was included in two of the previous siting studies. DOE Orders 435.1 and 420.1B specify geologic, geotechnical, and hydrologic criteria that are needed to demonstrate that "migration pathways are predictable." NRC guidance for siting a LLW facility states that the various criteria are to be evaluated in the context of meeting "the performance requirements of Subpart C" (i.e., 10 CFR 61.40-44). The intent of both DOE orders and NRC guidance is to assess site characteristics that influence contaminant migration, should a release occur. The DOE orders are not prescriptive regarding which characteristics should be considered; however, the NRC guidance is useful in identifying appropriate criteria. In addition, a longer post-closure timeframe (e.g., 10,000 years) may be considered in a performance assessment to determine peak dose. Thus a radionuclide migration criterion is designed to provide an important relative measure of the potential for radionuclide retardation or attenuation at each candidate disposal facility site.

Locating a waste disposal facility in an area with characteristics that impede the downward migration of contaminants protects the aquifer in the event of a release. The timeframe identified in DOE M 435.1 IV P(2) and (3) for evaluation of radionuclide release and migration in a performance assessment is 1,000 years. Consideration of longer post-closure timeframes (e.g., 10,000 years) can be accommodated with adjustments in weighting or scoring factors. The capability of contaminants to reach the water table (i.e., vertical or downward migration) is directly dependent on: (1) the depth to the water table, and (2) the physical and geochemical characteristics of the material between land surface and the water table (i.e., the vadose zone). Abundant physical data (primarily information gleaned from boreholes) and modeling results have been compiled for many areas at INL.

Depth to groundwater at INL ranges from about 200 to $900 \mathrm{ft}$ bls. In the central portion of INL (where many existing facilities are located), depth to groundwater is about $500 \mathrm{ft}$ bls. When evaluating candidate sites, a location with a deeper water table is preferable to one with a shallower water table. In general, the stratigraphic section at INL consists of variable thickness surficial sediments overlying numerous basalt flows interspersed with sedimentary interbeds. Two measures that may be used in site evaluation relative to contaminant migration include cumulative interbed thickness and total thickness of only the fine-grained (e.g., silt or clay) portion. Interbeds, especially those with a high percentage of finegrained material, tend to impede vertical migration relative to migration through basalt. The basalt flows beneath INL are fractured, brecciated, and vesicular. Because of these characteristics, performance assessments usually assume rapid downward migration through basalt with attenuation occurring in interbeds. Fine-grained materials, such as clay or fine silts, have lower hydraulic conductivities and higher sorption coefficients than do coarser materials such as sands and gravels. Thus, relative to siting, a desirable location would have coarse-textured surficial sediments that allow rapid drainage of soil in which vaults are constructed (to minimize intrusion of water into disposal vaults) and a large cumulative thickness of fine-grained material in interbeds to maximize radionuclide retardation.

Because of the potential for release of radionuclides from the waste, evaluation of geological features that affect contaminant migration is appropriate to ensure data are available to support the performance assessment and composite analysis required by DOE Order 435.1 to address long-term migration and impacts of contaminant release. 


\section{B-3.1.4 [21] Maximize Interbed Continuity}

This criterion was not included in any of the previous siting studies. As with continuity in surficial sediment thickness, it is important that continuity in interbed sediment thickness and distribution be maximized. An important siting criterion is consideration of the lateral continuity of interbeds. When evaluating candidate sites, a location with interbeds that can be correlated across the entire site footprint based on lithologic logs from wells is more preferable than a site with short discontinuous interbeds. As discussed in Sections B-3.1.3, the stratigraphy underlying INL consists of variable thickness surficial sediments overlying numerous basalt flows interspersed with sedimentary interbeds. Contaminant migration rates are retarded in the interbeds, but are retarded very little if any in the basalts. Thin, discontinuous interbeds increase the potential of contaminants traveling through basalts, unimpeded. Thick, continuous interbeds reduce this potential, and increase the likelihood of contaminant migration being retarded, allowing more time for radioactive decay, reducing the potential impacts to groundwater. The ability to predict the amount of retardation is highly correlated to variability and/or uncertainty in interbed thickness. Higher variability and more uncertainty in interbed thickness leads to more uncertain transport, concentration, and health impact predictions. Locating a site with greater interbed continuity (minimizing radionuclide migration) is an appropriate criterion and it is retained in the "Want" category for use in this siting evaluation.

\section{B-3.1.5 [22] Minimize Impact from Earthquakes}

An evaluation of seismic events was included in three of the previous siting studies and this criterion was recommended for further consideration as a result of the "Must" screening (see Criterion \#5). Both DOE Orders 435.1 and 420.1B (with manuals, guides, and sub tier standards) identify seismic hazard as a necessary component of the siting evaluation process. The criterion is also found in NRC LLW facility siting guidance where the statement "areas must be avoided where tectonic processes such as faulting, folding, seismic activity, or volcanism may occur..." (10 CFR 61.50(9)) highlights the importance of understanding the tectonic nature of a candidate site. Although NRC guidance is not applicable to DOE facilities, it is clear through similarity of wording that the requirements of DOE Orders 435.1 and 420.1B for natural phenomena hazard assessment considered the intent of NRC guidance. A seismic impact criterion is designed to provide a relative measure of the potential for seismic-induced damage at each candidate disposal facility site. Regional seismic activity has been monitored at INL, with a seismic monitoring network established in 1973.

The eastern Snake River Plain is regarded as aseismic relative to the surrounding basin-and-range province. Figure C-3 (Appendix C) presents the 0.2-second spectral period peak ground acceleration with $2 \%$ probability of exceedance in 50 years for the region, including the eastern Snake River Plain and INL. Based on this USGS data, predicted ground motion values for all sites within the boundaries of INL are relatively low, ranging from less than $32 \% \mathrm{~g}$ (percentage of gravitational acceleration) to $40 \% \mathrm{~g}$. These values are indicative of the low rates of historic earthquake occurrence in the area immediately surrounding the site, the low magnitudes of such earthquakes, and the distance from Quaternary faults capable of generating larger earthquakes.

DOE-STD-1022-94 includes consideration of "propensity for ground motion" and "susceptibility of surficial sediments to failure from ground motion." Both are important because the potential impact from vibratory ground motion derived from earthquakes is amplified in areas of specific surficial sedimentary lithologies and increased surficial sedimentary thickness. Across INL, sedimentary lithologies range from loess to fluvial deposits to fine-grained lake deposits. Sedimentary thickness ranges from zero in the vicinity of basalt flows to hundreds of feet in areas of lake and river deposits. The remote-handled LLW screening process did account for surficial sediment lithology and thickness. However, these surficial sediment characteristics will be further evaluated during site characterization 
activities to determine a site classification that will in turn be used to evaluate spectral acceleration to be used in facility design.

The current conceptual design indicates that the onsite remote-handled LLW disposal facility performance classification is PC-1, which will require adherence to Seismic Use Group I (IBC 2000). If the performance category should change through the design process once the preferred site is identified, a detailed seismic hazard analysis based on INL, USGS, and other seismic datasets may be needed. If needed, this activity would be conducted during the Natural Phenomena Hazards assessment.

Although the potential impact of seismic events to INL facilities has been shown to be relatively low, this criterion is appropriate for the "Want" category because of the potential for tectonic processes in the region surrounding the eastern Snake River Plain and because of varying thicknesses of sedimentary deposits at candidate locations.

\section{B-3.1.6 [23] Maximize Distance from Volcanic Hazard Zones}

This criterion was included in two of the previous siting studies and was also recommended for further consideration as a result of the "Must" screening (see Criterion \#6). Both DOE Orders 435.1 and 420.1B (with sub tier manuals, guides, and standards) recognize the hazard associated with volcanic activity. In addition, one NRC characterization objective (10 CFR 61.50(9)) states that "areas must be avoided where tectonic processes such as faulting, folding, seismic activity, or volcanism may occur..." Volcanic vents or related fissures could compromise the performance of the disposal facility such that there may be a release of contaminants. Inundation by lava flows could bake the soil cap over the vaults and potentially heat the upper vault sections, resulting in an impact on long-term performance assessment. Dike intrusion can result in surface deformation in the form of small normal faults, fissures, and grabens, and can produce associated volcanic earthquakes (Smith et al. 1996). Studies at INL (Hackett, Smith, and Khericha 2002) suggest the recurrence interval of volcanic events is on the order of 16,000 to 100,000 years, indicating that, while there is a risk, its probability is lower than the risk of seismic or flooding events. Though the risk is lower than other natural phenomena hazards, it is appropriate to retain this criterion in the "Want" category for the site evaluation.

\section{B-3.1.7 [24] Locate to Facilitate Discriminatory Monitoring}

A monitoring criterion was included in one of the previous siting studies. Monitoring is not an explicit siting requirement within DOE Manual 435.1 Section IV M, but it is required under Section IV R where it is stated that "The environmental monitoring program shall be designed to include measuring and evaluating releases, migration of radionuclides, disposal unit subsidence, and changes in disposal facility and disposal site parameters which may affect long-term performance." It is also an NRC siting criterion that states a site must be "capable of being characterized, modeled, analyzed and monitored" (10 CFR 61.50(2)). A discriminatory monitoring criterion evaluates whether or not existing conditions at each the candidate disposal facility site may impact development of a long-term monitoring program.

The design and installation of monitoring systems (i.e., air, soil, and groundwater) across INL demonstrates that an adequate monitoring system can be achieved. However, the presence of existing contamination at a candidate site will influence the relative success of a discriminatory monitoring program. In the case of a remote-handled LLW disposal facility, radionuclide contamination would be undesirable but chemical contamination (e.g., tetrachloroethene) would not have a significant impact. The INL operates nuclear facilities so a "Want" evaluation criterion related to monitoring of previously existing contamination and the disposal facility itself is appropriate. 


\section{B-3.1.8 [25] Availability of Geotechnical Data}

This criterion was not included in any of the previous siting studies. However, it was recommended for consideration as a result of the "Must" screening process (Section B-2.2.3), is identified in DOE Manual 435.1 M IV M(1)(b), and is an element of DOE-STD-1022-94 (implemented through DOE Guide 420.1-2) for completion of Natural Phenomena Hazards characterization and assessment. The standard outlines those investigations required to adequately conduct hazard evaluations, engineering analysis and design, assessment of local soil effects on ground motion, carry out soil-structure interaction analyses, and assess potential of soil failure or deformation induced by ground shaking. Data needed for these studies include soil-rock profiles and geotechnical data, including soil classification, strength, compressibility, density, and shear wave velocity. Detailed geotechnical fieldwork is not a component of a siting evaluation and geotechnical fieldwork is normally conducted once a preferred site has been selected through the NEPA process. At the siting evaluation stage, a site that has existing geotechnical data for assessment of the above conditions is preferable over a site with limited or no data.

Consequently, this criterion is appropriate for evaluation of the onsite Remote-Handled LLW Disposal Project facility candidate sites and is retained in the "Want" category.

\section{B-3.1.9 [26] Availability of Characterization Data}

An evaluation of existing characterization data was not included in any of the previous siting studies. However, it was recommended for consideration as a result of the "Must" screening process (Section B-2.2.3) and is identified in DOE Manual 435.1 M IV(1). Characterization is required to support the natural phenomena hazards assessment defined in DOE Order 420.1B. In addition, NRC guidance notes that a site "shall be capable of being characterized..." The availability of existing characterization data is then an important element of a siting evaluation. Much of the baseline characterization data (e.g., geology, seismology, surficial geology, volcanology, etc.) are discussed under other criteria. From this, it is apparent that there is an abundance of characterization data. An additional dimension is characterization with depth. Existing boreholes provide this information so an evaluation of the spatial distribution of boreholes will provide a relative measure of available characterization data at different locations within INL. Availability of characterization data is a valuable component of a siting evaluation and consequently, it is retained in the "Want" category.

\section{B-3.1.10[27] Avoid Areas of Known or Probable Subsidence}

Avoidance of areas susceptible to subsidence was not included as a criterion in any of the previous siting studies. This is generally a concern in a region with karst topography or where there are abundant natural resources and associated abandoned underground mines used to exploit those resources. On INL, there is no karst topography (though a slight possibility exists in Paleozoic limestone bordering INL to the northwest) and no known abandoned mines. However, the volcanic terrain can and does include lava tubes in surficial flows and buried within the layers of basalt. Should a candidate site be located on basalt, subsidence related to collapse of a lava tube could pose a concern. There is no cost-effective way to obtain the type of subsurface characterization needed to assess this condition at each candidate site. Consequently, this criterion is considered but not used as an evaluation criterion but it is noted that it may become a data gap requiring further characterization if the preferred site is located directly on basalt.

\section{B-3.1.11[28] Minimize Cost of New Excavation}

Minimizing the cost of new excavation was included as an evaluation criterion in one of the previous siting studies. It is not mentioned or required in DOE Orders 435.1 or $420.1 \mathrm{~B}$ and it is not mentioned in the NRC guidance. The cost of excavation is considered in overall project planning and during design. The cost of excavating in basalt will be substantially higher than excavation in sediment. 
Using cost as an evaluation criterion then would bias candidate site evaluation away from basalt and toward sedimentary deposits. A different criterion, "maximize surficial sediment thickness"

(Criterion \#18), ranks sites by sediment thickness, which is a proxy for relatively low excavation cost. Consequently, a separate criterion for relative excavation cost is not retained in the "Want" category.

\section{B-3.2 Hydrology}

An understanding of site hydrology (both surface water and groundwater) is important when siting a LLW disposal facility for several reasons, including protecting the Snake River Plain Aquifer (SRPA) from possible contamination and the potential impacts to facility performance due to flooding, ponding, or inundation.

The criteria identified in Table B-3 provide a means of ranking candidate sites within the broad subject area of "Hydrology." The left-hand column identifies criteria used in previous studies and the middle column identifies the criteria screened for use in this evaluation. The right-hand column indicates criteria that were retained for use in this evaluation and those that were considered but not used. The sections that follow provide a discussion of each criterion in the context of siting a remote-handled LLW disposal facility and indicate whether the criterion is retained or considered but not used for use in this siting evaluation.

Table B-3. Comparison of hydrology subject area "Want" criteria considered by previous INL siting studies with those identified for use in this siting study.

\begin{tabular}{lll}
\hline \multicolumn{1}{c}{$\begin{array}{c}\text { "Want" Criteria Identified from } \\
\text { Previous Siting Evaluations }\end{array}$} & \multicolumn{1}{c}{ "Want" Criteria Considered for Remote-Handled } \\
\hline Minimize proximity to the 500 -year floodplain & 29. Minimize proximity to floodplains \\
Reduce risk of release to a stream & Captured in \#29 \\
Not considered previously & 30. Avoid aquifer recharge areas \\
Minimize local flooding and ponding & 31. Avoid areas of surface water flooding/ponding & $\checkmark$ \\
Avoid areas over perched water & 32. Avoid perched water & $\checkmark$ \\
Not considered previously & 33. Avoid wellhead protection areas \\
Maximize ground water transmissivity & 34. Maximize ground water transmissivity & $\checkmark$ \\
Minimize depth of wells for water supply & 35. Minimize depth of wells for water supply & $\bullet$ \\
Not directly above aquifer & 36. Not directly above aquifer & \\
\hline$\checkmark=$ Criterion included in the Remote-Handled LLW Disposal Project facility siting evaluation. \\
\end{tabular}

\section{B-3.2.1 [29] Minimize Proximity to Floodplains}

Three streams from watersheds adjacent to the eastern Snake River Plain drain onto INL and include the Big Lost River, Little Lost River, and Birch Creek. Of these streams, the Big Lost River is the stream most likely to contribute flood flows to INL. The channel of Birch Creek is located in the northern part of INL and drains to playas and low-lying areas in the vicinity of Test Area North. The Little Lost River does not flow across INL but drains into a terminal playa near Howe, Idaho.

DOE Guide 420.1-2 stipulates that structures must not be located in floodplains or in areas that are potentially subject to flooding due to dam failures to avoid consequences of natural hazard phenomena. 
At least two criteria included in previous siting studies were derived from the potential for stream flooding and subsequent facility inundation. One criterion was intended to minimize the proximity to the 100 -year floodplain. The other was to reduce risk of release to a stream. A single criterion (minimize proximity to floodplains) was developed for this siting study to encompass these two criteria. This criterion applies to those areas outside the 500-year floodplain. A site that is located on floodplain deposits, but outside the 500-year floodplain, may be subjected to inundation during a larger-magnitude flood, as discussed below. The potential for flooding to those sites that are located outside of the floodplain is controlled in part by the elevation above the floodplain.

A paleohydrology study performed by the Bureau of Reclamation to assess flood hazards with recurrence intervals ranging from 20 to 20,000 years at INL near the Big Lost River (Ostenaa and O'Connell 2005) estimated flood flows and inundated areas that could impact site locations near the Idaho Nuclear Technology and Engineering Center (INTEC) and the Test Reactor Area. A performance assessment conducted for recommended sites in the area studied by Ostenaa and O'Connell for a post-closure time period of 1,000 years or longer would consider the likelihood of facility flooding due to floods with longer recurrence intervals (e.g., 10,000 years).

In addition to flooding along streams in response to normal meteorological cycles, a return to cooler, wetter conditions due to climatic change could result in glacial melt flooding and expansion of pluvial Lake Terreton in the northern part of INL. Computed inundation maps for the vicinity of INTEC and RTC are presented in Figure B-2 for the 500-year, 1,000-year, and 10,000-year floods. These maps indicate the change in inundation for sites located outside 500 -year flood plain. Further consideration is given to sites located within the footprint of ancestral Lake Terreton. The effect of glacial cycle flooding is best accommodated in this criterion by evaluation of proximity of a potential site to the boundary of historic Lake Terreton.

The criterion of avoiding floodplains and the footprint of Lake Terreton is part of an overarching objective of avoiding sites where the groundwater table (perched or regional) may rise to within $29 \mathrm{ft}$ of ground surface or where surface water ponding or flooding could inundate a disposal site within the post-closure performance assessment period. Minimizing the potential for inundation from stream flooding events and for subsequent radionuclide release to the environment is considered to be important. Therefore, this criterion is retained in the "Want" category. A detailed flooding potential analysis should be conducted for the site selected in the NEPA process based on local topographic and hydrologic datasets.

\section{B-3.2.2 [30] Avoid Aquifer Recharge Areas}

Recharge to the SRPA at INL is primarily derived from infiltration of streamflow in the Big Lost River and its associated surface water features. Significant recharge areas on INL include the channel of the Big Lost River, the INL spreading areas near the Radioactive Waste Management Complex (RWMC), which are used for diversion of excess streamflows to protect downstream facilities, and terminal playas in the north-central part of INL. 

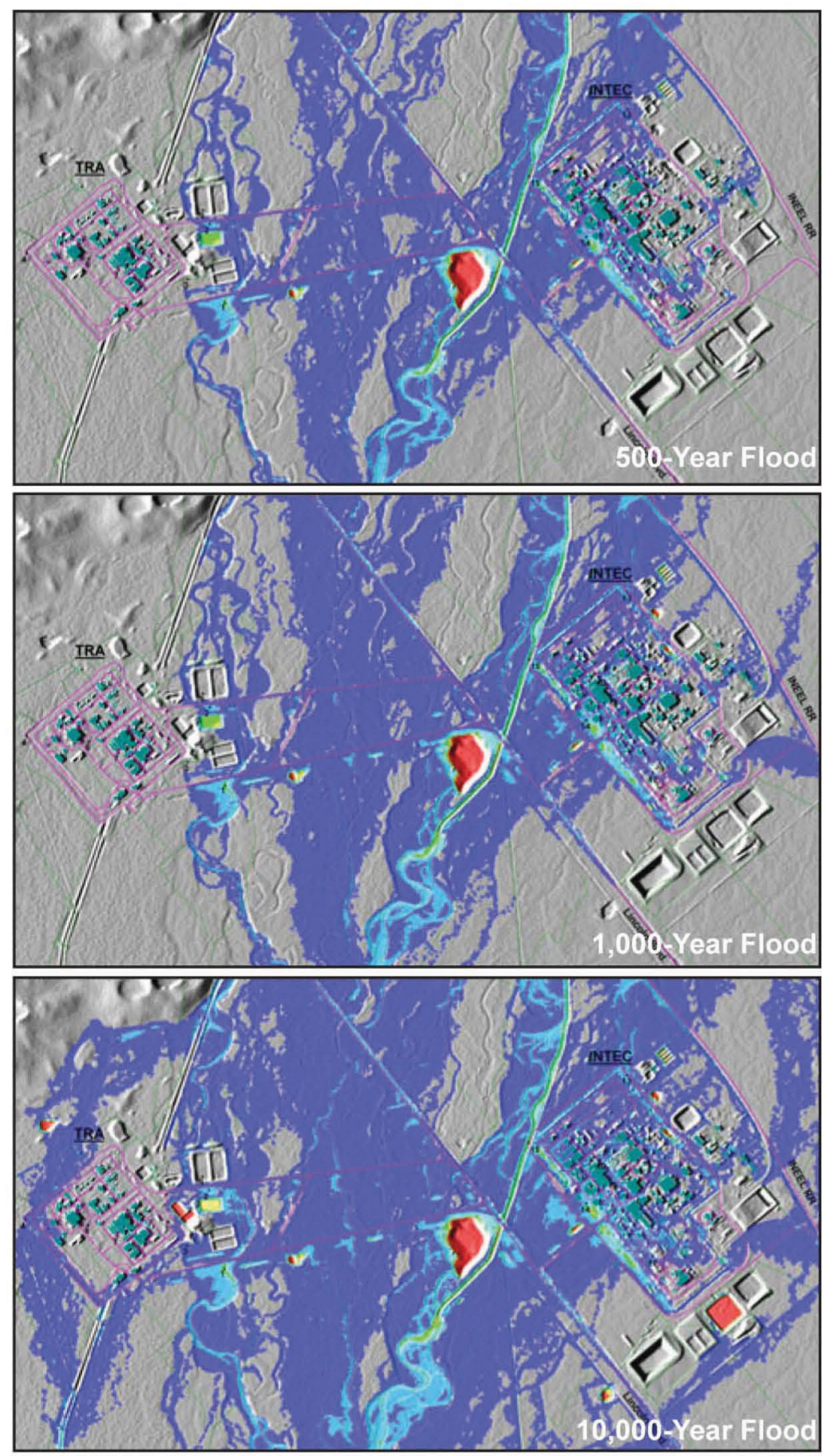

\section{Legend}
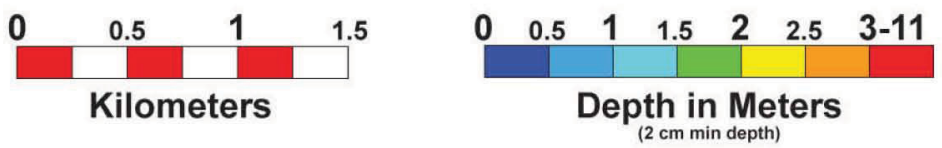

NW10-002

Figure B-2. Comparison of the estimated 500-, 1,000-, and 10,000-year floods (Ostenaa and O'Connell 2005). 
Some source of recharge occurs from infiltrating streamflows along the channels of the Little Lost River and Birch Creek. Most of this recharge occurs upgradient from INL, with infrequent flows into the terminal playas in the north-central part of INL. Some Birch Creek flows are diverted to a power plant upstream of INL and return flows are directed onto the north end of INL where they infiltrate along the diversion channel, to a gravel pit, and infrequently to terminal playas. Aquifer recharge areas for these two sources consist of the terminal playas and the Birch Creek diversion channel in the northern part of INL

A minor source of recharge is derived from the infiltration of rainfall and melted snowpack across INL. However, this direct infiltration of precipitation is considered to be a very small percentage of recharge that is distributed over INL. Those areas where direct infiltration may occur are not considered in this evaluation as aquifer recharge areas.

This criterion was not included in previous siting studies but is considered here because of the importance of aquifer protection. As described previously, protection of the SRPA from migration of radionuclides is an important consideration when siting a LLW disposal facility. If the containment structures of a facility located in a recharge zone were to fail, contaminants could be mobilized and could migrate to the aquifer. Thus, locations further from known SRPA recharge areas are preferable to closer locations. Based on the importance of aquifer protection, this criterion is considered to be appropriate.

The criterion of avoiding recharge is part of an overarching objective of avoiding sites where the groundwater table (perched or regional) may rise to within $29 \mathrm{ft}$ of ground surface or where surface water ponding or flooding could inundate a disposal site within the post-closure performance assessment period, so that wastes will be disposed under dry conditions.

\section{B-3.2.3 [31] Avoid Areas of Surface Water Flooding/Ponding}

This criterion was included in one of the previous siting studies and was recommended in the "Must" screening (Section B-2.2.4) for further consideration as a "Want" criterion. It is also an NRC performance objective (10 CFR 61.50(5)) that states that the disposal site must be "generally well drained and free of areas of flooding or frequent ponding..." At INL, rainfall on local snowpack and subsequent rapid snowmelt, when coupled with the low topographic relief, commonly results in local ponding and flooding that could compromise the performance of a LLW disposal facility. Sustained ponding and flooding can also result in conditions conducive to development of flow through the vadose zone. Generally speaking, a location with elevated topography and good surface-water drainage is preferable to a location with subdued topography and poor surface-water drainage. Based on the importance of avoiding ponding and flooding, this criterion is determined to be appropriate for use in the "Want" evaluation category.

The criterion of avoiding areas of surface water flooding or ponding is part of an overarching objective of avoiding sites where the groundwater table (perched or regional) may rise to within $29 \mathrm{ft}$ of ground surface or where surface water ponding or flooding could inundate a disposal site within the post-closure performance assessment period, so that wastes will be disposed under dry conditions.

\section{B-3.2.4 [32] Avoid Perched Water}

This criterion was included in one of the previous siting studies. It is not identified in DOE orders or regulations but is a component of a performance assessment. The site should be located in an area away from known perched water and in an area where hydrologic conditions and subsurface stratigraphy have little potential for development of perched water bodies. At INL, perched water is most likely to occur beneath wastewater infiltration or percolation ponds, beneath major waterways, and under the 
spreading area diversions near the RWMC. The presence of perched water near a permanent disposal facility indicates an active groundwater flow system through the vadose zone that can enhance the lateral and downward migration of contaminants in the subsurface. Sites located in areas with no perched water are desirable because groundwater flow in the vadose zone is minimized. Sites overlying perched water may be vulnerable to accelerated contaminant transport through vadose zone flow. For these reasons, this criterion is appropriate for use in the "Want" category.

\section{B-3.2.5 [33] Avoid Wellhead Protection Areas}

This criterion was not addressed in previous siting studies nor is it identified in DOE orders or in regulations. However, a voluntary wellhead protection program was recommended by the Idaho Department of Environmental Quality and subsequent to that recommendation, INL established a well-defined wellhead protection program with clearly delineated protection areas (Sehlke 2003). These protection areas were defined to include those areas located hydraulically upgradient from facility production wells. The protection areas were zoned to include areas immediately adjacent to wells where short groundwater travel times would preclude mitigation and areas further upgradient where travel times would permit mitigation. It is not a requirement that a new LLW disposal facility be located outside a wellhead protection area but it is considered useful information for the siting process and consequently is retained for use in the "Want" category.

\section{B-3.2.6 [34] Maximize Ground Water Transmissivity}

This criterion was included in one of the previous siting studies; however, it is not identified in DOE orders or in regulations. Locating areas of maximum aquifer transmissivity is a criterion designed to evaluate availability of water. The purpose of the criteria in the NPR study was to establish a location with easy access to large quantities of water to support operations. The relative location of "Utilities" (see Criterion \#39) included evaluation of the availability of the minimal water requirement for the disposal facility. Consequently, this criterion was considered but not used in the evaluation.

\section{B-3.2.7 [35] Minimize Depth of Wells for Water Supply}

This criterion was included in one of the previous siting studies; however, it is not identified in DOE orders or in regulations. As in Criterion \#34 above, the purpose of the criterion is to establish a location with easy access to large quantities of water for operations. The relative location of "Utilities" (see Criterion \#39) included evaluation of the availability of the minimal water requirement for the disposal facility. In addition, this criterion is incompatible with the requirements for a remote handled LLW disposal facility where greater depth to groundwater would be preferable. Consequently, this criterion was considered but not used in the evaluation.

\section{B-3.2.8 [36] Not Directly Above Aquifer}

Almost all of INL overlies the SRPA with the exception of Howe Point, a ridge of Paleozoic sedimentary rocks that extends a short distance onto INL east of Howe. This ridge is in proximity to the only known capable fault in the area and was disqualified as a potential site in the "Must" screening for Criterion \#1. For the remainder of INL, the aquifer occurs below a thick vadose zone ranging from $200 \mathrm{ft}$ to more than $900 \mathrm{ft}$ thick. Since the aquifer underlies almost the entire INL and would not provide a distinguishing characteristic between sites, this criterion was considered but not used. 


\section{B-3.3 Land Use}

In accordance with DOE Policy 430.1, "Land and Facility Use Planning," all land for which DOE is responsible will be managed as a valuable national resource. DOE land use planning integrates mission, economic, ecologic, social, and cultural factors in a comprehensive plan for each site that will guide land use decisions (DOE 1996). Legacy waste site management (i.e., long-term stewardship) is a core component of land-use planning, particularly relevant and important to siting a LLW disposal facility.

For these reasons, criteria relating to land use were carefully screened and selected and are shown in Table B-4. The criteria identified in the table provide a means of ranking candidate sites within the broad subject area of "Land Use." The left-hand column identifies criteria used in previous studies, the middle column identifies the criteria screened for use in this evaluation, and the right-hand column indicates criteria that were retained for use in this evaluation and those that were considered but not used.

Table B-4. Comparison of land use subject area "Want" criteria considered by previous INL siting studies with those identified for use in this siting study.

\begin{tabular}{|c|c|c|}
\hline $\begin{array}{l}\text { "Want" Criteria Identified from } \\
\text { Previous Siting Evaluations }\end{array}$ & $\begin{array}{c}\text { "Want" Criteria Considered for Remote-Handled } \\
\text { LLW Disposal Facility Evaluation }\end{array}$ & \\
\hline Locate in accordance with projected land use plans & 37. Locate within core infrastructure area & $\checkmark$ \\
\hline $\begin{array}{l}\text { Locate in areas controlled by U.S. Department of } \\
\text { Energy, Idaho Operations Office (DOE-ID) }\end{array}$ & Captured in \#37 & \\
\hline $\begin{array}{l}\text { Avoid areas selected for siting other proposed INL } \\
\text { projects }\end{array}$ & Captured in $\# 37$ & \\
\hline Not considered previously & 38. Avoid the explosives test area & $\checkmark$ \\
\hline Locate near existing infrastructure & 39. Locate near utilities and transportation & $\checkmark$ \\
\hline Minimize transportation issues & Captured in $\# 39$ & \\
\hline Locate in an area conducive to future expansion & $\begin{array}{l}40 \text {. Avoid industrial and institutionally controlled } \\
\text { areas }\end{array}$ & $\checkmark$ \\
\hline Avoid unexploded ordnance (UXO) areas & 41. Avoid Unexploded Ordnance areas & • \\
\hline $\begin{array}{l}\text { Minimize adverse interactions with existing } \\
\text { facilities }\end{array}$ & $\begin{array}{l}\text { 42. Minimize adverse interactions with existing } \\
\text { facilities }\end{array}$ & $\bullet$ \\
\hline Maximize distance from public highways & 43. Maximize distance from public highways & • \\
\hline Maximize distance from Site boundaries & 44. Maximize distance from Site boundaries & $\bullet$ \\
\hline Below US Highway 20/26 (or other public road) & 45. Avoid location south of US Highway $20 / 26$ & • \\
\hline Not considered previously & $\begin{array}{l}\text { 46. Minimize distance from waste generator to } \\
\text { facility }\end{array}$ & • \\
\hline
\end{tabular}

The sections that follow provide a discussion of each criterion in the context of siting an onsite remote-handled LLW disposal facility and indicate whether the criterion is retained or considered but not used for use in this siting evaluation. 


\section{B-3.3.1 [37] Locate Within Core Infrastructure Area}

The INL Comprehensive Land Use and Stewardship Report (Kostelnik 2005) implements DOE Policy 430.1, "Land and Facility Use Planning." The report integrates mission, economic, ecologic, social, and cultural factors in a comprehensive plan to guide growth and development of INL. The report is a central reference for siting any facility within INL. One aspect of land use planning considers the evolution of existing facilities and the addition of new facilities. Many existing facilities are being or are scheduled for decommissioning and the INL mission will continue to identify new facilities. Over the next 30 years, cleanup activities at each WAG will be completed and the sites will be under the INL Long-Term Stewardship Program. There may be portions of an individual WAG suitable for location of a LLW disposal facility. For this reason, it is reasonable to retain evaluation of FFA/CO sites to allow gradational evaluation of each WAG. The Land Use and Stewardship Report (Kostelnik 2005) identifies a 30 -year land use scenario that defines a "core infrastructure" area. Siting a facility in this area ensures it is consistent with overall land use planning.

This criterion was included in all of the previous siting studies either verbatim or expressed as several different criteria with slightly differing focus. It was reviewed in Section B-2.2.5 as a "Must" criterion with a recommendation that it be considered further in the "Want" category. DOE Orders 435.1 and 420.1B focus on safety, physical, and natural phenomena characteristics rather than the more general concept of land use. However, meeting the INL mission is intimately connected to current and future land use so this becomes an important part of any facility siting evaluation. For the purpose of identifying candidate sites for an onsite remote-handled LLW disposal facility, focusing on the 30-year scenario of the land use plan provides an excellent basis for relative scoring. The core infrastructure area identified in that scenario allows comparison of a number of specific land use parameters within one criterion. The four land use parameters that may be evaluated together include (1) areas controlled by DOE, (2) areas conducive to future expansion, (3) areas set aside for public use, and (4) areas set aside for protection of wildlife or ecosystems. A brief discussion of each of the four land use areas contributing to the core infrastructure concept is given below:

1. Areas controlled by DOE-ID. This specific criterion was included in two of the previous siting studies. By definition, any site located within the boundary of INL is in an area controlled by DOE. However, this criterion is considered relevant because the "core infrastructure" area is an area already accepted by DOE for future development to meet DOE missions.

2. Areas conducive to future expansion. This criterion was included in one of the previous siting studies. The purpose of the criterion was to ensure that sufficient space (surface and subsurface) would be available for the predicted volume of waste to be disposed at the facility. The projected volumes of remote-handled LLW are reasonable and provide a sufficient basis to determine a conservative area for the facility. Ensuring that the required area is within the "core infrastructure" area eliminates conflicts with land use plans outside the area.

3. Areas set aside for public use. Hunting and grazing are limited public use activities that are allowed on INL. Specifically, limited hunting for elk and antelope is allowed in some areas along the perimeter of INL and is administered in accordance with a memorandum of understanding with the Idaho Department of Fish and Game. In addition, the Bureau of Land Management (BLM) administers approximately 340,000 acres of grazing leases on INL. Ensuring that the facility is located within the "core infrastructure" area eliminates conflicts with public use of land outside the area.

4. Areas set aside for protection of wildlife or ecosystems. The Sagebrush-Steppe Ecosystem Reserve comprises 72,263 acres of critically endangered ecosystem, which requires special 
management obligations, including wildfire suppression, livestock grazing, road management, weed control, and protection of cultural resources. Ensuring that the facility is located within the "core infrastructure" area eliminates conflicts with the goals of the Sagebrush-Steppe Ecosystem Reserve. Due to the importance of preserving the Sagebrush-Steppe Ecosystem Reserve, this area is specifically addressed in Criterion \#47.

Thus, locating the site within the core infrastructure area and incorporating evaluation of the above points ensures consistency with INL future land-use plans and avoids areas that have been identified for future development or set aside for other purposes. A criterion addressing land use is an appropriate criterion for this remote-handled LLW disposal facility evaluation and it is retained in the "Want" category.

\section{B-3.3.2 [38] Avoid the Explosives Test Area}

This criterion was not included in previous siting studies but is considered here due to the importance of conforming to current and future INL land-use plans and the safety considerations associated with testing explosives. An environmental assessment has been prepared for the construction of a new National Security Test Range at a centralized location on INL (DOE 2007). Testing would be conducted to analyze the effects of explosives, munitions, and similar items on security systems, vehicles, structures, and other materials. However, testing would occur intermittently on a planned basis and disposal activities could be avoided during testing. Avoiding this test range is preferable, though not required, and the criterion is retained for use in the "Want" category.

\section{B-3.3.3 [39] Locate Near Utilities and Transportation}

This criterion was included in two of the previous siting studies and it was reviewed in Section B-2.2.6 as a "Must" criterion with a recommendation that it be considered further in the "Want" category. Infrastructure considered includes haul routes, emergency services, and utilities (power and water). Haul routes are an obviously important consideration for siting a LLW disposal facility and a site on or near a road to the waste generators is preferable. Emergency services are a consideration under DOE Guide 420.1-1 and DOE Guide 420.1-2. There are several facilities on INL where services such as fire control and medical/first aid are available and a preferable location would be relatively close to these facilities. Utility requirements for construction, operation, and maintenance of the facility are expected to be minimal and could be brought to the site (e.g., generators). If utilities are required but not available, they could be routed to a remote site with additional cost to the project. For these reasons, siting a location near transportation and utilities (particularly within 1 mile) is preferable but not required, so this criterion is recommended to be considered further in the "Want" category.

\section{B-3.3.4 [40] Avoid Industrial and Controlled Areas}

This criterion was not included in previous siting studies, but is considered here due to the importance of conforming to current and future INL facility operations. Industrial areas include the footprint of existing INL facilities, and institutionally controlled areas are primarily those designated as WAGs. There are 10 WAGs on INL, as defined in the FFA/CO (EPA et al. 1991). A WAG is an area that has undergone, or is undergoing, certain CERCLA remediation activities dependent on the nature and extent of contamination and administered in accordance with a Record of Decision (ROD) for the particular WAG. WAGs 1 through 9 are specific to certain contaminated INL facilities and the FFA/CO specifies the surface boundaries of these WAGs. WAG 10 encompasses all areas that fall outside of the other WAGs. Hazards associated with WAG 10 include potential UXO and associated explosive contaminants remaining from munitions testing activities. The hazard area is extensive and encompasses areas beyond INL boundaries that may have been impacted by INL activities. WAGs will be 
decommissioned over the next 30 years, but in terms of facility siting in the next 3 to 5 years, it is appropriate to retain this criterion in the "Want" category.

\section{B-3.3.5 [41] Avoid Unexploded Ordnance Areas}

This criterion was included in one of the previous siting studies. The INL has a history of ordnance use in support of military activities. From 1943 to 1945, a significant amount of U.S. Navy artillery was fired across various portions of the site. This testing resulted in the deposition of large numbers of both exploded ordnance and UXO in various regions of the site. From 1968 to 1970, the U.S. Navy again test fired battleship guns from an area near the original Central Facilities Area firing site. While avoiding UXO is desirable and was included as a "Want" criterion in previous siting studies, removal of UXO from an ordnance area is a required activity before any groundbreaking would occur. Consequently, avoiding UXO was not considered as a distinguishing criterion and was considered but not used in this siting evaluation process.

\section{B-3.3.6 [42] Minimize Adverse Interactions with Existing Facilities}

This criterion was included in one of the previous siting studies. It is also an NRC performance objective, which states that the disposal site "must not be located where nearby facilities or activities could adversely impact the ability of the site to meet performance objectives..." (10 CFR 61.50(11)). The location of a LLW disposal facility must consider potential impacts with other INL facilities or areas (i.e., reactors, processing facilities, or WAGs). Most importantly, an analysis will be conducted to determine any cumulative effects as a part of the NEPA process and as a part of a safety analysis. Consequently, an analysis of facility interactions was not considered as an appropriate criterion at the siting evaluation stage, so it was not used for this siting study.

\section{B-3.3.7 [43] Maximize Distance from Public Highways}

This criterion was included in one of the previous siting studies. The purpose of the criteria was improved security for the NPR. Other perceived benefits could include protection of the public from airborne emissions and avoiding a potential "eyesore." Security issues for a LLW disposal facility are minimal and will be controlled by engineered components such as a fence and alarm system. Protection of the public from airborne emissions is considered by other criteria. Finally, the onsite remote-handled LLW disposal facility would be constructed below grade and would have a low visibility profile from a nearby road. This criterion was considered but not used in the "Want" category.

\section{B-3.3.8 [44] Maximize Distance from Site Boundaries}

This criterion was included in one of the previous siting studies. The purpose of the criteria was to minimize the impacts associated with evacuation of nearby towns and farms in the event of a nuclear reactor emergency. This scenario is not relevant to a remote-handled LLW disposal facility and there are several other criteria that evaluate locations near the site boundary, particularly Criterion \#37

(Section B-3.3.1). Wherever the facility is located, engineered and institutional controls will be in place to prevent public intrusion. This criterion was considered but not used in the "Want" category.

\section{B-3.3.9 [45] Avoid Location South of US Highway 20/26}

This criterion was included in one of the previous siting studies. Its purpose was to minimize or eliminate risk to the public from shipping waste on or across a public highway. A transportation analysis will be conducted to determine any impact to the public as a part of the NEPA process and as a part of a 
safety analysis. Consequently, an analysis of transportation on public roads is not required at the siting evaluation stage and was considered but not used for this Siting Evaluation Report.

\section{B-3.3.10[46] Minimize Distance from Waste Generator to Facility}

This criterion was not included in any of the previous siting studies but is considered here because waste transportation cost and risk can be a factor when siting a LLW disposal facility. However, the projected volume of remote-handled LLW to be shipped for disposal is relatively small and is centrally located within the core infrastructure area. Consequently, an analysis of distance from waste generators was considered but not used for this Siting Study Report.

\section{B-3.4 Natural Resource Management}

The INL is a designated national environmental research park, functioning as a field laboratory set aside for ecological research and evaluation of the environmental impacts from nuclear energy development. Ecological preservation and natural resource management are core components of environmental stewardship, defined as the responsible management of INL lands, resources, and facilities (Kostelnik 2005).

The criteria identified in Table B-5 provide a means of ranking candidate sites within the broad subject area of "Natural Resource Management." The left-hand column identifies criteria used in previous studies and the middle column identifies the criteria screened for use in this evaluation. The right-hand column indicates criteria that were retained for use in this evaluation and those that were considered but not used. The sections that follow provide a discussion of each criterion in the context of siting an onsite remote-handled LLW disposal facility and indicate whether the criterion is retained or considered but not used in this siting evaluation.

Table B-5. Comparison of natural resource subject area "Want" criteria considered by previous INL siting studies with those identified for use in this siting study.

\begin{tabular}{lll}
\hline $\begin{array}{l}\text { "Want" Criteria Identified } \\
\text { from Previous Siting Evaluations }\end{array}$ & $\begin{array}{l}\text { "Want" Criteria Considered for Remote-Handled } \\
\text { LLW Disposal Facility Evaluation }\end{array}$ \\
\hline Not considered previously & 47. Avoid the Sagebrush-Steppe Ecosystem Reserve & $\checkmark$ \\
Avoid vegetation transects & 48. Avoid vegetation transects & $\checkmark$ \\
Minimize impact to riparian areas & 49. Avoid ecologically sensitive habitat & \\
Minimize impact to ecologically sensitive areas & Captured in \#50 \\
Minimize environmental impact on biota & Captured in \#50 \\
Use previously disturbed areas & 50. Use previously disturbed areas \\
Minimize impacts to cultural resources & 51. Minimize impacts to cultural resources \\
Outside wind corridors of existing INL facilities & 52. Outside wind corridors of existing INL facilities \\
Minimize public air pollution impact & 53. Minimize public air pollution impact \\
$\checkmark=$ Criterion included in the Remote-Handled LLW Disposal Project facility siting evaluation. \\
$\qquad=$ Criterion considered but not used.
\end{tabular}




\section{B-3.4.1 [47] Avoid the Sagebrush-Steppe Ecosystem Reserve}

This criterion was not included in any of the previous siting studies and it is not identified in DOE orders or in regulations. The INL lies within the sagebrush-steppe region of North America. The sagebrush-steppe is a critically endangered ecosystem characterized by dry habitat dominated by various species of sagebrush and other shrubs, short grasses, and forbs. 72,263 acres of INL have been designated as the Sagebrush-Steppe Ecosystem Reserve, which require special management obligations, including wildfire suppression, livestock grazing, road management, weed control, and protection of cultural resources (BLM 2004). Due to the unique nature of the Sagebrush-Steppe Ecosystem Reserve and the importance of protecting its biodiversity, this criterion is appropriate for evaluating siting of the onsite remote-handled LLW disposal facility location.

\section{B-3.4.2 [48] Avoid Vegetation Transects}

This criterion was included in one of the previous siting studies. Two vegetation transects cross INL. Data from these transects have been collected for approximately 60 years to monitor long-term changes in vegetation at undisturbed settings. Due to the unique data provided by these transects, it is undesirable to locate a facility within the transect boundaries. Thus, this criterion is appropriate for consideration in the "Want" category for this evaluation.

\section{B-3.4.3 [49] Avoid Ecologically Sensitive Habitat}

This criterion was carried forward from the "Must" criteria evaluation which considered "Avoid Critical Habitats of Endangered Species." Given that there are no T\&E species present at INL and that there are several species currently being considered for listing (e.g., sage grouse, pygmy rabbit), a new criterion was created to allow evaluation of candidate sites based on potential impact to ecologically sensitive areas. Habitat surveys have been conducted at INL as part of the DOE ESER Program. In the absence of identified critical habitat, it is important that sensitive habitat be considered in the "Want" criteria category.

Included in this criterion are considerations to reduce impacts on riparian areas, ecologically sensitive areas, and habitats that are of importance to T\&E species, and species of special concern. While most riparian areas lie along the Big Lost River and Birch Creek, there may be other, smaller riparian areas on INL. Several areas on INL have been designated as ecologically sensitive areas for various reasons, including (1) the presence of sage grouse leks or raptor nesting sites, (2) the presence of one or more undisturbed, unique, or representative desert habitat types, and (3) ecological research areas such as revegetation study sites. A preferable site will avoid these areas. If the NEPA process identifies a preferred site on or near sensitive habitat (as defined), a natural resource survey will be conducted and mitigation actions (e.g., move site location) will be taken to minimize any effects. Due to the unique and varied flora and fauna present on INL and the status of INL as a National Environmental Research Park, protection of habitat is important. For these reasons, this criterion is appropriate for use in the "Want" category.

\section{B-3.4.4 [50] Use Previously Disturbed Areas}

This criterion was included in one of the previous siting studies, though it is not identified in DOE orders or in regulations. Reuse of previously disturbed areas reflects responsible use of INL resources and helps preserve biodiversity by minimizing habitat fragmentation. This concept is reflected in INL land-use planning, which promotes new developments in the core infrastructure area (Kostelnik 2005). However, this concept is considered in Criterion \#37 (Section B-3.3.1) and would be duplicated here. Thus, this criterion was considered but not used for this Siting Study Report. 


\section{B-3.4.5 [51] Minimize Impacts to Cultural Resources}

This criterion was included in one of the previous siting studies and is a requirement of several federal regulations (see Appendix A). Based on a number of site-specific intensive surveys conducted in the past, there are numerous cultural resources (prehistoric and historic) on INL and a predictive analysis suggests there are many that have not been documented (DOE-ID 2004). Certain habitat and/or physiographic regions have a higher likelihood of containing cultural resources than other areas (e.g., water and food sources, protected areas such as caves and buttes). Depending on location, there is the likelihood that archaeological material may be uncovered during construction of a LLW disposal facility. It is a requirement that impacts be mitigated by appropriate institutional and engineering controls during site preparation and construction. However, evaluation of a site for cultural resources is part of the NEPA process and is generally not applied in the siting evaluation. Thus, this criterion was considered but not used in the "Want" category for this Siting Study Report.

\section{B-3.4.6 [52] Outside Wind Corridors of Existing INL Facilities}

This criterion was included in one of the previous siting studies for a high-level waste treatment facility where airborne emission was a significant consideration. The objective of the criterion is to protect workers at existing INL facilities that are downwind of a proposed facility. However, the identified waste forms for the remote-handled LLW disposal facility are not expected to release airborne contaminants, and the cover can be engineered to minimize or attenuate airborne releases. Also, this issue would be addressed in the cumulative effects analysis conducted as part of the NEPA process or as part of composite analysis during the safety analysis. Consequently, this criterion was considered but not used in the "Want" category.

\section{B-3.4.7 [53] Minimize Public Air Pollution Impact}

This criterion was also included in one of the previous siting studies for a high-level waste treatment facility where airborne emission was a significant consideration. Any radionuclide emissions from this facility would be regulated under the National Emission Standards for Hazardous Air Pollutants. However, the identified waste forms for the Remote-Handled LLW Disposal Facility are not expected to release airborne contaminants, and the cover can be engineered to minimize or attenuate airborne releases. Air pollution caused by fugitive dust during construction of the facility is normally abated by use of best management practices such as frequent watering. Consequently, this criterion was considered but not used in the "Want" category. Also, this criterion is addressed in a facility impacts assessment conducted as part of the NEPA process or as part of a performance assessment during the safety analysis.

\section{B-3.5 Recommended "Want" Criteria}

The result of the screening process documented above is selection of 21 "Want" criteria that are used to evaluate the candidate sites, produce a site-by-site score, and determine a relative ranking that identifies those locations best suited for siting a remote-handled LLW disposal facility. The 21 recommended "Want" criteria for siting an onsite remote-handled LLW disposal facility are as follows:

1. Maximize surficial sediment thickness (Section B-3.1.1)

2. Maximize continuity of sediment thickness (Section B-3.1.2)

3. Enhance retardation to minimize migration (Section B-3.1.3)

4. Maximize continuity of interbeds (Section B-3.1.4) 
5. Minimize potential earthquake impact (Section B-3.1.5)

6. Maximize distance from volcanic hazard zone (Section B-3.1.6)

7. Locate where discriminatory monitoring can be achieved (Section B-3.1.7)

8. Availability of geotechnical data (Section B-3.1.8)

9. Availability of characterization data (Section B-3.1.9)

10. Minimize proximity to floodplains (Section B-3.2.1)

11. Avoid aquifer recharge areas (Section B-3.2.2)

12. Avoid areas of surface water flooding or ponding (Section B-3.2.3)

13. Avoid areas overlying perched water (Section B-3.2.4)

14. Avoid wellhead protection areas (Section B-3.2.5)

15. Locate within core infrastructure area (Section B-3.3.1)

16. Avoid the explosives test area (Section B-3.3.2)

17. Locate near transportation and utilities (Section B-3.3.3)

18. Avoid industrial and institutionally controlled areas (Section B-3.3.4)

19. Avoid the Sagebrush-Steppe Ecosystem Reserve (Section B-3.4.1)

20. Avoid vegetation transects (Section B-3.4.2)

21. Avoid ecologically sensitive habitat (Section B-3.4.3).

The 4 "Must" and 21 "Want" criteria identified in this Appendix are carried forward to the Siting Evaluation Report for determination of the candidate sites to be considered in the NEPA process. The actual evaluation of criteria is presented in Section 3 of the Siting Evaluation Report and the detailed determination of site-by-site, criterion-by-criterion scores is summarized in Appendix C.

\section{B-4. REFERENCES}

10 CFR 61, 2002, Title 10, “Energy," Part 61, "Licensing Requirements for Land Disposal of Radioactive Waste," Code of Federal Regulations, Office of the Federal Register.

10 CFR 61.50, 2002, Title 10, "Energy," Part 61, "Licensing Requirements for Land Disposal of Radioactive Waste," Section 61.50, "Disposal Site Suitability Requirements for Land Disposal," Code of Federal Regulations, Office of the Federal Register.

10 CFR 100, 2002, Title 10, "Energy," Part 100, "Reactor Site Criteria," Appendix A, "Seismic and Geologic Siting Criteria for Nuclear Power Plants," Code of Federal Regulations, Office of the Federal Register. 
10 CFR 1022, 2002, Title 10, "Energy," Part 1022, "Compliance with Floodplain and Wetland Environmental Review Requirements," Code of Federal Regulations, Office of the Federal Register.

BLM, 2004, INEEL Sagebrush Steppe Ecosystem Reserve Final Management Plan, EA-ID-07402-067. U.S. Bureau of Land Management, Idaho Falls, Idaho.

Crone, A.J. and K.M. Haller, 1991, "Segmentation and Coseismic Behavior of Basin-and-Range Normal Faults: Examples from East-Central Idaho and Southwestern Montana, U.S.A.," Journal of Structural Geology, v.13, p.151-164.

DOE, 1996, Land and Facility Use Planning, DOE Policy 430.1, U.S. Department of Energy, Washington D.C.

DOE, 2007, Final Environmental Assessment for the National Security Test Range, DOE/EA-1557, U.S. Department of Energy, Washington D.C.

DOE Guide 420.1-1, Nonreactor Nuclear Safety Design Criteria and Explosives Safety Criteria Guide for Use with DOE O 420.1, Facility Safety, U.S. Department of Energy, March 28, 2000.

DOE Guide 420.1-2, Guide for the Mitigation of Natural Phenomena Hazards for DOE Nuclear Facilities and Nonnuclear Facilities, U.S. Department of Energy, March 28, 2000.

DOE Guide 435.1-1, Implementation Guide for Use with DOE M 435.1-1, U.S. Department of Energy, July $9,1999$.

DOE Manual 435.1-1, Radioactive Waste Management Manual, U.S. Department of Energy, June 19, 2001.

DOE Order 420.1B, Facility Safety, U.S. Department of Energy, December 22, 2005.

DOE Order 435.1, Radioactive Waste Management, U.S. Department of Energy, August 28, 2001.

DOE Order 5480.23, 1994, Safety Analysis Reports, Change 1, U.S. Department of Energy, March 10, 1994.

DOE-ID, 2004, Idaho National Engineering and Environmental Laboratory Cultural Resource Management Plan, DOE/ID-10997, Revision 0, U.S. Department of Energy Idaho Operations Office, Idaho Falls, Idaho.

DOE-STD-1020-2002, Natural Phenomena Hazards Design and Evaluation Criteria for Department of Energy Facilities, U.S. Department of Energy, January 2002.

DOE-STD-1021-93, Natural Phenomena Hazards Performance Categorization Guidelines for Structures, Systems, and Components, U.S. Department of Energy, April 2002.

DOE-STD-1022-94, Natural Phenomena Hazards Site Characterization Criteria, U.S. Department of Energy, March 1994, Reaffirmed with Errata April 2002.

EPA, State of Idaho, IDHW, and DOE, 1991, Idaho National Engineering Laboratory Federal Facility Agreement and Consent Order, Administrative Docket Number 1088-06-120, U.S.

Environmental Protection Agency Region 10, the State of Idaho, Idaho Department of Health and Welfare, and the U.S. Department of Energy. Washington, D.C. 
Hackett, W.R. J.A. Tullis, R.P. Smith, S.J. Miller, T.V. Dechert, P.A. McDaniel, and A.L. Falen, 1994, Geologic Processes in the RWMC, Idaho National Laboratory: Implications for Long Term Stability and Soil Erosion at the Radioactive Waste Management Complex, EGG-WM-111430, September 1994.

Hackett, W.R., R.P. Smith, and S. Khericha, 2002, "Volcanic Hazards of the Idaho National Engineering and Environmental Laboratory, Southeast Idaho, in Tectonic and Magmatic Evolution of the Snake River Plain Volcanic Province," Idaho Geological Survey Bulletin 30, edited by B. Bonnichsen, C.M. White, and M. McCurry.

IBC, 2000, International Building Code, 1st ed., ISBM 1892395258, International Code Council, Falls Church, Virginia.

INL, 2007, "Draft Conceptual Design Report for Remote-Handled Low-Level Waste Disposal Facility," INL/EXT-07-12901, Idaho National Laboratory, Idaho Falls, Idaho.

Kostelnik, K.M., 2005, Idaho National Laboratory Comprehensive Land Use and Environmental Stewardship Report, INL/EXT-05-00726, Idaho National Laboratory, Idaho Falls, Idaho.

Ostenaa, D.A., and D.R.H. O’Connell, 2005. Big Lost River Flood Hazard Study Idaho National Laboratory, Idaho - Summary Document. U.S. Department of the Interior, Bureau of Reclamation, Technical Service Center, Seismotechtonics and Geophysics Group, Denver, CO. Report 2005-2.

Sehlke, G., 2003, The Idaho National Engineering and Environmental Laboratory Source Water Assessment, INEEL/EXT-02-01474, Idaho National Engineering and Environmental Laboratory, Idaho Falls, Idaho.

Smith, R.P., S.M. Jackson, and W.R. Hackett, 1996, "Paleoseismology and Seismic Hazards Evaluations in Extensional Volcanic Terrains," Journal of Geophysical Research, v. 101, no. B3, p.62776292.

T\&FR-483, "Draft Technical and Functional Requirements Remote-Handled Low-Level Waste Disposal Facility," TFR-483, Draft Revision E, July 24, 2007, Idaho National Laboratory, Idaho Falls, Idaho, Battelle Energy Alliance, LLC.

USGS, 2006, Quaternary Fault and Fold Database for the United States, Accessed July 6, 2007 from U.S. Geological Survey web site: http//earthquakes.usgs.gov/regional/qfaults/, United States Geological Survey. 


\section{Appendix C}

\section{Application of Site Evaluation Criteria}


C-2 


\section{CONTENTS}

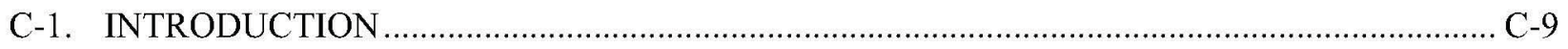

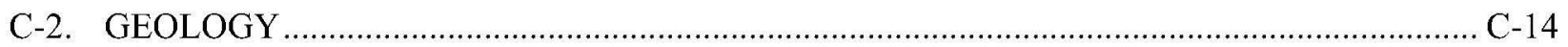

C-2.1 [18] Maximize Surficial Sediment Thickness ............................................................... C-14

C-2.2 [19] Maximize Sediment Thickness Continuity ……..................................................... C-17

C-2.3 [20] Maximize Retardation to Attenuate Migration ...................................................... C-18

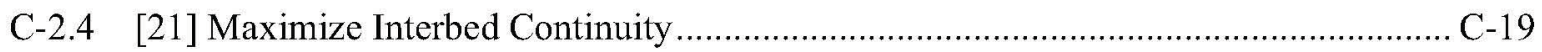

C-2.5 [22] Minimize Impact from Earthquakes .................................................................. C-20

C-2.6 [23] Maximize Distance from Volcanic Hazard Zones ............................................... C-23

C-2.7 [24] Locate to Facilitate Discriminatory Monitoring ................................................ C-25

C-2.8 [25] Availability of Geotechnical Data ................................................................. C-26

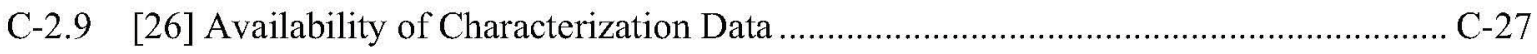

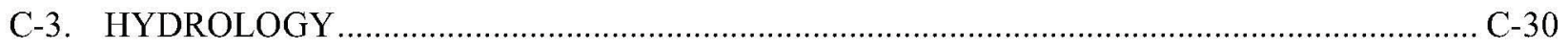

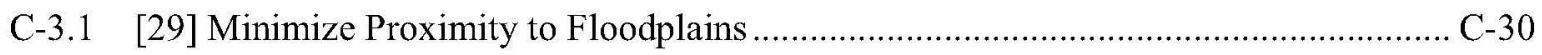

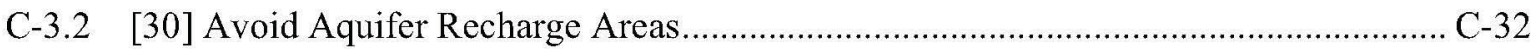

C-3.3 [31] Avoid Areas of Surface Water Flooding or Ponding ......................................... C-37

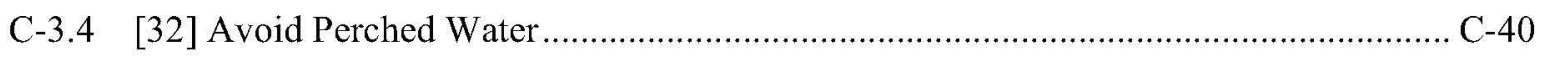

C-3.5 [33] Avoid Wellhead Protection Areas ....................................................................... C-41

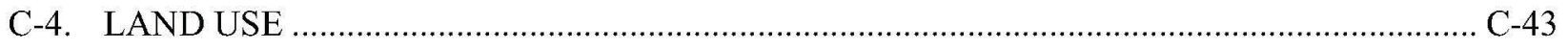

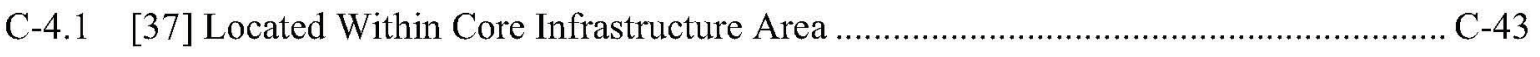

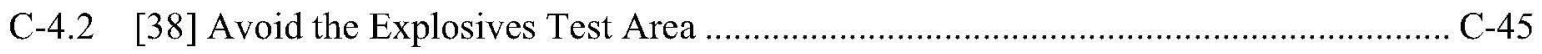

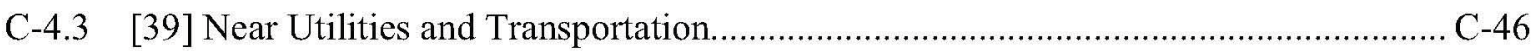

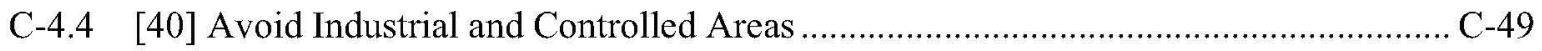

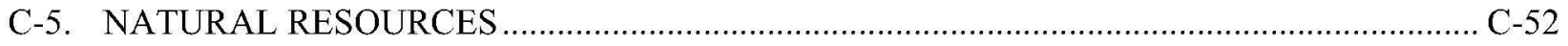

C-5.1 [47] Avoid the Sagebrush-Steppe Ecological Reserve ................................................. C-52

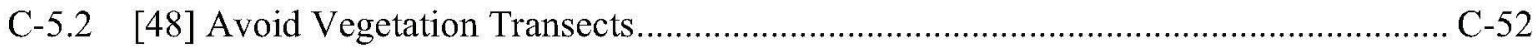


C-5.3 [49] Avoid Ecologically Sensitive Species and Habitat ............................................ C-55

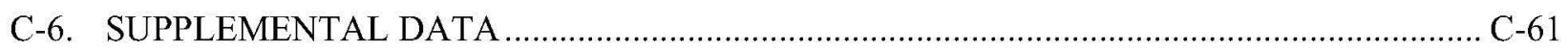

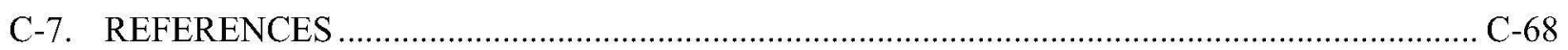

\section{FIGURES}

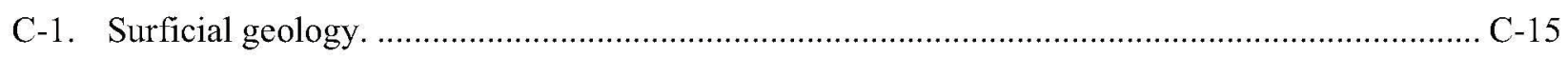

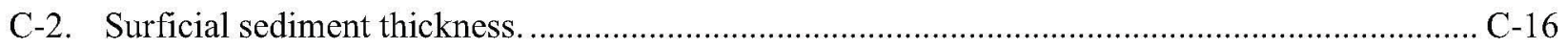

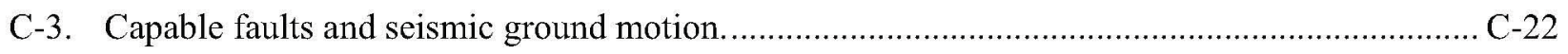

C-4. Zones of highest volcanic hazards) (areas within a distance of 5 mi of a volcanic vent younger than 400,000 years) and lower volcanic hazards (areas between 5 and $9 \mathrm{mi}$ of a volcanic vent younger than 400,000 years) ................................................................... C-24

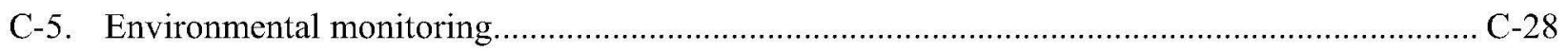

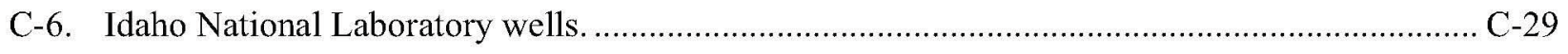

C-7. 100-year floodplain and extent of pluvial Lake Terreton within the INL boundaries................. C-33

C-8. 100-year floodplain around the Idaho Nuclear Technology and Engineering Center................ C-34

C-9. 500-year floodplain around the Idaho Nuclear Technology and Engineering Center................. C-35

C-10. Comparison of the estimated 500-, 1,000-, and 10,000-year floods........................................ C-36

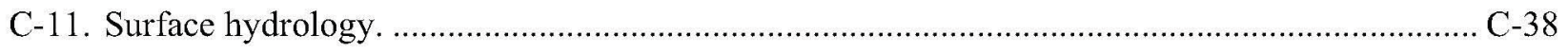

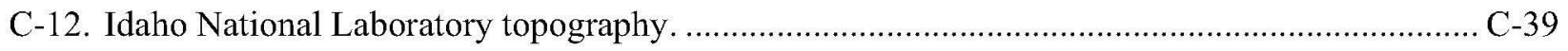

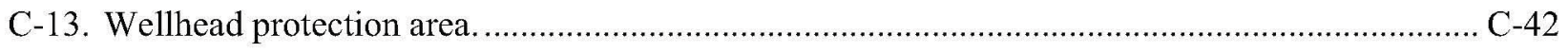

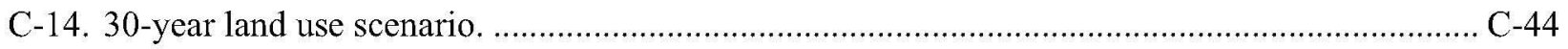

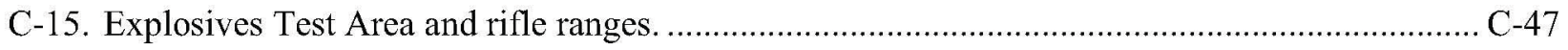

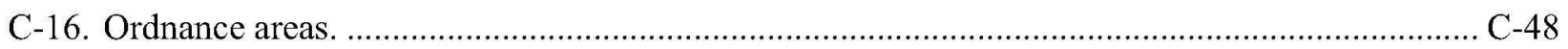

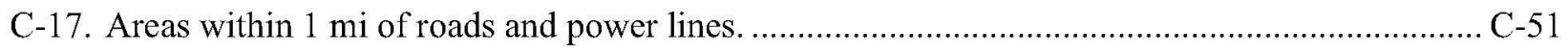

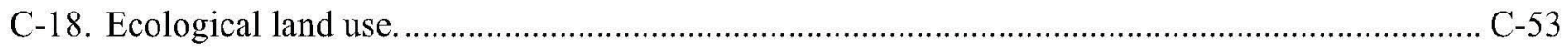

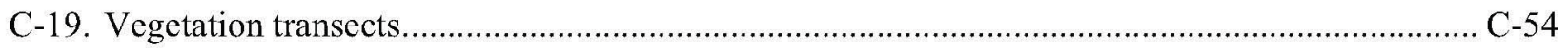

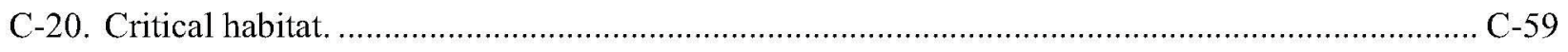

C-21. Idaho National Laboratory regional geology .........................................................................62 
C-22. Potentiometric surface of the Snake River Plain Aquifer in 1999 in the vicinity of the Idaho National Laboratory.

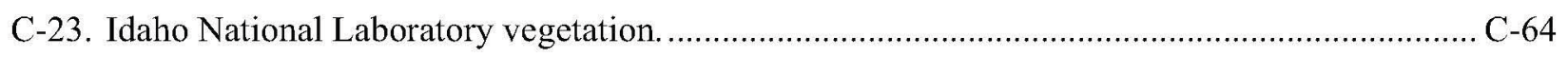

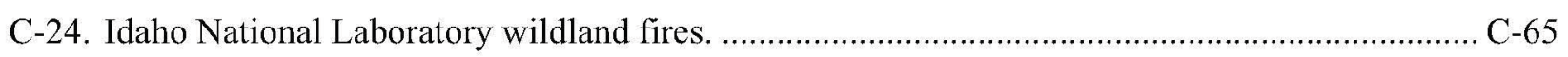

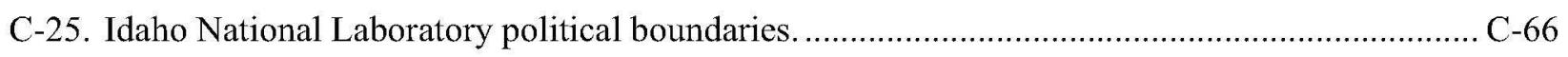

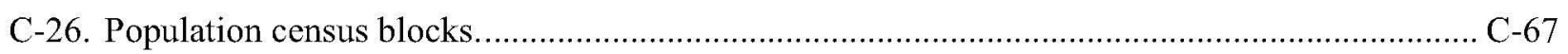

\section{TABLES}

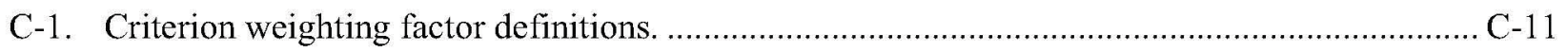

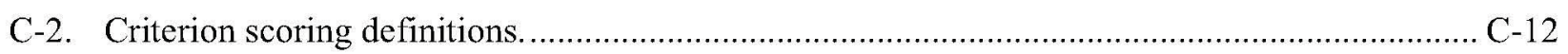

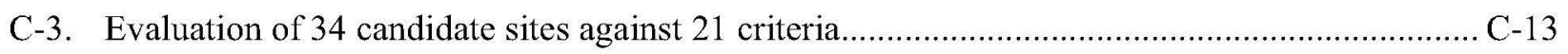

C-4. Surficial sediment thickness criterion score ....................................................................

C-5. Surficial sediment continuity criterion score.................................................................. C-18

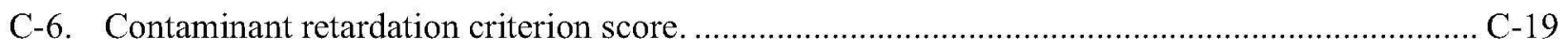

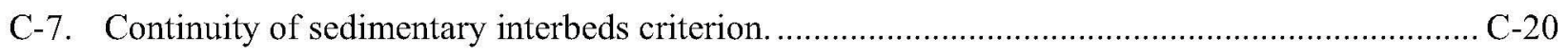

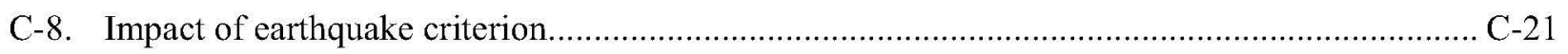

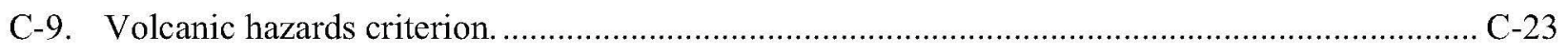

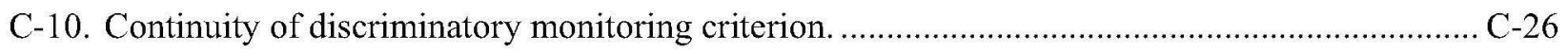

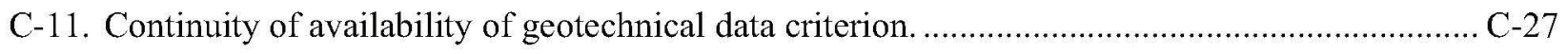

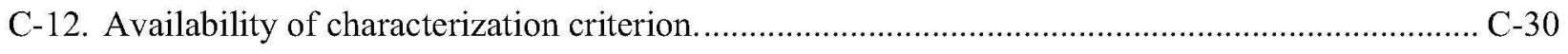

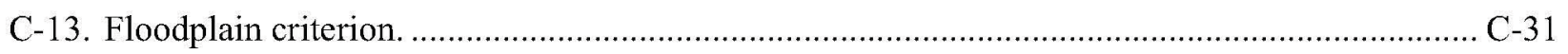

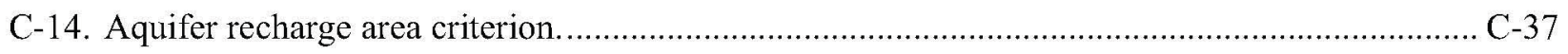

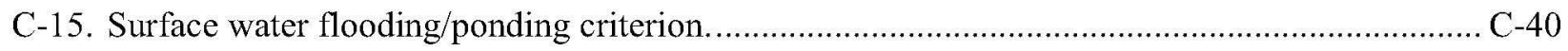

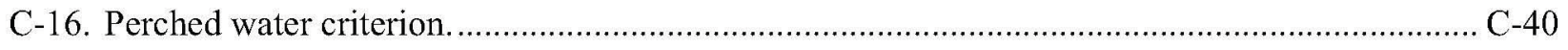

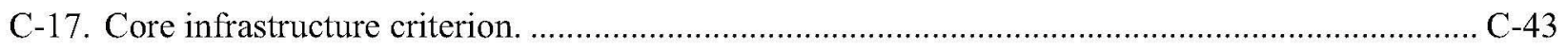

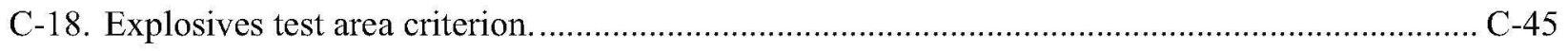

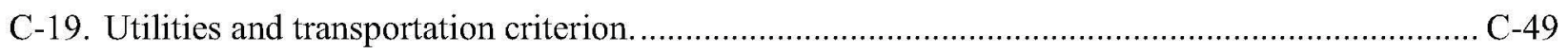

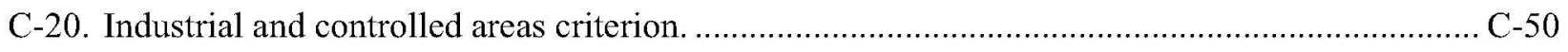


C-21. Sagebrush-Steppe Ecosystem Reserve criterion...................................................................... C-52

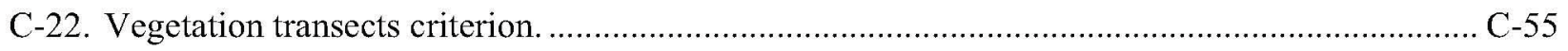

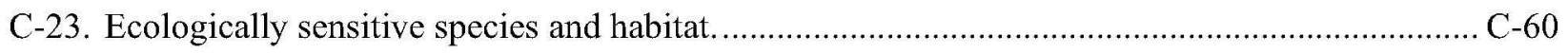




\section{ACRONYMS}

ARA Auxiliary Reactor Area

ATR Advanced Test Reactor

BLM Bureau of Land Management

CDC Conservation Data Center

CV coefficient of variation

ESER Environmental Surveillance, Education, and Research

ESRP Eastern Snake River Plain

INL Idaho National Laboratory

INTEC Idaho Nuclear Technology and Engineering Center

LLW low-level waste

MFC Materials and Fuels Complex

NPR New Production Reactor

NRF Naval Reactors Facility

PA Performance Assessment

PBF Power Burst Facility

RSWF Radioactive Scrap Waste Facility

RWMC Radioactive Waste Management Complex

SL-1 Stationary Low-Power Reactor 1

SRPA Snake River Plain Aquifer

TAN Test Area North

USGS United States Geological Survey

WAG Waste Area Group 
C-8 


\section{Appendix C \\ Application of Site Evaluation Criteria \\ C-1. INTRODUCTION}

Appendix $\mathrm{C}$ is the last of three appendices prepared to support the Remote-Handled Low-Level Waste (LLW) Disposal Project's onsite facility siting study. Appendix A provided a review of requirements, and Appendix B defined and evaluated 54 criteria, selecting 25 for use in this siting study report. The first four of the 25 criteria selected are "Must" criteria which, when applied to the 34 candidate sites, resulted in identification of 31 sites for evaluation against the "Want" criteria. A total of 21 "Want" criteria were selected for use in this evaluation. The criteria were divided into four subject area groups (geology, hydrology, land use, and natural resources) for easier review and scoring. The groups and corresponding criteria are as follows:

\section{Geology:}

1. Maximize surficial sediment thickness [18]

2. Maximize sediment thickness continuity [19]

3. Enhance retardation to minimize migration [20]

4. Maximize interbed continuity [21]

5. Minimize impact of earthquakes[22]

6. Maximize distance from volcanic hazard zones [23]

7. Locate to facilitate discriminatory monitoring [24]

8. Availability of geotechnical data [25]

9. Availability of characterization data [26].

\section{Hydrology:}

10. Minimize proximity to floodplains [29]

11. Avoid aquifer recharge areas [30]

12. Avoid areas of surface water flooding/ponding [31]

13. Avoid perched water [32]

14. Avoid wellhead protection areas [33]. 


\section{Land Use:}

15. Locate within core infrastructure area [37]

16. Avoid the explosives test area [38]

17. Locate near utilities and transportation [39]

18. Avoid industrial and controlled areas [40].

\section{Natural Resources:}

19. Avoid the Sagebrush-Steppe Ecosystem Reserve [47]

20. Avoid vegetation transects [48]

21. Avoid ecologically sensitive habitat [49].

For ease of reference, the 21 "Want" criteria are numbered 1 through 21 . The criteria definitions and additional background discussion are presented in Appendix B, where a separate numbering system was used to allow discrete separation of all 54 criteria screened for use in this evaluation. The number in square brackets following the criteria above provides a crosswalk to the criteria definitions found in Appendix B. The Appendix B table of contents also includes the same square bracket numbering system to facilitate crosswalk between the criteria evaluation in Appendix $\mathrm{C}$ to criteria definition in Appendix B.

Table C-1 summarizes "Want" criteria by weighting factor group and provides a rationale for assigning a numerical weight from 1 to 5 (1- "Very Low," 2 - "Low," 3 - "Medium," 4 = "High," and $5=$ "Very High"). Table C-2 lists each "Want" criterion by technical subject area, identifies the definition and rationale for each scoring factor ( 1 = "Low," 2 = "Medium," and 3 = "High"). Table C-3 summarizes the application of the evaluation process site-by-site, criterion-by-criterion. The weighting factors and scoring factors are designed such that the most suitable sites receive the highest scores. The remainder of Appendix $\mathrm{C}$ presents graphical representations of the data that support criterion evaluation and a brief discussion of how the scores were assigned. The evaluation process is subjective and is often based on professional judgment. However, where possible, semi-quantitative criteria were developed to guide the evaluation and scoring process. 
Table C-1. Criterion weighting factor definitions.

\begin{tabular}{|c|c|c|}
\hline Criterion & $\begin{array}{l}\text { Weighting } \\
\text { Factor }\end{array}$ & Weighting Factor Rationale \\
\hline \multicolumn{3}{|r|}{ (2) } \\
\hline Maximize Surficial Sediment Thickness & 5 & $\begin{array}{l}\text { Thick surficial sediments provide more design options. Coarser texture sediments facilitate drainage. Mitigation of the absence } \\
\text { of surficial sediment is technically impractical with a very high cost. }\end{array}$ \\
\hline Maximize Sediment Thickness Continuity & 5 & $\begin{array}{l}\text { High uncertainty and variability reduce design options and increase uncertainty in transport predictions. Mitigation of surficial } \\
\text { sediment thickness variability is technically impractical with a very high cost. }\end{array}$ \\
\hline $\begin{array}{l}\text { Maximize Retardation to Attenuate } \\
\text { Migration }\end{array}$ & 5 & $\begin{array}{l}\text { Thicker interbed sediments and fine grained materials retard migration, increase radioactive decay time, resulting in reduced } \\
\text { groundwater impacts. Altering in situ interbed thickness is technically impossible. }\end{array}$ \\
\hline Maximize Interbed Continuity & 5 & $\begin{array}{l}\text { Interbed continuity (low uncertainty and variability) lowers transport prediction uncertainty and increases retardation capacity, } \\
\text { lowering risk. Altering in situ interbed thickness variability is technically impossible. }\end{array}$ \\
\hline Minimize Proximity to Floodplains & 5 & $\begin{array}{l}\text { Location within a floodplain is very undesirable. Mitigation within floodplain is technically possible at significant cost. } \\
\text { Mitigation near floodplain possible at lower cost or by increasing distance. }\end{array}$ \\
\hline Avoid the Explosives Test Area & 5 & $\begin{array}{l}\text { Location in the Explosive Test Area exclusion zone is unallowable. Ensuring safety of employees/public is of highest } \\
\text { importance. }\end{array}$ \\
\hline \multicolumn{3}{|r|}{1} \\
\hline Located Within Core infrastructure Area & 4 & Location within the core infrastructure area is very desirable to be consistent with INL future land-use plans \\
\hline Locate Near Utilities and Transportation & 4 & $\begin{array}{l}\text { Location near existing transportation and utilities is desirable, may significantly reduce offsite impacts associated with providing } \\
\text { new support infrastructure. Development of new support infrastructure is feasible at significant cost. }\end{array}$ \\
\hline $\begin{array}{l}\text { Avoid Sagebrush-Steppe Ecosystem } \\
\text { Reserve }\end{array}$ & 4 & $\begin{array}{l}\text { Location within Sagebrush-Steppe Ecosystem Reserve is undesirable because it is one of the last large tracts of this habitat type } \\
\text { in southern Idaho and because of the importance of protecting its biodiversity (e.g., habitat for sage grouse and pygmy rabbits). }\end{array}$ \\
\hline Avoid Ecologically Sensitive Habitat & 4 & Location within ecologically sensitive habitat is undesirable. Mitigation is possible but may have significant cost. \\
\hline \multicolumn{3}{|r|}{ ( } \\
\hline Minimize Impact from Earthquakes & 3 & $\begin{array}{l}\text { Performance assessment for similar INL facilities suggests that seismic ground motion would have little effect on facility } \\
\text { performance. Technical mitigation possible by increasing distance from sources and through facility design. }\end{array}$ \\
\hline $\begin{array}{l}\text { Maximize Distance from Volcanic Hazard } \\
\text { Zones }\end{array}$ & 3 & $\begin{array}{l}\text { Location near volcanic hazard not desirable because of lava inundation risk and potentially adverse effects on waste from } \\
\text { increased temperature. Technical mitigation possible by increasing distance from sources and through facility design.. }\end{array}$ \\
\hline Availability of Characterization Data & 3 & $\begin{array}{l}\text { Characterization data are important to natural phenomena hazard and performance assessment. However, additional } \\
\text { characterization can be obtained at moderate cost. }\end{array}$ \\
\hline Avoid Aquifer Recharge Areas & 3 & $\begin{array}{l}\text { Location away from recharge areas is desirable. Technical mitigation is possible by increasing distance from recharge areas. At } \\
\text { the INL, recharge areas are limited to ephemeral streams and playas. }\end{array}$ \\
\hline Avoid Wellhead Protection Areas & 3 & $\begin{array}{l}\text { Protection of facility water supply is desirable. Technical mitigation is possible through development of external or new potable } \\
\text { water supplies at moderate cost. }\end{array}$ \\
\hline Avoid Vegetation Transects & 3 & Location within vegetation transect is not desirable. Mitigation (site relocation) is possible at moderate cost. \\
\hline \multicolumn{3}{|r|}{ (1) } \\
\hline $\begin{array}{l}\text { Locate to Facilitate Discriminatory } \\
\text { Monitoring }\end{array}$ & 2 & $\begin{array}{l}\text { Location near known contamination makes discriminatory monitoring more difficult. Mitigation is technically possible through } \\
\text { monitoring network design and sampling strategy at low additional cost. }\end{array}$ \\
\hline Availability of Geotechnical Data & 2 & $\begin{array}{l}\text { Geotechnical data supports design, construction and performance assessment. Geotechnical data can be collected during the } \\
\text { design/construction phases at low cost. }\end{array}$ \\
\hline $\begin{array}{l}\text { Avoid Areas of Surface Water } \\
\text { Flooding/Ponding }\end{array}$ & 2 & $\begin{array}{l}\text { Location in area prone to surface water ponding/flooding is undesirable; however, mitigation is technically possible during } \\
\text { design at low cost (e.g., moving site location to higher ground). Scoring factor addresses degree of adequate drainage. }\end{array}$ \\
\hline Avoid Perched Water & 2 & $\begin{array}{l}\text { Perched water may enhance migration; however, it dilutes concentration and allows early detection. Technical mitigation } \\
\text { possible by avoiding areas of perched water or installation of additional monitoring at low cost. }\end{array}$ \\
\hline \multicolumn{3}{|l|}{ Very Low } \\
\hline Avoid Industrial and Controlled Areas & 1 & Location inside an industrial area is undesirable; however, mitigation within a controlled area is possible at low cost. \\
\hline
\end{tabular}


Table C-2. Criterion scoring definitions.

\begin{tabular}{|c|c|c|c|}
\hline Criterion & 1 & $\begin{array}{c}\text { Score } \\
\mathbf{3}\end{array}$ & 5 \\
\hline \multicolumn{4}{|l|}{ GEOLOGY } \\
\hline Maximize Surficial Sediment Thickness & $\begin{array}{l}\text { Thin fluvial deposits, }<10 \mathrm{ft} \text {, or all lacustrine } \\
\text { deposits }\end{array}$ & Thicker fluvial deposits, 10 to $20 \mathrm{ft}$ & Fluvial deposits exceeding $20 \mathrm{ft}$ \\
\hline Maximize Sediment Thickness Continuity & Coefficient of variation $>0.60$ & Coefficient of variation between 0.30 and 0.60 & Coefficient of variation $<0.30$ \\
\hline Maximize Retardation to Attenuate Migration & $\begin{array}{l}\text { Cumulative fine grain interbed thickness less } \\
\text { than } 10 \mathrm{ft}\end{array}$ & $\begin{array}{l}\text { Cumulative fine grain interbed thickness between } \\
10 \text { and } 20 \mathrm{ft}\end{array}$ & $\begin{array}{l}\text { Cumulative fine grain interbed thickness greater } \\
\text { than } 20 \mathrm{ft}\end{array}$ \\
\hline Maximize Interbed Continuity & Coefficient of variation $>0.60$ & Coefficient of variation between 0.30 and 0.60 & Coefficient of variation $<0.30$ \\
\hline Minimize Impact from Earthquakes & $\begin{array}{l}\text { Located in areas characterized by very thick } \\
\text { lacustrine sediments }\end{array}$ & $\begin{array}{l}\text { Located in areas characterized by a thicker section } \\
\text { of fluvially deposited sediments over basalt }\end{array}$ & $\begin{array}{l}\text { Located in areas characterized by veneer of } \\
\text { windblown sand over basalt }\end{array}$ \\
\hline $\begin{array}{l}\text { Maximize Distance from Volcanic Hazard } \\
\text { Zones }\end{array}$ & $\begin{array}{l}\text { Within } 5 \text { miles of volcanic vents less than } \\
400,000 \text { years old }\end{array}$ & $\begin{array}{l}\text { From } 5 \text { to } 9 \text { miles of volcanic vents less than } \\
400,000 \text { years old }\end{array}$ & $\begin{array}{l}\text { More than } 9 \text { miles from volcanic vents less than } \\
400,000 \text { years old }\end{array}$ \\
\hline $\begin{array}{l}\text { Locate to Facilitate Discriminatory } \\
\text { Monitoring }\end{array}$ & $\begin{array}{l}\text { Within contaminant plume, poorly developed } \\
\text { monitoring network }\end{array}$ & $\begin{array}{l}\text { Nearby contaminant plume, moderately developed } \\
\text { monitoring network }\end{array}$ & $\begin{array}{l}\text { Outside contaminant plume, well developed } \\
\text { monitoring network }\end{array}$ \\
\hline Availability of Geotechnical Data & $\begin{array}{l}\text { No nearby facilities or investigations provide } \\
\text { existing geotechnical data }\end{array}$ & $\begin{array}{l}\text { Geotechnical data from similar geologic setting } \\
\text { available }\end{array}$ & $\begin{array}{l}\text { Geotechnical data available from facilities or } \\
\text { investigations near the candidate site }\end{array}$ \\
\hline Availability of Characterization Data & $\begin{array}{l}\text { Few to no boreholes in the vicinity to provide } \\
\text { stratigraphic characterization data }\end{array}$ & Some borehole data available near candidate site & $\begin{array}{l}\text { Abundant borehole data available from facilities } \\
\text { near the candidate site }\end{array}$ \\
\hline \multicolumn{4}{|l|}{ HYDROLOGY } \\
\hline Minimize Proximity to Floodplains & Within extent of pluvial Lake Terreton & $\begin{array}{l}\text { Site located on or adjacent to the Big Lost River } \\
\text { floodplain and partially susceptible to inundation } \\
\text { from the } 500 \text {-year or } 1,000 \text {-year floods }\end{array}$ & $\begin{array}{l}\text { Site located on or adjacent to the Big Lost River } \\
\text { floodplain but outside } 1,000 \text {-yr floodplain } \\
\text { boundaries. }\end{array}$ \\
\hline Avoid Aquifer Recharge Areas & Within a recharge area & NA & Outside a recharge area \\
\hline $\begin{array}{l}\text { Avoid Areas of Surface Water } \\
\text { Flooding/Ponding }\end{array}$ & $\begin{array}{l}\text { Location where surface water may pond or } \\
\text { flood }\end{array}$ & Moderate surface water drainage & Good surface water drainage \\
\hline Avoid Perched Water & Location is in area with known perched water & $\begin{array}{l}\text { Location is in proximity of known or suspected } \\
\text { perched water }\end{array}$ & $\begin{array}{l}\text { Location is distant from known or suspected } \\
\text { perched water }\end{array}$ \\
\hline Avoid Wellhead Protection Areas & $\begin{array}{l}\text { Location within wellhead protection area, no } \\
\text { mitigation possible }\end{array}$ & $\begin{array}{l}\text { Location within wellhead protection area, } \\
\text { mitigation possible }\end{array}$ & Location outside wellhead protection area \\
\hline \multicolumn{4}{|l|}{ LAND USE } \\
\hline Located Within Core infrastructure Area & Location outside the core infrastructure area & NA & Location inside the core infrastructure area \\
\hline Avoid the Explosives Test Area & Within a designated area & Within a designated buffer around an area & Outside a designated buffer around an area \\
\hline Locate Near Utilities and Transportation & Greater than 1 mile & From 0.5 to 1 mile & Within 0.5 mile \\
\hline Avoid Industrial and Controlled Areas & $\begin{array}{l}\text { Within industrial or controlled area, no } \\
\text { mitigation possible }\end{array}$ & $\begin{array}{l}\text { Within or near industrial or controlled area, } \\
\text { mitigation possible }\end{array}$ & Outside an industrial or controlled area \\
\hline \multicolumn{4}{|l|}{ NATURAL RESOURCE } \\
\hline Avoid Sagebrush-Steppe Ecosystem Reserve & $\begin{array}{l}\text { Location within Sagebrush-Steppe Ecosystem } \\
\text { Reserve }\end{array}$ & NA & $\begin{array}{l}\text { Location outside Sagebrush-Steppe Ecosystem } \\
\text { Reserve }\end{array}$ \\
\hline Avoid Vegetation Transects & $\begin{array}{l}\text { Location within vegetation transect, no } \\
\text { mitigation possible }\end{array}$ & $\begin{array}{l}\text { Location within or near vegetation transect, } \\
\text { mitigation possible }\end{array}$ & Location outside vegetation transect \\
\hline Avoid Ecologically Sensitive Habitat & $\begin{array}{l}\text { Location within } 3 \text { miles of lekking sites, within } \\
1 / 2 \text { mile of raptor nests or pygmy rabbit burrows, } \\
\text { within sensitive plants zone }\end{array}$ & Location 3 to 11 miles from known lekking site & $\begin{array}{l}>11 \text { miles from lekking sites, }>1 / 2 \text { mile from } \\
\text { raptor nests or pygmy burrows, outside sensitive } \\
\text { plants zone, or within burn area }\end{array}$ \\
\hline
\end{tabular}


Table C-3. Evaluation of 34 candidate sites against 21 criteria.

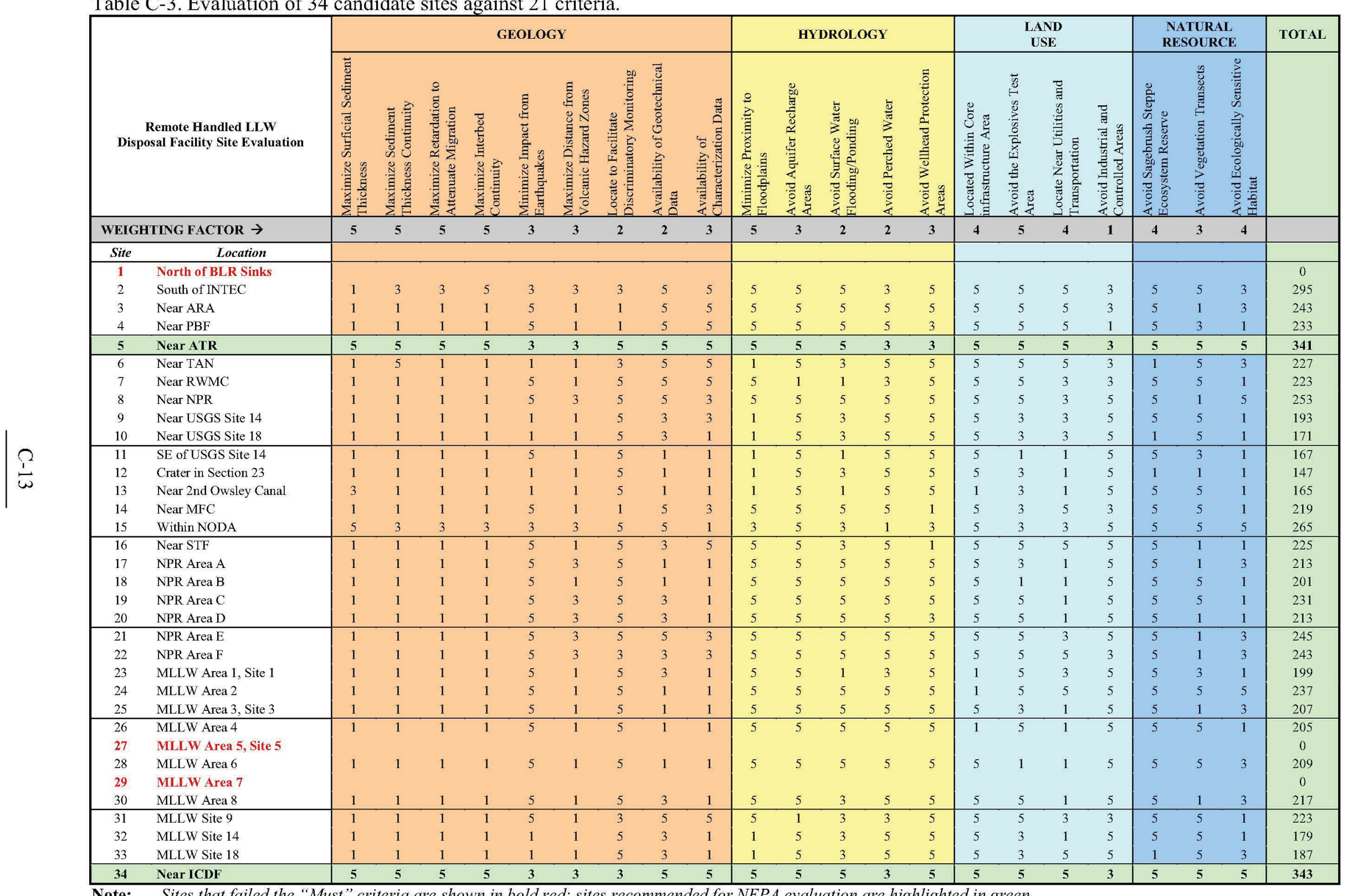




\section{C-2. GEOLOGY}

The proposed remote-handled LLW disposal facility sites that were determined to be satisfactory or conditionally satisfactory with respect to the "Must" criteria were further evaluated on the basis of nine identified "Want" geologic criteria. The criteria support evaluation of physical characteristics that are important to assess radionuclide migration, variable seismic response across the Idaho National Laboratory (INL), relationship of location to volcanic hazards, and a general assessment of the availability of characterization data. The importance of surficial sediment thickness to construction and thickness and grain size distribution to the performance assessment process warrants assigning a weighting factor of 5 to the first four criteria. The remaining five criteria are assigned a weighting factor of either 2 or 3 in recognition of their role in natural phenomena hazards assessment and in providing site-specific technical information (e.g., geotechnical and characterization data).

\section{C-2.1 [18] Maximize Surficial Sediment Thickness}

The thickness of surficial sediment is important to the design and construction of a remote-handled LLW disposal facility. Thicker accumulations of surficial sediments reduce the facility footprint. Thinner or non-existent accumulations may increase the complexity and cost of excavation and construction. Texture of these sediments also is important. Coarser fluvial sediments drain rapidly and reduce potential for groundwater incursion. Fine-grained lacustrine sediments enhance attenuation of radionuclides but drain slowly and increase the potential for groundwater incursion. This criterion was considered to be of very high importance and was assigned a weighting factor of 5 because thicker and coarser surficial sediments provide more design options. In addition, it is technically impractical to mitigate surficial sediment thickness.

A mean sediment thickness was determined wherever possible using geophysical logs and stratigraphic descriptions from boreholes located in the vicinity of the site. A surficial sediment thickness data set including 333 wells on or near the INL (Anderson, Liszewski, and Ackerman 1996) was used for this determination. For those sites where no borehole data were available, thicknesses were estimated using the surficial geology map (Figure C-1) and the surficial sediment thickness map (Figure C-2). In addition, textures were evaluated for all sites using the surficial geology map. As shown on the surficial geology map, most potential sites were located in areas with very thin to thin loess overlying basalt and surficial sediments were assumed to be less than $10 \mathrm{ft}$ thick. The surficial sediment thickness map presents the thickest distribution of sediments, typically exceeding $20 \mathrm{ft}$ and including fluvial deposits along the Big Lost River and lacustrine deposits of ancient Lake Terreton. Scores were assigned on the basis of total surficial thickness and texture: sites in areas with fluvial sediment thickness exceeding $20 \mathrm{ft}$ were assigned a score of 5; sites in areas with fluvial sedimentthickness ranging from 10 to $20 \mathrm{ft}$ were assigned a score of 3 ; and sites in areas with fluvial sedimentthickness less than $10 \mathrm{ft}$ or with lacustrine sediments were assigned a score of 1 .

Sites $2,5,6,9,10,15,32,33$, and 34 are located within the area of thickest sediments (Table C-4). Available lithologic data (Anderson, Liszewski, and Ackerman 1996) were used to refine the mean thickness for each site where possible. Based on this analysis, the mean fluvial sediment thicknesses for Sites 5,15 , and 34 exceeded $20 \mathrm{ft}$ and these sites were each assigned a score of 5 . Site 15 lies within the extent of thicker sediments and likely has fluvial sediment thickness exceeding $20 \mathrm{ft}$, based on two nearby wells (Holdren et al. 1997). The mean fluvial thickness for Site 2 was $17 \mathrm{ft}$. However, because Site 2 is characterized by widely varying thickness and basalt is exposed at the surface on the southern margin, that site was assigned a score of 1 . Sites $6,9,10,32$, and 33 were assigned surficial thickness scores of 1 because they are located in areas underlain by thicker lacustrine sediments. The remaining sites were located in areas characterized by thin to very thin loess. 


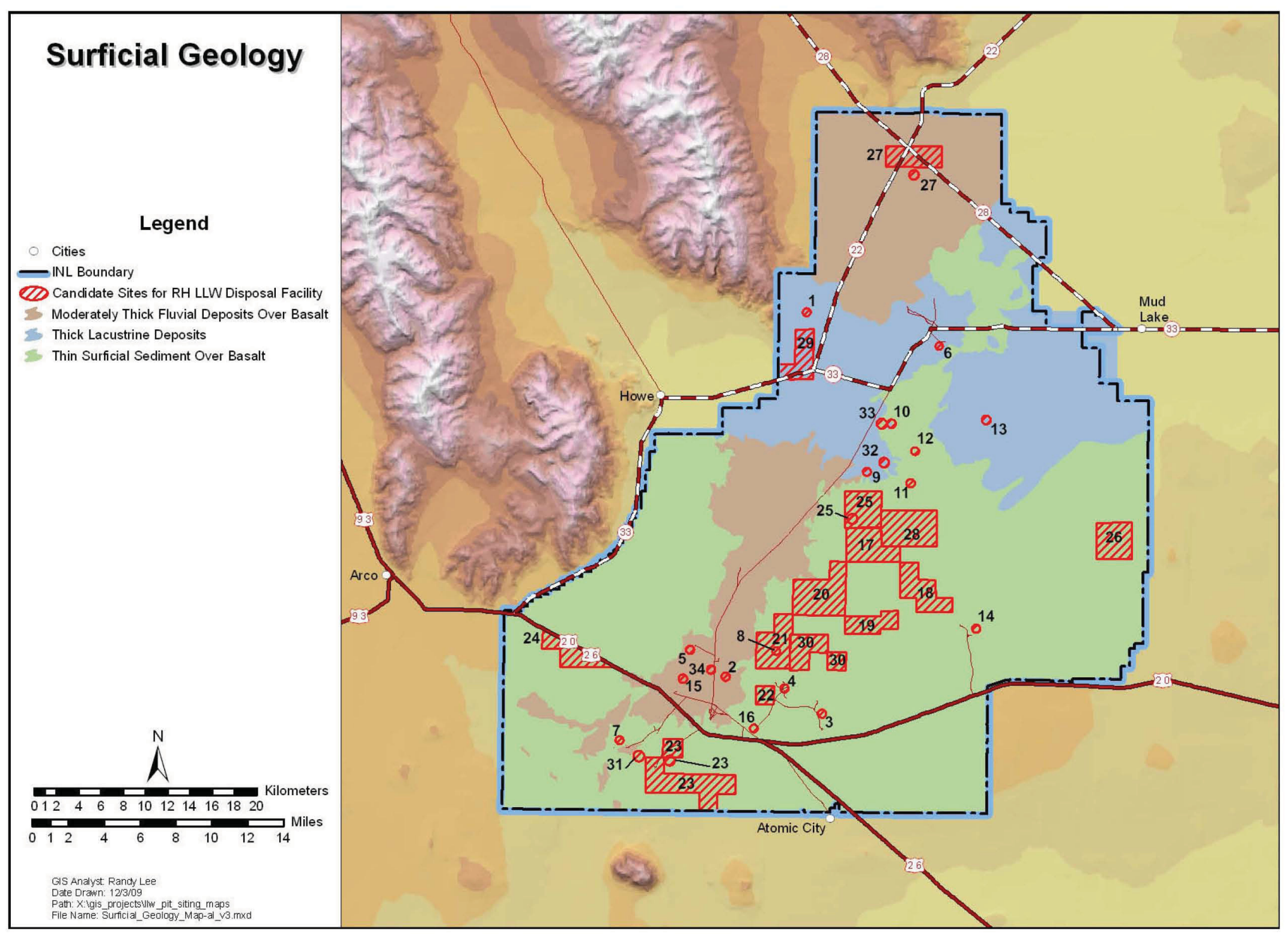

Figure C-1. Surficial geology. 


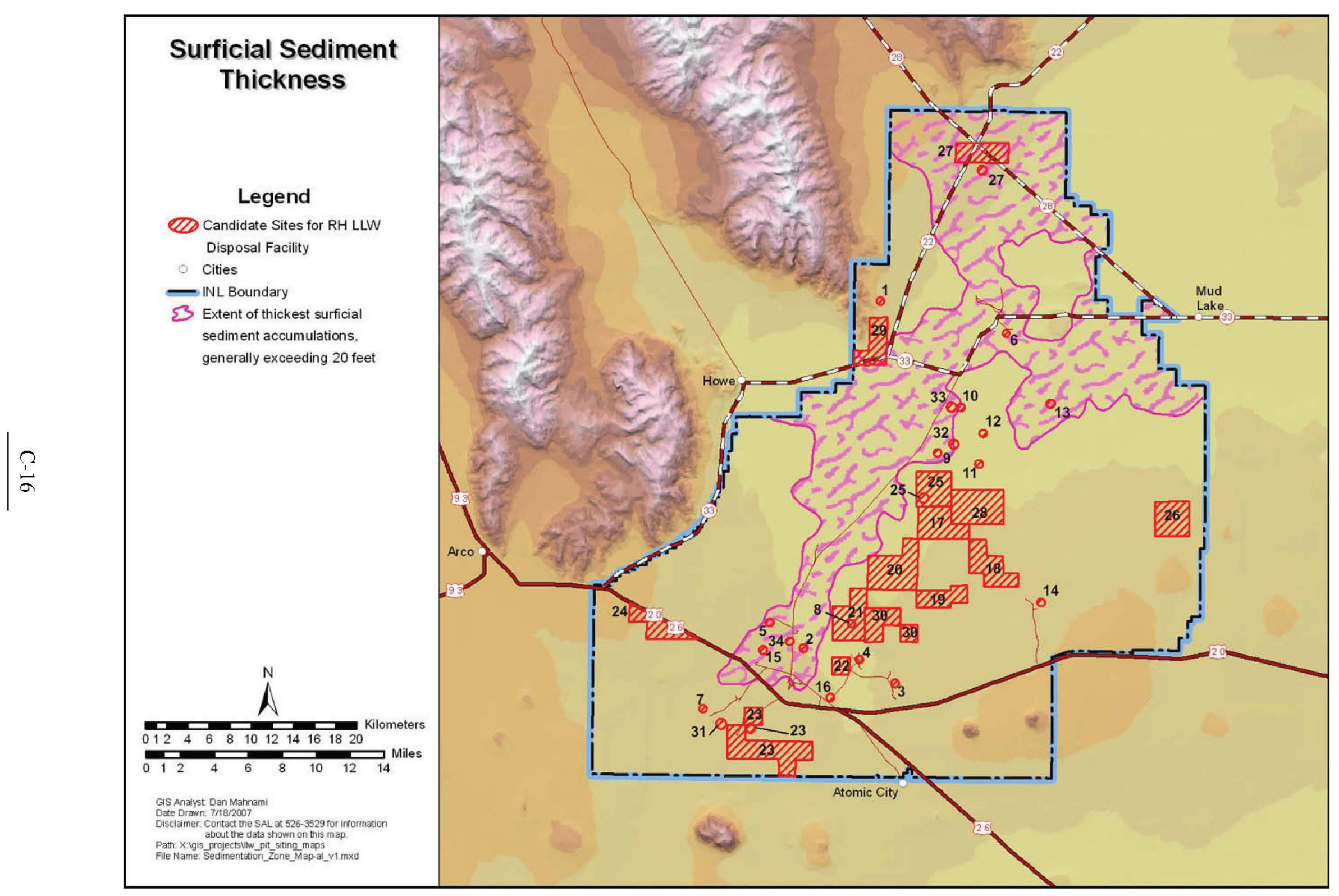

Figure C-2. Surficial sediment thickness. 
Table C-4. Surficial sediment thickness criterion score.

\begin{tabular}{|c|c|c|}
\hline Score & Sites & Scoring Rationale \\
\hline 5 & $5,15,34$ & $\begin{array}{l}\text { Mean fluvial sediment thickness for each site as determined from } \\
\text { lithologic data from nearby wells is }>20 \mathrm{ft} \text {. }\end{array}$ \\
\hline 3 & None & $\begin{array}{l}\text { Site } 2 \text { had a fluvial sediment thickness between } 10 \text { and } 20 \mathrm{ft} \\
\text { (leading to a score of } 3 \text { ); however, high variability limits vault } \\
\text { design to one high, increasing facility footprint significantly. Site } 2 \\
\text { was therefore scored in the next lower bracket (score of } 1 \text { ). }\end{array}$ \\
\hline 1 & $\begin{array}{l}2,3,4,6,7,8,9,10,11 \\
12,13,14,16,17,18,19 \\
20,21,22,23,24,25,26 \\
\quad 28,30,31,32,33\end{array}$ & $\begin{array}{l}\text { Site } 2 \text { had a mean thickness of } 17 \mathrm{ft} \text { with high variability. Sites } 6 \text {, } \\
9,10,32 \text {, and } 33 \text { are located in lacustrine deposits. The remaining } \\
22 \text { sites are located outside the zone of thickest surficial sediment } \\
\text { in thin to very thin loess. }\end{array}$ \\
\hline
\end{tabular}

In most areas, as indicated by borehole data, the elevation of the top of basalt and corresponding surficial sediment thickness can vary significantly over short distances. Even with multiple wells within a potential site, pressure ridges and flow lobes that locally reduce surficial sediment thickness may not be apparent. Final site selection should include site-specific characterization of surficial sediment thickness utilizing seismic and other characterization techniques.

\section{C-2.2 [19] Maximize Sediment Thickness Continuity}

Local variability in surficial sediment thickness could affect vault design of a remote-handled LLW disposal facility and transport of radionuclides released from the waste stored in the facility. A higher degree of continuity in surficial sediment thickness (smaller variability and less uncertainty) also reduces the range of ground motions stemming from potential earthquakes. This criterion was determined to be of very high importance and was assigned a weighting factor of 5 because maximizing continuity provides more design options. In addition, it is technically impractical to mitigate surficial sediment continuity.

The surficial sediment thickness data set compiled by Anderson, Liszewski, and Ackerman (1996) was used to evaluate continuity of surficial sediments. For those sites located near wells from this data set with available lithologic data, this criterion was scored using a calculated coefficient of variation (CV). This CV was calculated by dividing the standard deviation of the surficial sediment thicknesses by the mean thickness for wells adjacent to that site. This coefficient of variation permitted an assessment of the potential for thickness variability at the site. A calculated CV less than 0.30 provided the qualitative assessment that variations in sediment thickness were generally much smaller than the mean thickness; sites with a calculated CV less than 0.30 were assigned scores of 5 . A calculated CV between 0.30 and 0.60 provided the assessment that surficial sediment thickness varied by a moderate percentage of the mean thickness; sites with a calculated CV between 0.30 and 0.60 were assigned a score of 3 . A CV greater than 0.60 indicated that surficial sediment thickness varied significantly with respect to the mean thickness; sites with a calculated CV greater than 0.60 were assigned scores of 1 . All sites located in the area outside the extent of thick surficial sediments were assigned a score of 1 .

Coefficients of variation for surficial thickness continuity were calculated for Sites 2, 5, 6, 9, and 34 using available lithologic data from adjacent wells. The coefficients of variability for Sites 5, 6, and 34 were $0.19,0.21$, and 0.23 , respectively, indicating that thickness variations between wells were much smaller than the average thickness. Based on the coefficients of variation, these sites each were assigned scores of 5 (Table C-5). Minimal data are available for Site 15, but this site was assigned a score of 3 because of stratigraphic similarity to Sites 5 and 34. The coefficient of variation for Site 2 was 0.32 , 
indicating moderate changes in thickness between wells, and the site was assigned a score of 3 . The CV for Site 9 was 1.17, indicating that thickness variations were significant with respect to the average thickness, and the site was assigned a score of 1 . Sites 10,32, and 33 are located on the edges of the thick sediments and likely have variable surficial sediment thicknesses. These sites also were assigned surficial sediment thickness continuity scores of 1 . The remaining 23 sites located outside the area of thick surficial sediments were assigned surficial sediment continuity scores of 1 because of increased variation in surficial sediment thickness in those areas.

Table C-5. Surficial sediment continuity criterion score.

\begin{tabular}{|c|c|c|}
\hline Score & Sites & Scoring Rationale \\
\hline 5 & $5,6,34$ & $\begin{array}{l}\text { Coefficient of variation for Sites } 5,6 \text {, and } 34 \text { is }<0.30 \text {; Site } 15 \text { is } \\
\text { stratigraphically similar to Sites } 5 \text { and } 34 \text {. }\end{array}$ \\
\hline 3 & 2,15 & $\begin{array}{l}\text { Site } 2 \text { calculated CV was } 0.32 \text {. Site } 15 \text { has minimal data but may be } \\
\text { stratigraphically similar to nearby sites. }\end{array}$ \\
\hline 1 & $\begin{array}{l}3,4,7,8,9,10,11 \\
12,13,14,16,17,18 \\
19,20,21,22,23,24 \\
25,26,28,30,31,32 \\
\quad 33\end{array}$ & $\begin{array}{l}\text { Sites } 10,32 \text {, and } 33 \text { are on the edge of the thickest zone, but have } \\
\text { insufficient data to evaluate variability in surficial sediment thickness. } \\
\text { The remaining sites are located in zones of thin to very thin loess and } \\
\text { are likely characterized by limited to poor sediment thickness } \\
\text { continuity. }\end{array}$ \\
\hline
\end{tabular}

\section{C-2.3 [20] Maximize Retardation to Attenuate Migration}

Contaminants migrating downward through the vadose zone of the eastern Snake River Plain (ESRP) are attenuated as they come into contact with fine-grained sediments that occur in sedimentary interbeds. Attenuation is increased in those areas characterized by larger cumulative interbed thicknesses and larger fine-grained percentages. This criterion was determined to be of very high importance and was assigned a weighting factor of 5 because maximizing retardation attenuates contaminant migration through the vadose zone and decreases the impact on groundwater in the Snake River Plain Aquifer (SRPA). Mitigation of subsurface interbed thickness is technically impractical.

The assessment of the potential for contaminant retardation at sites consisted of estimation of the mean cumulative thickness of fine-grained sediments in interbeds above the water table; fine-grained surficial sediment thickness was not included in the cumulative thickness. In this assessment, the mean cumulative thickness of sedimentary interbeds was calculated using lithologic data from all wells adjacent to the site. This mean cumulative thickness was multiplied by the fine-grained percentage as defined by Holdren et al. (1997) to approximate the mean fine-grained thickness. The estimated mean fine-grained thicknesses were compared and scored as follows. Those sites with a thickness exceeding $20 \mathrm{ft}$ were considered to maximize attenuation and were assigned a score of 5 . Those sites with a thickness between 10 and $20 \mathrm{ft}$ were considered to provide some attenuation and were assigned a score of 3 . Those sites with a mean cumulative fine-grained thickness less than $10 \mathrm{ft}$ were considered to provide minimal attenuation and were assigned a score of 1 . For those sites with little or no interbed thickness or textural data, the retardation criterion was scored as 1.

Nine sites (Sites 2, 5, 6, 9, 10, 15, 32, 33, and 34) were evaluated using lithologic log data where possible (Table C-6). The mean fine-grained thickness for Sites 5 and 34 were estimated to be 31 and $23 \mathrm{ft}$, respectively. These sites were assigned a retardation score of 5 because the significant cumulative thicknesses of fine-grained sediments exceeded $20 \mathrm{ft}$ will maximize retardation. Site 15 is stratigraphically similar to Sites 5 and 34 and was assigned a score of 3 . The mean fine-grained thickness 
for Site 2 was $18 \mathrm{ft}$, and this site received a score of 3 . Minimal interbed data are available for Site 6, but cross sections constructed from well data at Test Area North (TAN) indicate that few thin and discontuous interbeds occur in the subsurface above the water table. Based on these cross sections, Site 6 was assigned a score of 1 . Sites 9, 10,32, and 33 have minimal interbed data to the water table but are located in proximity to the Axial Volcanic High, a region characterized throughout much of its depositional history by emplacement of a thick packet of basalt flows and few interbeds. These sites were each assigned a retardation score of 1.

Table C-6. Contaminant retardation criterion score.

\begin{tabular}{cll}
\hline Score & Sites & \multicolumn{1}{c}{ Scoring Rationale } \\
\hline 5 & 5,34 & The cumulative mean thickness for these sites exceeded $20 \mathrm{ft}$. \\
3 & 2,15 & $\begin{array}{l}\text { The cumulative mean thickness for site } 2 \text { was } 18 \mathrm{ft} \text {. Site } 15 \text { has } \\
\text { minimal data but may be stratigraphically similar to nearby sites. }\end{array}$ \\
\hline & $\begin{array}{l}3,4,6,7,8,9,10,11,12, \\
13,14,16,17,18,19,20,\end{array}$ & $\begin{array}{l}\text { Sites } 6,9,10,15,32, \text { and } 33 \text { have insufficient data to evaluate } \\
\text { interbed thickness. The remaining 22 sites are located in proximity } \\
\text { to the Axial Volcanic High s and are likely characterized by } \\
\text { limited to poor interbed thickness and fine-grained texture. }\end{array}$ \\
& $\begin{array}{l}21,22,23,24,25,26,28, \\
30,31,32,33\end{array}$
\end{tabular}

Twenty-two sites are located on the Axial Volcanic High that extends across the eastern half of the INL from the north to the south or in areas without site-specific data. Lithologic data at the INL indicate that the number and thickness of interbeds decrease in the vicinity of the axial volcanic high. Sites with little data or that are located on the Axial Volcanic High were assigned a retardation score of 1.

\section{C-2.4 [21] Maximize Interbed Continuity}

Lateral continuity of fine-grained sediments in the vadose zone at a potential site promotes retardation of downward-migrating contaminants. This criterion was determined to be of very high importance and was assigned a weighting factor of 5 because maximizing continuity of sedimentary interbeds reduces the contaminant transport uncertainties associated with highly variable thicknesses of fine-grained sediments within the vadose zone and increases retardation capacity. Mitigation of subsurface interbed continuity is technically impractical.

The potential for continuity was evaluated for those sites with lithologic data available from adjacent wells. Several geostatistical studies have been conducted that provide site-specific analyses of interbed continuity. Cahn et al. (2006) conducted a geostatistical analysis of interbed continuity at INTEC. This study indicated large heterogeneity in interbed thickness and continuity. Leecaster (2004) noted similar heterogeneity in interbed thickness and continuity at the RWMC. On a larger scale, Wood et al. (2007) observed the large-scale complexity of interbed distribution controlled by multiple sediment sources and complicated by ever-changing basalt terrain. These studies imply that variability in the number of interbeds between wells in an area may not necessarily be a good indicator of interbed continuity.

The present evaluation utilized a lithologic data set from Anderson et al. (1996) that included stratigraphic data from 333 wells at or near the INL. This evaluation provided a source of subsurface data immediately adjacent to the potential sites. Recognizing the large variability in interbed thickness and 
continuity at the INL, evaluation results were generally supported by larger-scale statistical results using data sets that were derived from the above-mentioned geostatistical studies and INL borehole data base 1 .

The evaluation consisted of determination of the number of vadose-zone interbeds in each characterization well and calculation of the mean and standard deviation of the number of interbeds. A CV was determined by dividing the standard deviation by the mean number of interbeds. Those sites with a CV less than 0.30 were assigned a score of 5 , indicating good continuity of interbeds. Those sites with a $\mathrm{CV}$ between 0.30 and 0.60 were assigned a score of 3 , indicating a moderate continuity of interbeds. Those sites with a CV greater than 0.60 were assigned a score of 1 , indicating little continuity of interbeds. For those sites with little or no interbed thickness data, the interbed continuity criterion was scored as 1 .

Sites $2,5,6,9,10,15,32,33$, and 34 are located in the vicinity of the Big Lost Trough and the Lake Terreton area where sedimentary interbeds commonly occur (Table C-7). These sites were evaluated using lithologic log data (Anderson et al. 1996) where possible. Sites 2, 5, and 34 were assigned an interbed continuity score of 5 because the coefficients of variation for these sites ranged from .04 to 0.09 , indicating that interbeds within the vadose zone at those sites are reasonably continuous. Site 15 was assigned a score of 3 because it is stratigraphically similar to Sites 2, 5, and 34. Site 6 was assigned a score of 1 , based on a stratigraphic cross-section that indicates that interbeds at that site are relatively discontinuous. Sites 9,10,32, and 33 have little or no available sedimentary interbed data but are located on the eastern margins of the Big Lost Trough, likely are characterized by few interbeds, and were assigned a score of 1 for interbed continuity. The remaining 22 sites are located in proximity to the Axial Volcanic High in areas typically characterized by fewer and coarser sedimentary interbeds. These sites were assigned an interbed continuity score of 1 .

Table C-7. Continuity of sedimentary interbeds criterion.

\begin{tabular}{|c|c|c|}
\hline Score & Sites & Scoring Rationale \\
\hline 5 & $2,5,34$ & $\begin{array}{l}\text { CV for Sites } 5 \text { and } 34 \text { were }<0.30 \text {; Site } 15 \text { is stratigraphically similar to } \\
\text { sites } 5 \text {, and } 34 \text {. }\end{array}$ \\
\hline 3 & 15 & $\begin{array}{l}\text { Site } 15 \text { has minimal data but may be stratigraphically similar to nearby } \\
\text { sites. }\end{array}$ \\
\hline 1 & $\begin{array}{l}3,4,6,7,8,9,10 \\
11,12,13,14,16 \\
17,18,19,20,21 \\
22,23,24,25,26 \\
28,30,31,32,33\end{array}$ & $\begin{array}{l}\text { Site } 6 \text { was scored on the basis of cross-section data. Sites } 9,10,32 \text {, and } \\
33 \text { have insufficient data, but are located on the margins of the Big Lost } \\
\text { Trough in an area of decreasing sedimentary interbeds. The remaining } \\
\text { sites are located in proximity to the Axial Volcanic High and are likely } \\
\text { characterized by limited to poor interbed continuity and coarser texture. }\end{array}$ \\
\hline
\end{tabular}

\section{C-2.5 [22] Minimize Impact from Earthquakes}

Ground motion derived from earthquakes could impact the LLW disposal site. Higher ground motion could result in damage to cells and radioactive contaminant release to the environment. The INL is located on the ESRP adjoining the seismically active basin and range province; however, the ESRP is relatively aseismic, based on seismic hazard maps constructed by the United States Geological Survey (USGS) (Peterson et al. 2008) from earthquake data for the western United States. In addition, ground motions derived from studies conducted by URS Greiner Woodward-Clyde Federal Services et al.

\footnotetext{
${ }^{1}$ Schafer, Annette (BEA), and Jeff Sondrup (BEA), personal communication with Brennon Orr (North Wind, Inc.), "Statistical Analysis of Lithologic Continuity Data," September 28, 2009.
} 
(1999 and 2000), and Woodward-Clyde Federal Services et al. (1996) were lower than those derived from the USGS.

Figure C-3, derived from the USGS seismic hazard maps, presents the 0.2 second spectral period peak ground acceleration for the $2 \%$ probability of exceedance in 50 years. Based on this map, the difference in ground acceleration at the INL ranges from approximately 32 to $40 \% \mathrm{~g}$. For longer post-closure periods (e.g., 10,000 years), the probability of a maximum event is large; however, the small ground acceleration (less than $40 \% \mathrm{~g}$ ) minimizes the potential risk to the facility. Also, facility design can be engineered to lessen the impact of earthquakes that may occur in the adjoining regions. This criterion was determined to be of medium importance and was assigned a weighting factor of 3 .

The range of ground acceleration shown on Figure C-3 was not sufficient to differentiate INL sites with respect to this criterion. In a previous study, soils and rock at INL facility areas were classified based on surficial sediment layer thickness and calculated average shear wave velocities ${ }^{2}$. In that study, available geotechnical data were used to evaluate soil types and thickness at INL facility areas. The Radioactive Waste Management Complex (RWMC), Power Burst Facility (PBF), and Materials and Fuels Complex (MFC) were associated with thin sediments (less than $3 \mathrm{~m}$ ) over basalt and were assigned a soil and rock site classification of $\mathrm{B}$, indicating small potential impact from earthquakes. The Idaho Nuclear Technology and Engineering Center (INTEC), Advanced Test Reactor (ATR), and Naval Reactors Facility (NRF) were associated with sediments ranging from $3 \mathrm{~m}$ to $15 \mathrm{~m}$ in thickness were assigned a soil and rock classification of $\mathrm{C}$, indicating a moderate impact. The TAN area was assigned a classification of $\mathrm{D}$ because of the velocity contrasts between basalt and overlying thick lacustrine sediments. Based on this study and the surficial geology map (superimposed on Figure C-3), LLW sites located in areas geologically similar to the RWMC, PBF, and MFC (veneer of windblown sand over basalt) were assigned earthquake impact criterion scores of 5. Sites located in areas geologically similar to the INTEC, ATR, and NRF (thicker section of fluvially deposited sediments over basalt) were assigned scores of 3. Sites located in areas geologically similar to TAN (very thick lacustrine sediments) were assigned scores of 1 .

Based on Figure C-3, Sites 3, 4, 7, 8, 11, 14, 16 through 26, 28, 30, and 31 were assigned scores of 5 because they are located in areas characterized by thinner surficial sediments and decreased potential impact from earthquakes (Table C-8). Sites 2, 5, 15, and 34 were assigned scores of 3 because they are located in areas where increased sediment thickness may increase the potential for earthquake impact. Sites $6,9,10,12,13,32$, and 33 were assigned scores of 1 because they are located in areas of thick lacustrine sediments with greatest potential for earthquake impact.

Table C-8. Impact of earthquake criterion.

\begin{tabular}{ccl}
\hline Score & Sites & \multicolumn{1}{c}{ Scoring Rationale } \\
\hline 5 & $\begin{array}{c}3,4,7,8,11,14,16,17,18,19,20, \\
21,22,23,24,25,26,28,30,31\end{array}$ & $\begin{array}{l}\text { Sites located in areas characterized by thin, } \\
\text { windblown sediments overlying basalt. }\end{array}$ \\
\hline 3 & $2,5,15,34$ & $\begin{array}{l}\text { Sites located in areas characterized by thicker sections } \\
\text { of fluvial sediments overlying basalt. }\end{array}$ \\
\hline 1 & $6,9,10,12,13,32,33$ & $\begin{array}{l}\text { Sites located in areas characterized by thick sections } \\
\text { of lacustrine sediments. }\end{array}$ \\
\hline
\end{tabular}

\footnotetext{
${ }^{2}$ Suzette Payne, INL, e-mail to Brennon Orr, North Wind, "IBC Site Classes," October 28, 2009.
} 


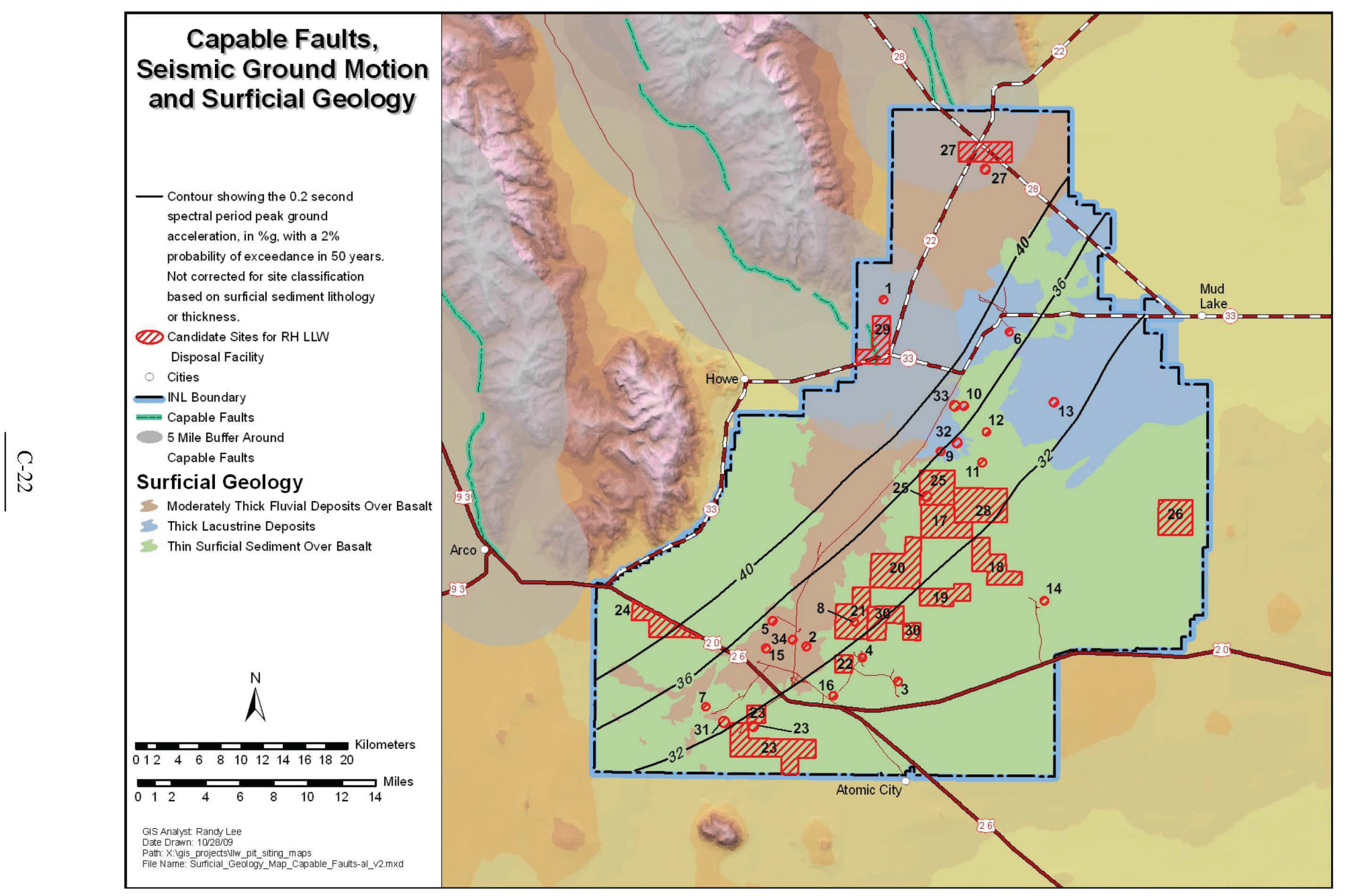

Figure C-3. Capable faults and seismic ground motion. 


\section{C-2.6 [23] Maximize Distance from Volcanic Hazard Zones}

This criterion was developed to minimize the hazards of inundation from volcanic eruption. Sites were evaluated on the basis of proximity to volcanic vents based on a volcanic hazard study conducted as part of the New Production Reactor (NPR) assessment. Although location of a facility near a known volcanic vent is not desirable and proximity to a volcanic vent increases subsurface variability, the probability of a volcanic event remains several orders of magnitude lower than the probability of a seismic event.

However, the probability of lava inundation at a site is reasonably large for post-closure periods of several thousands of years. For lava inundation, preliminary thermal modeling studies indicated that, for a 10 -m thick lava flow, the $300^{\circ} \mathrm{C}$ isotherm would penetrate to a depth of less than $3 \mathrm{~m}$ (Hackett, W.R., written communication, 1994). If the potential of lava inundation at the recommended sites during the extended post-closure time frame is too great to disregard, then steps should be taken in the conceptual design and design phases to assure sufficient depth of burial to protect against damage. First, potential sites should accommodate burial at sufficient depth to prevent thermal damage to waste and waste containers. Second, the thermal effects of lava inundation on stored waste materials can be mitigated by post-closure facility design. This design should be based on thermal modeling using site-specific material properties and emplacement temperatures consistent with those of ESRP basalt lavas. This criterion was determined to be of medium importance and assigned a weighting factor of 3 because the probability of occurrence is much lower than seismic or flooding events and because of the potential to mitigate through design.

Figure C-4 presents a volcanic hazard zone map, derived from the NPR assessment (Hackett, Smith, and Khericha 2002), which delineates zones of highest hazard (within 5 mi of a known volcanic vent younger than 400,000 years) and lower hazard (from 5 to $9 \mathrm{mi}$ of a known volcanic vent younger than 400,000 years). Those sites outside the delineated volcanic hazard zone were assigned a score of 5 . Sites that were located within the lower volcanic hazard zone were assigned a score of 3 . Sites located within the highest volcanic hazard zone were assigned a score of 1 .

Based on the volcanic hazard map (Figure C-4), Sites 2, 5, 8, 15, 17, 19 through 22, and 34 were assigned a score of 3 because they are located at distances from 5 to $9 \mathrm{mi}$ from identified volcanic hazards (Table C-9). Sites 3, 4, 6, 7, 9 through 14, 16, 18, 23 through 26, 28, and 30 through 33 were assigned a score of 1 because they all are located within $5 \mathrm{mi}$ of volcanic hazards. No sites were outside identified volcanic hazard zones.

Table C-9. Volcanic hazards criterion.

\begin{tabular}{ccl}
\hline Score & Sites & \multicolumn{1}{c}{ Scoring Rationale } \\
\hline 5 & None & $\begin{array}{l}\text { Sites located greater than } 9 \text { miles from } \\
\text { volcanic hazard zones. }\end{array}$ \\
\hline 3 & $2,5,8,15,17,19,20,21,22,34$ & $\begin{array}{l}\text { Sites located within } 5 \text { to } 9 \text { miles of volcanic } \\
\text { hazard zones. }\end{array}$ \\
\hline 1 & $3,4,6,7,9,10,11,12,13,14,16,18,23,24$, & $\begin{array}{l}\text { Sites located less than } 5 \text { miles from } \\
\text { volcanic hazard zones. }\end{array}$ \\
\hline
\end{tabular}




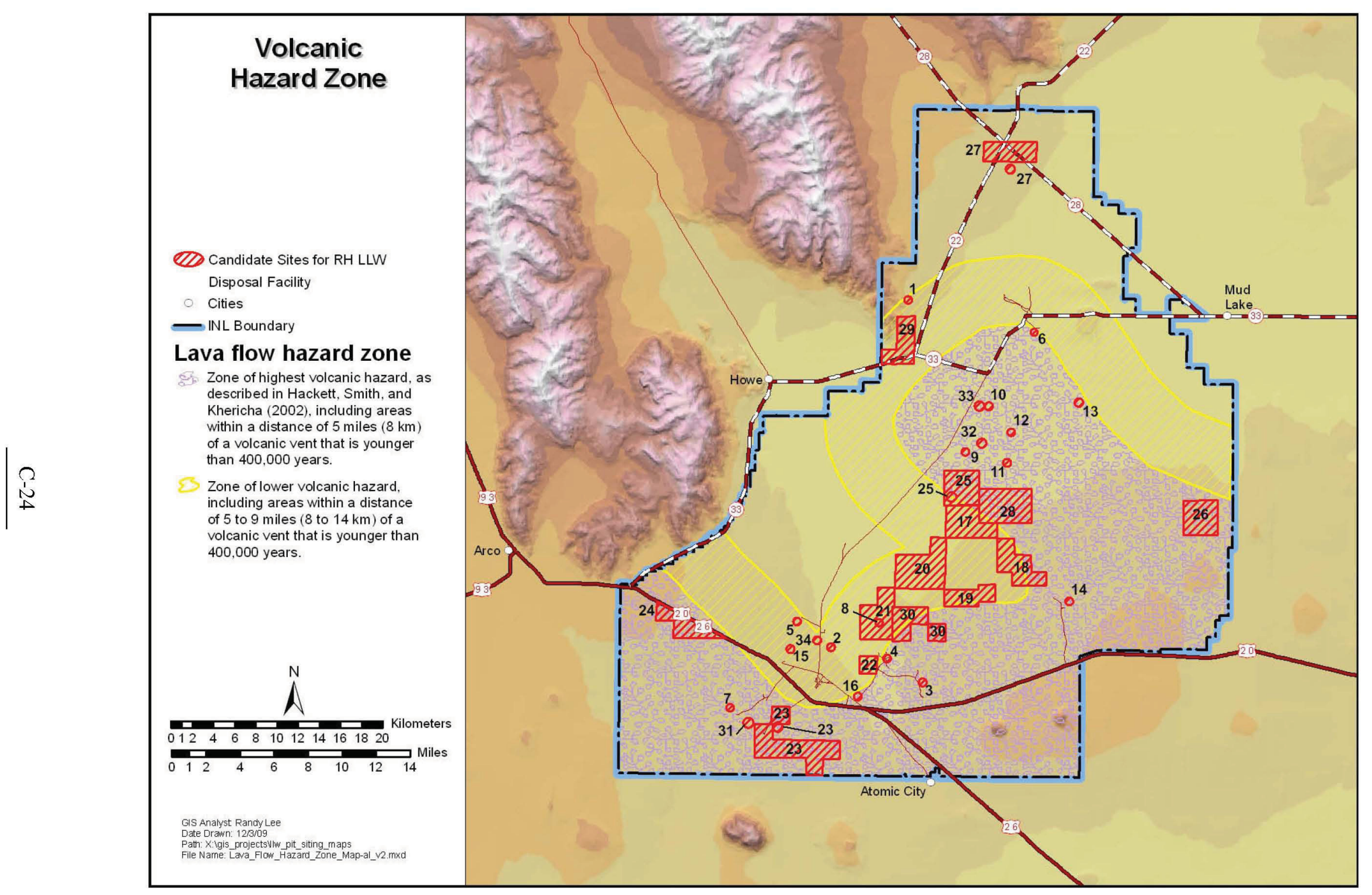

Figure C-4. Zones of highest volcanic hazards) (areas within a distance of $5 \mathrm{mi}$ of a volcanic vent younger than 400,000 years) and lower volcanic hazards (areas between 5 and 9 mi of a volcanic vent younger than 400,000 years). 


\section{C-2.7 [24] Locate to Facilitate Discriminatory Monitoring}

This criterion was developed to evaluate the potential to discriminate between the effects of accidental contaminant release from the remote-handled LLW disposal facility and the effects of contaminants released from other facilities. The INL has an existing monitoring network that has identified contaminant plumes in localized areas across the site. Because the plume locations are well known, numerical models are able to predict their behavior (contaminant transport), and monitoring networks are in place or can be installed, the discriminatory monitoring criterion was considered to be of low importance and was assigned a weighting factor of 2 .

Much of the INL remains uncontaminated from site operations. In those areas, discriminatory monitoring would not require extensive background data to identify potential releases from a LLW facility. Sites in those areas were assigned scores of 5. In parts of the INL, existing radionuclide contamination in the subsurface increases the difficulty in discrimination of low concentrations of contaminant migration that may indicate a potential release. In those areas, sites with well-developed monitoring systems that provide for historical trends and contaminant ratios will permit identification of releases from the facility and were assigned scores of 5 . Sites with some existing monitoring wells were assigned scores of 3 . Sites in contaminated areas with a minimal number of monitoring wells were assigned scores of 1 .

Based on site locations with respect to known contaminant plumes at the INL, Sites 8 through 13, 16 through 21,23 through $26,28,30,32$, and 33 were each assigned a score of 5 because they are located outside areas of radionuclide contamination (Table C-10). Sites 5, 7, and 15 were each assigned a score of 5 because they are in proximity to known contaminant plumes but are in areas with well-developed monitoring networks. Sites 2 and 34 are located in a well-monitored area but are in such close proximity to pre-existing contaminant plumes emanating from Idaho INTEC that they were assigned scores of 3. Site 6 was assigned a score of 3 because it is located in proximity to the TAN contaminant plume and has few downgradient monitoring wells. Sites 22 and 31 were each assigned a score of 3 because of their proximity to the existing facilities (PBF and the RWMC) with moderately developed downgradient monitoring networks. Site 3 is located at Auxiliary Reactor Area (ARA). In 2006, a soil survey indicated $17.3 \mathrm{pCi} / \mathrm{g}$ at ARA, the site of the 1961 Stationary Low-Power Reactor 1 (SL-1) accident and subsequent cleanup, which left residual contamination throughout soil surrounding the facility (DOE-ID 2007). Discriminatory monitoring at this site would require development of an extensive monitoring system. Site 4 is located at the PBF. Site 14 is located at MFC in proximity to the Radioactive Scrap and Waste Facility (RSWF). These three sites were each assigned a score of 1 because they are located in areas of potential contamination and have minimal groundwater monitoring and characterization networks. 
Table C-10. Continuity of discriminatory monitoring criterion.

\begin{tabular}{|c|c|c|}
\hline Score & Sites & Scoring Rationale \\
\hline 5 & $\begin{array}{l}5,7,8,9,10,11,12 \\
13,15,16,17,18,19 \\
20,21,23,24,25,26 \\
28,30,32,33\end{array}$ & $\begin{array}{l}\text { Sites } 5,7 \text {, and } 15 \text { in proximity to contaminant plumes, but with well } \\
\text { developed monitoring networks. All other sites are located away from } \\
\text { contaminant plumes. }\end{array}$ \\
\hline 3 & $2,6,22,31,34$ & $\begin{array}{l}\text { Sites } 2 \text { and } 34 \text { located immediately adjacent to contaminant plumes, } \\
\text { but with well developed monitoring networks. Sites } 6,22 \text {, and } 34 \text { are } \\
\text { located in proximity to facilities with some monitoring networks. }\end{array}$ \\
\hline 1 & $3,4,14$ & $\begin{array}{l}\text { Site } 3 \text { located near ARA with little downgradient monitoring } \\
\text { capability. Site } 4 \text { located at PBF with little downgradient monitoring } \\
\text { capability. Site } 14 \text { located at MFC in proximity to the RSWF and } \\
\text { with little downgradient monitoring capability. }\end{array}$ \\
\hline
\end{tabular}

\section{C-2.8 [25] Availability of Geotechnical Data}

Geotechnical data consist of those engineering data that pertain to soil and rock classification and mechanical properties and that are used in the design phase of the facility. Geotechnical data have been collected primarily in proximity to existing facilities. Some geotechnical data are available from environmental monitoring sites (Figure C-5) and from monitoring well sites (Figure C-6). This criterion was determined to be of low importance and was assigned a weighting factor of 2 because additional data can be obtained through characterization studies at relatively low cost.

Those sites located away from existing facilities and where no geotechnical data are available were assigned a score of 1 . Sites that are similar to other sites with existing geotechnical data were assigned a score of 3. Sites in proximity to existing facilities or where geotechnical studies have been conducted were assigned a score of 5 .

The assessment of geotechnical data was based on maps showing existing facilities and monitoring sites. Those sites where geotechnical data are available because of nearby facilities or investigations were assigned a score of 5. Sites where geotechnical data were available from similar geologic settings were assigned a score of 3 . Sites with no nearby facilities or investigations were assigned a score of 1 .

Sites 2 through $8,14,15,21,31$, and 34 were assigned a score of 5 because they are located in proximity to existing facilities or investigations with existing geotechnical data (Table C-11). Sites 9, 10, $16,19,20,22,23,30,32$, and 33 were assigned a score of 3 because they were in areas that could be correlated to areas with existing geotechnical data. Sites 11,12, 13, 17, 18, 24 through 26, and 28 were assigned a score of 1 because they all are located away from facilities or investigations, have minimal available geotechnical data, and are not easily correlated to other sites. 
Table C-11. Continuity of availability of geotechnical data criterion.

\begin{tabular}{ccl}
\hline Score & Sites & \multicolumn{1}{c}{ Scoring Rationale } \\
\hline 5 & $2,3,4,5,6,7,8,14,15,21$, & $\begin{array}{l}\text { Existing geotechnical data available from adjacent facilities } \\
\text { or studies. }\end{array}$ \\
\hline 31,34 & $\begin{array}{c}\text { 9, 10,16,19,20,22,23,30, } \\
32,33\end{array}$ & $\begin{array}{l}\text { Sites are in geologic settings similar to those with } \\
\text { geotechnical data. }\end{array}$ \\
\hline \multirow{3}{*}{$\begin{array}{c}11,12,13,17,18,24,25,26, \\
28\end{array}$} & Minimal geotechnical data available. \\
\hline
\end{tabular}

\section{C-2.9 [26] Availability of Characterization Data}

The availability of characterization data criterion is focused primarily on subsurface data. This criterion includes data subsets used to evaluate surficial and interbed thicknesses in criteria 1 through 4, site specific data to evaluate impacts of earthquakes and volcanic hazards in criteria 5 and 6 , as well as site-specific hydrogeologic characterization. This criterion is defined by the availability of borehole data at or adjacent to the site. The spatial distribution of boreholes provides a relative measure of characterization. This criterion was determined to be of medium importance and was assigned a weighting factor of 3 because borehole characterization data could be obtained through additional characterization studies that can provide a quantitative assessment of the adequacy of a specific site. 


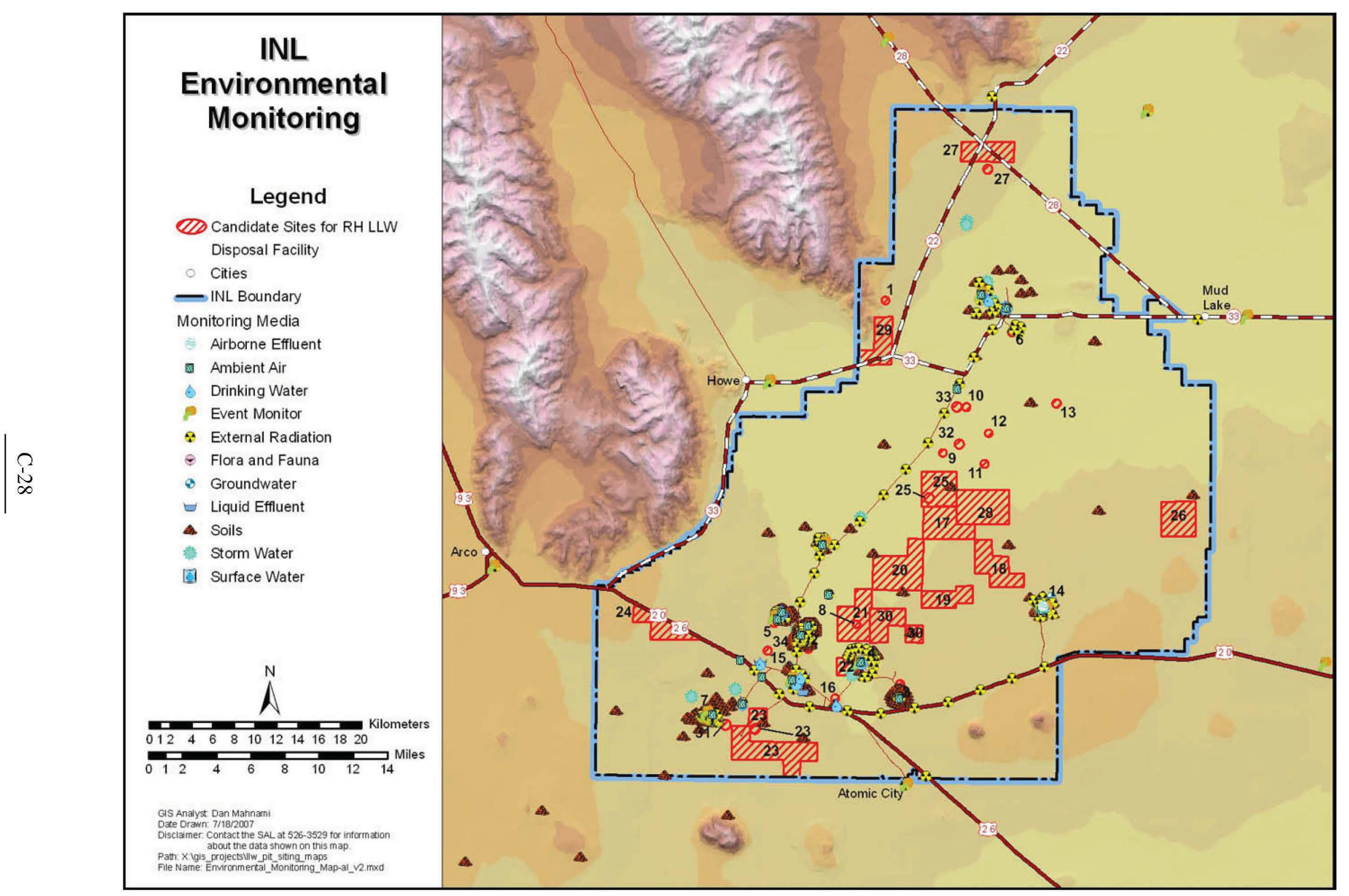

Figure C-5. Environmental monitoring. 


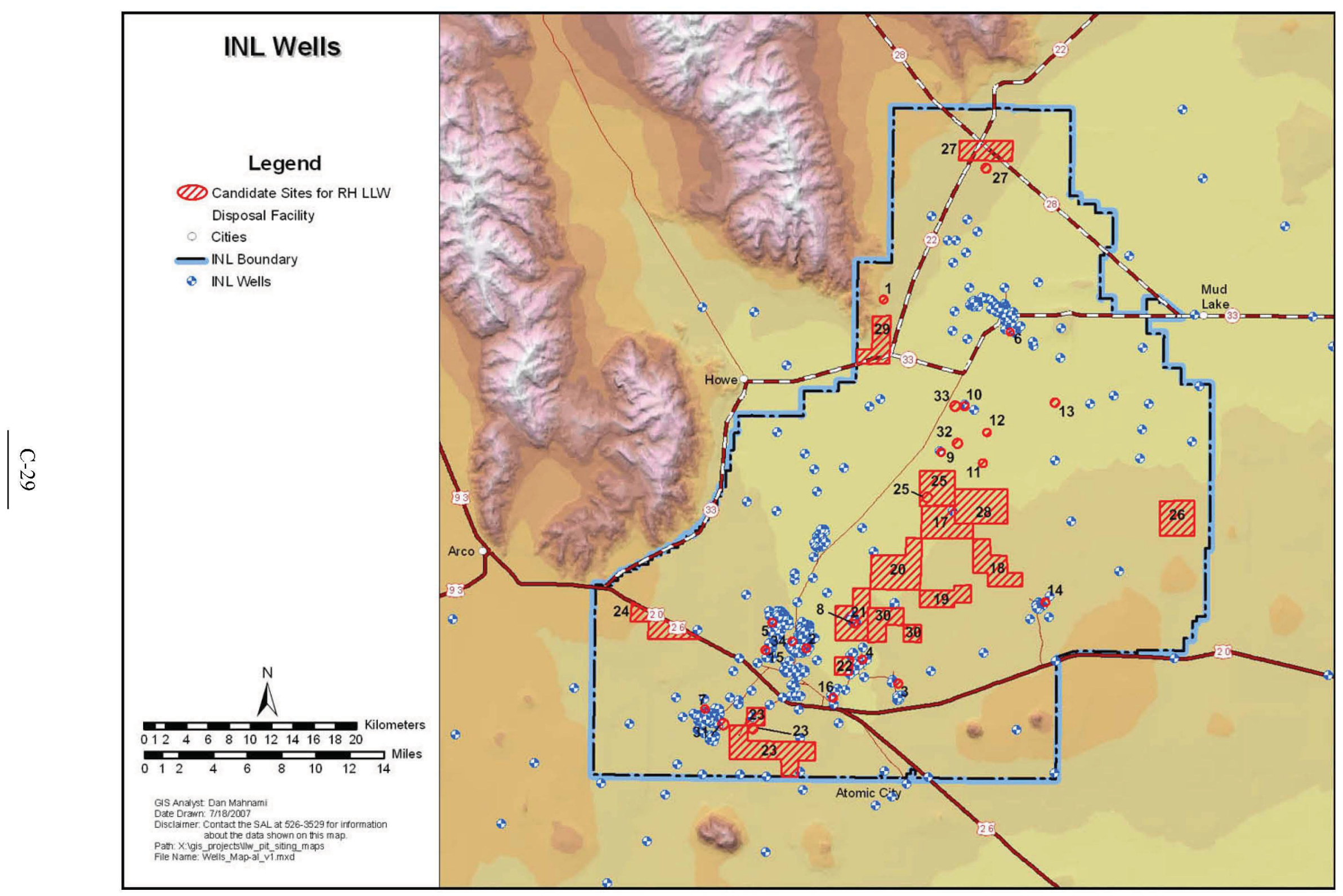

Figure C-6. Idaho National Laboratory wells. 
Figures C-5 and C-6 show the location environmental data monitoring sites and INL monitoring wells. Based on these figures, sites where borehole data from nearby facilities are abundant were assigned a score of 5 . Sites where some borehole data are available were assigned a score of 3 . Sites with minimal borehole data were assigned a score of 1.

Based on Figures C-5 and C-6, Sites 2 through 7, 16, 31, and 34 were assigned a score of 5 because they are located in areas with abundant borehole characterization data (Table C-12). Sites 8, 9, 14, 21, and 22 were assigned a score of 3 because they were in areas with some borehole data. Sites 10 through 13, 15,17 through 20,23 through $26,28,30,32$, and 33 were assigned a score of 1 because they all are located in areas with minimal available borehole data.

Table C-12. Availability of characterization criterion.

\begin{tabular}{ccl}
\hline Score & \multicolumn{1}{c}{ Sites } & \multicolumn{1}{c}{ Scoring Rationale } \\
\hline 5 & $2,3,4,5,6,7,16,31,34$ & $\begin{array}{l}\text { Sites are located in areas where borehole data } \\
\text { are abundant. }\end{array}$ \\
\hline 3 & $8,9,14,21,22$ & $\begin{array}{l}\text { Sites are located in areas where some borehole } \\
\text { data are available. }\end{array}$ \\
\hline 1 & $10,11,12,13,15,17,18,19,20,23,24,25$, & $\begin{array}{l}\text { Sites are located in areas with minimal borehole } \\
\text { data. }\end{array}$ \\
\hline
\end{tabular}

\section{C-3. HYDROLOGY}

The proposed LLW disposal facility sites that were determined to be satisfactory or conditionally satisfactory with respect to the "Must" criteria were further evaluated on the basis of five identified "Want" hydrological criteria. These criteria consist of:

1. Minimization of proximity to floodplains

2. Avoidance of wellhead protection areas

3. Avoidance of aquifer recharge areas

4. Avoidance of areas that are susceptible to ponding and flooding

5. Avoidance of areas overlying perched groundwater.

\section{C-3.1 [29] Minimize Proximity to Floodplains}

The "Must" criterion "Must Not be Located in the 500-year Floodplain" (Section B-2.1.2) addresses flooding during an operational or shorter term post-closure timeframes but does not adequately address longer post-closure timeframes (e.g., 10,000 years). Flooding could occur within longer post-closure periods in response to formation of pluvial lakes associated with a return to a glacial cycle (e.g., 1,000 to 10,000 years). Because of a reasonable probability of post-closure timeframe flooding events on the eastern Snake River Plain and because of the requirement to keep the facility dry, this criterion was determined to be of very high importance and was assigned a weighting factor of 5 . 
A flooding hazard evaluation for a PC-1 facility is based on a mean annual probability of $2 \times 10-3$, equivalent to a 500 -year flood. The flood hazard input can be derived from flood insurance studies or their equivalent. Flood insurance studies have been conducted for areas along the Big Lost River upstream from the INL but have not been conducted on the INL. However, the Bureau of Reclamation conducted an equivalent study (Ostenaa and O'Connell 2005) that provides inundation maps for floods with different recurrence intervals (including the 500-year flood) for the Big Lost River channel extending from the spreading area diversion to approximately 3 mi downstream from INTEC and the ATR Complex. Flood flow rates include an estimate of the design basis flood for a Performance Category 1 facility, equivalent to the 500-year flood flow rate. No inundation maps are available for the 500-year flood downstream from the Bureau of Reclamation study area.

The overall extent of the 500-year flood at the scale of the INL is shown in Figure C-7, while Figures C-8 and C-9 show a more detailed view of the 100-year and 500-year floods. Figure C-10 compares the 500,1,000, and 10,000-year floodplains in the vicinity of the INTEC and ATR. Figure C-7 also shows the extent of pluvial Lake Terreton. During a glacial cycle, sites located within the pluvial lake boundary would likely be inundated as the lake filled.

For this criterion, a site located outside the extent of inundation from the 500-year and 1,000-year flood and outside the Lake Terreton boundary was assigned a score of 5 . A site on the Big Lost River floodplain that could be partially inundated by the 1,000-year flood was assigned a score of 3 . A site within the Lake Terreton boundary was assigned a score of 1 . Table C-13 outlines the sites and their respective scores.

Sites 2, 5, and 34 were assigned a score of 5 because they are located on the BLR floodplain but are outside the extent of the 500-year or 1,000-year floodplain. Sites 3-5, 7, 8, 14, 16-26, 28, 30, and 31, were assigned a score of 5 because they are located at a distance and elevation from the 500 -year floodplain and were not likely to be flooded. Site 15 was assigned a score of 3 because it is located immediately adjacent to the Big Lost River and may be at least partially inundated during a 1,000-year flood. Sites 6, 9-13, 32, and 33 were assigned a score of 1 because they are located within the extent of pluvial Lake Terreton and would be subject to inundation during a future glacial cycle.

Table C-13. Floodplain criterion.

\begin{tabular}{ccl}
\hline Score & Sites & \multicolumn{1}{c}{ Scoring Rationale } \\
\hline 5 & $\begin{array}{c}2,3,4,5,7,8,14,16,17,18,19,20, \\
21,22,23,24,25,26,28,30,31,34\end{array}$ & $\begin{array}{l}\text { Located on the BLR floodplain, but outside the extent } \\
\text { of inundation from the 500-year or 1,000-year flood. }\end{array}$ \\
\hline 3 & 15 & $\begin{array}{l}\text { Located on the BLR floodplain and subject to partial } \\
\text { inundation from the 500- or 1,000-year flood. }\end{array}$ \\
\hline 1 & $6,9,10,11,12,13,32$, and 33 & Located within the boundaries of pluvial Lake Terreton. \\
\hline
\end{tabular}




\section{C-3.2 [30] Avoid Aquifer Recharge Areas}

Recharge to the SRPA occurs across the INL from the infiltration of rainfall and melted snowpack across the INL. However, this source of recharge is considered to be a small percentage of recharge to the aquifer. Recharge areas of significance on the INL include the channel of the Big Lost River, particularly a stream reach north of the NRF called the Big Lost River Sinks characterized by large infiltration losses, the INL spreading areas south of RWMC used for diversion of excess streamflows to protect downstream facilities, and terminal playas of the Big Lost River, Little Lost River, and Birch Creek. This criterion was not included in previous siting studies but is considered here because of the importance of aquifer protection. As described previously, protection of the SRPA from migrating radionuclides is an important consideration when siting a remote handled LLW disposal facility. If the containment structures of a facility located in a recharge zone were to fail, contaminants could be mobilized and could migrate to the aquifer. Thus, locations further from known SRPA recharge areas are preferable to closer locations. This criterion was determined to be of medium importance and was assigned a weighting factor of 3 (note that Land Use criteria are evaluated in Section C-4). 


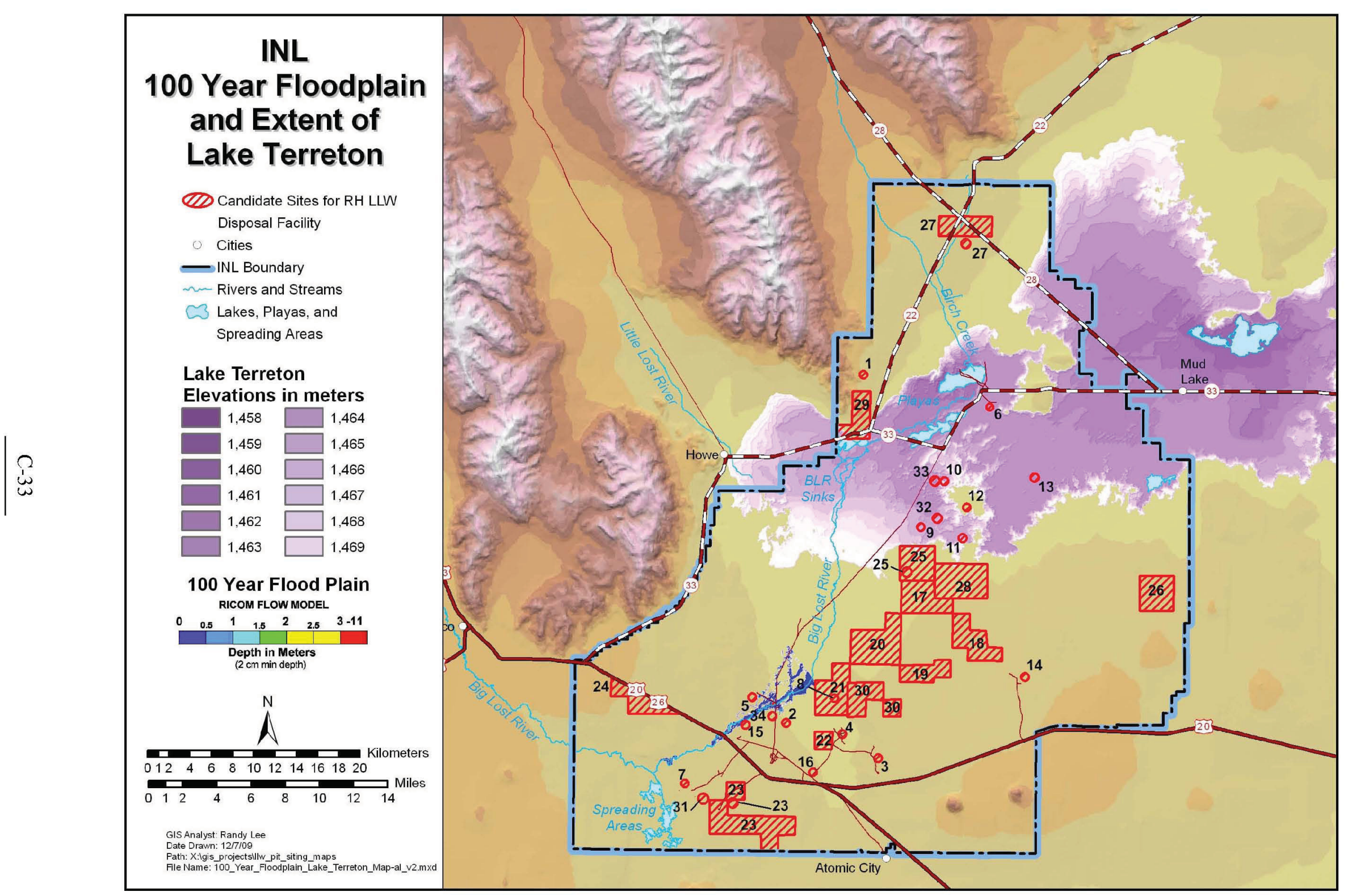

Figure C-7. 100-year floodplain and extent of pluvial Lake Terreton within the INL boundaries. 


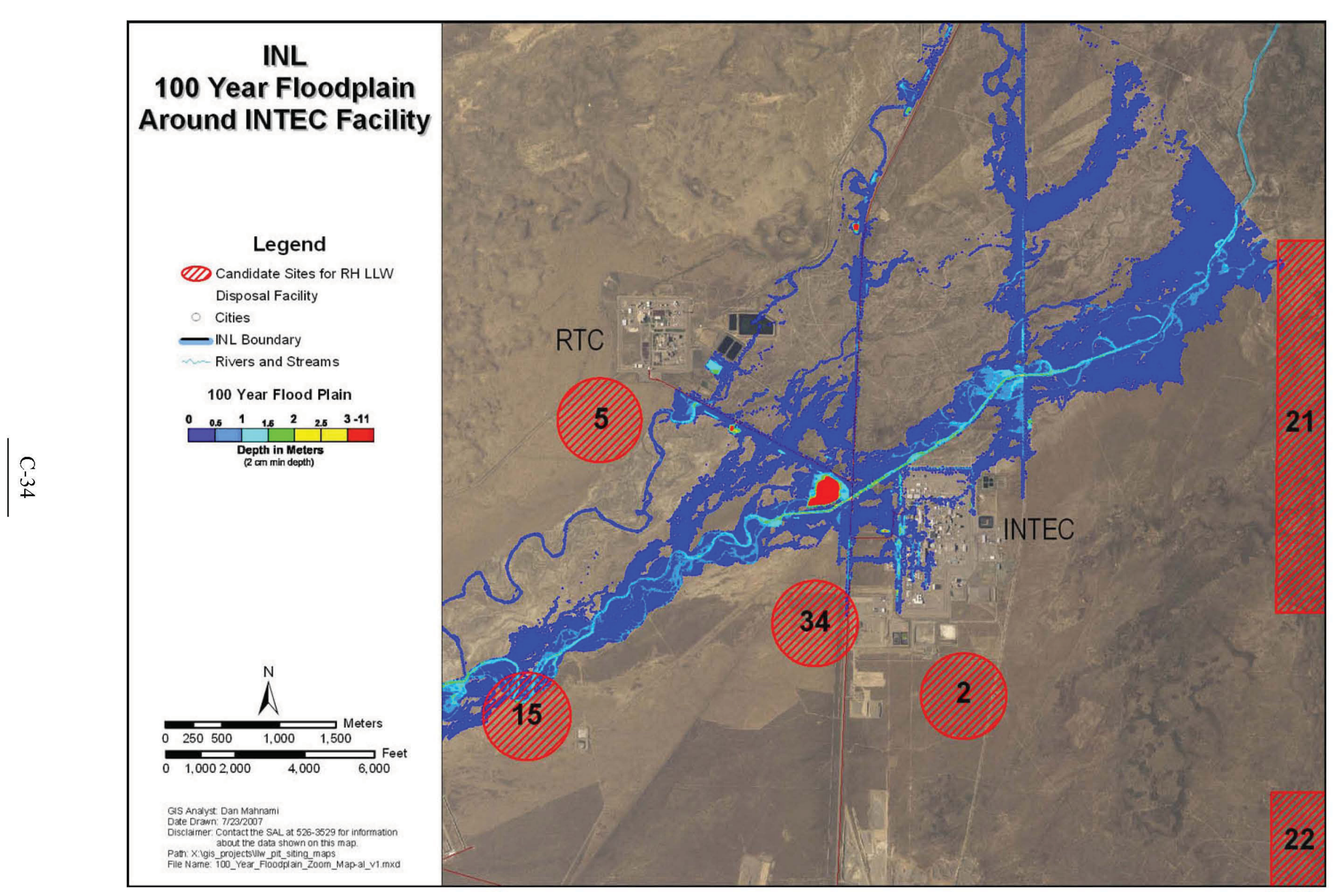

Figure C-8. 100-year floodplain around the Idaho Nuclear Technology and Engineering Center. 


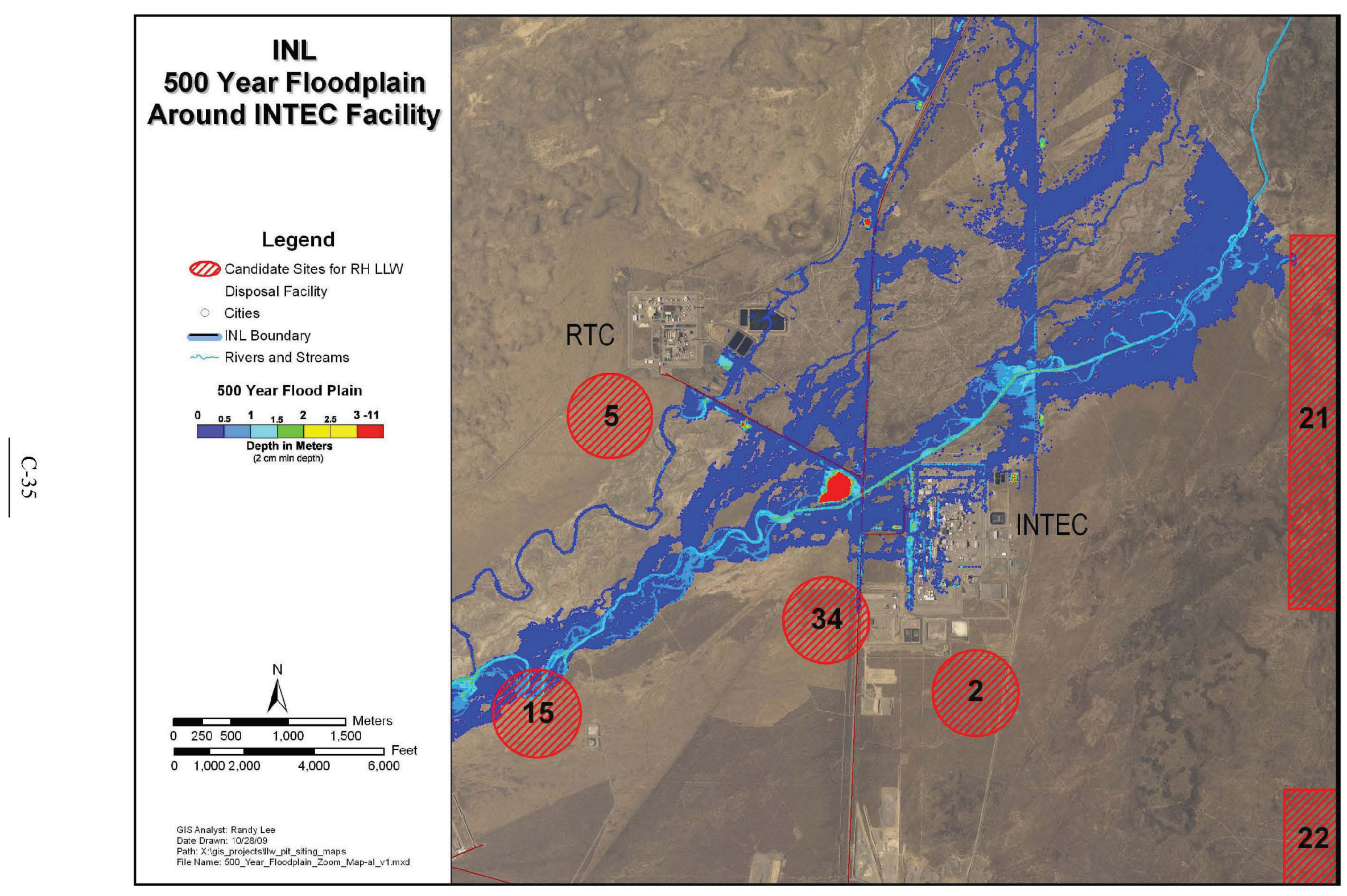

Figure C-9. 500-year floodplain around the Idaho Nuclear Technology and Engineering Center. 

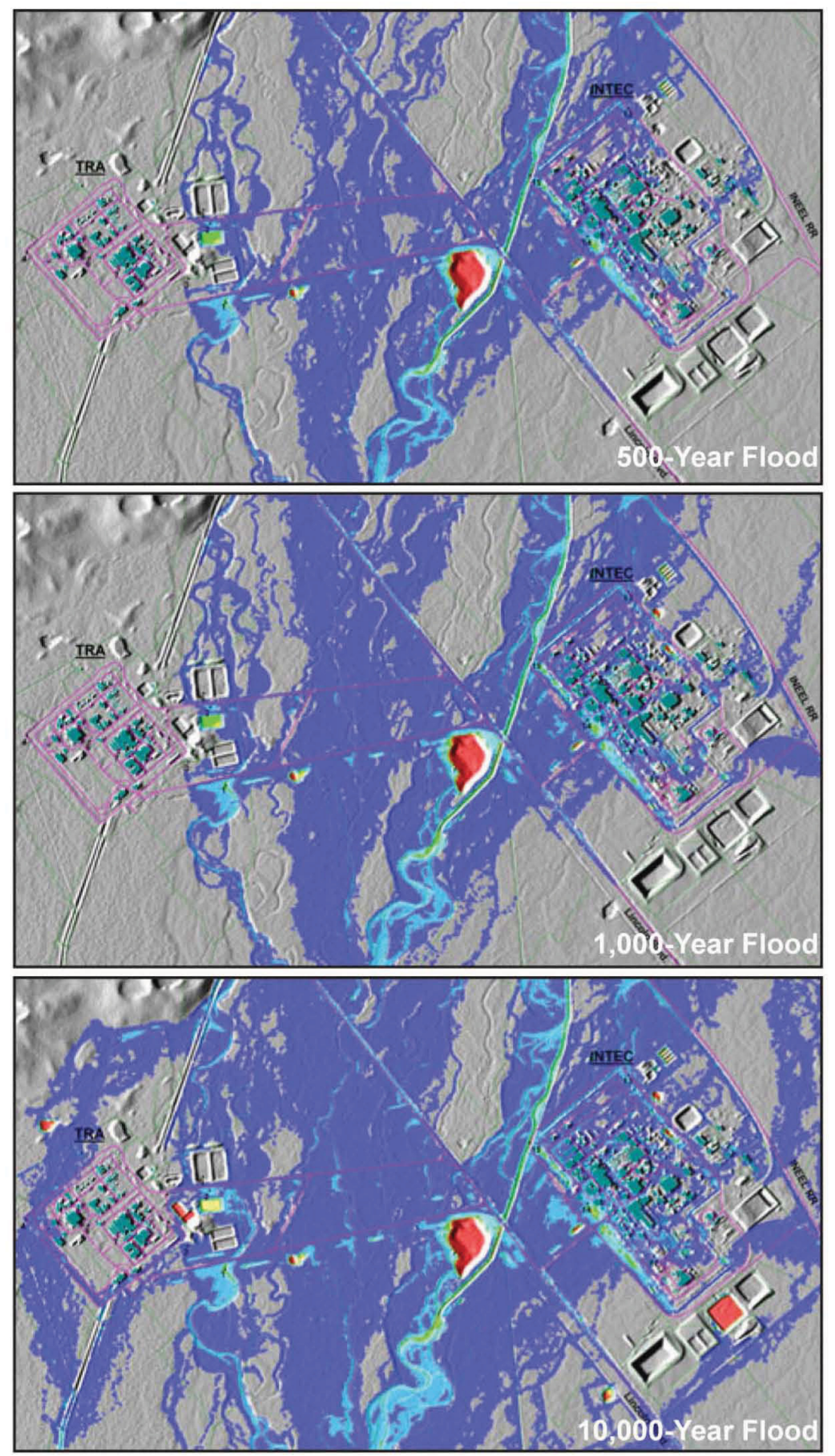

\section{Legend}
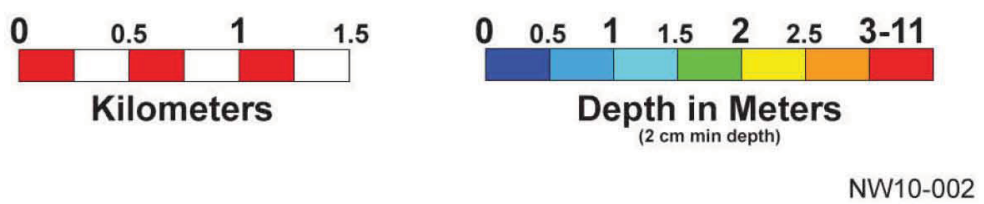

Figure C-10. Comparison of the estimated 500-, 1,000-, and 10,000-year floods (Ostenaa and O'Connell 2005). 
The aquifer recharge area criterion is based on proximity to the INL spreading areas, Big Lost River Sinks, and terminal playas to the Big Lost River, Little Lost River, and Birch Creek as identified on Figure C-11. For this criterion, a proposed facility located within or adjacent to an identified recharge area was assigned a score of 1 . A proposed facility located away from identified recharge areas was assigned a score of 5 .

Sites 2 through 6,8 through 26,28,30, and 32 through 34 are located at a sufficient distance from known aquifer recharge areas to preclude impacting those areas (Table $\mathrm{C}-14$ ). These sites were assigned scores of 5. Sites 7 and 31 are located in proximity to the INL spreading areas and could impact rapid recharge from flood flows into those areas.

Table C-14. Aquifer recharge area criterion.

\begin{tabular}{ccl}
\hline Score & Sites & \multicolumn{1}{c}{ Scoring Rationale } \\
\hline & $2,3,4,5,6,8,9,10,11,12,13$, & All sites are located at a sufficient distance from the INL \\
5 & $14,15,16,17,18,19,20,21$, & spreading areas, Big Lost River sinks, and terminal playas to \\
& $22,23,24,25,26,28,30,32$, & minimize potential for contaminant transport to the SRPA. \\
& NA & NA. \\
\hline 3 & 7,31 & Sites 7 and 31 are located directly adjacent to the INL \\
& spreading areas. \\
\hline
\end{tabular}

\section{C-3.3 [31] Avoid Areas of Surface Water Flooding or Ponding}

At the INL, rainfall on local snowpack and subsequent rapid snowmelt, when coupled with the low topographic relief, commonly results in local ponding and flooding that could compromise the performance of a LLW disposal facility. Sustained ponding and flooding can also result in conditions conducive to development of flow through the vadose zone. Generally speaking, a location with elevated topography and good surface-water drainage is preferable to a location with subdued topography and poor surface-water drainage. This criterion was determined to be of low importance and was assigned a weighting factor of 2 because facility design could be engineered to control drainage during the operational timeframe. To address longer timeframes, site-specific drainage characteristics can be chosen during facility design (e.g., moving site location to higher ground). In addition, the scoring factor addresses degree of adequate drainage in the general vicinity of a candidate site.

Topographic maps of the INL were used to evaluate topography and development of natural drainage systems that control the potential for surface water drainage at a specific site. The overall topography and drainage systems are shown on Figure C-12. Based on topographic contours as shown on USGS 7.5-minute quadrangle maps, a site with elevated surface topography and well-developed surfacewater drainage was assigned a score of 5 . A site with a moderately developed surface-water drainage was assigned a score of 3. A site identified as having potential for ponding or flooding was assigned a score of 1.

Sites 2 through 5, 8, 14, 17 through 22, 24 through 26, 28, and 34 are located in areas of well-developed surface drainage and were assigned scores of 5 . Sites $6,9,10,12,15,16$, and 30 through 33 are located in areas with moderately developed drainage and were assigned scores of 3 . Sites 7, 11, 13, and 23 are located in areas of poor drainage and were assigned scores of 1 . Table $\mathrm{C}-15$ provides the score and rationale for these sites. 


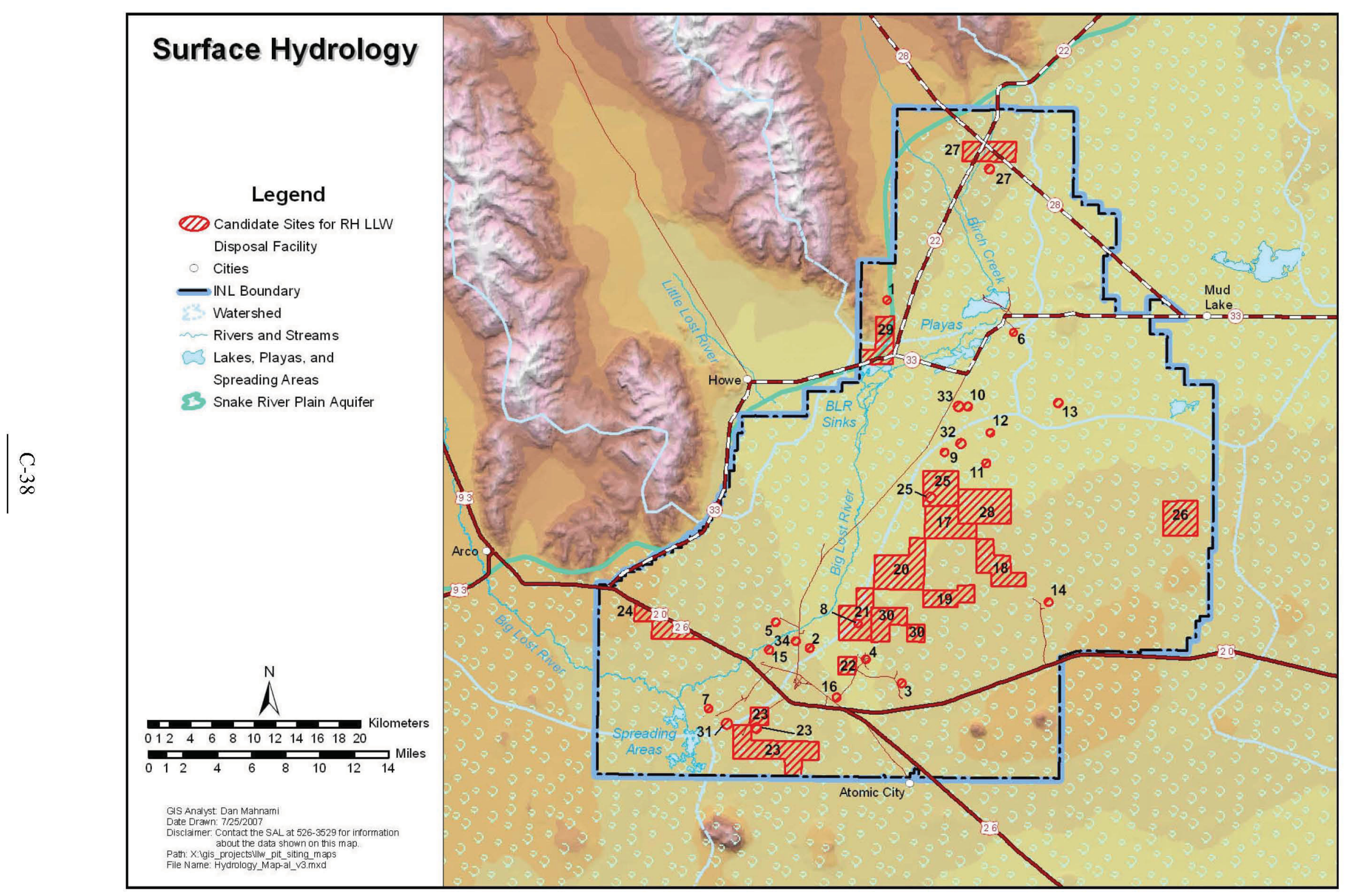

Figure C-11. Surface hydrology. 


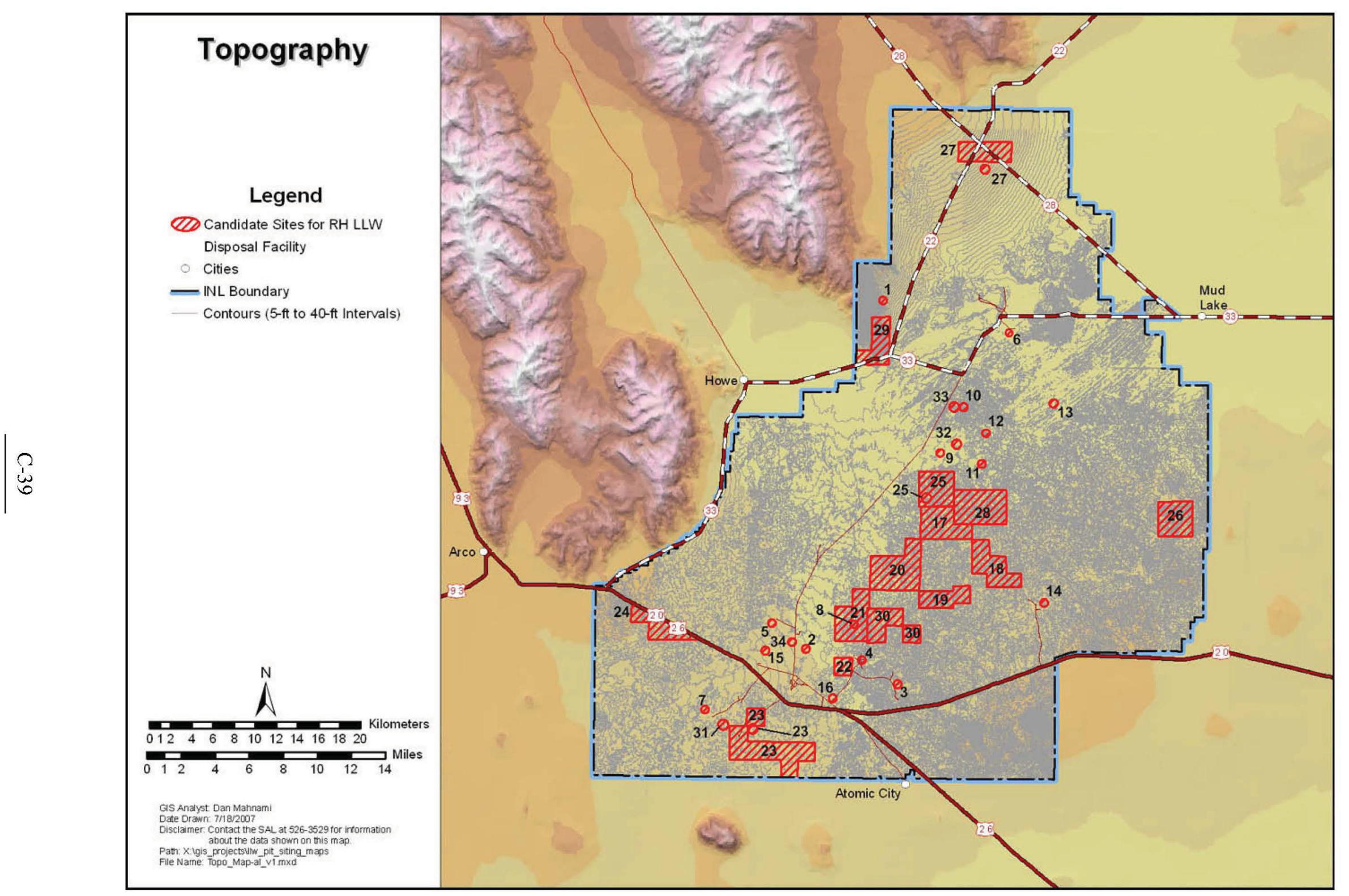

Figure C-12. Idaho National Laboratory topography. 
Table C-15. Surface water flooding/ponding criterion.

\begin{tabular}{ccl}
\hline Score & Sites & \multicolumn{1}{c}{ Scoring Rationale } \\
\hline 5 & $\begin{array}{c}2,3,4,5,8,14,17,18,19,20, \\
21,22,24,25,26,28,34\end{array}$ & $\begin{array}{l}\text { Sites are located in areas of elevated topographic relief and } \\
\text { well developed surface-water drainage systems. }\end{array}$ \\
\hline 3 & $6,9,10,12,15,16,30,31,32$, & $\begin{array}{l}\text { Sites are located in areas of moderately developed } \\
\text { surface-water drainage systems. }\end{array}$ \\
\hline 1 & $7,11,13,23$ & $\begin{array}{l}\text { Sites are located in areas of poorly developed surface-water } \\
\text { drainage systems. }\end{array}$ \\
\hline
\end{tabular}

\section{C-3.4 [32] Avoid Perched Water}

The presence of perched water near a permanent disposal facility indicates an active flow system through the vadose zone that can enhance the lateral and downward migration of contaminants in the subsurface. Sites located in areas with no perched water are desirable because groundwater flow in the vadose zone is minimized. Sites overlying perched water may be vulnerable to releases and contaminant transport through vadose zone flow. This criterion was determined to be of low importance and was assigned a weighting factor of 2 because areas of natural perched water are limited in extent and areas of anthropogenic perched water are diminishing as a result of changes in management practice.

At the INL, perched water is most likely to occur beneath wastewater infiltration or percolation ponds, beneath major waterways, and under the spreading area diversions near the RWMC. Previous characterization studies have defined the areal extent of perched water beneath infiltration ponds and other features at INTEC and ATR. However, these zones have been decreasing in thickness and areal extent since use of infiltration ponds has been discontinued. Based on proximity to the Big Lost River and the INL spreading areas (Figure C-11), a site located in an area distant from known or suspected perched water was assigned a score of 5 . A site in proximity to perched water was assigned a score of 3 . A site located in an area with known perched water was assigned a score of 1 .

Sites $3,4,6,8$ through 14,16 through 22,24 through $26,28,30,32$, and 33 are located in areas away from identified perched groundwater bodies (Table C-16). Sites 2, 5, 7, 23, 31, and 34 are located near perched water. Site 15 is located adjacent to the Big Lost River in an area where perched groundwater bodies routinely develop in response to recharge from streamflows.

Table C-16. Perched water criterion.

\begin{tabular}{ccl}
\hline Score & Sites & \multicolumn{1}{c}{ Scoring Rationale } \\
\hline 5 & $\begin{array}{c}3,4,6,8,9,10,11,12,13,14,16,17,18, \\
19,20,21,22,24,25,26,28,30,32,33\end{array}$ & Sites are located away from perched groundwater. \\
\hline 3 & $2,5,7,23,31,34$ & $\begin{array}{l}\text { Sites are located in proximity to perched } \\
\text { groundwater. }\end{array}$ \\
\hline 1 & 15 & $\begin{array}{l}\text { Site is located adjacent to the Big Lost River in an } \\
\text { area of identified perched groundwater. }\end{array}$ \\
\hline
\end{tabular}




\section{C-3.5 [33] Avoid Wellhead Protection Areas}

Consideration of site location with regard to wellhead protection areas was not identified in any of the previous studies. It is not a requirement that a new LLW disposal facility location be outside a wellhead protection area, but it is considered useful information for the siting process and consequently it was retained for evaluation. The wellhead protection areas include the immediate vicinity of a production well and the area upgradient where groundwater would be derived from production wells. This criterion was determined to be of medium importance and was assigned a weighting factor of 3 because protection of facility water supply is desirable; however, mitigation can be accomplished through monitoring and development of new water supply sources.

Clearly delineated wellhead protection areas (Sehlke 2003) were defined as part of a voluntary wellhead protection program to include those areas located hydraulically upgradient from production wells. The protection areas were zoned to include areas immediately adjacent to wells where short groundwater travel times would preclude mitigation and areas farther upgradient where travel times would permit mitigation. The Performance Assessment (PA) will include modeling studies that can be used to refine travel time estimates.

Figure C-13 delineates wellhead protection areas, including those areas for TAN, NRF, INTEC, Central Facilities Area, ATR, Rifle Range, main gate, RWMC, and MFC wells. Those sites outside delineated wellhead protection areas were assigned scores of 5 . Those sites within wellhead protection areas but considered to be sufficiently upgradient from production wells to mitigation could be accomplished through monitoring and construction of new production wells were assigned scores of 3 . Those sites within wellhead protection areas and where travel time was considered to be insufficient to mitigate contaminant releases were assigned a score of 1 .

Sites 2, 3, 6 through 13, 17 through 19, 21 through 26,28, and 30 through 34 are located outside of wellhead protection areas and were assigned scores of 5 (Table C-17). Sites 4, 5, 15, and 20 are located within wellhead protection areas but are sufficiently distant from production wells to ensure adequate travel time and permit mitigation. Sites 14 and 16 are located within wellhead protection areas and travel times from these sites to downgradient production wells are considered to be too short to mitigate possible contaminant releases to the subsurface.

Table C-17. Wellhead protection criterion.

\begin{tabular}{ccl}
\hline Score & Sites & \multicolumn{1}{c}{ Scoring Rationale } \\
\hline 5 & $\begin{array}{l}2,3,6,7,8,9,10,11,12,13,17,18,19, \\
21,22,23,24,25,26,28,30,31,32,33, \\
34\end{array}$ & $\begin{array}{l}\text { Sites are located outside of wellhead protection } \\
\text { areas. }\end{array}$ \\
\hline 3 & $4,5,15,20$ & $\begin{array}{l}\text { Sites are located within wellhead protection areas } \\
\text { but with travel times sufficient to permit mitigation. }\end{array}$ \\
\hline 1 & 14,16 & $\begin{array}{l}\text { Sites are located within wellhead protection areas } \\
\text { and too close to production wells to mitigate. }\end{array}$ \\
\hline
\end{tabular}




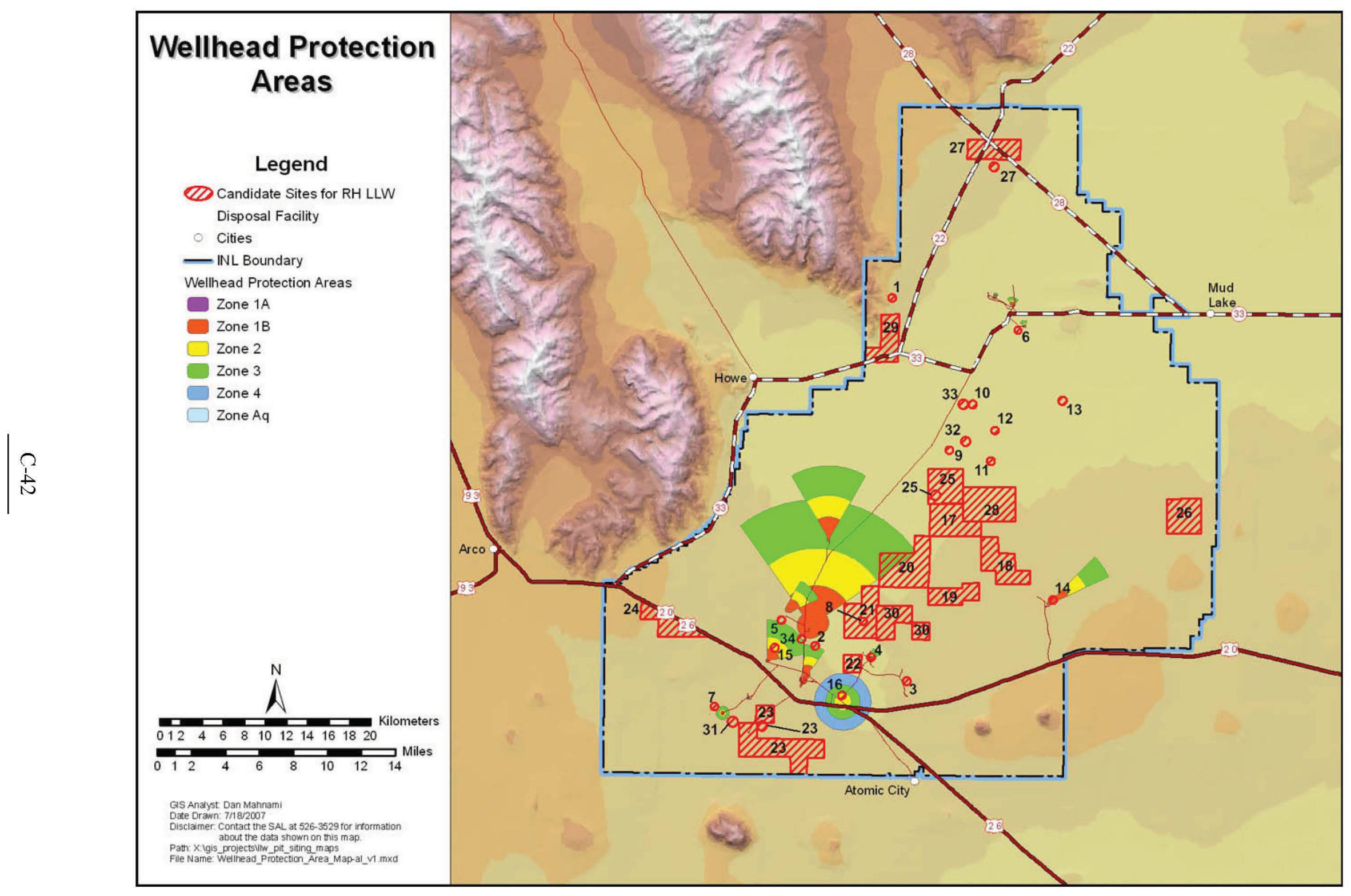

Figure C-13. Wellhead protection area. 


\section{C-4. LAND USE}

The proposed LLW disposal facility sites that were determined to be satisfactory or conditionally satisfactory with respect to the "Must" criteria were further evaluated on the basis of four identified "Want" criteria in the land-use category. These criteria consist of:

1. Location within the core infrastructure area

2. Avoidance of the Explosives Test Area

3. Location near transportation and utilities

4. Avoidance of industrial and controlled areas.

\section{C-4.1 [37] Located Within Core Infrastructure Area}

New INL development is expected to take place within the existing Core Infrastructure Area as identified in the 30-year land use scenario map constructed by Kostelnik (2005). The core infrastructure area criterion was considered to be of high importance and was assigned a weighting factor of 4 because of the requirement to be consistent with INL future land-use plans and to avoid areas that have been identified for future development or set aside for other purposes. Also, accomplishment of the INL mission is intimately connected to current and future land use.

Figure $\mathrm{C}-14$ delineates the Core Infrastructure Area and possible transportation corridor as derived from the 30-year land use scenario map (Kostelnik 2005). This map was used to evaluate potential LLW sites for the core infrastructure area criterion. Those sites within the delineated Core Infrastructure Area were assigned scores of 5 . Those sites located outside the Core Infrastructure Area were assigned scores of 1 .

Sites 2 through 12, 14 through 22, 25, 28, and 30 through 34 are located within the Core Infrastructure Area (Table C-17). These sites were assigned scores of 5. Sites 13, 23, 24, and 26 are located outside the Core Infrastructure Area and were assigned scores of 1.

Table C-17. Core infrastructure criterion.

\begin{tabular}{ccl}
\hline Score & \multicolumn{1}{c}{ Sites } & \multicolumn{1}{c}{ Scoring Rationale } \\
\hline 5 & $2,3,4,5,6,7,8,9,10,11,12,14,15,16,17,18,19$, & $\begin{array}{l}\text { Sites located within the Core } \\
\text { Infrastructure Area. }\end{array}$ \\
\hline 3 & $20,21,22,25,28,30,31,32,33,34$ & NA. \\
\hline 1 & NA & $\begin{array}{l}\text { Sites located outside the Core } \\
\text { Infrastructure Area. }\end{array}$ \\
\hline
\end{tabular}




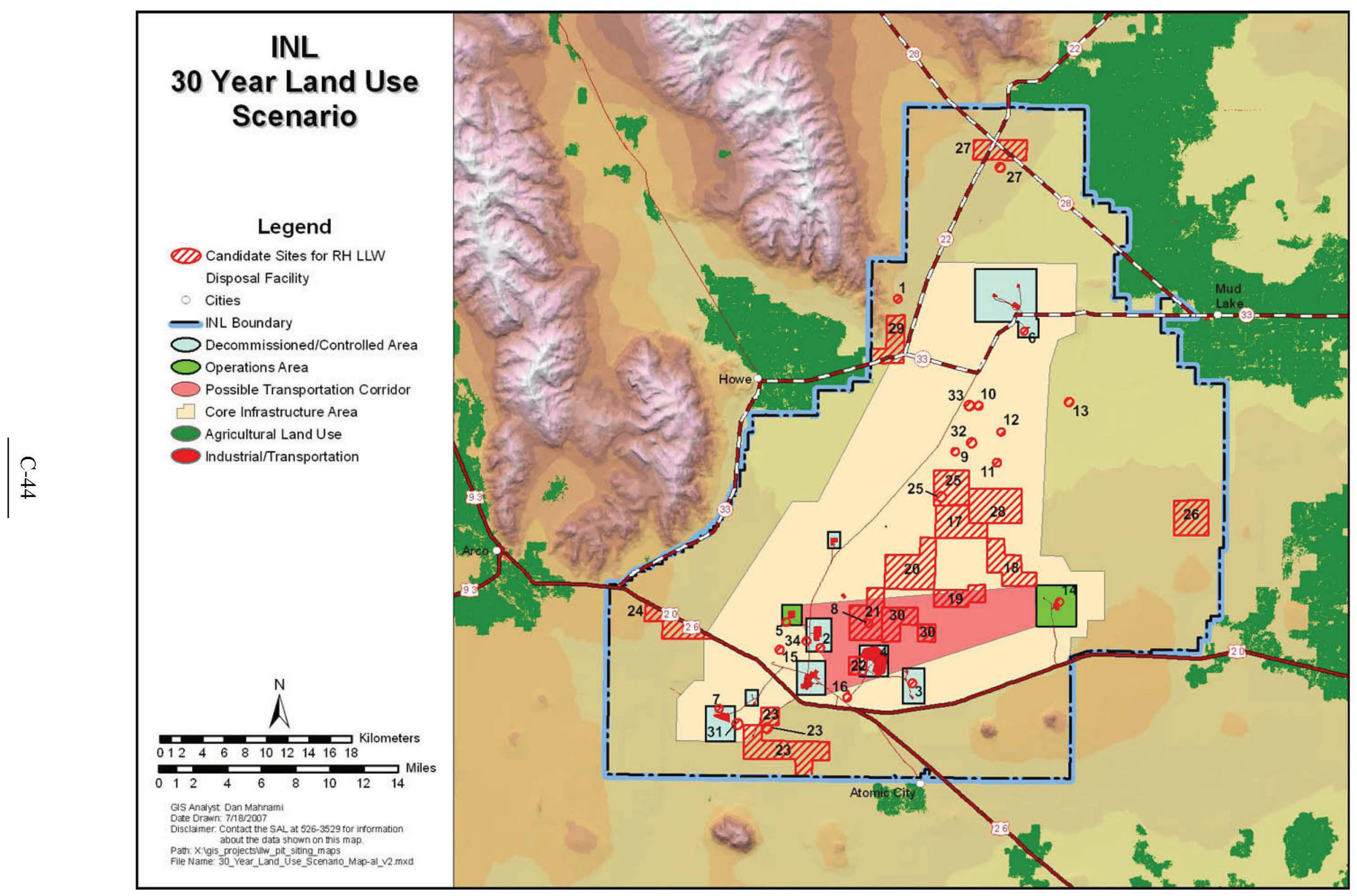

Figure C-14. 30-year land use scenario. 


\section{C-4.2 [38] Avoid the Explosives Test Area}

The Explosives Test Area and buffer zone are planned for construction as part of current and future INL land-use plans. Testing will be conducted at this facility to analyze the effects of explosives, munitions, and similar items on security systems, vehicles, structures, and other materials. Testing will occur intermittently on a planned basis, and activities can be avoided during testing. This criterion is considered to be of very high importance and was assigned a weighting factor of 5 because of the importance of conforming to current and future INL land-use plans and because of safety considerations associated with testing explosives.

Scoring of this criterion was based on Figure C-15, a map showing the location of the Explosives Test Area and a surrounding buffer. This map shows the location of the Explosives Test Area, consisting of a 2-mi radius closure zone, 5-mi safety fan, and a 5-mi radius denoting a buffer zone. Potential sites that were located outside of the buffer zone were assigned a score of 5 . Sites located within the 5 -mi radius buffer zone but outside the closure zone were assigned a score of 3 . Sites within the 2-mi closure zone and the safety fan were assigned a score of 1 .

Figure C-15 also denotes the location of INL rifle range fans with respect to candidate remote-handled LLW disposal sites. No sites were located within the rifle range fans and, while they were not used as a discriminator, locating a new facility within the range boundaries should definitely be avoided. Figure $\mathrm{C}-16$ shows the location of INL ordnance areas. This criterion, although important, does not easily lend itself to a ranking strategy and was not used in this evaluation. However, as indicated on this figure, most sites are located within or near assessed, uncleared, and downrange ordnance areas and would require a site-specific ordnance assessment prior to construction.

Sites 2 through $8,16,19$ through $24,26,30,31$, and 34 were located outside of the buffer zone and were assigned scores of 5 . Sites 9,10, 12 through 15, 17, 25,32, and 33 were located within the buffer zone but outside the safety fan and were assigned scores of 3 . Sites 11 and 28 were within the closure zone and Site 18 was within the safety fan. These sites were assigned scores of 1 . Table C-18 provides the score and rationale for these sites.

Table C-18. Explosives test area criterion.

\begin{tabular}{ccl}
\hline Score & \multicolumn{1}{c}{ Sites } & \multicolumn{1}{c}{ Scoring Rationale } \\
\hline 5 & $2,3,4,5,6,7,8,16,19,20,21,22$, & $\begin{array}{l}\text { Sites are located outside the closure zone, safety fan, and } \\
\text { buffer zone. }\end{array}$ \\
\hline 3 & $9,10,12,13,14,15,17,25,32,33$ & $\begin{array}{l}\text { Sites are located within the buffer zone, but outside the } \\
\text { safety fan. }\end{array}$ \\
\hline 1 & $11,18,28$ & $\begin{array}{l}\text { Sites 11 and 28 are located within the closure zone. Site } \\
18 \text { is located within the safety fan. }\end{array}$ \\
\hline
\end{tabular}




\section{C-4.3 [39] Near Utilities and Transportation}

Site construction, operation, and maintenance require availability of utilities and transportation routes. Existing utilities and transportation routes are preferable because construction of new infrastructure is costly, and their use eliminates potential secondary impacts resulting from new utility and roadway construction. This criterion was considered to be of high importance and was assigned a weighting factor of 4 because of the desirability of elimination secondary or offsite impacts and because of significant expense associated with road and utility construction. 


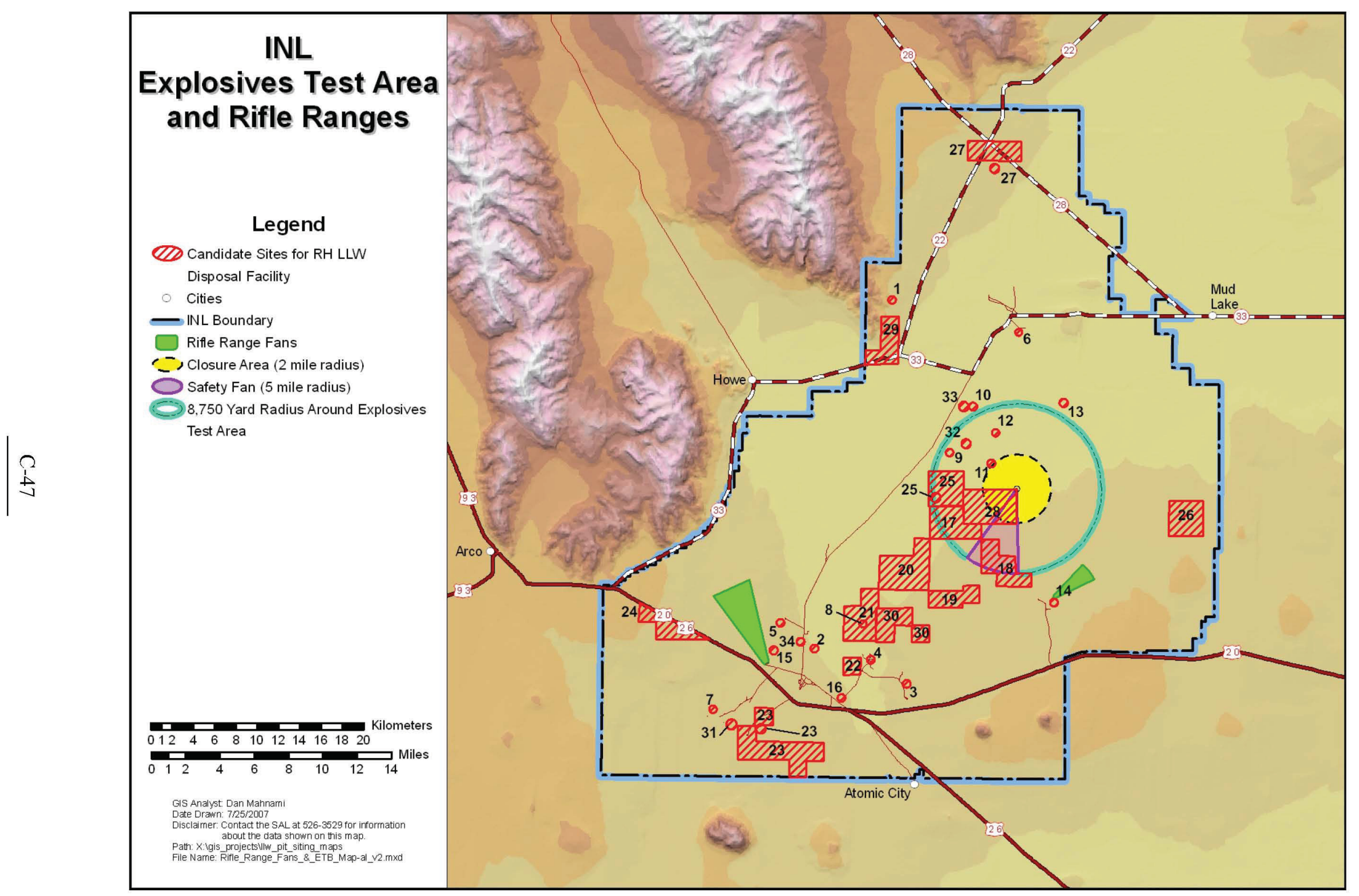

Figure C-15. Explosives Test Area and rifle ranges. 


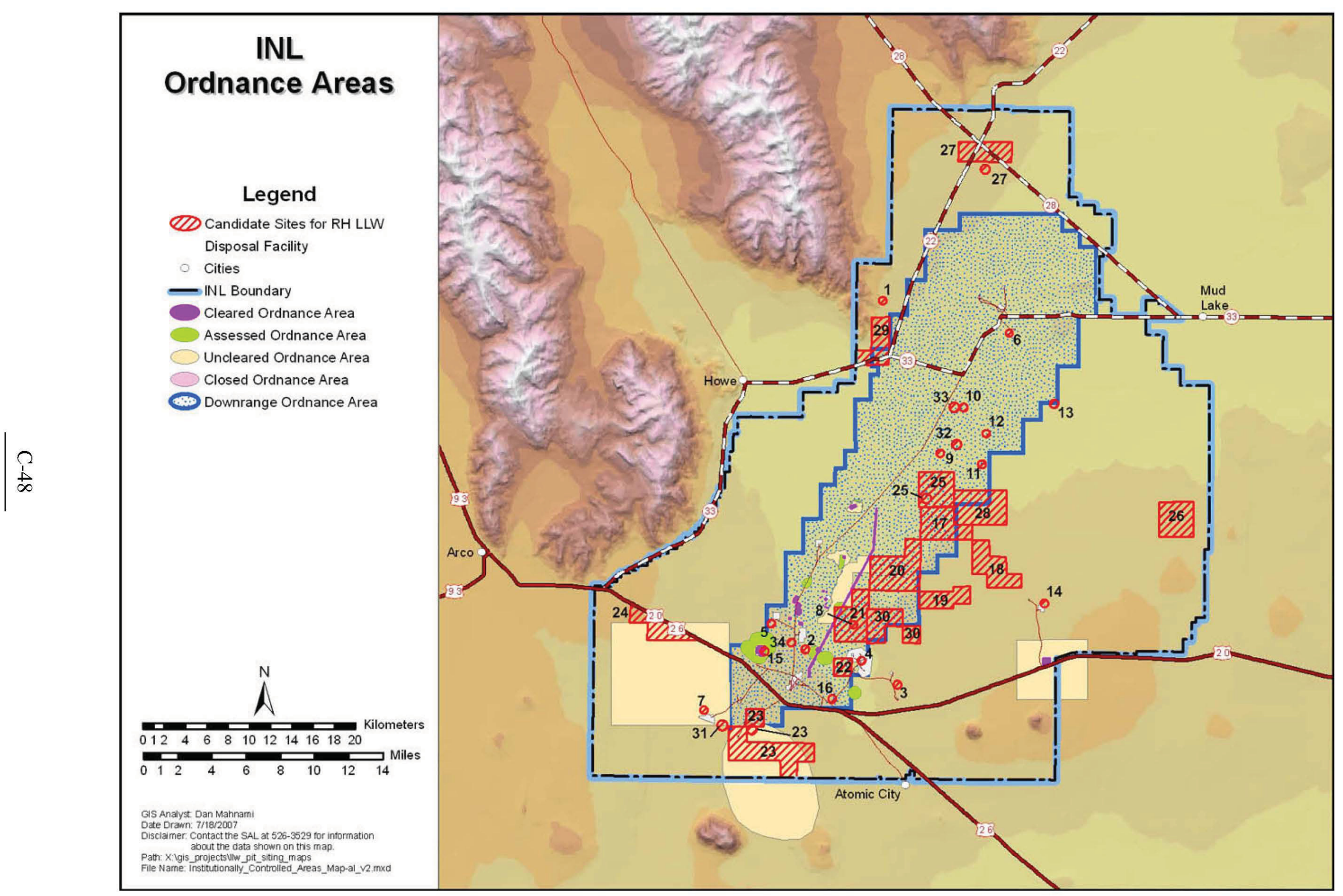

Figure C-16. Ordnance areas. 
Figure C-17 delineates areas within $1 \mathrm{mi}$ of existing roads and power lines. Sites that were located within $0.5 \mathrm{mi}$ of utility corridors were assigned a score of 5 . Sites within $1 \mathrm{mi}$ of these corridors were assigned a score of 3 . Sites located at distances greater than $1 \mathrm{mi}$ were assigned a score of 1 .

Sites 2 through $6,14,16,22,24,33$, and 34 are located within $0.5 \mathrm{mi}$ of utilities and transportation corridors and were assigned scores of 5. Sites 7 through 10,15,21,23, and 31 are located within 1 mi of corridors and were assigned scores of 3 . Sites 11 through 13, 17 through 20,25, 26, 28, 30, and 32 are located more than $1 \mathrm{mi}$ from corridors and were assigned scores of 1 . Table $\mathrm{C}-19$ provides the score and rationale for these sites.

Table C-19. Utilities and transportation criterion.

\begin{tabular}{ccl}
\hline Score & Sites & \multicolumn{1}{c}{ Scoring Rationale } \\
\hline 5 & $2,3,4,5,6,14,16,22,24,33$, & $\begin{array}{l}\text { Sites are located within a } 0.5 \text { mi distance of existing utility } \\
\text { lines and roads. }\end{array}$ \\
\hline 3 & $7,8,9,10,15,21,23,31$ & $\begin{array}{l}\text { Sites are located at a distance between } 0.5 \text { and } 1 \mathrm{mi} \text { of } \\
\text { existing utility lines and roads. }\end{array}$ \\
\hline & $11,12,13,17,18,19,20,25$, & $\begin{array}{l}\text { Sites are located at a distance greater than } 1 \text { mi from existing } \\
\text { utility lines and roads. }\end{array}$ \\
\hline
\end{tabular}

\section{C-4.4 [40] Avoid Industrial and Controlled Areas}

Location of a new facility requires coordination with existing industrial and controlled areas at the INL. This criterion is included to conform to current and future INL land-use plans. Industrial areas include the footprint of existing INL facilities. Institutionally controlled areas are areas where hazards remain, thus precluding release of these sites for unrestricted use. Specific to siting LLW disposal facilities, these areas consist of INL facilities and associated Waste Area Groups (WAGs). Location of a LLW site outside of the footprint of existing INL facilities (industrial areas) and WAGs 1 through 9 (institutionally controlled areas) is consistent with INL land-use plans. This criterion is considered to be of very low importance and is assigned a weighting factor of 1 because the extent of industrial and controlled areas is limited and within the controlled areas mitigation is possible.

Figure C-14 shows the location of industrial sites and controlled areas. Sites located outside identified industrial or controlled areas were assigned a score of 5, sites within or near a controlled area were assigned a score of 3 , and sites within an industrial area where were assigned a score of 1 .

Sites 8 through 13, 15 through 21,23 through 26, 28, 30,32, and 33 are located outside identified industrial or controlled areas and were assigned scores of 5 . Sites 2, 3, 5 through 7, 14, 22, 31, and 34 are located within industrial or controlled areas, but sites can be mitigated. These sites were assigned scores of 3 (Table C-20). One site was within industrial or controlled areas where mitigation was not possible. 
Table C-20. Industrial and controlled areas criterion.

\begin{tabular}{ccl}
\hline Score & \multicolumn{1}{c}{ Sites } & \multicolumn{1}{c}{ Scoring Rationale } \\
\hline 5 & $8,9,10,11,12,13,15,16,17,18,19$, & $\begin{array}{l}\text { All sites are unambiguously outside industrial or } \\
\text { controlled areas. }\end{array}$ \\
\hline 3 & $20,21,23,24,25,26,28,30,32,33$ & Nine sites are within controlled areas. \\
\hline 1 & $2,3,5,6,7,14,22,31,34$ & $\begin{array}{l}\text { One site is within an industrial area, no mitigation } \\
\text { possible. }\end{array}$ \\
\hline
\end{tabular}




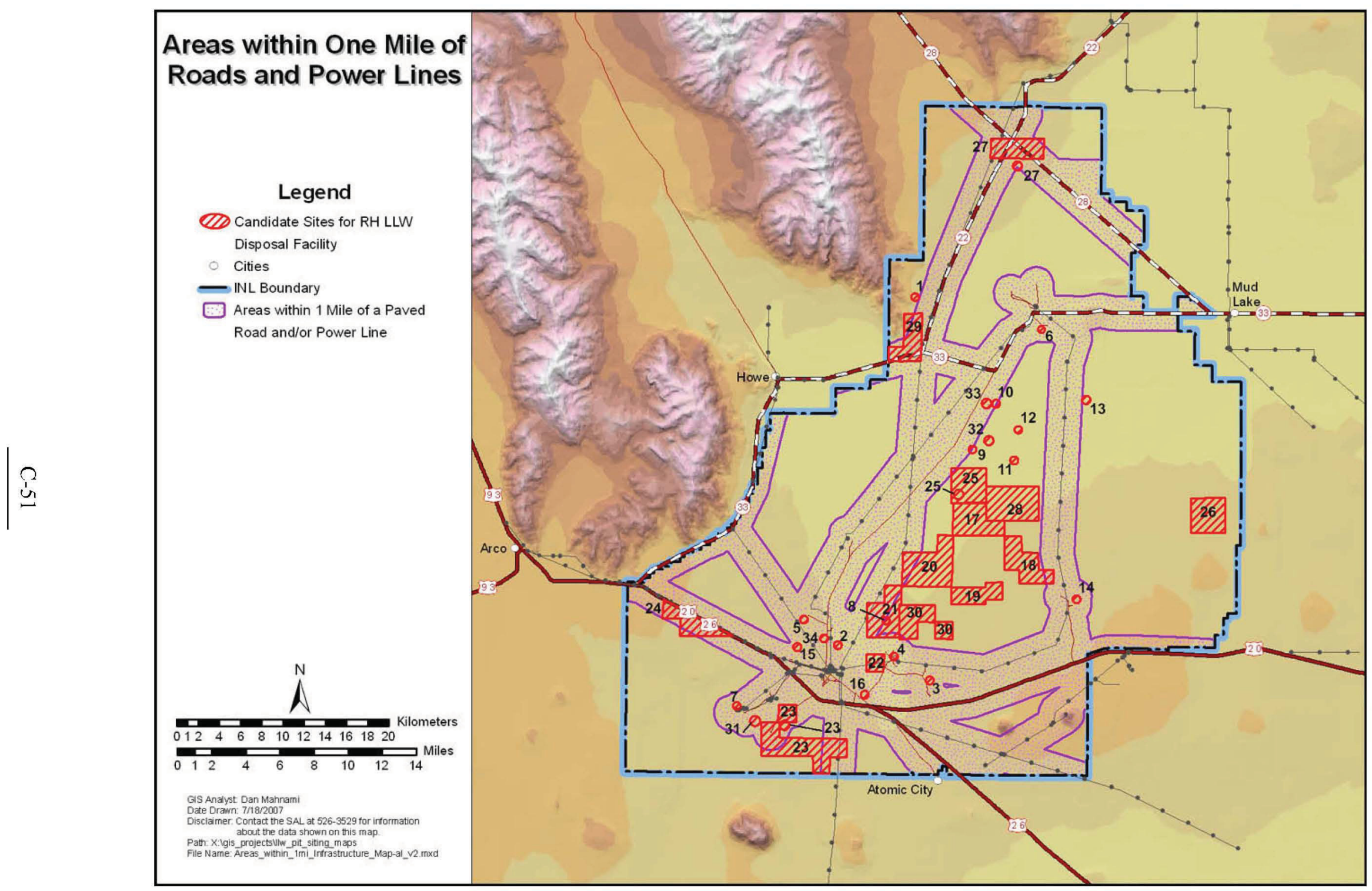

Figure C-17. Areas within 1 mi of roads and power lines. 


\section{C-5. NATURAL RESOURCES}

The proposed LLW disposal facility sites that were determined to be satisfactory or conditionally satisfactory with respect to the "Must" criteria were further evaluated on the basis of three selected natural resource "Want" criteria. These criteria consist of:

1. Avoidance of the Sagebrush-Steppe Ecosystem Reserve

2. Avoidance of vegetation transects

3. Avoidance of critical habitat.

\section{C-5.1 [47] Avoid the Sagebrush-Steppe Ecological Reserve}

The INL lies within the sagebrush-steppe region of North America. The sagebrush-steppe is a critically endangered ecosystem characterized by dry habitat dominated by various species of sagebrush and other shrubs, short grasses, and forbs. Within INL, 72,263 acres has been designated as the Sagebrush-Steppe Ecosystem Reserve with special management obligations that include wildfire suppression, livestock grazing, road management, weed control, and protection of cultural resources (BLM 2004). This criterion is considered to be of high importance and is assigned a weighting factor of 4 because of the unique nature of the Sagebrush-Steppe Ecosystem Reserve and the importance of protecting its biodiversity.

Figure C-18 delineates INL ecological land use areas, including the Sagebrush-Steppe Ecosystem Reserve. Based on this map, sites located outside the Sagebrush-Steppe Ecosystem Reserve are assigned a score of 5 and sites within the Sagebrush-Steppe Ecosystem Reserve are assigned a score of 1 . Sites 2 through 5, 7 through 9, 11, 13 through 26,28, 30 through 32, and 34 are located outside the boundary of the Sagebrush-Steppe Ecosystem Reserve and were assigned scores of 5 (Table C-21). Sites 6, 10, 12, and 33 are located within the Sagebrush-Steppe Ecosystem Reserve and were assigned a score of 1 .

Table C-21. Sagebrush-Steppe Ecosystem Reserve criterion.

\begin{tabular}{ccl}
\hline Score & \multicolumn{1}{c}{ Sites } & \multicolumn{1}{c}{ Scoring Rationale } \\
\hline 5 & $\begin{array}{c}2,3,4,5,7,8,9,11,13,14,15,16,17,18, \\
19,20,21,22,23,24,25,26,28,30,31, \\
32,34\end{array}$ & $\begin{array}{l}\text { Sites are located outside the boundary of the } \\
\text { Sagebrush-Steppe Ecosystem Reserve. }\end{array}$ \\
\hline 3 & NA & NA. \\
\hline 1 & $6,10,12,33$ & $\begin{array}{l}\text { Sites 6, 10, 12, and 33 are located within the } \\
\text { boundary of the Sagebrush-Steppe Ecosystem } \\
\text { Reserve. }\end{array}$ \\
\hline
\end{tabular}

\section{C-5.2 [48] Avoid Vegetation Transects}

Two vegetation transects are located on the INL (Figure C-19). Data from these transects have been collected for about 30 years to monitor long-term changes in vegetation in an undisturbed setting. Because of the unique datasets provided by these transects, it is undesirable to locate a facility within the transect boundaries; however, mitigation may be possible for sites near the edges (e.g., move site location). This criterion is considered to be of medium importance and is assigned a weighting factor of 3. 


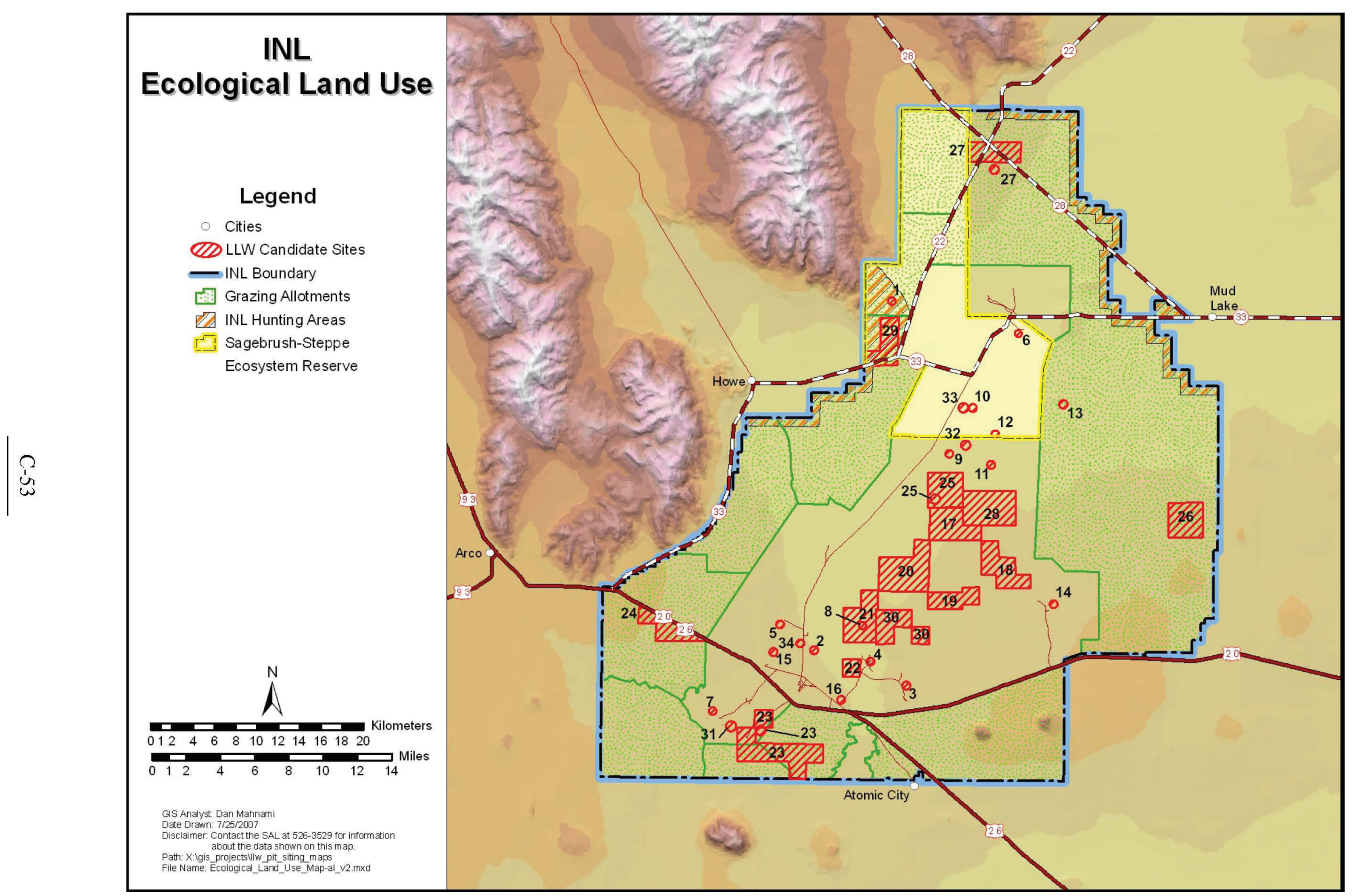

Figure C-18. Ecological land use. 


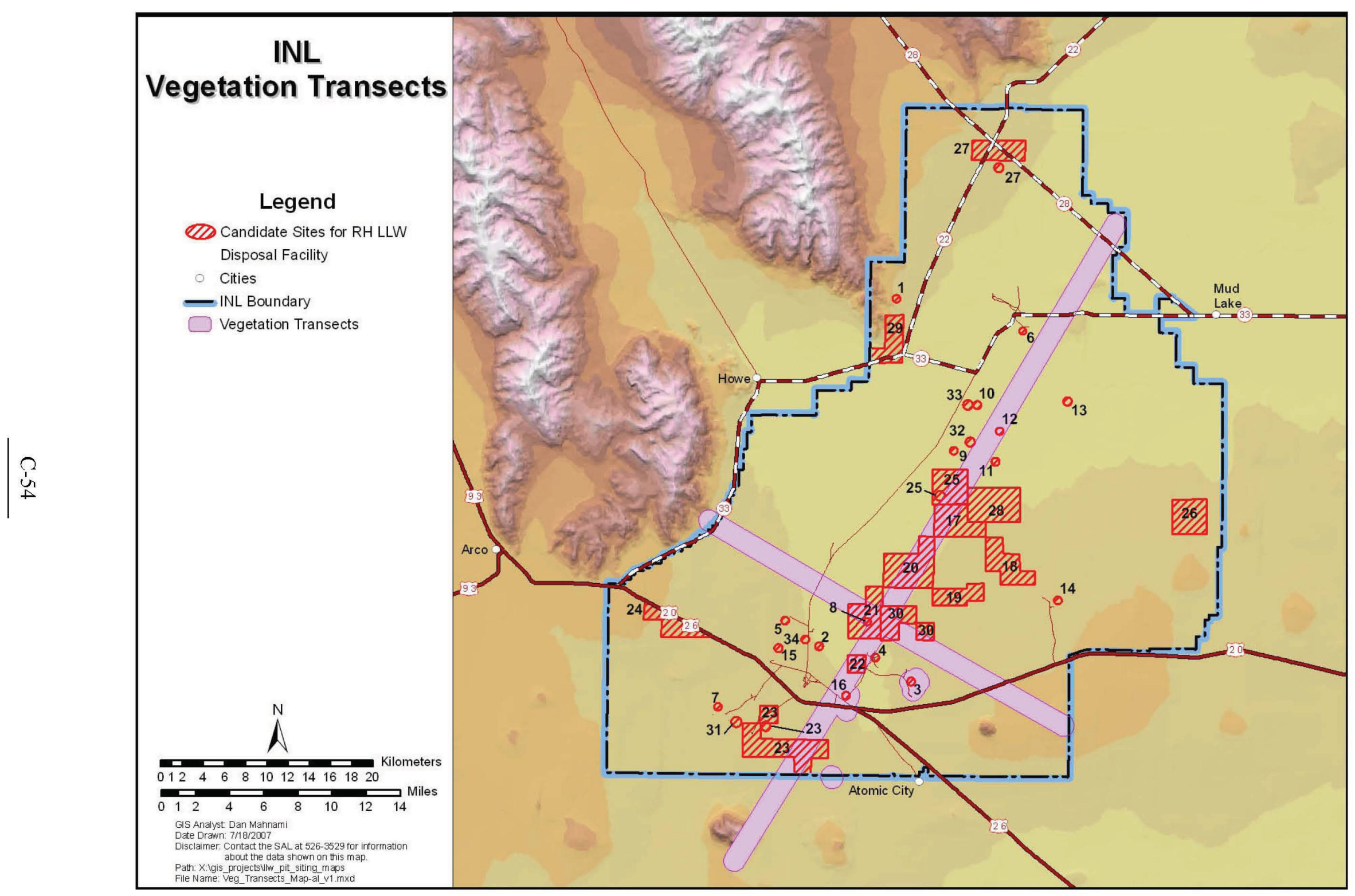

Figure C-19. Vegetation transects. 
Figure C-19 delineates the location of the two vegetation transects. Sites outside these transects were assigned a score of 5. Sites near boundaries of the transects where effects of facility construction and maintenance may be mitigated were assigned a score of 3 and sites within the transects were assigned scores of 1 .

Sites 2, 5 through 7, 9, 10, 13 through $15,18,19,24,26,28$, and 31 through 34 are located outside INL vegetation transects and are assigned scores of 5 (Table C-22). Sites 4, 11, and 23 are located within the transects. Sites 4 and 11 are located on the margins of the northeast trending transect and their impact on transect data acquisition is minimal so these sites were assigned scores of 3 . Similarly, site 23 was assigned a score of 3 because this site is sufficiently large that the criterion can be mitigated by locating the site away from the transect. Sites $3,8,12,16,17,20$ through 22,25 , and 30 are assigned a score of 1 because they all are located within the transects and their impact on data acquisition cannot be mitigated.

Table C-22. Vegetation transects criterion.

\begin{tabular}{|c|c|c|}
\hline Score & Sites & Scoring Rationale \\
\hline 5 & $\begin{array}{l}2,5,6,7,9,10,13,14 \\
15,18,19,24,26,28 \\
\quad 31,32,33,34\end{array}$ & Located outside of INL vegetation transects. \\
\hline 3 & $4,11,23$ & $\begin{array}{l}\text { Sites } 4 \text { and } 11 \text { located on transect margins and will minimally } \\
\text { impact data acquisition. Site } 23 \text { is sufficiently large to permit } \\
\text { selection of a site away from the transect. }\end{array}$ \\
\hline 1 & $\begin{array}{c}3,8,12,16,17,20,21 \\
22,25,30\end{array}$ & $\begin{array}{l}\text { Located inside of INL vegetation transects where attempts at } \\
\text { mitigation are deemed undesirable. }\end{array}$ \\
\hline
\end{tabular}

\section{C-5.3 [49] Avoid Ecologically Sensitive Species and Habitat}

Location of sites where ecologically sensitive species and habitat could be affected is considered to be undesirable. This criterion is considered to be of high importance and is assigned a weighting factor of 4. The final site evaluation "Want" criteria list included consideration of sensitive habitat as defined by the State of Idaho Species of Greatest Conservation Need (including wildlife species identified in the Comprehensive Wildlife Conservation Strategy (IDFG 2005), and Bureau of Land Management (BLM) special status species. These species are ranked by the state and are defined as follows:

- G: Global rank indicator; denotes rank based on range-wide status

- $\quad$ S: State rank indicator; denotes rank based on status within Idaho

- 1: Critically imperiled because of extreme rarity or because some factor of its biology makes it particularly vulnerable to extinction (typically five or fewer occurrences)

- 2: Imperiled because of rarity or because other factors demonstrably make it very vulnerable to extinction (typically six to 20 occurrences)

- 3: Rare or uncommon but not imperiled (typically 21 to 100 occurrences)

- 4: Not rare and apparently secure, but with cause for long-term concern (usually more than 100 occurrences) 
- 5: Demonstrably widespread, abundant, and secure.

Because the INL is located on BLM land, species of interest to the BLM were also considered. The BLM has five designations for these species, which include:

- $\quad$ Type 1-Threatened, Endangered, Proposed, and Candidate: Species listed by the FWS or National Oceanic and Atmospheric Administration Fisheries Service as threatened, endangered, proposed, or candidates for listing under the ESA of 1973.

- $\quad$ Type 2 - Rangewide/Globally Imperiled: Species experiencing significant declines throughout their range, with a high likelihood of being listed in the foreseeable future due to their rarity and/or significant endangerment factors.

- $\quad$ Type 3 - Regional/State Imperiled: Species experiencing significant declines in population or habitat and are in danger of regional or local extinctions (in Idaho) in the foreseeable future if factors contributing to their decline continues. This includes Idaho BLM sensitive species that (a) are not in Type 2, (b) have an S1 or S2 state rank (exception being a peripheral or disjunct species), or (c) score high (18 or greater) using the Criteria for Evaluating Animals for Sensitive Species Status, or (d) indicate significant declines in other regional/national status evaluations (e.g., Partners in Flight scores).

- $\quad$ Type 4 - Peripheral: Species generally rare in Idaho with the majority of their breeding range largely outside the state. This includes sensitive species that have an S1 or S2 state ranking but are peripheral species to Idaho.

- $\quad$ Type 5 - Watch List: These species are not considered BLM sensitive species, and associated sensitive species policy guidance does not apply. Watch list species include species that may be added to the sensitive species list depending on new information concerning threats, species' biology, or statewide trends. The Watch List includes species with insufficient data on population or habitat trends or threats that are poorly understood.

An information request was submitted to the Idaho Department of Fish and Game Conservation Data Center (CDC) requesting all known occurrences of sensitive species within the exterior boundaries of INL or within $5 \mathrm{mi}$ of the boundary. Seven fish, 1 amphibian, 6 reptiles, 25 birds, 28 mammals, 1 insect, and 7 plants were identified as sensitive species.

As noted in Appendix B (B-2.2.7 and B-3.4.3), no critical habitat is present on the INL and current CDC data (only the Environmental Surveillance, Education, and Research [ESER] INL Species List [INL ESER, 2009]) identify bull trout as a federally threatened species. None of the proposed facilities would be expected to impact fish habitat (the only site near potential fish habitat is Site 15, which is near the Big Lost River), and so fish species are not discussed further. Because there are no other ESA-listed species on the INL, no further discussion of federally-protected species is warranted.

The ecologically sensitive criterion evaluation considered State-listed species with ranks of S1, S2, or S3 and BLM species with ranks of Type 1, Type 2, or Type 3. The only S1 (no Type 1) species is the Idaho point-headed grasshopper (Acrolophitus pulchellus) and the sepal-tooth dodder (Cuscuta denticulate). The grasshopper is an Idaho endemic and is known to occur only in east-central Idaho in the Birch Creek and Big Lost River drainages. Very little is known about this species or its habitat requirements and the species may be extinct since it has not been positively identified in any study since 1993. The dodder is considered below with the other plant species. 
The remaining sensitive species (i.e., S2 or S3, Type 2, or Type 3) identified as occurring on or near INL included the following:

- $\quad$ Brewer's Sparrow (Spizella breweri) Ranking: G5, S3 (breeding), Type 3

- $\quad$ Ferruginous Hawk (Buteo regalis) Ranking: G4, S3 (breeding), Type 3

- $\quad$ Greater Sage Grouse (Centrocercus urophasianus) Ranking: G4, S2, Type 2

- $\quad$ Loggerhead Shrike (Lanius ludovicianus) Ranking: G4, S3

- $\quad$ Long-billed Curlew (Numenius americanus) Ranking: G5, S2 (breeding)

- $\quad$ Prairie Falcon (Falco mexicanus) Ranking: G5, S3 (nesting)

- Western Meadowlark (Sturnella neglecta) Ranking: G5, S3 (nesting)

- Idaho Pocket Gopher (Thomomys idahoensis) Ranking: G4, S3

- $\quad$ Merriam's Shrew (Sorex merriami) Ranking: G5, S2

- $\quad$ Piute Ground Squirrel (Spermophilus mollis) Ranking: G5, S2

- $\quad$ Pygmy Rabbit (Brachylagus idahoensis) Ranking: G4, S2, Type 2

- $\quad$ Townsend's Big-eared Bat (Corynorhinus townsendii) Ranking: G4, S3, Type 3

- $\quad$ Lost River Milkvetch (Astragalus amnis-amissi) Ranking: G3, S3, Type 3

- $\quad$ Lemhi Milkvetch (Astragalus aquilonius) Ranking: G3, S3, Type 2

- $\quad$ Plains Milkvetch (Astragalus gilviflorus) Ranking: G5, S2, Type 3

- Winged-seed Evening Primrose (Camissonia pterosperma) Ranking: G4, S2, Type 4

- $\quad$ Lichen (Catapyrenium congestum) Ranking: G4, S2, Type 4

- $\quad$ Sepal-tooth Dodder (Cuscuta denticulate) Ranking: G4, S1, Type 3

- $\quad$ Spreading Gilia (Ipomopsis polycladon) Ranking: G4, S2, Type 3.

All ecologically sensitive plants and animals were considered in the siting study. Some animal and plant species were given additional consideration in the siting study for reasons described below. The wildlife species considered most important for the evaluation and for which specific siting criteria were developed were the greater sage-grouse and pygmy rabbit, because they are currently being considered for listing under the ESA. Additional consideration was also given to raptors, which are protected under the Migratory Bird Treaty Act, and a siting criterion was developed for them. Sensitive plant species were also given additional consideration since they are not mobile and a siting criterion was developed for them. Figure C-20 presents a composite distribution of scoring zones for these species, including $1 / 2$-mile radius around known raptor sites and pygmy rabbit nesting areas, and location of sensitive plant species. 
The most current lek data included in Figure C-20 were obtained from Dr. R. Blew (Shurtliff and Whiting 2009). 


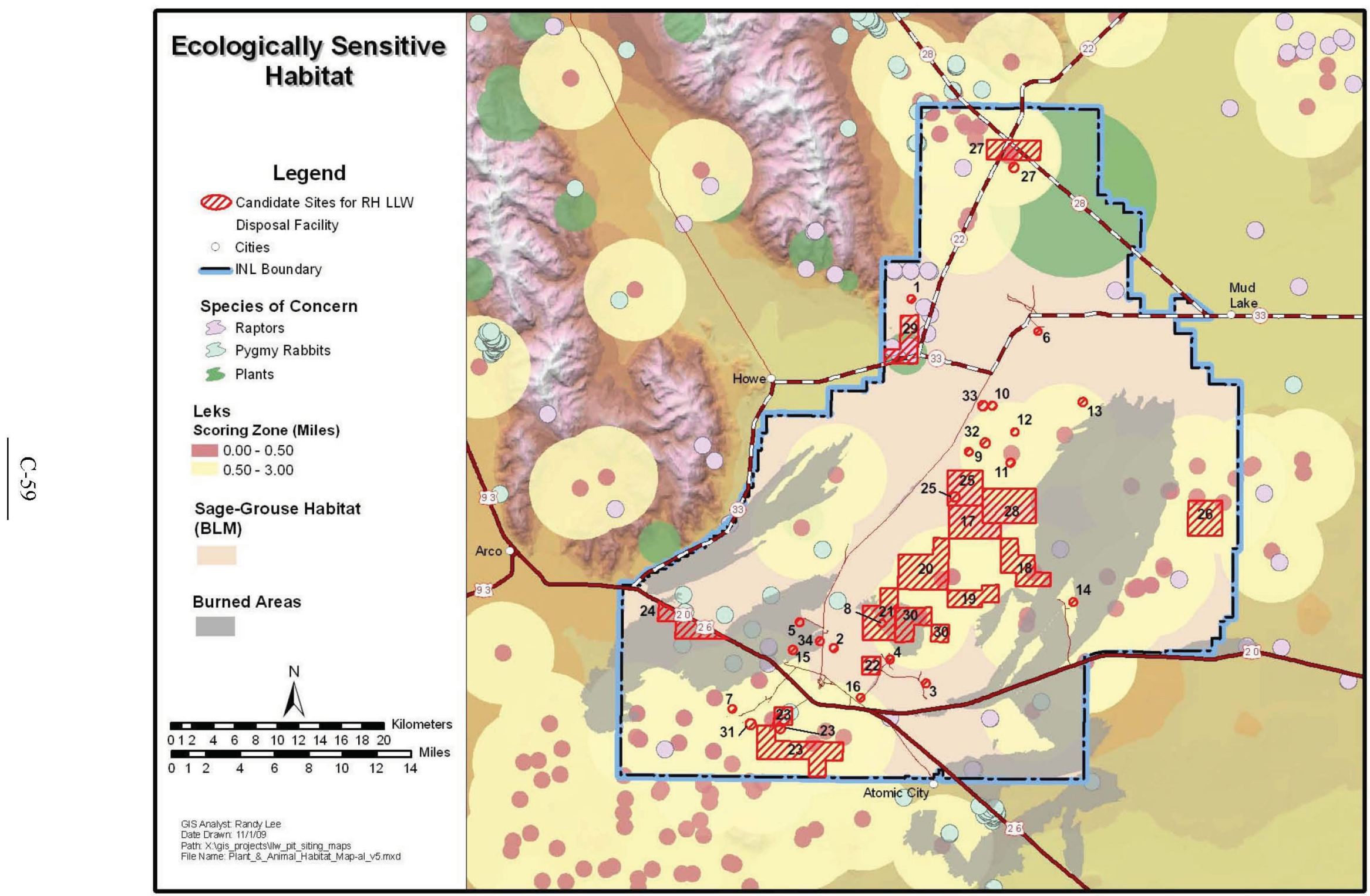

Figure C-20. Critical habitat. 
For greater sage grouse, both foraging and breeding/nesting/brood rearing habitat are important factors. Habitat considerations are largely included in the criterion related to locating a site within the core infrastructure area since habitat within these areas is already disturbed. Sage grouse use almost exclusively sagebrush habitat for all of their activities, so actions to limit further disturbance or fragmentation to this habitat is desired. Figure C-20 presents the extent of sage-grouse habitat (encompassing most of the INL), location of known lek sites and 3-mile scoring zone, and the composite extent of burned areas where sage-grouse and other habitat has been destroyed. A site located within a burned area was assigned a score of 5 . A site located within sage-grouse habitat but outside any lek scoring zone was assigned a score of 3 . A site located within a lek scoring zone or within an identified species of concern site for raptors, pygmy rabbits, or sensitive plants was assigned a score of 1 .

Sage grouse use almost exclusively sagebrush habitat for all of their activities. High quality sagebrush habitat for sage-grouse and for many of the sensitive species noted in this report, including those that are sagebrush-obligate species, is found throughout INL especially within the core infrastructure area. For breeding sage-grouse, the siting criteria used distance from known lek sites. Most desirable would be sites that were located at least $3 \mathrm{mi}$ or more from known leks. No specific criteria were developed for foraging and brood rearing habitat, but actions to limit further disturbance or fragmentation to sagebrush habitat is desired. Field surveys for habitat, leks, and other site-specific information would be collected as part of the NEPA phase of this project for each of the final sites under consideration for siting the LLW facility.

Sites $5,8,15$, and 34 were located within burned areas and were each assigned a score of 5 . Although site 24 was in proximity to several pygmy rabbit sites, it was also located within a burned zone and was also assigned a score of 5 . Sites 2, 3, 6, 10, 17, 21, 22, 25, 28, 30, and 33 were located within sage grouse habitat but away from lek scoring zones or raptor, pygmy rabbit, or sensitive plant sites and were each assigned a score of 3 (Table C-23). Sites 4, 7, 9, 10, 11 through 14, 16, 19 through 20, 26, 31, and 32 were located within 3 miles of a known lek and were each assigned a score of 1 . Site 18 was located within a lek scoring zone and a known raptor site and was assigned a score of 1 . Site 23 was located within a lek scoring zone and in proximity to a pygmy rabbit site and was assigned a score of 1.

Table C-23. Ecologically sensitive species and habitat.

\begin{tabular}{cll} 
Score & \multicolumn{1}{c}{ Sites } & \multicolumn{1}{c}{ Scoring Rationale } \\
\hline 5 & $5,8,15,24,34$ & Sites located within burned zones. \\
\hline 3 & $\begin{array}{l}2,3,6,10,17,21,22,25,28, \\
30,33\end{array}$ & $\begin{array}{l}\text { Sites located in sage-grouse habitat but outside known } \\
\text { lekking site 3-mile scoring zones. }\end{array}$ \\
\hline \multirow{3}{*}{$\begin{array}{l}4,7,9,11,12,13,14,16,18, \\
19,20,23,26,31,32\end{array}$} & $\begin{array}{l}\text { Sites located within 3 mi of known lekking sites, within } 1 / 2 \mathrm{mi} \\
\text { of known raptor nests or pygmy rabbit burrows, orlocated } \\
\text { within sensitive plants buffer zone. }\end{array}$ \\
\hline
\end{tabular}




\section{C-6. SUPPLEMENTAL DATA}

Six additional figures showing data that were not used in the siting evaluation are included for reference. The subject areas represented by these figures were not conducive to a numerical scoring system; however, they do provide additional information that others might wish to consider in weighing the pros and cons of the potential sites. The six figures are:

- $\quad$ Figure C-21, INL bedrock geology

- $\quad$ Figure C-22, INL groundwater elevation

- $\quad$ Figure $\mathrm{C}-23$, INL vegetation

- $\quad$ Figure C-24, INL wildland fires

- $\quad$ Figure C-25, INL political boundaries

- $\quad$ Figure C-26, INL population census blocks. 


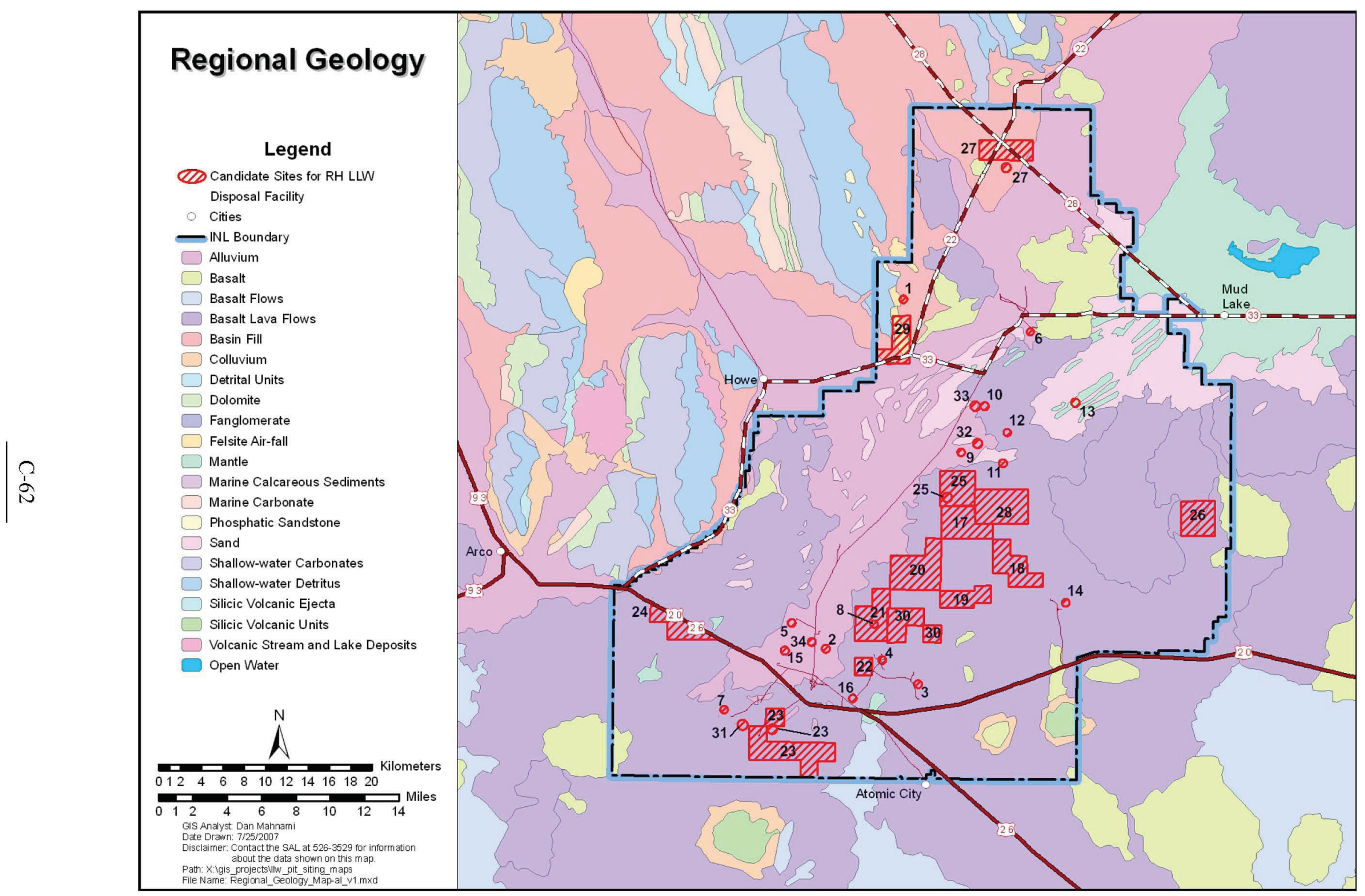

Figure C-21. Idaho National Laboratory regional geology. 


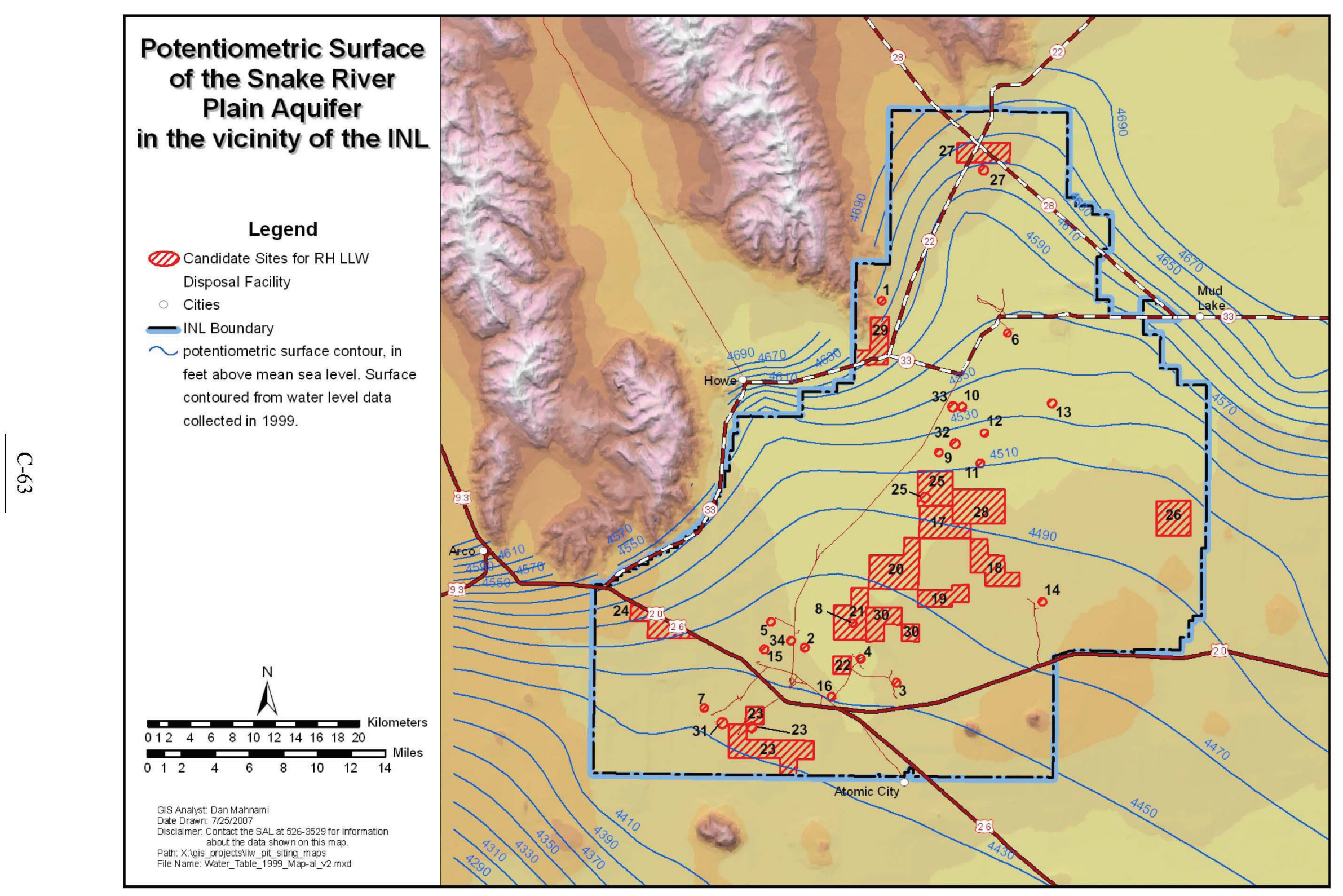

Figure C-22. Potentiometric surface of the Snake River Plain Aquifer in 1999 in the vicinity of the Idaho National Laboratory. 


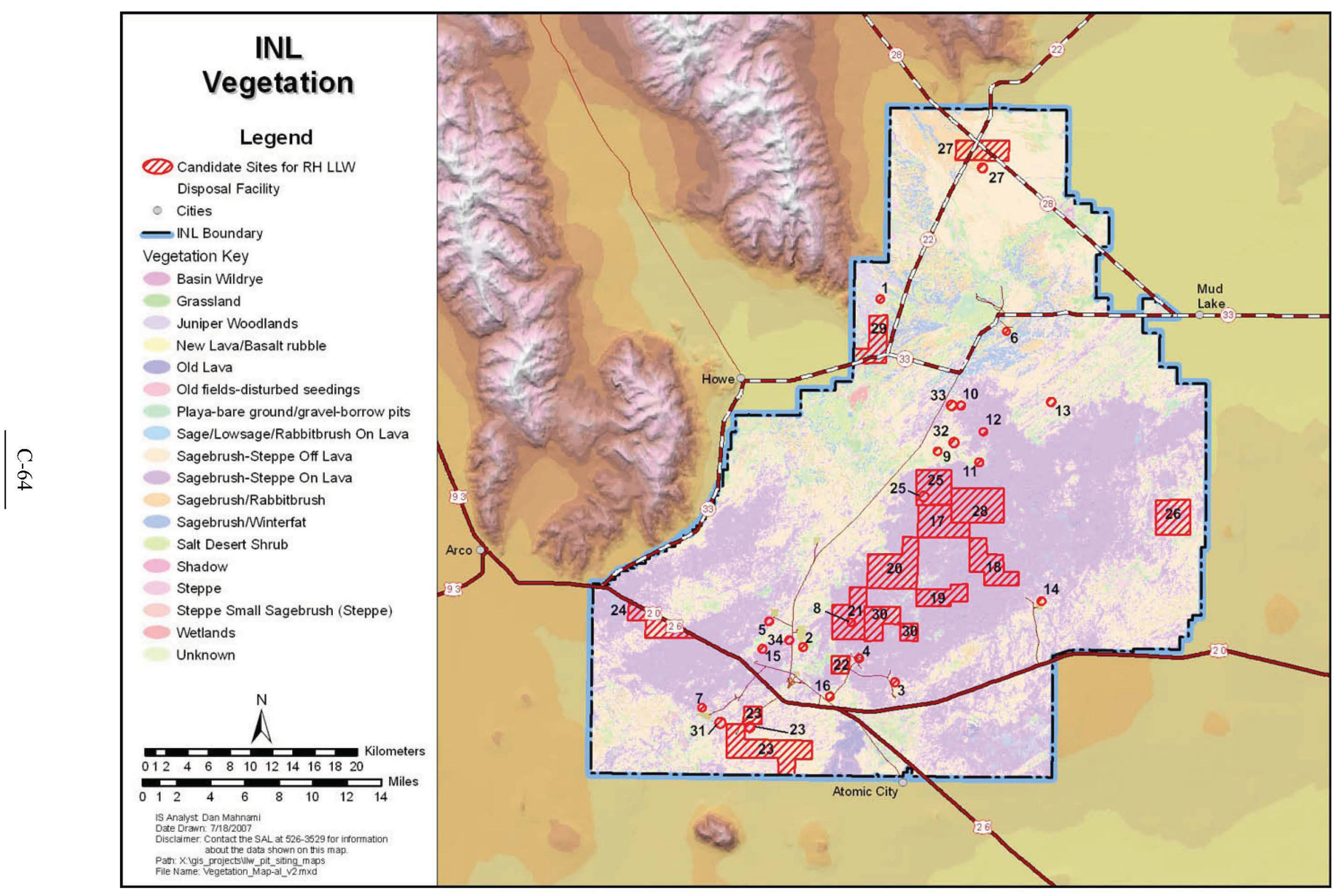

Figure C-23. Idaho National Laboratory vegetation. 


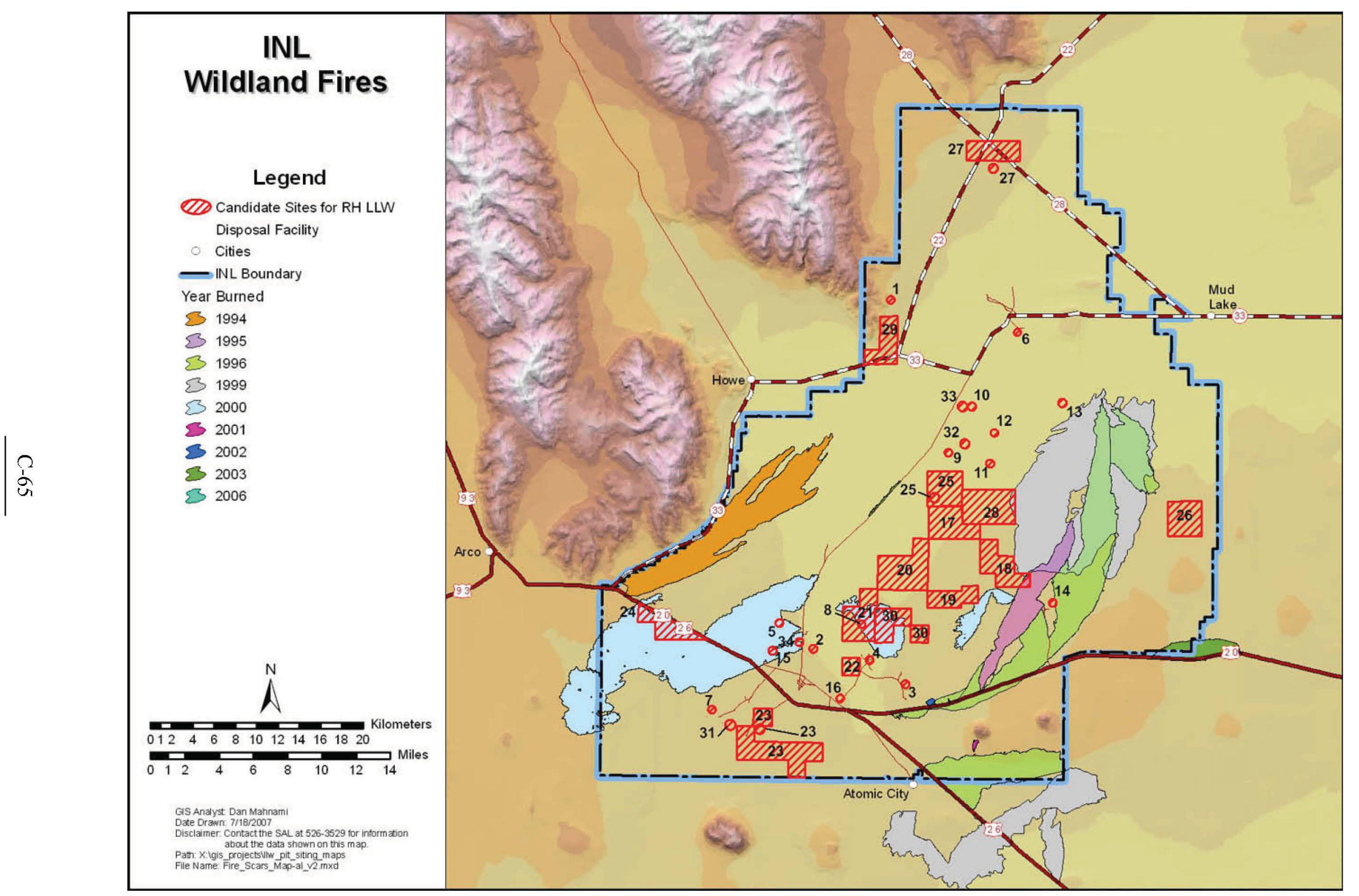

Figure C-24. Idaho National Laboratory wildland fires. 


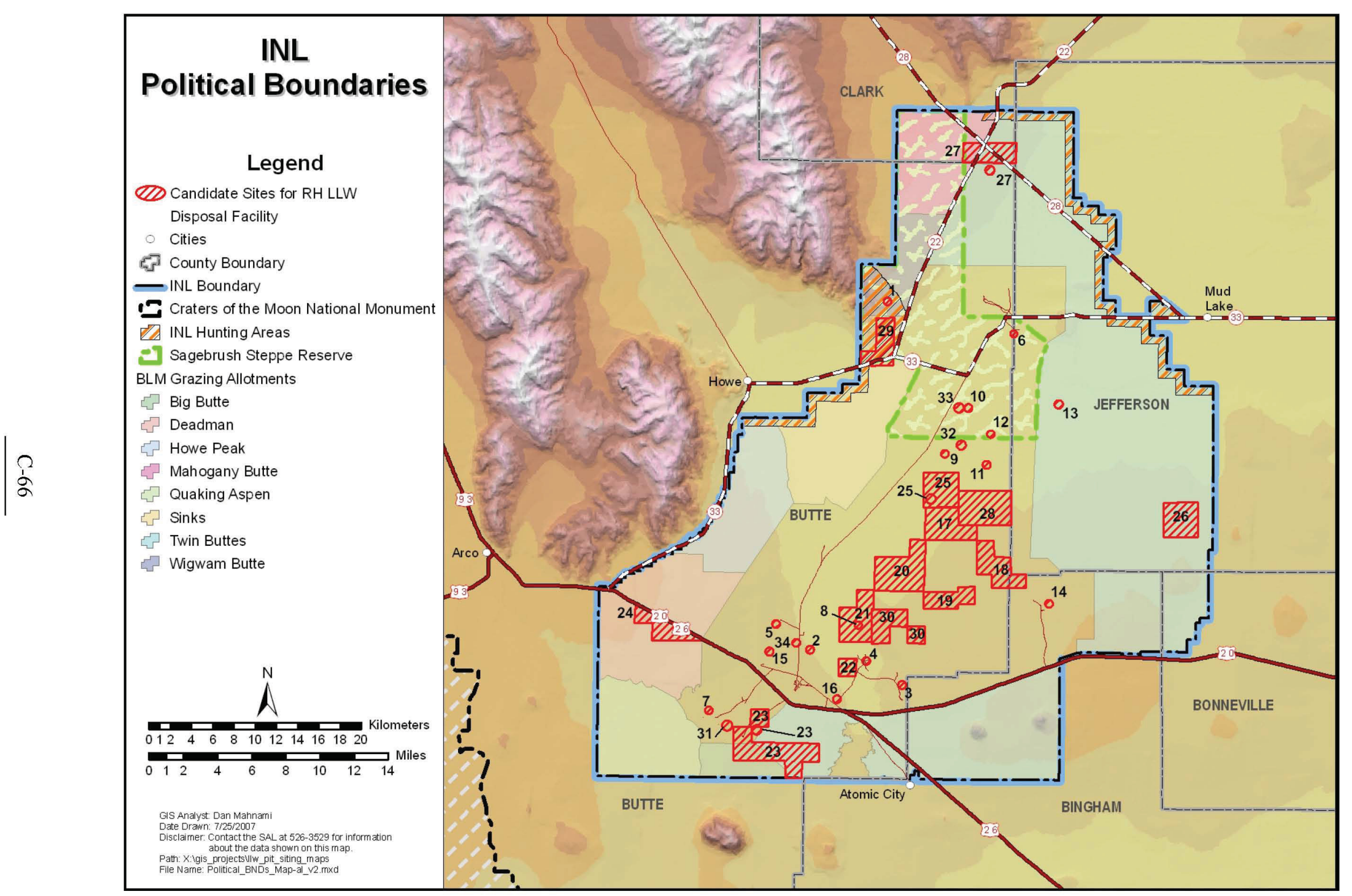

Figure C-25. Idaho National Laboratory political boundaries. 


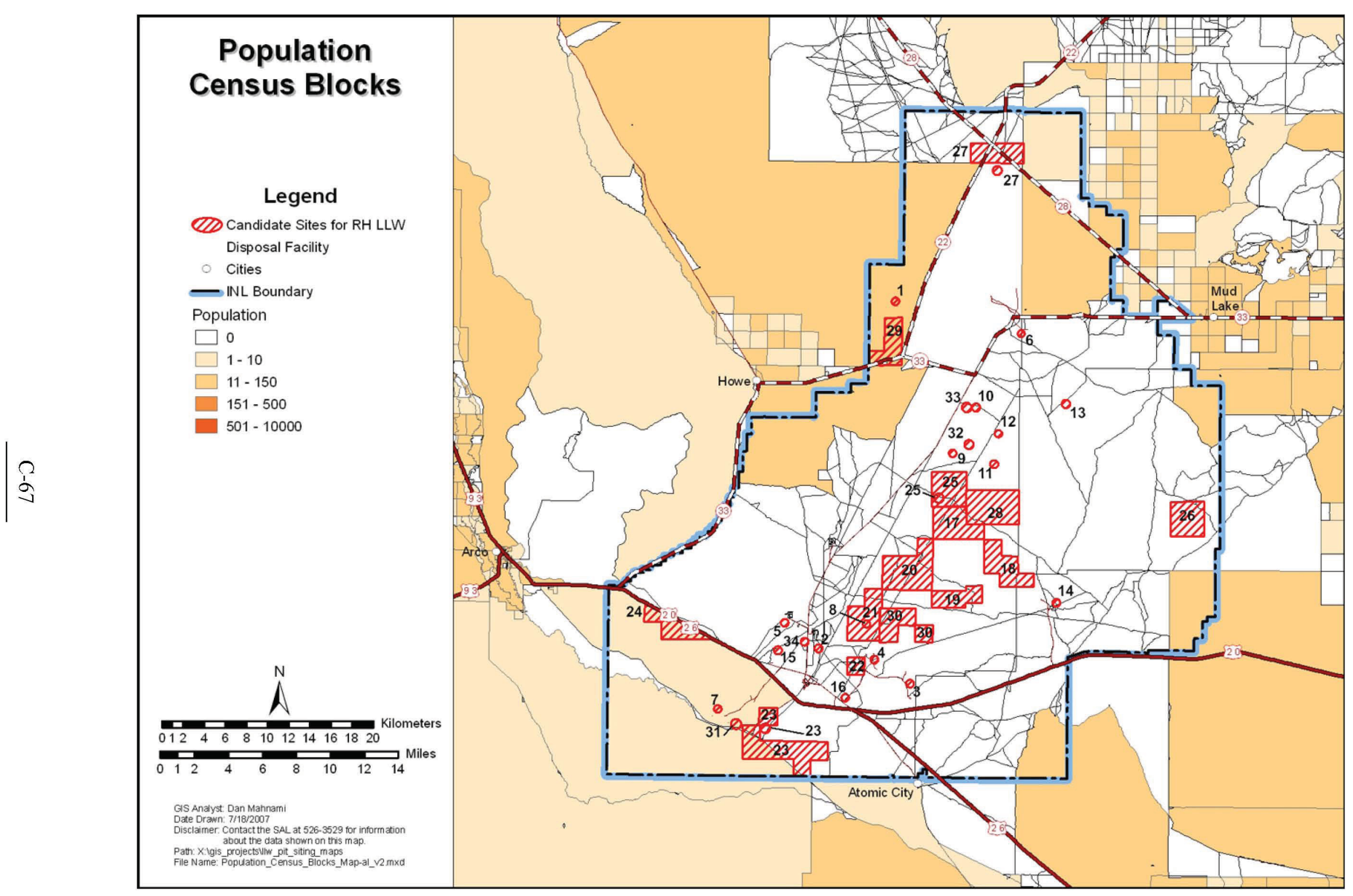

Figure C-26. Population census blocks. 


\section{C-7. REFERENCES}

Anderson, S.R., D.J. Ackerman, M.J. Liszewski, and R.M. Freiburger, 1996, Stratigraphic Data for Wells at and Near the Idaho National Engineering Laboratory, Idaho, U.S. Geological Survey OpenFile Report 96-248, 27 p, one diskette.

Anderson, S.R., M.J. Liszewski, and D.J. Ackerman, 1996, Thickness of Surficial Sediment at and Near the Idaho National Engineering Laboratory, Idaho, U.S. Geological Survey Open-File Report 96$330,16 \mathrm{p}$.

BLM, 2004, INEEL Sagebrush Steppe Ecosystem Reserve Final Management Plan, EA-ID-07402-067, U.S. Bureau of Land Management, Idaho Falls, Idaho.

Cahn, L.S., M.L. Abbott, J.F. Keck, P. Martian, A.L. Schafer, and M.C. Swenson, 2006, Operable Unit 3-14 Tank Farm Soil and Groundwater Remedial Investigation/Baseline Risk Assessment, DOE/NE-ID-11227.

DOE-ID, 2007, INL Annual Site Environmental Report, 2007, DOE/ID-12082(07), Prepared for the U.S. Department of Energy Idaho Operations Office by the S.M. Stoller Corporation, Environmental Surveillance Education and Research Program, 2007.

Hackett, W.R. R.P. Smith, and S. Khericha, 2002, Volcanic Hazards of the Idaho National Engineering and Environmental Laboratory, Southeast Idaho, in Tectonic and Magmatic Evolution of the Snake River Plain Volcanic Province, Idaho Geological Survey Bulletin 30, edited by B. Bonnichsen, C.M. White, and M. McCurry.

Hackett, W.R., J.A. Tullis, R.P. Smith, S.J. Miller, T.V. Dechert, P.A. McDaniel, and A.L. Falen, 1994, Geologic Processes in the RWMC, Idaho National Laboratory: Implications for Long Term Stability and Soil Erosion at the Radioactive Waste Management Complex, EGG-WM-111430, September 1994.

Holdren, K.J., J.D. Burgess, K.N. Keck, D.L. Lowrey, M.J. Rohe, R.P. Smith, C.S. Staley, and J. Banaee, 1997, Preliminary evaluation of potential locations on the Idaho National Engineering and Environmental Laboratory for a High-Level Waste Treatment and Interim Storage Facility and a Low-Level Waste Landfill, INEEL/EXT-97-01324.

IDFG, 2005, Idaho Comprehensive Wildlife Conservation Strategy. Idaho CDC, Idaho Fish and Game Department, Boise, ID. http://fishandgame.idaho.gov/cms/tech/CDC/cwes.cfm.

INL ESER, 2009, Idaho National Laboratory, Environmental Surveillance, Education and Research Program. 2009. INL Species List. http://www.stoller-eser.com/species index.htm.

Kostelnik, K.M., 2005, Idaho National Laboratory Comprehensive Land Use and Environmental Stewardship Report, INL/EXT-05-00726, Idaho National Laboratory, Idaho Falls, Idaho.

Leecaster, M.K., 2004, FY 2004 Geostatistical Modeling of Lithologic Characteristics in the RWMC for OU 7-13/14, ICP/EXT-4-00494.

Ostenaa, D.A., and D.R.H. O'Connell, 2005, Big Lost River Flood Hazard Study, Idaho National Laboratory, Idaho, in Reclamation, Managing Water in the West, Bureau of Reclamation Summary Report. 
Peterson, M.D., A.D. Frankel, S.C. Harmsen, C.S. Mueller, K.M. Haller, R.L. Wheeler, R.L. Wesson, Y.Zeng, O.S. Boyd, D.M. Perkins, N. Luco, E.H. Field, C.J. Wills, and K.S. Rukstales, 2008, Documentation for the 2008 Update of the United States National Seismic Hazard Maps, U.S. Geological Survey Open-File Report 2008-1128.

Sehlke, G. 2003. The Idaho National Engineering and Environmental Laboratory Source Water Assessment, INEEL/EXT-02-01474, Idaho National Engineering and Environmental Laboratory, Idaho Falls, Idaho.

Shurtliff, Q.R. and J.C. Whiting, 2009, Annual Report of Surveys for Historic Sage-Grouse Leks on the Idaho National Laboratory Site, STOLLER-ESER-124.

URS Greiner Woodward-Clyde Federal Services, Geomatrix Consultants, and Pacific Engineering and Analysis, 1999, Final Report: Development of design basis earthquake parameters for TMI-2 independent spent fuel storage installation at the INEEL, Bechtel BWXT Idaho, LLC, External Report INEEL/EXT-99-00619, November.

URS Greiner Woodward-Clyde Federal Services, Geomatrix Consultants, and Pacific Engineering and Analysis, 2000, Recomputation of the seismic hazard at the Idaho National Engineering and Environmental Laboratory, Bechtel BWXT Idaho, LLC, External Report INEEL/EXT-99-00786, February.

Wood, T.R., C.M. Helm-Clark, H. Huang, S. Magnuson, T. McLing, B. Orr, M.A. Plummer, R. Podgorney, M.S. Roddy, M.J. Rohe, and E. Whitmore, 2007, Operable Unidt 10-08 Development Report on the Idaho National Laboratory Sitewide Three-Dimensional Aquifer Model, INL/EXT07-13337, Idaho National Laboratory.

Woodward-Clyde Federal Services, Geomatrix Consultants, and Pacific Engineering and Analysis, 1996, Site-specific probabilistic seismic hazard analyses for the Idaho National Engineering Laboratory, Lockheed Idaho Technologies Company Technical Report INEL-95/0536, 2 volumes. 